UNIVERSIDADE DE SÃO PAULO

ESCOLA DE ENFERMAGEM DE RIBEIRÃO PRETO

María Alberta García Jiménez

LIDERANÇA DE ENFERMAGEM NAS ORGANIZAÇÕES DE SAÚDE DA CIDADE DO MÉXICO, DISTRITO FEDERAL

RIBEIRÃO PRETO - SP

2007 


\section{María Alberta García Jiménez}

\section{LIDERANÇA DE ENFERMAGEM NAS ORGANIZAÇÕES DE SAÚDE DA CIDADE DO MÉXICO, DISTRITO FEDERAL}

Tese apresentada ao Programa de Pós-Graduação em Enfermagem Fundamental do Departamento de Enfermagem Geral e Especializada da Escola de Enfermagem de Ribeirão Preto da Universidade de São Paulo, para obtenção do título de Doutor em Enfermagem.

Linha de pesquisa: Dinâmica da organização dos serviços de saúde e enfermagem.

Orientadora: $\mathrm{D}^{\text {ra }}$. Elizabeth Laus Ribas Gomes

RIBEIRÃO PRETO

2007 
Autorizo a reprodução e divulgação total ou parcial deste trabalho, por qualquer meio convencional ou eletrônica, para fins de estudo e pesquisa, desde que citada a fonte.

\section{FICHA CATALOGRÁFICA}

García-Jiménez, María Alberta

Liderança de enfermagem nas organizações de saúde da cidade do México, Distrito Federal. / María Alberta García Jiménez; Orientadora Elizabeth Laus Ribas Gomes. Ribeirão Preto, 2007. $201 \mathrm{f}$; $30 \mathrm{~cm}$.

Tese apresentada ao Programa de Pós-Graduação em Enfermagem Fundamental do Departamento de Enfermagem Geral e Especializada da Escola de Enfermagem de Ribeirão Preto da Universidade de São Paulo, para obtenção do título de Doutor em Enfermagem.

1. Liderança; 2. Organização e Administração; 3. Hospital. 
A tese ora apresentada é resultado do convenio celebrado entre a Universidade de São Paulo, com interveniência da Escola de Enfermagem de Ribeirão Preto e a Universidade de Guanajuato-México, através da Faculdade de Enfermagem e obstetrícia de Celaya. 


\section{FOLHA DE APROVACÃO}

\section{María Alberta García Jiménez.}

Titulo: Liderança de enfermagem nas organizações de saúde da cidade do México, Distrito Federal

Tese apresentada ao Programa de Pós-Graduação Enfermagem fundamental da Escola de Enfermagem de Ribeirão Preto da Universidade de São Paulo, para obtenção do título de Doutor em Enfermagem. Inserida na linha de pesquisa enfermagem: Dinâmica da organização dos serviços de saúde e enfermagem.

Área de concentração: Enfermagem Fundamental.

Aprovada em:

\section{Banca Examinadora}

Prof. Dr.

Institução: Assinatura:

Prof. Dr.

Institução: Assinatura:

Prof. Dr.

Institução: Assinatura:

Prof. Dr.

Institução: Assinatura:

Prof. Dr.

Institução: Assinatura: 


\section{Dedicatória}

A Deus, fonte inesgotável de sabedoria e proteção. Que por amor, tornou possível o final de esta etapa que, hoje, se materializa no legado da minha contribuição dos conhecimentos da humanidade.

A meus pais e irmãos, por poder contar com o seu apoio e confiança.

A você Gabriel por ter acreditado e confiado em mim, pelo o apoio incondicional, pela compreensão, incentivo e tolerância. 


\section{Agradecimentos}

Às autoridades da Universidade Autônoma Metropolitana do México, pela oportunidade de dar continuidade ao meu desenvolvimento Professional.

À Dra. Maria Elena Espino Villafuerte por ser uma pessoa visionaria, que na procura de contribuir com o desenvolvimento da enfermagem Mexicana, projetou o convênio para a formação de doutores.

Às autoridades da Faculdade de Enfermagem e Obstetrícia de Celaya Guanajuato pelas atenções e concessões recebidas durante a realização deste estudo.

À Dra. Elizabeth Laus Ribas Gomes por compartilhar seus conhecimentos, apoio acadêmico e moral na realização deste estudo, no Brasil.

O Dr. Gabriel Moreno Farias professor da Universidade Nacional Autônoma de México, pelo apoio acadêmico, na minha trajetória acadêmica.

Aos Professores da banca examinadora pelas sugestões e contribuições no estudo e na minha formação e desenvolvimento, dentro da área cientifica.

Às funcionarias Idamara e Kethleen pela compreensão e força na adaptação à cultura brasileira deste belo país.

Às Autoridades do Programa de "Mejoramiento del Profesorado" (PROMEP), organização pública do México, pelo incentivo financeiro.

À Dra. Maria Cecília Puntel de Almeida, pelo apoio recebido em todo momento como autoridade e como pessoa. Sempre ficarei muito obrigada!

Às autoridades da Secretaría de Salud de México e diretoras de enfermagem pela participação e importantes contribuições no estudo. Um agradecimento especial para a Licenciada Juana Jiménez.

A meus companheiros mexicanos, pelo respeito e tolerância, assim como, pelo apoio no meu desenvolvimento profissional e pessoal. Agradeço de maneira especial aos meus amigos: Maria Elena, Karla, Paco, Elizabeth, Lety, Lupita, Carmelita e Gloria. Obrigada pela força!

A todos os que colaboraram deste trabalho, direta ou indiretamente, seja com sua colaboração ou com sua amizade e pelo apoio, muito obrigada. 


\section{Resumo}

GARCÍA-JIMÉNEZ, M.A. Liderança de enfermagem nas organizações de saúde da Cidade do México, Distrito Federal. 2007. 201 f. Tese (Doutorado) - Escola de Enfermagem de Ribeirão Preto, Universidade de São Paulo, Ribeirão Preto, 2007.

O estudo teve como objetivo identificar os estilos de liderança exercidos pelos profissionais de enfermagem com cargos diretivos e sua relação com os traços de conduta tipo A e a maturidade dos colaboradores sob sua direção. $\mathrm{O}$ universo esteve composto por enfermeiros diretivos de cinqüenta hospitais gerais da cidade de México, Distrito Federal, sendo tomado como referencial teórico o modelo de liderança situacional de Hersey e Blanchard e a Teoria de Conduta de Friedman e Rosenman. Foi testada a hipótese de relação significante entre os estilos de liderança exercidos pelos profissionais com cargos diretivos e seus traços de conduta tipo A e os tipos de maturidade de seus colaboradores. O estudo é de caráter quanti-qualitativo. Os resultados quantitativos mostraram que os profissionais com cargos diretivos exercem diferentes estilos de liderança. Os valores de correlações foram $\mathrm{S} 1 \mathrm{R}^{2} 0,14$ dos profissionais exercem a liderança diretiva (alta preferência pelas tarefas e baixa preferência pelas relações interpessoais), S2 $\mathrm{R}^{2}$ 0,59 o estilo persuasivo (alta preferência pelas tarefas e alta preferência pelas relações interpessoais), S3 $\mathrm{R}^{2}$ 0,27 o estilo participativo (alta preferência pelas relações interpessoais e baixa preferência pelas tarefas) e S4 $\mathrm{R}^{2} 0,21$ o estilo delegativo (baixa preferência pelas tarefas e baixa preferência pelas relações interpessoais). A maturidade inativa, foi observado um coeficiente de correlação de R1 R $\mathrm{R}^{2} 0.14$ dos participantes (baixa disposição e baixa habilidade para as tarefas); $\mathrm{R} 2 \mathrm{R}^{2} 0,51$ apresentou maturidade reativa (baixa disposição e alta habilidade para as tarefas), $\mathrm{R} 3 \mathrm{R}^{2} 0,18$ maturidade pró-ativa (alta disposição e baixa habilidade para as tarefas) e R4 $\mathrm{R}^{2}$ 0,14 a maturidade interativa (alta disposição e alta habilidade para as tarefas). Em uma escada de 0 a1, a qualificação media para os traços conduta tipo A mostraram Os $74 \%$ dos profissionais com cargos diretivos. Os resultados qualitativos indicam que esses profissionais percebem um ambiente de trabalho burocrático, com características típicas de organização e regulamentação, comunicação, e hierarquia orientada ao alcance dos objetivos. O alto grau de exigência é observado na sobrecarga de trabalho, o $81 \%$ dos diretivos cumprem com jornadas de trabalho diário de mais oito horas e $64 \%$ desses diretivos têm sob sua responsabilidade entre 400 e 500 trabalhadores. Outro indicador qualitativo é o período de permanência no cargo diretivo, variando entre um a dez anos para os $81 \%$, e a tendência à continuidade do preparo acadêmico: $62 \%$ com grau de licenciatura e $24 \%$ com pós-graduação. Conclui-se que os diretivos alcançam as metas propostas com diferentes estilos de liderança que visam a estimular os enfermeiros, que mostram estar preparados, mas com problemas de motivação. Os diretivos utilizam estratégias de persuasão para obter a colaboração dos seguidores. Na situação analisada, se cumpre o modelo Hersey e Blanchard e oferece importantes pontos de vista para o fortalecimento da liderança em enfermagem nos hospitais gerais da cidade de México, Distrito Federal.

Descritores: Liderança; Organização e Administração; Hospital. 


\begin{abstract}
GARCÍA-JIMÉNEZ, M. A. Leadership in nursing in health institutions of México city, México. 2007. 201 p. Doctoral Dissertation - University of São Paulo at Ribeirão Preto Collegue of Nursing, Ribeirão Preto, 2007.
\end{abstract}

The main objective of this study is identify the styles of leadership exercised by directive nurses at general hospitals of Mexico City, according to situational leadership model of Hersey and Blanchard and its relationship with features type "A" of the leaders and the degrees of the maturity of their collaborators, according to behavior theory of Friedman and Rosenman. The study is quant-qualitative and was done with cooperation of directive nurses at the mentioned hospitals. The quantitative results demonstrated four leadership styles exercised by directive nurses: directive style characterized by its high preference for the tasks and low preference for the interpersonal relationships, persuasive style characterized by its high preference for the tasks and high preference for the interpersonal relationships, participant style characterized by its high preference for the relationships interpersonal and low preference for the tasks and delegatory style characterized by low preference for the tasks and low preference for the interpersonal relationships. The directive nurses apply the directive style in coefficient determination $R^{2} 0,14$ of their decisions, the persuasive style in $\mathrm{R}^{2} 0,59$, the participant style in $\mathrm{R}^{2} 0,27$ and the delegatory style in $\mathrm{R}^{2} 0,21$ of their decisions. The followers showed four grades of readiness for the execution of their tasks: coefficient determination, inactive $\mathrm{R}^{2} 0,14$ attitude characterized by their low disposition and low ability for the tasks, reactive $\mathrm{R}^{2} 0,51$ attitude characterized by its low disposition and high ability for the tasks, attitude pre-active $\mathrm{R}^{2} 0,18$ characterized by its high disposition and low ability for the tasks and interactive $\mathrm{R}^{2} 0,14$ attitude characterized by its high disposition and high ability for the tasks. The directive nurses showed features of behavior type $\mathrm{A}$ in $74 \%$ of the cases. The qualitative results indicate that the directive ones perceive a mechanicbureaucratic orientation of the hospitals, with their typical characteristics of norms, communication, functions and hierarchy, total orientation to the achievement of the objectives, emphasis in the tasks and routine processes. The high demand is reflected in the work overload that they experience. In $81 \%$ of cases they work more than eight daily hours, $64 \%$ supervises between 400 and 500 professionals of the health and $81 \%$ abandon their positions after 10 years. The directive personnel has tendency toward the academic advance. $62 \%$ has degree grade and $24 \%$ has postgraduate. The directive nurses achieve the goals of the organization by means of the combination of four styles of leadership to influence in their followers; most of them are well qualified but have motivation problems. The directive nurses apply, frequently, the persuasive style of leadership which is related with the reactive attitude of the followers. They solve the personnel's deficiencies with excessive work loads. To conclude, the pattern of situational leadership of Hersey and Blanchard is useful to diagnose the situation of the leadership of the nurses and to identify the aspects to be strengthened in the general hospitals of the city of Mexico D. F.

Key words: Leadership; Organization and Management; Hospital. 


\section{Resumen}

GARCÍA-JIMÉNEZ, M. A. Liderazgo de enfermería en las organizaciones de salud de la Ciudad de México, Distrito Federal. 2007. 201 p. Tesis (Doctorado) - Escuela de Enfermería de Ribeirão Preto, Universidad de São Paulo, 2007.

El estudio tuvo por objetivo identificar los estilos de liderazgo ejercido por directivos de enfermería, su relación con rasgos de conducta tipo A y la madurez de colaboradores a su cargo, en cincuenta hospitales generales de la ciudad de México D. F. con base en el modelo de liderazgo situacional de Hersey y Blanchard y teoría de la conducta de Friedman y Rosenman. Se partió de la hipótesis que hay relación significativa de los estilos de liderazgo ejercidos por los directivos de enfermería con sus rasgos de conducta tipo A y los grados de madurez de sus colabores. El estudio fue cuanti-cualitativo. Los sujetos de estudio fueron directivos de enfermería con previo consentimiento. Los resultados cuantitativos demostraron que los directivos ejercen diferentes estilos de liderazgo con el análisis de regresión múltiple se obtuvieron los siguientes coeficientes de determinación: $\mathrm{R}^{2} 0.14$ para el estilo de liderazgo directivo (alta preferencia por las tareas y baja preferencia por las relaciones interpersonales) el $\mathrm{R}^{2}$ 0,59, para el estilo persuasivo (alta preferencia por las tareas y alta preferencia por las relaciones interpersonales), el $\mathrm{R}^{2} 0,27$ para estilo participativo (alta preferencia por las relaciones interpersonales y baja preferencia por las tareas) y el $\mathrm{R}^{2} 0,21$ fue para el estilo delegatorio (baja preferencia por las tareas y baja preferencia por las relaciones interpersonales). La madurez de los seguidores: el inactivo se encontró con coeficientes de determinación de $\mathrm{R}^{2} 0,14$ (baja disposición y baja habilidad para las tareas); el reactivo el $\mathrm{R}^{2} 0,51$ (baja disposición y alta habilidad para las tareas), el preactivo el $\mathrm{R}^{2} 0,18$ (alta disposición y baja habilidad para las tareas) y el interactivo $\mathrm{R}^{2} 0,14$ (alta disposición y alta habilidad para las tareas). Se encontraron rasgos de conducta tipo A en un $74 \%$ de los casos. Los resultados cualitativos indican que los directivos perciben un ambiente laboral burocrático, con sus características típicas de normatividad, comunicación y jerarquía, con plena orientación al logro de los objetivos. El alto grado de exigencia se refleja en la sobrecarga de trabajo que experimentan, el $81 \%$ tienen jornadas de más de ocho horas, el $64 \%$ de los directivos tienen a su cargo entre 400 y 500 profesionales. La perseverancia de los directivos en sus cargos, $81 \%$ entre 1 a 10 años. Los directivos manifiestan tendencia a la superación académica, el $62 \%$ tiene grado de licenciatura y el $24 \%$ tiene postgrado. Se concluye existe correlación entre las variables y que los directivos logran las metas impuestas mediante la combinación de estilos de liderazgo para dinamizar a su personal que en su mayoría está bien capacitado sus colaboradores que reflejan diferentes grados de madurez, los directivo recurre a la persuasión para lograr la colaboración. El modelo Hersey y Blanchard se cumple en la situación analizada y los rasgos de conducta tipo A están presentes, este estudio da excelentes puntos de análisis para fortalecer el liderazgo de enfermería en los hospitales generales de la ciudad de México D. F.

Descriptores: Liderazgo; Organización y Administración; Hospital. 


\section{Lista de Figuras}

Figura 1 - Relação entre os estilos de liderança e maturidade dos seguidores $\quad 87$

Figura 2 - Hipótese geral 110

Figura 3 - Delimitação geográfica por delegação política Distrito Federal 115

Figura 4 - Resultados da verificação das hipóteses do Grupo 1

Figura 5 - Resultados da verificação das hipóteses do Grupo 2

Figura 6 - Resultados da verificação das hipóteses do Grupo $3 \quad 144$

Figura 7 - Resultados da verificação das hipóteses do Grupo $4 \quad 145$

Figura 8 - Gráfico do período de permanência no cargo dirigente de Enfermagem nos hospitais gerais da cidade do México, D. F.

Figura 9 - Gráfico de distribuição segunda jornada de trabalho diária no desempenho do cargo

Figura 10 - Gráfico de distribuição do número de enfermeiros sob a responsabilidade do dirigente.

Figura 11 - Gráfico de distribuição do grau de escolaridade dos enfermeiros dos hospitais gerais do México, D. F 


\section{Lista de Quadros}

Quadro 1- Graus de maturidade e situação de seus componentes $\quad 91$

Quadro 2 - $\quad$ Estilo de liderança Instrutivo - S1 94

Quadro 3 - Estilo de liderança Persuasivo - S2 95

Quadro 4 - Estilo de liderança Participativo - S3 95

Quadro 5 - $\quad$ Estilo de liderança Delegatorio - S4 96

Quadro 6 - Estilos de liderança apropriados aos graus de maturidade 96

Quadro 7 - Grau de maturidade ou probabilidade de êxito dos estilos de

$\begin{array}{ll}\text { liderança } & 97\end{array}$

$\begin{array}{lll}\text { Quadro } 8 & \text { Resultados da verificação das hipóteses } & 146\end{array}$

$\begin{array}{lll}\text { Quadro } 9 & \text { Hipóteses alternativas aceitas } & 146\end{array}$

Quadro 10 - Apresentação dos elementos coincidentes em relação com as respostas dos sujeitos entrevistados 


\section{Lista de Tabelas}

Tabela 1 - Profissionais de enfermagem designados às organizações do sistema de saúde do Distrito Federal (SSDF)

Tabela 2 - Distribuição dos hospitais gerais da Cidade de México, Distrito Federal. 116

Tabela 3 - Escala de ponderação dos coeficientes 


\section{LISTA DE SIGLAS}

\begin{tabular}{|c|c|}
\hline APT & Atención Primaria de Salud \\
\hline CABEME & Catalogo de Beneficios Médicos \\
\hline CASE & Catalogo de Servicio \\
\hline CIE & Consejo Internacional de Enfermeras \\
\hline CIFHRS & $\begin{array}{l}\text { Comisión Interinstitucional para la Formación de Recursos } \\
\text { Humanos en Salud }\end{array}$ \\
\hline CNE & Colegio Nacional de Enfermería \\
\hline CABEME & Catalogo de Beneficio Médico \\
\hline COIE & Comisión Interinstitucional de Enfermería \\
\hline COMACE & Consejo Mexicano de Acreditación y Certificación en Enfermería \\
\hline COMLE & Colegio Mexicano de Licenciados en Enfermería \\
\hline CONACYT & Consejo Nacional de Ciencia y Tecnología \\
\hline CONEM & Colégio Nacional de Enfermeras Militares \\
\hline CSP & Comité de Servicios Profesionales \\
\hline D O & Diario Oficial \\
\hline FEMAFEE & $\begin{array}{l}\text { Federación Mexicana de Asociaciones de Facultades y Escuelas de } \\
\text { Enfermería }\end{array}$ \\
\hline GATT & Acuerdo General de Tarifas y Aranceles \\
\hline IMSS & Instituto Mexicano del Seguro Social \\
\hline INEG| & Instituto Nacional de Estadística Geografía e Informática \\
\hline INSALUD & Institutos Nacionales de Salud \\
\hline IPN & Instituto Politécnico Nacional \\
\hline ISES & Institución de Seguridad Especializada en Salud \\
\hline ISES & Instituciones de Seguros Especializadas en Salud \\
\hline ISSFAM & Instituto de Seguridad Social de la familia \\
\hline ISSSTE & Instituto de Seguridad y Servicio Social para los \\
\hline OMS & Organización Mundial de la Salud \\
\hline PEMEX & Petróleos Mexicanos \\
\hline PNS & Plan Nacional de Salud \\
\hline SEDENA & Secretaría de la Defensa Nacional \\
\hline SEMARNA & Secretaría de la Marina Nacional \\
\hline SEP & Secretaria de Educación Pública \\
\hline SIARHE & Sistema de Administración de Recursos Humanos en Enfermería \\
\hline SNS & Sistema Nacional de Salud \\
\hline SPS & Seguro Popular de Salud \\
\hline SS & Secretaría de Salud \\
\hline SSA & Secretaría de Salubridad y Asistencia \\
\hline SSDF & $\begin{array}{l}\text { Secretaría de Salud del Distrito Federal } \\
\text { Trabajadores del Estado }\end{array}$ \\
\hline UNAM & ma de Méxic \\
\hline
\end{tabular}




\section{Sumário}

RESUMO

ABSTRACT

RESUMEN

FIGURAS

QUADROS

TABELAS

LISTA DE SIGLAS

APRESENTAÇÃO 18

1 CONSTRUÇÃO DO APORTE TEÓRICO 26

1.1 SISTEMA NACIONAL DE SAÚDE DO MÉXICO (SNS) 27

$\begin{array}{ll}\text { 1.1.1 Origem do Sistema Nacional de Saúde } & 28\end{array}$

$\begin{array}{ll}\text { 1.1.2 Políticas de saúde } & 30\end{array}$

$\begin{array}{ll}\text { 1.1.3 Cobertura de atendimento para os mexicanos } & 32\end{array}$

$\begin{array}{ll}\text { 1.1.4 Reflexão do SNS } & 35\end{array}$

1.1.5 Secretaria de Saúde do Governo do Distrito Federal (SSDF) 39

1.1.6 Enfermagem no Sistema Nacional de Saúde (SNS) 43

1.2 OS HOSPITAIS COMO ORGANIZAÇÕES BUROCRÁTICAS: AMBIENTE DE TRABALHO DA ENFERMAGEM

1.2.1 Evolução da organização hospitalar $\quad 45$

1.2.2 Modelo burocrático do hospital $\quad 56$

1.2.3 Características de orientação burocrática nos hospitais 60

1.3 A ENFERMAGEM NO MÉXICO 62

1.3.1 A formação em Enfermagem $\quad 63$

$\begin{array}{ll}\text { 1.3.2 Evolução da Enfermagem do México } & 67\end{array}$

$\begin{array}{ll}\text { 1.3.3 A prática social de enfermagem } & 68\end{array}$

$\begin{array}{ll}\text { 1.3.3.1 Enfermagem no hospital geral } & 74\end{array}$

1.4 A LIDERANÇA EM ENFERMAGEM 77

$\begin{array}{ll}\text { 1.4.1 Conceito de liderança } & 79\end{array}$

1.4.2 Enfoques e teorias de liderança $\quad 83$

1.4.3 A teoria de Liderança Situacional de Hersey e Blanchard 84

1.4.4 A liderança em enfermagem 99

$\begin{array}{ll}\text { 1.4.5. Conduta tipo A do líder } & 105\end{array}$ 
2.1 Formulação das questões de pesquisa 108

$\begin{array}{lr}2.2 \text { Os objetivos } & 109\end{array}$

$\begin{array}{ll}2.3 \text { Hipótese geral } & 110\end{array}$

3 TRAJETÓRIA METODOLÓGICA 113

$\begin{array}{ll}3.1 \text { Tipo de estudo } & 114 \\ 3.2 \text { Campo do estudo } & 114\end{array}$

$\begin{array}{ll}3.2 \text { Campo do estudo } & 114\end{array}$

$\begin{array}{ll}3.3 \text { Definição do universo empírico } & 116\end{array}$

$\begin{array}{ll}3.4 \text { Sujeitos de estudo } & 116\end{array}$

$\begin{array}{ll}3.5 \text { Considerações Bioéticas } & 117\end{array}$

$\begin{array}{ll}3.6 \text { Etapas para a coleta dos dados } & 118\end{array}$

$\begin{array}{ll}3.7 \text { Análises dos dados } & 120\end{array}$

$\begin{array}{ll}\text { 3.7.1 Processamento dos dados } & 121\end{array}$

4 ANÁLISE DOS RESULTADOS E DISCUSSAO 122

$\begin{array}{ll}\text { 4.1 Comprovação da hipótese } & 124\end{array}$

4.1.1 Modelo matemático geral para as hipóteses do Grupo $1 \quad 124$

4.1.2 Modelo matemático geral para as hipóteses do Grupo 2 129

4.1.3 Modelo matemático geral para as hipóteses do Grupo $3 \quad 134$

4.1.4 Modelo matemático geral para as hipóteses do Grupo $4 \quad 138$

4.2 Resume de verificação das hipóteses 142

4.3 Análise de resultados das correlações dos estilos de liderança 146

$\begin{array}{ll}\text { 4.3.1 Explicações dos estilos de liderança do Grupo } 1 & 147\end{array}$

4.3.2 Explicações dos estilos de liderança do Grupo 2

4.3.3 Explicações dos estilos de liderança do Grupo $3 \quad 150$

4.3.4 Explicações dos estilos de liderança do Grupo 4

4.4 Análises dos dados de identidade $\quad 151$

4.5. Descrição das respostas das entrevistas semi-estruturadas 156

5 CONSIDERAÇÕES FINAIS 165

6 REFERÊNCIAS $\quad 170$

7 APÊNDICES 180

- Apêndice A Questionário estilos da liderança 181 
- Apêndice B Questionário de maturidade dos seguidores

- Apêndice C Questionário traços de conduta tipo A do diretivo 189

- Apêndice D Entrevista semi-estruturada 191

- Apêndice E Termo de consentimento livre e esclarecido 192

- Apêndice F Entrevistas em Espanhol 194

8 ANEXO 200

- Ditame do comitê de Bioética, da Faculdade de Enfermagem e Obstetrícia da Universidade de Guanajuato do México 
O presente estudo é resultado de experiências e observações vividas durante o exercício profissional, na direção da enfermagem, durante vinte e cinco anos, em diferentes cargos, no sistema de saúde mexicano, assim como, no exercício da docência da disciplina de Administração em Enfermagem. Essas experiências profissionais permitiram o conhecimento de atividades e ações desenvolvidas pelos lideres e os dirigentes de enfermagem, ambos com desempenho de papeis diferentes, porém, na compreensão da pratica e visando a melhores resultados do exercício da liderança, devem ser considerados como binômio. A oportunidade de participar, em qualidade de aluna de Doutorado de Enfermagem, do convenio celebrado entre a Universidade de São Paulo, com interveniência da Escola de Enfermagem de Ribeirão Preto e a Universidade de Guanajuato - México, através da Faculdade de Enfermagem e Obstetrícia de Celaya, para aprofundar o conhecimento sobre este fenômeno, que tem sido pouco estudado no campo da Enfermagem mexicana.

A liderança é um tema relevante no cenário dos diferentes grupos de pessoas e, para a enfermagem, seu exercício nas organizações, é de alta transcendência na tomada de decisões para o desenvolvimento da profissão em todos os campos da vida social, econômica e política. Este cenário despertou meu interesse, como administradora e como professora de enfermagem, para realizar estudos relacionados e contribuir com o desenvolvimento da Enfermagem mexicana e contribuir a melhora da atenção de enfermagem, favorecendo o bem-estar da população Mexicana.

O novo paradigma das organizações encontra-se distante do equilíbrio em que coexistem a instabilidade, a tensão, o conflito e o risco com a aprendizagem contínua, por meio do qual, poder-se-ia criar e descobrir um futuro não-conhecido. Coexistem igualmente as visões compartilhadas e a ênfase nas fortalezas, com agendas estratégicas mutantes que refletem, antecipam e geram o futuro e se baseiam em um processo exploratório e experimental fundamentado na intuição e no raciocínio analógico (WHEATLEY, 1992). 
O papel do líder configura-se em construir paradigmas apropriados para compreender a instabilidade da dinâmica organizacional; para propiciar um clima que estimule a diversidade e promova a sinergia, no qual, o desacordo não seja sinônimo de deslealdade, que se revisem e questionem permanentemente os paradigmas, com a certeza de que são os modelos mentais das pessoas que determinam a capacidade da organização para enfrentar-se ao futuro.

O líder formal assemelha-se mais ao do treinador, cuja missão fundamental é instruir facilitar a sinergia e cuidar de que a mística, a disciplina e a confiança possibilitem os resultados esperados da equipe ao seu cargo. Este tipo de liderança é diferente à liderança burocrática exercida por muitos dirigentes. Essa é baseada na autoridade do cargo e em menor intensidade na liderança obtida com base no trabalho, comunicação e confiança.

Nesta nova modalidade de liderança, a chave está no "empoderamento" de todas as pessoas e não no líder estilo "Super-homem”, que mostra como o grande conhecedor, com capacidade de pensamento, decisão, que atua como "salvador" de um grupo anônimo e dependente. Entretanto, nesta época turbulenta, se ficarmos cuidando da ordem, seriamos arrasados sem ter a possibilidade de resposta ou de defesa. Devemos aprender a fluir acompanhando o tempo, situação fundamental neste tempo em que aquele que não inova e muda de mentalidade, não sobrevive.

\footnotetext{
Só sobreviveremos às crescentes investidas da competência internacional se nossa organização for criativa; se formos capazes de gerar novas opções estratégicas com maior rapidez que os competidores. Urge mudar o paradigma do equilíbrio estável: acreditar que, o êxito em longo prazo, procede da estabilidade, da harmonia, da regularidade, da disciplina e do consenso (WHEATLEY, 1992, p. 55).
}

Aproximação encima descrita implica certo grau de convergência conceitual entre os profissionais que integram as organizações de saúde e, por conseguinte, uma subcultura com linguagem, símbolos e significados próprios que dão identidade e unidade à organização. Em outras palavras, se estabelece um sistema de comunicação "sui generis" ao interior da 
organização, incluído nos diferentes grupos e especialidades de trabalho como são os dos hospitais, as organizações de serviços de saúde.

Luhmann e De Giorgio (1998) consideram que a comunicação se baseia em um conjunto de suposições voluntariamente assumidas por quem deseja estabelecer uma comunicação. Estas suposições, não só afetam a imagem que o emissor tem do possível receptor de suas mensagens, também afetam sua própria conduta e ações subseqüentes. Isto tem uma importância relevante para o bom andamento da organização e, por conseguinte, outorga mérito às pessoas que a integram, iniciando com aquelas que têm algum cargo de direção, pele efeito multiplicador de suas atitudes e estilos.

Os profissionais de enfermagem formam um grupo básico nas organizações de saúde, por estar localizado na primeira linha do atendimento de pessoas que, por alguma razão, requerem atenção saúde. Compreende-se, então, que o profissional de enfermagem, com cargos dirigentes, assume uma grande responsabilidade quanto ao exercício da liderança nas organizações de saúde.

Mediante essa constatada importância, esse estudo aborda o tipo de liderança exercido pelo profissional de enfermagem que ocupam cargos dirigentes nas organizações de saúde do sistema de saúde da Cidade do México, Distrito Federal.

O desenvolvimento da Enfermagem, no México, está vinculado com os processos histórico-sociais do país e com seus avanços econômicos, políticos, científicos e tecnológicos, especialmente, nos campos da saúde e da educação, em todos seus níveis. Isto tem se refletido na nova classe profissional do México, de maneira especial na profissão de enfermagem.

Atualmente o México, requer profissionais de enfermagem, novos atributos profissionais de liderança, com conhecimentos para o desempenho como agentes de mudanças e transformações contínua, dos processos de prestação de serviços de saúde, já que eles têm 
responsabilidades como dirigentes ou líderes nas organizações, como, hospitais, centros de saúde, escolas de enfermagem e equipes multidisciplinares.

O estudo da liderança em Enfermagem, no México, se considera pertinente, pois é um fenômeno pouco explorado e, devido à importância do tema, merece ser pesquisado em profundidade, visando a contribuir com a organização da prática. O interesse do estudo da liderança é observado na realização de alguns estudos (PÉREZ LOREDO, 1986):

\begin{abstract}
A Secretaria de Salubridade e Assistência, em 1954, criou a direção de enfermagem e trabalho social nomeando um médico como diretor. Quatro anos, mais tarde, pela exigência das enfermeiras, conscientes de que a participação em cargos administrativos favoreceria o desenvolvimento da enfermagem, em 1959, se criou a Direção Geral de Enfermagem. Nesta ocasião, foi nomeada uma enfermeira para regulamentar as profissões em todos os campos, simultaneamente, se nomearam dirigentes estaduais com autoridade e toma de decisões. Neste período, se fortaleceu a enfermagem com uma liderança nacional e em cada estado da República se elaborou programas de enfermagem para o atendimento preventivo e curativo da população, com ênfase nas áreas rurais (p.54).
\end{abstract}

Em 1964, a direção de enfermagem, organizou uma série de investigações clínicas, elaborou e redigiu normas de enfermagem, com regulamentos visando para guiar as ações da enfermagem no âmbito hospitalar e na comunidade e assim, suas ações começaram a ganhar maior força. Fatos como esses, em pesaram a causar desconforto na área médica, com o aparecimento de sentimentos de medo de substituição, como conseqüência do crescimento e segurança das ações de enfermagem frente a situações como epidemias ou em qualquer outra circunstância, sobretudo comunitária. O que geram a pressão exercida pela área médica, a direção de enfermagem foi eliminada, permanecendo por 25 anos, e deixando alguns cargos menores com funções de assessoria do grupo staff(BECERRIL, 2005).

Em 1979, a Enfermagem começam a perceber que a realização plena da profissão estaria de encontro com o controle das ações da profissão e, este não aconteceria enquanto o paradigma do atendimento à saúde estivesse centralizado no médico. A falta de liderança com apoio, de um organismo que normalize a direção de enfermagem que deve seguir a prática e a educação, assim como, a política e interesse das instituições de saúde, dificulta a definição de funções da 
enfermagem em seus diferentes níveis de preparação e em relação com as competências do pessoal médico.

A enfermagem tem lutado de formas distintas, assim, fortalecendo-se no processo, algumas organizações como o Colégio Nacional de Enfermeiras (CNE) e a Federação Mexicana de Associações de Faculdades e Escolas de Enfermagem (FEMAFEE), apresentam ainda atribuições limitadas.

Como conseqüência, dentro das instituições de saúde, e do trabalho de grupos de enfermeiros, se criou organizações com objetivos de coordenação. No ano 2000, com a mudança de partido político, na presidência da república mexicana, o novo governo escutou aos enfermeiros, os quais aproveitaram à conjuntura e foram parcialmente compreendidos iniciando-se uma nova etapa para a enfermagem mexicana. Foi criada a Comissão Interinstitucional de Enfermagem (COIE), que segudo Becerril (2005) refere ao grupo de apoio técnico integrado por profissionais da enfermagem. Esta comissão está encarregada pela proposta de diretrizes e alinhamentos gerais que possam ser recomendadas às autoridades de educação e saúde para a melhora da qualidade do atendimento de enfermagem e a qualidade educativa, assim como, estabelecem as normas de regulação da profissão. Integram esta comissão os representantes institucionais dos setores educativos e de serviço, assim como, de associações e colégios de profissionais da enfermagem.

A análise do exercício da liderança dos profissionais de enfermagem é um tema que por sua complexidade e extensão requer o aporte de várias disciplinas e especialidades, que estão fora do alcance da dessa pesquisa. Portanto, a elaboração do presente estudo limita-se aos estilos de liderança, da maturidade dos seguidores e das características da conduta percebidas pelos enfermeiros dirigentes de organizações como os hospitais gerais da Cidade de México do Distrito Federal (D. F.). 
No item um, para o estudo do fenômeno de liderança, o referencial teórico a ser seguido indica três elementos básicos: a) O ambiente; b) Os seguidores e; c) O líder.

a) $O$ Ambiente. Lugar onde se desenvolve a liderança de enfermagem. A organização jurídico-política denominada o "Sistema Nacional de Saúde do México" (SNS) que é expresso no item 1.1. Neste ponto, é descrita a fundação do sistema até o momento atual; assim como, políticas, objetivos, missão, descrição do sistema nacional de saúde do México, políticas de saúde, cobertura de atendimento para os mexicanos e o papel da enfermagem no SNS. Dentro deste quadro se analisa também a criação do sistema de saúde do governo da Cidade do México, D. F. (SSDF). No item 1.2. é apresentada à descrição de algumas características das organizações hospitalares onde se desenvolverá o estudo e, cujas características administrativas hospitalares são orientadas à luz da teoria burocrática e aos estudos que relacionam a orientação administrativa dos hospitais, e o papel da enfermagem no hospital.

b) Os seguidores. Foi considerado importante estudar quem são os seguidores, razão pela qual, no item 1.3 apresentam-se um panorama geral sobre a profissão, formação e prática de enfermagem no México.

c) O líder. No item 1.4. é apresentada uma análise de alguns enfoques e modelos de estilos de liderança visto como a base para estudo de (HERSEY; BLANCHARD, 1988). Este modelo por considerado como guia para o estudo, no que diz respeito ao tipo de liderança que percebem e dos quais praticam os dirigentes de enfermagem nos Hospitais Gerais da Cidade de México, D. F. Considera-se líder a pessoa que apresentam características particulares. Para tanto, foi seguida a característica de conduta Tipo A, estudada por Friedman e Rosenman (1976).

No item dois se apresentam as questões, os objetivos e as hipóteses do estudo e no item três a trajetória metodológica da investigação, assim como, as considerações bioéticas, local de estudo, instrumentos, procedimento da coleta de dados e processamento dos mesmos para a 
interpretação dos resultados. Os resultados do estudo são apresentados no item quatro e no item cinco as considerações finais.

Os resultados evidenciaram o cumprimento do modelo de Hersey e Blanchard e oferecem importantes pontos de vista para o fortalecimento da liderança em enfermagem nos hospitais gerais da cidade do México, D. F. 


\section{CONSTRUÇÃO DO APORTE TEÓRICO}


Para aprofundar o estudo do fenômeno de liderança descreve-se no primeiro capítulo o aporte teórico que delimita o estudo considerando três elementos básicos de liderança: o ambiente, incluindo o Sistema Nacional de Saúde e o Hospital como organização de trabalho de enfermagem, os seguidores, incluindo os profissionais de enfermagem e suas atitudes e o líder, que descreve elementos de liderança de maneira geral e particular de enfermagem, tomando como referência o modelo de Hersey e Blanchard.

\subsection{SISTEMA NACIONAL DE SAÚDE DO MÉXICO (SNS)}

O Sistema Nacional de Saúde é representado pela Secretaria de Saúde (SS) e, tem como missão, contribuir com o desenvolvimento humano justo, universal e sustentável, por meio da promoção de saúde com serviços integrais de alta qualidade, que satisfaçam as necessidades e respondam às expectativas de uma população de 107 milhões de habitantes. O SNS oferece, aos prestadores do serviço, na utilização correta, transparente e eficiente dos recursos, e promovendo uma ampla participação dos cidadãos. Para o cumprimento desta missão, o governo mexicano, tem como guia o Plano Nacional de Saúde 2001-2006, no qual, descreve o sistema de saúde como universal, eqüitativo, solidário, plural, eficiente, de alta qualidade, antecipatório, descentralizado, participativo e vinculado ao desenvolvimento.

O Plano Nacional de Saúde da Secretaria de Saúde (MÉXICO, 2001a, p. 32) propõe:

“[...].no ano 2025 todo mexicano deverá ter acesso a um seguro de saúde, independentemente de sua capacidade de pagamento, seu grau de risco ou sua afiliação trabalhista. Os serviços que serão oferecidos (públicos ou privados) serão de alta qualidade técnica e deverão satisfazer às expectativas dos usuários. Os serviços serão proporcionados por prestadores de serviço profissionais com preparação credenciada, que usarão intervenções baseadas em evidências científicas. Estes serviços, ademais serão proporcionados em ambientes dignos e em uma cultura institucional que promova o desenvolvimento e atualização profissional dos prestadores de serviço, para a satisfação dos usuários e para o respeito aos direitos humanos, incluindo o direito à informação[...]".

O SNS está organizado para se antecipar às necessidades de saúde da população, para o qual está inter-relacionado com outros sistemas, tais como: o sistema de desenvolvimento social, educação, meio-ambiente, segurança social entre outros, já que de maneira isolada não poderia cumprir sua missão. O SNS implanta de maneira crescente políticas integrais 
direcionadas à melhoria do bem-estar da população de acordo com modelos vigentes atualmente nos paises desenvolvidos. Desta maneira, se espera que as famílias mexicanas possam se sentir apoiadas por um sistema de saúde baseado na excelência de seus profissionais e na cobertura universal da população. Este planejamento de SNS é acertado só que a realidade é insuficiente porque não cobre as necessidades da população e só esta escrita a iniciativa, para a operacionalização esta distante.

\subsubsection{Origem do Sistema Nacional de Saúde}

No México, o SNS foi criado em 1917, com a promulgação da Constituição Política dos Estados Unidos Mexicanos, na qual, no artigo $4^{\mathrm{o}}$, se contempla o direito dos mexicanos à proteção de sua saúde. O SNS vem sendo construído e alguns dados são mencionados para compreender sua gênese.

Com a aparição de epidemias e pandemias, em 1937, foi estabelecida a obrigação de prestar serviços médicos mediante hospitais. Em 1943, iniciaram-se as primeiras reformas do setor de saúde com a fusão da Secretaria de Assistência Pública e do Departamento de Salubridade. Esta integração gerou uma nova organização chamada Secretaria de Saúde e Assistência (SSA).

Simultaneamente foram organizados os serviços de atendimento médico, salubridade e de assistência social para atender a problemas epidemiológicos e infecciosos. A prestação de serviços foi feita mediante serviços profissionais organizados por de sistemas públicos de atendimento médico para a população, com serviços preventivos, de cura e de reabilitação, os quais seriam oferecidos no domicílio, vias públicas, consultórios, clínicas e hospitais, assim a cobertura seria estendida a toda população (SOBERÓN, 1983a).

$\mathrm{Na}$ década de os quarenta sobressaiu o primeiro plano para a construção de unidades médicas no país. Assim, foram criados 39 hospitais e 366 centros de saúde. Ao mesmo tempo, foram construídos hospitais descentralizados como os institutos sob a direção de autônoma 
para o atendimento de especialidades básicas para a população, o Instituto de Enfermidades da Nutrição, o Instituto de Cardiologia e o Hospital Infantil do México (SOBERÓN, 1983a).

Com o desenvolvimento industrial surgiu a necessidade de proteger a classe operária, e, em 1943, sob o amparo da Lei do Seguro Social, foi criado o Instituto Mexicano de Seguro Social (IMSS): “Organização descentralizada com personalidade jurídica, sustentada economicamente pelo Estado, pelos patrões e pelos trabalhadores, constituído como um serviço nacional obrigatório". No que se refere à saúde, as prestações outorgada pelo IMSS compreende: os riscos de trabalho, as doenças, a maternidade e a invalidez. Assim, a organização tem o compromisso de outorgar atendimento médico integral a todos os assegurados (SOBERÓN, 1983a).

Com os movimentos sindicais, dos trabalhadores do magistério e dos trabalhadores a serviço do Estado conquistaram em 1959 a criação do Instituto de Seguro e Serviço Social para os Trabalhadores do Estado (ISSSTE). Trata-se de uma organização é pública descentralizada que, para o seu funcionamento, conta com o aporte dos trabalhadores e do Governo Federal. Dessa forma, por meio de uma única instituição, prestam os serviços médicos correspondentes aos seguros de doenças não-profissionais, acidentes de trabalho e doenças profissionais, aposentadorias, invalidez, velhice e morte. Ainda oferece serviços de reabilitação e de reeducação em condições invalidez, empréstimos de curto prazo e empréstimos hipotecários (SOBERÓN, 1983a).

Cordera e Bobenrieth (1992) descrevem, na década de 80, o desenvolvimento de outra reforma importante no México. Baseada nos acordos da Organização Mundial da Saúde (OMS) foi proposta a estratégia "saúde para todos no ano de 2000", assim, consolidando a necessidade da criação de um Sistema Nacional de Saúde com o fim de organizar o atendimento primário de saúde nas comunidades, o sistema de referência e de contrareferência, a organização do atendimento dos serviços de saúde nos três níveis de 
complexidade, com políticas claras e diferentes para o atendimento médico-curativo intrahospitalar, individualizado e com programas de atendimento à saúde para diminuir o grau de doenças e ampliar a cobertura dos serviços.

O SNS do México ficou oficialmente conformado como um sistema moderno no início da administração do Presidente Miguel de la Madrid Hurtado (1984-1988)

SOBERON (1983b, p. 20) descreve a concepção do SNS como:

\begin{abstract}
“[...] um sistema de coordenação de ações em busca da coerência, da harmonia e da flexibilidade necessárias para estabelecer e oferecer acesso aos serviços de saúde. Uma forma de dar um uso mais eficiente dos recursos e contribuir à conquista de uma sociedade mais igualitária, segundo dois grandes objetivos: ampliando a cobertura dos serviços de saúde a toda população, dando prioridade aos núcleos rurais e urbanos mais desprotegidos e, elevando a qualidade dos serviços que são prestados, tendo como objetivo o alcance do mínimo satisfatório, o qual, servirá como base para desenvolvimentos posteriores [...]”
\end{abstract}

A emenda do artigo $4^{\circ}$, da Constituição Política dos Estados Unidos Mexicanos, sobre a exposição de motivos do direito dos cidadãos à proteção da saúde, reflete o propósito do Governo Federal de proteger esse direito mediante o SNS (MÉXICO, 2001a). As características como planejamento é acertado, mas na realidade é muito complexo em todo o país.

\title{
1.1.2 Políticas de saúde
}

A Lei Geral de Saúde e, seu artigo $6^{\circ}$, estabelece que o SNS deve proporcionar serviços de saúde a toda a população, assim como, melhorar a qualidade dos mesmos, têm prestar atenção aos problemas sanitários prioritários, aos fatores que condicionem e causem danos à saúde, prestar especial atenção nas ações preventivas e contribuir com o desenvolvimento demográfico harmônico do país, assim como colaborar com o bem-estar social da população mediante serviços de assistência social, principalmente a menores em estado de abandono, e a anciãos desamparados e a incapacitados. Fomentar o bem-estar e propiciar a sua incorporação a uma vida equilibrada econômica e social, estimulando o desenvolvimento da família e da comunidade, assim como, a integração social e o crescimento físico e mental da criança. Apoiar na melhoria das condições sanitárias do meio-ambiente para propiciar o 
desenvolvimento satisfatório da vida; impulsionar um sistema racional de administração e desenvolvimento dos recursos humanos para melhorar a saúde. Além disso deve estar aliado às modificações dos padrões culturais que determinem hábitos, costumes e atitudes relacionadas com a saúde e utilização dos serviços relacionados com sua proteção. Só que em operação é complexo se precisam muitos recursos e disposição de todos os mexicanos (MEXICO, 1987).

O SNS se integra com três instâncias que instrumentam o programa nacional de saúde: instituições do setor saúde, para as quais aplica a obrigatoriedade, organizações federais as quais estai vinculadas por meio da coordenação pelo o governo federal e as do setor social e privado, incorporando-se mediante a concentração e indução do apoio à consulta popular.

O Plano Nacional de Saúde é o instrumento que forma parte do Plano Nacional do Governo Federal (Poder Executivo Federal), encarregado das políticas e estratégias para consolidar o SNS (MÉXICO, 2000b. p. 112):

“[...] setorialização, a descentralização de serviços de saúde, modernização da SS, a coordenação inter-setorial, a Participação comunitária; desenvolvimento de recursos humanos para a saúde; homologação salarial e funcional para o equilíbrio de salários e responsabilidades de trabalhadores; impulso à investigação de saúde; o financiamento dos serviços; a racionalidade no manejo de insumos; a melhoria da informação de saúde; formação de Recursos Humanos para os serviços integrais de saúde para toda a população; o reforço de programas preventivos e a realização de ações focalizadas na melhorar dos indicadores de saúde (Morbimortalidade). Permitindo tornar o sistema com Disponibilidade, Acessibilidade e Qualidade [...]"

O Sistema Nacional de Saúde está fundamentado na eqüidade, cobertura, qualidade e eficiência dos serviços de saúde. Para o alcance de seus objetivos busca cumprir com quatro funções básicas: prestação de serviços, financiamento, direção do sistema e a geração de recursos para a saúde.

O marco de referência das políticas de saúde, no documento, parece lógico, mas na sociedade, estas intenções se diluem e não são apreciadas de maneira adequada. A cobertura é limitada e os problemas sanitários cada vez são maiores. Com a mudança do perfil 
demográfico a população da terceira idade se encontra com atendimento limitado, como descrito a seguir.

\subsubsection{Cobertura do atendimento para os mexicanos}

A cobertura do atendimento para a população mexicana está contemplada nos seguintes pontos (MÉXICO, 1999b):

a) Organização do Seguro Social Mexicano, a qual ampara $40 \%$ da população mexicana e é representada por instituições como: o IMSS, o ISSSTE, o PEMEX, o SEDENA, o SEMARNA, o Sistema de Transporte Coletivo, Comissão Nacional Bancária de Seguros, Loteria Nacional Financeira e a União Nacional de Promotores de Açúcar. O sistema de seguro social busca garantir o direito à saúde, à assistência médica, à proteção dos meios de subsistência e aos serviços sociais que contribuem com o bem-estar individual e coletivo.

b) Setor Privado, representado por organizações que oferecem recurso para o cuidado da saúde à população que atende, e que participa pouco das tarefas habituais da medicina oficial, do seguro social ou da assistência pública. Está representada pela população que, economicamente, é capaz de pagar pelos serviços de saúde. População essa, que representa aproximadamente $2 \%$ da população.

c) A “população aberta”, que diz respeito à população sem seguro social. Representa $58 \%$ da população. A população é atendida pelos Institutos Nacionais de Saúde e Seguro Popular de Saúde. Com o objetivo de fortalecer o acesso desta população ao seguro de saúde, o Plano Nacional de Saúde criou o Seguro Popular de Saúde (SPS), o qual é de caráter universal, um sistema eqüitativo e que garante a qualidade nos serviços. Consiste em um prépagamento subsidiado com fundos públicos. Está dirigido, principalmente, à população de baixos recursos econômicos. Mediante único pagamento anual, o assegurado e a sua família têm acesso ao atendimento por consulta ou nos diferentes serviços. Desta maneira, podem aceder ao chamado Seguro de Saúde da Família do IMSS, Frenk (2001). 
Sem importar a condição de trabalho, localização geográfica ou capacidade de pagamento, o SPS foi oferecido gradualmente às famílias mexicanas carentes de acesso aos serviços e saúde. Nos primeiros dois anos, os esforços foram centralizados no atendimento às famílias urbanas e de baixa renda. Este projeto contempla um período gradual de sete anos (iniciado em 2004). Julio Frenk, da Secretaria de Saúde, garante que, de 50 milhões de pessoas que precisam de seguro social, 22 milhões já contam com seguro, e que, contando com a eficiência do sistema, para o ano de 2010, o México disponibilizará a cobertura do seguro social para todos os mexicanos (FRENK, 2003).

O SNS por meio de um planejamento permite enfrentar o desafio estabelecido no Programa Nacional de Saúde 2001-2006 de oferecer proteção à saúde a todos os mexicanos. Portanto, oferece uma opção de seguro público em matéria de saúde para as famílias e cidadãos que, por sua condição trabalhista ou sócio-econômica, não são assegurados dentro das instituições de seguro social.

O Seguro Popular de Saúde (SPS) tem cinco objetivos específicos: 1. Reduzir o gasto privado das famílias afiliadas; 2. Outorgar um pacote explícito de intervenções e seus medicamentos, que correspondem ao perfil epidemiológico e à demanda dos serviços e as necessidades de saúde; 3. Fomentar a atenção oportuna da saúde das famílias mexicanas, evitando a postergação e conseqüente agravamento de doenças por motivos econômicos; 4. Fortalecer o sistema público de saúde para reduzir a lacuna entre famílias que contam com o seguro social de saúde e as que não contam; 5. Contribuir com a superação das iniqüidades e atrasos na distribuição dos recursos, entre entidades federativas com diferentes níveis de desenvolvimento em matéria de saúde (MEXICO, 2003a).

O SPS foi criado em 2004, suas atividades estão programadas até o ano 2010, ano em que o 58\% da "população aberta" (que não conta com seguro social) deverá usufruir do seguro de atenção pública de saúde. Para cobrir todo o território mexicano, será considerada a infra- 
estrutura hospitalar necessária para o atendimento da demanda de serviços, sendo basicamente destinada "à existência de grupos organizados com capacidade de contribuir, parcial e voluntariamente, segundo o custo subsidiado da quota do seguro popular" (MEXICO, 2001a).

Os beneficiários que precisam de algum serviço médico, não contemplado na unidade médica de associação, poderá ser encaminhado para outra unidade onde possa receber o atendimento requerido, mas os gastos gerados pelo transporte, alimentação e hospedagem do paciente e/ou de seu(s) acompanhante(s) será responsabilidade do usuário (MÉXICO, 2003a).

$\mathrm{Na}$ execução do programa, a Secretaria de Saúde é definida como a instância normativa do Programa, a instância que garante a coerência e coordenação entre o Seguro Popular de Saúde e os demais programas, assim como, com as demais instituições do setor de saúde como os Institutos. (MEXICO, 2003a).

Os Institutos Nacionais de Saúde (INSalud), como referidos anteriormente, fazem o atendimento para a população "aberta" (que não conta com seguro médico social e são de alta especialização). Esse, forma parte da Secretaria de Saúde, por sua vez, é um grupo incorporado por dez institutos dentro do SNS. Seu campo de ação é o território nacional e tem como objetivo a investigação científica, a formação e capacitação de recursos humanos altamente qualificados, assim como, a prestação de serviços de atendimento médico de especialidade. São organizações públicas descentralizadas. De acordo com a Lei Orgânica da Administração Pública Federal, foram criados por lei ou por decreto e possuem personalidade jurídica e patrimônio próprio. É regulamentado pela Lei dos Institutos Nacionais de Saúde Publicada e coordenado pela Secretaria de Saúde, através da Coordenação Geral dos Institutos Nacionais de Saúde (MEXICO, 2000b, p. 38).

“[...] Nos INSalud se oferece atendimento médico do mais alto nível em seu campo, formam-se especialistas e professores em quase todas as áreas médicas e se realizam atividades de investigação biomédica, clínica e sócio-médica. Na América Latina, a medicina mexicana mantém um alto prestigio. A existência dos resultados alcançados pelos INSalud, é sem dúvidas um dos pilares que sustentam esse prestigio; nas áreas de Cardiologia, Nutrição, Doenças Respiratórias, Puericultura, Pediatria, Reabilitação, Neurologia e Neurocirurgia, Psiquiatria, Saúde Pública e Cancerologia. Um elevado número de especialistas latino- 
americanos recebem treinamento nos INSalud correspondentes. A investigação científica tem aportado notáveis contribuições em diversos campos, sendo os mais frutíferos nos tempos recentes as neurociências, a imunológica, a gastroenterologia e a saúde pública [...]”.

\subsubsection{Reflexão do SNS}

A partir da década de oitenta o seguro social foi ganhando importância através dos diversos movimentos sociais iniciados principalmente pela classe trabalhadora; nos últimos anos teve um grande giro com relação à busca dos direitos dos trabalhadores; isto deriva principalmente das políticas públicas que são executadas atualmente, políticas, que se propõem seguir alinhamentos internacionais que privilegiam um modelo econômico e político em nível mundial regulamentado por organizações internacionais como o Banco Mundial e o Fundo Monetário Internacional.

Como conseqüência deste panorama mundial, no México, se iniciou uma reestruturação econômica dando lugar a um novo modelo econômico: o Neoliberal, que tem como referencia imediata a abertura de mercados mediante a globalização e a internacionalização da economia (LAURELL et al., 2005).

Na década de oitenta, no país, no que tange às políticas, esta se apresentou bastante crítica, de maneira especial com as mudanças suscitadas em matéria econômica. Uma das principais preocupações do país, era a dívida externa e a crescente inflação. Ao final de 1983 se iniciou uma política relativa a uma mudança na participação estadual. A mudança se centrou em fatores importantes como a descentralização do poder do estado, ou seja, de um Estado proprietário de empresas a um Estado promotor de bem-estar social.

Entre 1985 e 1988, a economia mexicana iniciou um processo de abertura comercial que se expressou claramente com o ingresso do México no GATT (Acordo Geral de Tarifas e Taxas, agora Organização Mundial de Comércio) e com início das negociações para a assinatura do Tratado de Livre Comércio, com os Estados Unidos e Canadá (GIL, 1997). 
Política, essa que começou a ganhar força a partir de 1988, na administração de Carlos Salinas de Gortari, Presidente da República Mexicana entre os anos 1988 e 1994.

Nesse período, os apoios aos serviços de saúde se restringiram gradualmente. Por exemplo, os orçamentos captados do IMSS e do ISSSTE correspondiam a $44 \%$ menos que os correspondentes a 1983; e na Secretaria de Saúde foi de 50\% menos que no ano 1985. A conseqüência imediata desta redução se observou na desvalorização das instituições de saúde, com baixos salários dos trabalhadores, restrições às compra de equipamento, maior cobertura da população atendida sem aumento de recursos e em um importante questionamento sobre o prestigio médico e social das instituições.

A tendência política e econômica era diminuir a intervenção do Estado em certos aspetos. Com esse objetivo, foi criado em 1984 o Sistema Nacional de Saúde, o qual contava com atribuições para planejar, coordenar e integrar as atividades e programas das instituições públicas relacionadas com a saúde da população (LANDGRAVE; TETELBOIN, 2006). Por meio desta organização se pretendeu realizar as reformas que contribuíam para relegar ou diminuir a intervenção do Estado, as quais, sem dúvidas, repercutem tanto no nível de atendimento, quanto nos diversos processos de relação dentro da instituição, como as relações médico-paciente, o vínculo do paciente com a instituição, ou a noção de saúde-doença, entre outros.

Em termos gerais, as reformas propostas reestruturam as participações do Estado e dos trabalhadores. Como aponta Laurell (2004), as reformas do Setor de Saúde se baseiam em uma estratégia neoliberal e dirige as necessidades, em saúde, a serem cobertas pelos indivíduos, pela família ou pelo mercado, razão pela qual, ao Estado só corresponde impulsionar ditos serviços, e não financiá-los.

O Estado compartilha, junto com o setor industrial e trabalhista, o aporte econômico do seguro social. Atualmente, se pretende criar condições favoráveis para instaurar uma 
política de mercado e assim capitalizar o organismo do seguro social. Por conseguinte, se pretende organizar o Setor Saúde segundo as necessidades geográfico-econômicas. E assim maneira, o novo modelo organizativo estará integrado por três subsistemas: o seguro privado, o seguro social e o dos sistemas estaduais de saúde dirigidos à população rural ou suburbana (que não contam com seguro médico social) (LAURELL, 2004). Ações como essas, permitem a distribuição de insumos para o setor saúde, mas também, a segmentação da população que um acesso aos serviços. É de interesse, priorizar ao Seguro de Doenças e Maternidade, consolidar o Seguro Social para a Família e melhorar a qualidade dos Serviços médicos.

Seguindo a lógica iniciada no governo de Miguel de la Madrid (1984-1988), continuada nos governos de Salinas de Gortari (1989-1994) e de Zedillo (1995-2000), se conformou o Programa Nacional de Saúde que tornou possível concretizar as posturas econômicas e políticas referentes à saúde, que há mais de 18 anos, vêm sendo aplicadas no México, convertendo o âmbito da saúde em um mercado, no qual os meios de produção do bem e das formas de consumo dão sustento às necessidades básicas da população. No relatório publicado em 1999, sobre a Saúde no Mundo, a Organização Mundial da Saúde promove um novo universalismo e reconhece os limites do Estado. O novo universalismo reconhece que se os serviços devem ser prestados a todos, conseqüentemente, nem todos os serviços poderão ser prestados. De acordo com uma determinada priorização, os serviços de maior custo-efetivo devem ser providos primeiro (LEAL, 2004).

A saúde, de um bem acessível que deveria estar ao alcance de todos, passa a ser um bem de mercado, isto é, um bem de consumo, já que sob estes alinhamentos e o estabelecimento de quotas, se estaria trabalhando sob o mesmo princípio que as seguradoras privadas, nas quais, os custos a cobrir correspondem a certos níveis de atendimento. É deixado de lado, o princípio de solidariedade e eqüidade social, propostos na conformação inicial do seguro social. 
Atualmente, o setor saúde exige reformas no aspecto econômico, político e social. Os aspectos econômicos, há muito tempo, têm contribuído na origem de uma crise no interior da instituição, repercutindo no atendimento médico e na execução, privilegiando-se, de maneira parcial, número de pacientes atendidos, número de leitos disponíveis, entre outros. O PNS estabelece que as "contribuições devem ser proporcionais à capacidade de pagamento" e propõe, abertamente, subsídios escalonados para o atendimento integral e resolutivo da doença (segundo a renda econômica familiar), por meio do seguro popular, da "ampliação" do seguro social e da "regulação" dos seguros privados via Instituições de Seguros Especializadas em Saúde (ISES) (LAURELL, 2004).

Para atender a uma maior porcentagem da população, no México, o governo do presidente Fox (2000-2006) desenvolveu o programa de saúde denominado "Seguro Popular de Saúde - SPS”, dirigido à população que não dispõe de um seguro médico. Assim, o Seguro Popular de Saúde seria voluntário e gratuito para as pessoas de escassos recursos. É também, disponibilizado para indivíduos com salário superior a três salários mínimos (aproximadamente 14 dólares diários), nesse caso, é recolhida uma quota anual de 66 dólares para garantir o seguro de toda a família. Outro ponto que chama a atenção é que o seguro não cobre as doenças mais freqüentes, entre mexicanos, como as doenças crônico-degenerativas e as lesões graves.

O Seguro Popular de Saúde não conta com hospitais próprios, desta maneira o assegurado deve buscar a clínicas de saúde estaduais ou federais. Segundo as autoridades, o governo federal contribui com aproximadamente $70 \%$ dos recursos, os governos estatais com $20 \%$ e as famílias com o restante. O custo para o atendimento de complicações é responsabilidade da população. Ao parecer estas estratégias estariam dirigidas à privatização dos serviços de saúde (LAURELL et al., 2005). 


\subsubsection{A Secretaria de Saúde do Governo do Distrito Federal (SSDF)}

O Distrito Federal é a entidade federativa com a maior concentração de serviços de saúde do país, mas este sistema está altamente fragmentado por serviços diferenciados segundo a capacidade de pagamento ou pré-pagamento da população. Por intermédio da entidade do Distrito Federal, se atende o total da população residente, tanto a beneficiada pelo seguro social, como aquela que não conta com benefícios do seguro social ou, no México, conhecida como "população aberta" e a uma parte da população da periferia, assim descrito por Laurell et al., (2005. p. 34):

“[...] O sistema de saúde do DF está constituído por três sub-setores que contam com distintas opções de financiamento, afiliação e prestação de serviços, o que o torna um sistema desarticulado e segmentado de acordo com a inserção trabalhista (participação ou não na economia formal) da população que atende, como de seu nível de ingresso (ou capacidade de pagamento): a) setor público para a população não assegurada ou aberta; b) setor do seguro social para pessoas afiliadas ao seguro social e c) setor privado [...]".

O sistema público inclui como entidades diferenciadas os Institutos Nacionais de Saúde (INSSS), os grandes Hospitais Federais e os Serviços de Saúde Mental (consideradas organizações descentralizadas, autônomas e setorializadas), a Secretaria de Saúde Federal, a Secretaria de Saúde do Governo do Distrito Federal e a Organização Pública Descentralizada (OPD) de Serviços Públicos de Saúde do Distrito Federal.

O subsistema de seguro social protege a saúde dos trabalhadores inseridos na economia formal com contratos de trabalho e a seus familiares. Em 2000, a população de familiares representava uma cifra superior a 4,6 milhões de pessoas no Distrito Federal. O sistema está constituído pelo Instituto Mexicano de Seguro social (IMSS) que concentra o maior número de assegurados (71,3\%), seguido pelo Instituto de Seguro e Serviço Social para os Trabalhadores do Estado - ISSSTE (25,4\%), Petróleos Mexicanos - PEMEX, as Forças Armadas - SEDENA e a Marinha - ISSFAM (2,6\%) e diversos seguros para trabalhadores estaduais e particulares (0,7\%) (LAURELL, et al., 2005). 
Com relação a recursos para o ano 2002, Laurell et al., (2005) refere que no Distrito Federal os subsistemas de seguro social e diferentes modalidades de seguro médico dispunham de 589 unidades de consulta externa, 50 hospitais gerais e 65 de especialidades, 16.856 leitos; 6.036 camas não-contabilizadas; 29.500 médicos e 30.637 enfermeiras. Recursos distribuídos entre os serviços de atenção para assegurados e não assegurados. O setor privado, que funciona em um contexto pouco regulado, inclui pequenos consultórios, clínicas e grandes empresas da saúde vinculadas à indústria das asseguradoras e conta com o monopólio da administração privada dos fundos de saúde nas Instituições de Seguros Especializados em Saúde (ISES), concentrados nos segmentos da população residente no Distrito Federal de maior poder aquisitivo. Em 2002, os recursos materiais e humanos da SSDF foram de 314 unidades médicas, 5.109 médicos, 5.866 enfermeiras, 1.832 consultórios, 5.779 leitos e 1.054 leitos não contabilizados (MÉXICO, SSDF, 2001c).

Os segmentos da população, prestadores de serviços de saúde e de benefícios para a população do Distrito Federal, requerem conexões com outros segmentos, mostrando relação com o seguro social. Ou seja, a relação dos usuários do seguro social e os que dispõem de um seguro privado, muitas vezes, outorgado como benefício trabalhista adicional. A coordenação entre instituições para o intercâmbio de serviços mostra-se tradicionalmente baixa e pouco regulada.

A segmentação e fragmentação do sistema de saúde do Distrito Federal têm provocado desigualdade entre os diferentes grupos de população no acesso aos serviços, assim como, na garantia de condições equivalentes de atenção. Situação que, em virtude do predomínio do gasto para o acesso ao atendimento da saúde, têm ocasionado a tendência, entre os de menos recursos econômicos e menos informados, de ficar fora do sistema. Não conseguindo a garantia do direito à saúde (MEXICO, SSDF, 2001c).

“[...] SSDF, é a encarregada da formulação e condução das políticas de saúde no Distrito Federal, e sua orientação responde à garantia da proteção do direito à saúde, através de programas de acesso gratuito ao atendimento médico integral e 
aos medicamentos. Centra seu interesse na população mais desfavorecida da cidade, desde a perspectiva de construção de cidadania e das responsabilidades públicas para garantir seus direitos. Esta orientação a leva adiante em um entorno nacional de reforma do sector saúde que oferece a competência e a promoção da medicina privada como solução aos problemas. E cuja essência consiste em introduzir o seguro universal, ainda que voluntário, para dar sustento econômico à lógica de competência mercantil na prestação de serviços de saúde, com o fortalecimento da mescla público-privado para que os administradores do financiamento e os prestadores dos serviços compitam pelos clientes da saúde[...]".

O convênio de descentralização, entre a Secretaria de Saúde Federal e o Governo do Distrito Federal, assinado em julho de 1997, propiciou que os serviços de saúde para a população sem seguro social ficassem divididos em duas entidades administrativas: no primeiro nível dentro da Organização Pública Descentralizada (OPD) "Serviços de Saúde Pública do Distrito Federal" e a dos hospitais na SSDF. Este convênio propiciou a fragmentação nos serviços, ao descentralizar a estrutura e os recursos dos serviços de saúde pública sem integrá-los ao dos hospitais, por esta razão, atualmente se conta com duas estruturas orgânicas e orçamentárias, diversos programas de ação, distintas culturas organizacionais, jurídicas e laborais. A SSDF conta com aproximadamente 23 mil trabalhadores afiliados a dois distintos sindicatos: o Sindicato Único de Trabalhadores de GDF local e o Sindicato Nacional de Trabalhadores da Secretaria de Saúde Nacional.

A população de responsabilidade da SSDF, no seu universo teórico de atendimento individualizado em saúde, é de aproximadamente 3,9 milhões de pessoas que habitam no Distrito Federal e que carecem de seguro social público, há aproximadamente $5 \%$ que se auto-exclui deste atendimento por recorrer ao setor privado.

Em relação aos recursos, a SSDF conta com 26 hospitais, dos quais oito são hospitais gerais (La Villa, Gregorio Salas, Rubén Leñero, Balbuena, Xoco, Iztapalapa, Milpa Alta e Ticoman). Em relação ao potencial humano, se conta com um registro de 5.109 médicos, 5.866 enfermeiras. Do total de enfermeiras, $37 \%$ se encontram no primeiro nível de atenção e $63 \%$ no segundo; dessas $53 \%$ são gerais e $10 \%$ especialistas. 
A organização possui o planejamento e coordenação da saúde da cidade do México, estabelecem procedimentos para conseguir que a população e as comunidades participem nas decisões relativas ao sistema de saúde e assumem a responsabilidade da auto-assistência, assim como, da assistência no seio da família e da atual atenção da comunidade.

A lei de saúde do Distrito Federal enfatiza (MEXICO, SSDF, 2001c, p. 332):

\begin{abstract}
“[...] deve proporcionar serviços de saúde à população e melhorar a qualidade dos mesmos atendendo aos problemas sanitários prioritários do Distrito Federal e aos fatores que condicionem e causem danos à saúde, com especial interesse nas ações preventivas. A atenção à saúde é proporcionada em três níveis com um sistema de referencia e contra referência. Os recursos profissionais de saúde são planificados e treinados baseado nas necessidades de cada nível e necessidades da população, como parte integrante da infra-estrutura sanitária. Considera-se a coordenação dentro do setor de saúde. Se prevêem ações inter-setoriais. Desenvolve-se a investigação sobre o sistema de saúde, entre outros [...]".
\end{abstract}

A Lei de Saúde, SSDF, também deve proporcionar serviços de saúde à população e melhorar a qualidade dos mesmos atendendo aos problemas sanitários prioritários da população e os fatores que condicionem e causem danos à saúde, com especial interesse nas ações preventivas. Os objetivos do SSDF são: 1. colaborar com o bem-estar social da população, mediante serviços de assistência social principalmente a menores de idade em estado de abandono, anciãos desamparados e incapacitados, para fomentar seu bem-estar e propiciar sua incorporação a uma vida equilibrada econômica e socialmente; 2. Dar impulso ao desenvolvimento da família, da comunidade, à integração social e ao crescimento físico e mental da infância; 3. Apoiar a melhoria das condições sanitárias do meio-ambiente que propiciam desenvolvimento satisfatório da vida; 4. Impulsionar um sistema racional de administração e desenvolvimento dos recursos humanos para melhorar a saúde.

Soma-se, a esses objetivos, o fomento do impulso ao desenvolvimento da família, da comunidade, à integração social e ao crescimento físico e mental da infância; apoiar a melhoria das condições sanitárias do meio-ambiente que propiciem o desenvolvimento satisfatório da vida; impulsionar um sistema racional de administração e desenvolvimento dos recursos humanos para melhorar a saúde; coadjuvar com a modificação dos padrões culturais 
que determinam hábitos, costumes e atitudes relacionados com a saúde e com o uso dos serviços para sua proteção; prestar, de forma eficiente, os serviços de salubridade geral e local a que se refere esta lei e realizar as ações de regulação e controle sanitário nos termos deste ordenamento e demais disposições aplicáveis; coadjuvar com a modificação dos padrões culturais que determinam hábitos, costumes e atitudes relacionados com a saúde e com o uso dos serviços que se preste para sua proteção; tornar real o direito de proteção a saúde e avançar na vigência de gratuidade, a universalidade e a integralidade na atenção da saúde, construindo o caminho para assegurar este direito, a partir do fortalecimento dos serviços públicos e de seu financiamento solidário (MÉXICO, 2001c).

\subsubsection{Enfermagem no Sistema Nacional de Saúde (SNS)}

A situação da estrutura funcional de enfermagem, no México, está a cargo da Comissão Interinstitucional de Enfermagem (COIE), a estrutura foi criada pela Secretaria de Saúde. A seguir descreve-se brevemente seu Plano Reitor de Enfermagem.

A estrutura está alicerçada nos desafios prioritários do Programa Nacional de Saúde 2001-2006 e incluem a eqüidade na prestação dos serviços, a qualidade em suas dimensões técnica interpessoal e a proteção financeira da população (MEXICO, 2001b, p. 41). 
definição de diretrizes que incidam na excelência dos serviços e no fortalecimento profissional $[\ldots] "$.

Para integrar o Plano diretor de Enfermagem foi realizado um diagnóstico estratégico identificando-se: deficiências na qualidade do atendimento de enfermagem determinadas pelo reduzido número de enfermeiras e condições deficientes da prática e inconsistências no sistema educativo de enfermagem. Uma vez concluída a análise e, como resposta à problemática, a COIE elaborou um plano integral de trabalho congruente com as políticas de saúde, especificamente com aquelas dirigidas a alcançar a qualidade nos serviços de saúde, coincidentes com as características institucionais e com a heterogeneidade da situação nacional da enfermagem.

Um aspecto iniludível, na determinação do plano, foi a formulação da visão da missão da enfermagem mexicana são das políticas de trabalho que incluem: a coordenação interinstitucional, inter-setorial inter-estadual; o trabalho inter-profissional através de alianças estratégicas; o trabalho integrado, vinculado aos propósitos educativos de assistenciais e o alinhamento de negociação, com o objetivo de alcançar consensos na determinação de diretrizes. Os objetivos visam contribuir com a melhoria da qualidade do atendimento dos serviços de enfermagem para elevar a qualidade de saúde da população assim contribuir com a melhora das condições da prática profissional para a regulação do sistema educativo em enfermagem. Para isto, as estratégias contam com uma avaliação sistematizada da qualidade do desempenho nos serviços de enfermagem, um modelo de organização de enfermagem para fazer mais efetiva a gestão dos serviços de enfermagem, modelos de atendimento de enfermagem que privilegiam as ações de caráter preventivo e promocional da saúde e instituições educativas acreditadas para responder às demandas de atenção (MEXICO, 2001b).

Para alcançar os resultados se definiram os fatores críticos de êxito: a qualidade no atendimento de enfermagem e a qualidade na educação de enfermagem. Fatores que deram 
origem a vários projetos prioritários, alguns de responsabilidade direta da Comissão e outros de competência direta de organizações ou de instituições integrantes de esta comissão, de esta maneira, a Comissão tem ingerência unicamente como instância coordenadora, assessora e integradora dos esforços destes grupos.

\subsection{OS HOSPITAIS COMO ORGANIZAÇÕES BUROCRÁTICAS: AMBIENTE DE TRABALHO DA ENFERMAGEM.}

No Sistema Nacional de Saúde, dentro de sua rede de organizações para o atendimento à saúde, o hospital ocupa o ápice da pirâmide de serviços, sendo que, ao seu redor gravitam clínicas, centros de saúde, consultórios e outros. O hospital representa um dos principais organismos integrantes do complexo médico social oferece à população o serviço básico de atendimento médico, colabora direta ou indiretamente, segundo a sua capacidade de localização, em ações complementares e individuais de promoção e proteção da saúde, também dentro de seu âmbito de influência, representa uma organização de formação e treinamento de profissionais médicos, enfermeiros e técnicos, assim como, de investigação na esfera biomédico-social.

Define-se o hospital como a estrutura onde indivíduos com alterações do seu estado de saúde permanecem por um período de tempo para receber tratamento e cura, incluindo, tratamentos internos e externos. Sob o conceito de organização "o hospital é um conjunto de recursos de diversas índoles, que unidos em processos conjuntos, inter-relacionados, especializados e interdependentes, permitem oferecer serviços de saúde às pessoas que os requeiram" (YAÑEZ, 2003).

\subsubsection{Evolução da organização hospitalar}

A palavra hospital deriva do latim Hospitium lugar de hospedagem, hospitalis é um adjetivo relativo de hospitum, que significa hospital. Tem origem no século 3000 a.C. com instituições denominadas Xenodoquium, lugares destinados à atenção dos doentes e feridos de 
origem estrangeira. $\mathrm{Na}$ época Romana, se identificam os Valetudinarium, onde eram atendidos os escravos, soldados e gladiadores. Na época Cristã, surgem os hospitais (Hospes: hóspede), como instituições onde os doentes eram internados (padecere: o que sofre) para receber atendimento para sua doença (ELIZONDO, 1998).

Já, na Idade Média, os hospitais religiosos se fortalecem e orientam suas atividades ao problema das epidemias, comuns naquelas épocas, e ao atendimento de peregrinos que atravessavam pelas diferentes regiões. Durante o Renascimento, a funcionalidade dos hospitais melhora com o aparecimento e desenvolvimento de novos conhecimentos. No final do século XIX, com a Revolução Científica, os hospitais modificam suas estruturas, seus processos e, portanto, mostram ações e resultados de qualidade (ELIZONDO, 1998).

Foucault (1981) considera que o hospital, como instrumento terapêutico, aparece no final do século XVIII. A consciência de que o hospital pode e deve ser um local destinado a curar aparece claramente em 1780, mostrando-o como uma nova prática, na qual a visita, a observação sistemática e comparada é uma constante das atividades diárias. Estas ações contribuem com a construção do conhecimento e legalização do atendimento das pessoas que eram tratadas nessas instituições. Ainda, Foucault, em seu livro a Micro-Física do Poder, refere que esse avanço na Europa foi possível graças à iniciativa de alguns observadores que viajavam com o fim de conhecer o funcionamento dos hospitais. Entre elas destaca a viagem de Howard que percorreu diversos hospitais, presídios e lazaretos da Europa, entre 1775 e 1780 (FOUCAULT, 1981). Uma das grandes contribuições foi a consideração da arquitetura das organizações hospitalares, referente à distribuição dos espaços de uma forma mais adequada, de maneira a contribuir com a ventilação e proteção ambiental. Foucault (1981) admite a hipótese do duplo nascimento do hospital, uma com as técnicas de poder disciplinar e a outra com a intervenção médica entre o meio médico-arquitetônico. Assim, apresentando algumas características: 
- Referente à localização, descrito como um local deprimente, em pleno coração da cidade, como um lugar onde as pessoas eram colocadas no momento da morte e, onde, não era possível a transmissão por difundir ar e água contaminada. Era necessário que, o espaço onde estivesse situado o hospital, correspondesse a um terreno sanitário e que o espaço, no interior do hospital, fosse disposto para o cliente com certa comodidade e tratamento individualizado.

- Referente à transformação do sistema de poder dentro do ambiente hospitalar, até meados do século XVIII, era exclusivamente religioso, raramente por leigos. Os religiosos eram os responsáveis por atender, tanto aspectos religiosos, os relacionados com a salvação da alma, como alimentação das pessoas internadas. O médico era chamado para os mais doentes, para justificar a causa da morte e em menor necessidade para uma ação de cura. Como resposta à mudança de paradigma, o hospital concebido como um espaço de cura, passa a ser entendido como um instrumento terapêutico. O médico passa a ser o principal responsável do componente médico-arquitetônico hospitalar, assim, passando a representar a máxima hierarquia dentro do hospital. Estabelecem-se rotinas como a visita médica diária para todos os pacientes, tornando-se um ritual realizado por um grupo de pessoas entre os quais se destaca a presença do aluno de medicina e a chefe de enfermagem, entre outras. Surgem os regulamentos escritos especificando, claramente, o papel de cada membro da equipe de atendimento dentro do hospital (FOUCAUTL, 1981).

- Referente à organização, nasce o sistema de registro dos acontecimentos dentro do hospital, como a identificação dos pacientes, identificação do histórico dos pacientes, identificação dos leitos, registro de internação e alta, de diagnósticos médicos, assim como, os registros dos cuidados de enfermagem, de farmácia e anotações médicas diárias depois de realizada a visita médica, entre outras. O hospital tornou-se um centro educativo, centro de conhecimento para a formação e transmissão do saber, com disciplina e constância, para os cuidadores, principalmente médicos e enfermeiras, assim, ressaltando as melhores curas e 
evolução de cada paciente. O ser humano se converte no centro de observação, no objeto do saber e da prática médica (FOUCAULT, 1981).

Com a aquisição de novos conhecimentos e o desenvolvimento tecnológico o hospital foi se tornando cada vez mais complexo, oferecendo uma ampla variedade de serviços e especialidades acompanhadas de tecnologia, e da multidisciplinaridade que exigira um processo de gestão baseado no controle rígido e na previsibilidade do comportamento humano (HINICH, 1990).

Na América do Norte, Trevizan (1988) refere que a Associação Americana de Hospitais foi criada com o fim de encontrar soluções aos complexos e variados problemas, nestas instituições, seus diretores consideravam conveniente encontrar soluções a situações semelhantes nos diferentes hospitais, assim, a finalidade foi solucionar, variados e complexos conflitos, para os quais, recorreram ao apoio nas ciências administrativas e organizacionais.

Foi criado o Colégio Americano de Administradores de Hospitais, o qual foi uma resposta à necessidade de formar administradores especialistas para a organização e funcionamento dos hospitais. Em 1934, com nível de pós-graduação, se estabeleceu a primeira Escola de Administração Hospitalar na Universidade de Chicago, cujo objetivo era estudar os estilos de direção de hospitais e facilitar o gerenciamento dos centros hospitalares, com o paradigma funcionalista taylorista e fayolista (TREVIZAN, 1988).

Ruiz de Esparza (1984) considera que a formação dos administradores para hospitais teve sérias complicações, nessa época, os administradores, em sua maioria, eram administradores, e não médicos, portanto, orientados à direção de processos de engenharia inspirados por Taylor e Fayol em organizações industriais. Profissionais direcionados ao trabalho por tempos e movimentos, trabalhos em série, marcada especialização e hierarquização, entre outros atributos, praticados dentro das empresas, distantes do ambiente trabalhista no hospital, organização orientada para oferecer atendimento a seres humanos, 
portanto, ações difíceis de padronizar e produzir em série. Diferenças que geraram freqüentes choques de atitudes e significados.

Enquanto, nos Estados Unidos se difundia o movimento da administração científica, na Alemanha se iniciava um dos mais fecundos movimentos de idéias, o estudo da organização burocrática (WEBER, 2005) constituindo-se no pilar da expressão dos conhecimentos e do funcionamento das organizações.

O México teve duas influências principais: a européia pela civilização espanhola e a americana. A espanhola deu o mesmo paradigma que descreve Foucault, houve intervenção dos religiosos quem sob o conceito medieval de "Caridade", proporcionaram os primeiros serviços hospitalares, com a velha tradição de ser ao mesmo tempo, hospedarias, orfanatos, asilos e sanatórios. Ao mudar o cenário político, no México, ao início do século XIX, a consciência médica motivou o governo a assumir o controle das instituições de saúde e não deixá-las às organizações religiosas. Conceitualmente passou de instituição de caridade para instituição de beneficência e depois para hospital assistencial de origem estadual centralizado. Em sua fusão com os novos modelos e conhecimentos administrativos, o hospital-empresa, se diferencia entre as fronteiras públicas e privadas. Deste modo, os conceitos de direitos humanos, caridade e assistência médica se elevaram ao conceito de "Beneficência Pública", em acordo com as mudanças sociais e políticas originadas pelo movimento de independência em 1810 (RUIZ DE ESPARZA, 1984).

A influência norte-americana do século XX, deixa evidenciar a era moderna do hospital, o desenvolvimento tecnológico, econômico e político do país. Como resposta foi inaugurado, pelo Presidente Porfírio Díaz, o primeiro hospital do país: o Hospital Geral do México.

Em 1906, inicia a historia do hospital moderno. Entre outras, se inicia a formação moderna dos profissionais de enfermagem e da área de saúde do México. Na enfermagem, surge a primeira Escola de Enfermagem do país, inaugurada formalmente em três de outubro de 1907. Como sede no Hospital Geral de México. 
As características do hospital geral: organização de sistema aberto, que opera em diferentes meios, responde a uma necessidade, recebe insumos próprios para o desenvolvimento de seus processos e emite serviços dentro de seu âmbito ou especificidade. Seus insumos ou recursos são, em sua maioria, elementos dinâmicos, importantes no momento de assimilá-los ou operá-los, o talento humano, o capital, a infra-estrutura física, a tecnologia, os conhecimentos e habilidades, sua configuração estratégica, entre outros. Tudo isso, convertido em resultados depois de uma adequada combinação dos especialistas que trabalham na organização. Seus principais recursos estão representados pelos profissionais e suas ações dirigidas a tarefas concretas que, com o passar do tempo e com a capacitação recebida, se convertem em novos especialistas.

O talento humano, como o da enfermagem, possui inumeráveis potencialidades, intelectuais ou pragmáticas, que devem ser encaminhados de maneira adequada, com motivação, estímulo, e recompensa. Os anteriores recursos se envolvem em diferentes processos, donde se integram e se transformam através de elementos técnicos, unidos por atividades interpessoais e de comunicação entre grupos de trabalho interdisciplinares. Ai radica em grande parte, a eficiência dessas organizações. Dessa forma, tem-se como final a conquista de uma série de resultados, observados através dos diferentes serviços prestados, utilidades, satisfação, posicionamento, inovação, tecnologia apropriada, rentabilidade, utilidade social, trabalho e desempenho, entre outros (CORDERA; BOBENRIETH, 1992).

A situação atual da enfermagem requer que, no hospital, se avalie e especifique claramente a sua missão frente a um contexto dinâmico e mutante. Para consolidar-se como empresa requer desenvolver um controle sobre cada atividade desenvolvida. Exercer autocontrole, até nos mínimos detalhes. Por esta razão, ressaltamos a confiança e a lealdade recíproca, de inteligência e raciocínio aplicado a cada ação, de eqüidade, participação e 
promoção, de formação de colaboradores, capacitação permanente, comunicação direta e congruência, tudo isso direcionado ao crescimento.

Assim como em outras organizações o hospital não pode mostrar desorganização do sistema. Esta é requerida para manter o equilíbrio entre as relações de quem dirige e quem colabora. A funcionalidade e não funcionalidade está no balanço entre os critérios de poder, econômicos, de produtividade e do comportamento humanos.

Além dos conceitos anteriores, o hospital assume uma configuração ou estrutura própria, a mais adequada para o cumprimento de sua missão e objetivos. Evoluem por diferentes etapas de acordo com seu tamanho, tempo transcorrido, desde a criação até a apresentação de situações de crises, os períodos de reestruturação e os serviços oferecidos.

Ruiz de Esparza (1984) refere que as crises mais freqüentes estão relacionadas com a liderança indefinida, a ausência de planejamento, a busca de uma maior autonomia, a crise derivada do controle, as comunicações informais e os processos repetitivos que não contribuem com a eficiência das atividades. Para todas elas, a instituição vai gerando com maior ou menor agilidade, as respostas ou soluções adequadas.

Cada hospital assume um tipo de estrutura que reflete os valores, políticas e alcances que pretende lograr. Mintzberg (2004) em seu livro “A estrutura das organizações” descreveu cinco configurações naturais com elementos constitutivos comuns entre elas, como:

Cúpula estratégica ou profissional de direção, um núcleo operativo ou colaboradores, os mandos intermediários, o staff ou linhas de apoio, a tecno-estrutura ou mecanismos reguladores e supervisores de situação, que estão presentes nos hospitais. Conformando-se assim:

Estrutura simples, jovem, onde a direção é assumida diretamente pela cúpula, requerendo poucos assessores, mandos intermediários e mecanismos de controle. Consta-se de um diretor, subdiretores e assessores. Burocracia mecânica, na qual a regulamentação do 
trabalho é o elemento central e por isso requer de uma grande estrutura técnica que delimita padrões requeridos, fiscaliza processos, controla e regula toda ação dos colaboradores que carecem de capacidade para inovar e participar ativamente. Tecnocracia verificada por meio da regulamentação.

Burocracia profissional, é diferente da anterior, a coordenação se realiza com base nos conhecimentos que possuem os colaboradores, ou seja, no núcleo operativo. São instituições mais autônomas, o trabalho é realizado em grupos de trabalho auto-regulados, com especialistas que colaboram para o objetivo comum. Realizam procedimentos, mais ou menos, padronizados, não rígidos, adaptando-se a meios estáveis e complexos. Típico exemplo dos hospitais.

Estrutura divisória. A coordenação surge do rendimento das diferentes unidades. São conformadas áreas paralelas, entre si, com bastante grau de autonomia sobre os produtos ou serviços diferentes, por exemplo, áreas de hospitalização e consulta externa.

Adocracia ou meritocracia. Representada por característica de instituições mais complexas, com núcleos altamente especializados e cuja coordenação surge graças à adaptação mútua de equipes interdisciplinares criativas, inovadoras e altamente competitivas. Seu trabalho gira em volta de projetos específicos, como costuma suceder em instituições dedicadas à investigação. É possível que uma instituição hospitalar adquira estas características.

Em relação às funções do hospital moderno Paganini (1999) acrescenta:

- Atenção médica contínua. Concentra uma grande quantidade de recursos de diagnóstico e tratamento, no menor tempo possível, para reintegrar rapidamente o paciente ao seu meio familiar; 
-Atenção médica integrada. Constituindo um período intermediário dentro de uma rede de serviços de complexidade crescente, sendo que, a vinculação do estabelecimento a uma rede, garante a disponibilidade de todos os recursos para a solução dos casos;

-Área programática. O estabelecimento tem uma área de influência na qual oferece seus serviços a determinada população e por meio dela são avaliados os resultados de suas ações;

-Efeitos dos programas de saúde: o estabelecimento também atua executando programas preventivos e de promoção da saúde, impulsionados pela autoridade sanitária (PAGANINI, 1999).

Os seres humanos são os eixos do hospital e, como tal, a garantia da qualidade é, em termos de eficiência, uma necessidade e, em termos éticos e morais, uma obrigação. Todas as instituições hospitalares, pela sua missão em favor do Homem, devem preocupar-se pela melhoria permanente de suas ações, em prol da integração harmônica das áreas médicas, tecnológicas, administrativas, econômicas, assistenciais e, se for o caso, das áreas docentes e de investigação.

No México, alguns critérios gerais são considerados para o estabelecimento de hospitais gerais, esses devem estar localizados em pontos estratégicos das regiões, atendendo às condições de comunicação e à disponibilidade dos recursos de saúde, em localidades de 50.000 a 100.000 habitantes. Oferecem uma cobertura para até 120.000 habitantes, em sua área de responsabilidade. A estrutura arquitetônica deve estar de acordo com as normas de construção emitidas pela Secretaria de Saúde, sendo recomendados os edifícios de tipo vertical, que permitam o transporte integral do paciente e o maior aproveitamento de recursos. O equipamento se ajusta, também, às normas correspondentes, sendo conveniente insistir que os recursos materiais utilizados deverão assegurar as condições ótimas de manutenção e a existência suficiente de alimentação. Os pacientes serão internados somente em leitos 
contemplados dentro das quatro especialidades básicas: cirurgia, ginecologia-obstetrícia, clínica médica e pediatria (MÉXICO, 1987).

Considera-se que um hospital geral deva ter em média 120 leitos. Este assume a responsabilidade das atividades referentes ao restabelecimento da saúde, atendendo danos de media complexidade. Para o cumprimento dessa responsabilidade deve contar com recursos humanos e tecnológicos especializados para atender e resolver os problemas médicocirúrgicos que representem aproximadamente $15 \%$ da demanda de atenção médica, não passíveis de solução atenção básica. Nesses hospitais, a atenção é de caráter ambulatorial e de hospitalização.

A partir do ponto de vista de "Atenção Restauradora", as atividades devem compreender o diagnóstico rápido, o tratamento especializado, e a reabilitação. Em relação à “Atenção Preventiva", está amplamente representada por atividades de promoção à saúde, primordiais na comunidade, e devem ser estimuladas em forma importante em uma unidade hospitalar, sem abandonar aquelas atividades que, tradicionalmente, tem-se desenvolvido no interior dos hospitais sob o nome de Vigilância Epidemiológica, Controle de Doenças Transmissíveis e Prevenção. A formação e desenvolvimento dos recursos humanos para a saúde, assim como, a investigação deve ser estimulada sem interferir nas atividades assistenciais, já que essas são prioritárias.

Em relação à organização e funcionamento administrativo de um hospital pode-se dizer que os objetivos de um hospital geral são oferecer atenção médica preventiva, curativa e de reabilitação à população de sua área de responsabilidade por meio dos serviços de urgências, auxiliares de diagnóstico e tratamento, consulta externa e hospitalização. Além de participar na formação e desenvolvimento de recursos humanos para a atenção à saúde e contribuir nos programas de investigação básica, clínica e sócio-sanitário do Setor Saúde. 
Referente a estrutura orgânica, dos hospitais gerais do México, a direção do Hospital, está composta pele Diretor geral, Subdiretor Médico, Subdiretor Administrativo, Chefe de Enfermagem e Assistente de Direção. Para a tomada de decisões técnicas e administrativas, a direção do hospital se apóia nos órgãos consultivos: Patronato, Conselho Técnico e Comitês.

Os hospitais constituem entidades sociais relativamente permanentes. Este atributo lhes permite continuar operando, ainda que mude a direção. Devido a esta continuidade é possível predizer, com maior exatidão, o que uma organização poderia fazer ainda, independente, das mudanças dos profissionais considerados chave. O hospital tem características de organização burocrática, é planejado para administrar tarefas estáveis e rotineiras, o que fundamenta a eficiência da organização.

As organizações hospitalares são reconhecidas, junto às universidades, como as organizações mais complexas, pela variedade de especialidades, tecnologias e profissionais com variados níveis de preparação e especialização, entre outros elementos. Seus objetivos secundários poderão encontrar-se algumas vezes em oposição uns como os outros. A especialização é outro aspecto básico das organizações hospitalares. De modo geral, por serem organizações de alta tecnologia e possuírem uma grande diversidade em suas operações, requerem habilidades muito especializadas para que essas organizações alcancem seus objetivos (THOMPSON, 2002).

A característica chave da organização hospitalar, é que possuem estruturas. Todas as organizações dispõem de um conjunto de meios prescritos e regularizados para coordenar suas diversas atividades laborais, como anteriormente mencionado. Isso se torna essencial para o alcance dos objetivos da organização. A estrutura é de grande utilidade, não só para especificar as relações entre as diferentes atividades laborais, como também, para definir as inter-relações de autoridade. A hierarquia é motivo de preocupação para os membros da 
organização, e consiste em conglomerados de indivíduos e grupos, que se inter-relacionam para o alcance do principal objetivo: recuperar a saúde do cliente (THOMPSON, 2002).

O Diretor do Departamento de Enfermagem está subordinado à subdireção médica ou, dependendo do caso, à direção geral, sendo o responsável pelos serviços de supervisão das atividades da equipe de trabalho de enfermagem.

\subsubsection{Modelo burocrático do hospital}

A palavra burocracia vem de bureau (oficina) e kratos (poder). Começou a ser utilizado na França no século XVIII para definir os cargos de funcionários do governo que originavam seus próprios interesses, a criação de grupos de trabalho e novos empregos, tendo como essência básica a hierarquia, a especialização, a formalização e a padronização (MORENO, 2003).

A burocracia é uma forma de organização humana que se baseia na racionalidade, ou seja, a adequação dos meios aos objetivos (fins pretendidos, com o fim de garantir a máxima eficiência possível para o alcance desses objetivos). As origens da burocracia, como forma de organização humana, são bastante antigas. Não obstante, a burocracia, como concebida atualmente, como base do sistema moderno de produção, se originou nas mudanças religiosas ocorridas depois do renascimento. Conforme afirma Weber (2005) o sistema moderno de produção, eminentemente racional e capitalista, não se originou nas mudanças tecnológicas nem nas relações de propriedade, mas a partir de um novo conjunto de normas sociais e morais denominadas ética protestante: "o trabalho duro e árduo como dom de Deus, a economia e o ascetismo que proporciona o re-investimento das rendas excedentes, em vez de gastá-las e consumi-las em símbolos materiais e improdutivos, em nome da vaidade e do prestígio" (WEBER, 1965).

Weber (2005) deduziu que o capitalismo, a burocracia (como forma de organização) e a ciência moderna constituem três formas de racionalidade que surgiram das mudanças 
religiosas ocorridas, inicialmente, nos países protestantes - como Inglaterra e Holanda - e não em países católicos. Existem assim grandes semelhanças entre o protestante, principalmente o calvinista, e o comportamento capitalista.

Marx (1979), em sua obra A crítica da Filosofia do Estado, disse que a burocracia é o aparelho administrativo do Estado que formaliza a dominação por meio de um marco legal e formal, decisões e controle centralizado, divisão do trabalho e remuneração fixa. Também, assinala que a burocracia nasceu da decadência do regime feudal e da consolidação da monarquia absoluta e se fortaleceu com todas as revoluções, pois estas a empregaram, em todos os casos, como o instrumento da classe dominante.

Weber (1998) refere que as crenças que legitimam o exercício do poder existem tanto na mente do líder como na dos subordinados. Tais crenças determinam a relativa estabilidade da dominação e refletem as diferenças básicas entre os diversos sistemas de dominação. Para estabelecer a tipologia de sua autoridade, Weber (1998) não se baseia nos tipos de poder empregados, senão na autoridade e na sua legitimação. Segundo Mouzelis e Weber (1965) a legitimação e o aparelho administrativo são os dois principais critérios da tipologia weberiana.

Segundo Weber (1965) a burocracia não seria considerada como um sistema social, mas, como um tipo de poder (CHIAVENATO, 2006, p. 453):

“[...] a autoridade representa o poder institucionalizado e oficializado com a probabilidade de que uma ordem específica seja obedecida. O poder implica a potência para exercer influência sobre outras pessoas. Segundo Weber (1965), poder significa a probabilidade de impor a própria vontade dentro de uma relação social, ainda contra qualquer forma de resistência, e qualquer que seja o fundamento dessa probabilidade. Portanto, o poder é a possibilidade da imposição da vontade de uma pessoa na vontade da outra. A autoridade proporciona poder: ter autoridade é ter poder...ter poder não sempre significa ter autoridade. A autoridade depende da legitimidade, que é a capacidade de justificar seu exercício. A legitimidade é o motivo que explica porque determinado número de pessoas obedecem as ordens de alguém, conferindo-lhe poder. Essa aceitação essa justificação do poder, se chama legitimação. A autoridade é legitima quando é aceita. Se a autoridade proporciona poder, o poder conduz à dominação. A dominação significa que a vontade manifesta (ordem) do dominador influi na conduta de outros (dominados), de modo que o conteúdo de ordem, por si mesmo, transforma em normas de conduta (obediência) para os subordinados [....]". 
Entretanto, Foucault (1981), um dos maiores pensadores do século XX, em sua teoria de Micro-física do Poder, explica que o poder não está exclusivamente referido ao aparelho denominado Estado, o poder tem uma multiplicidade de formas na sociedade, ao que chamava a trama de poder microscópico, capilar. Com ele se cria, também um diagnóstico da multiplicidade de opressões, sobretudo, para os mais marginalizados como os detentos, doentes mentais, minorias sexuais, imigrantes, jovens, entre outros. O poder se situa no próprio tecido do corpo social, e não sobre o corpo social penetrando na vida cotidiana e, por isso, o caracteriza como micro-física do poder (FOUCAULT, 1981).

“[...] Micro-física do poder...significa um deslocamento do espaço de análise relacionando com o nível em que este se efetue. Menciona dois aspectos intimamente, ligados, na medida da consideração do poder, uma em suas extremidades, e a outra a que se dá no molecular, ou seja, no âmbito central. As atenções a suas formas locais, a seus últimos alinhamentos têm como correlato à investigação dos procedimentos técnicos do poder que realizam um controle detalhado, minucioso do corpo como gestos, comportamentos, hábitos discursos $[\ldots]^{\prime}$.

Realidades distintas, mecanismos heterogêneos, esses dois tipos específicos de poder, se articulam e obedecem a um sistema de subordinação que não pode ser traçado sem que se considera a situação concreta e o tipo particular de intervenções. Isto é, poderes existentes na periferia e no centro do aparelho denominado Estado. O poder não necessariamente é criado pelo Estado, nem nasce fora dele. Os poderes se exercem em níveis variados e em pontos diferentes da rede social complexa, o qual se reflete em qualquer organização como é a de um hospital.

Entre Foucault e Weber, aparentemente não há pontos de coincidência. Foucault considera que o poder se encontra em todo o tecido social e Weber considera que o poder está no aparelho jurídico administrativo. No presente estudo, se considera uma mistura das duas formas que concebem Foucault e Weber em toda a organização.

Entre os fatores que favorecem o desenvolvimento da burocracia se ressalta $o$ desenvolvimento tecnológico. A superioridade técnica, em termos de eficiência, requer do 
tipo burocrático de administração como força autônoma interna para impor seu predomínio. Weber (2005) disse que "a razão decisiva da preeminência da organização burocrática foi sempre e unicamente sua superioridade técnica sobre qualquer outra forma de organização". O desenvolvimento tecnológico permitiu que as tarefas administrativas, destinadas a supervisar e controle, evoluíssem. Assim, quando os sistemas sociais cresceram, as grandes empresas passaram a produzir em massa. No entanto, nas grandes organizações existiu a necessidade crescente de controlar e prever seu funcionamento, até o mínimo detalhe, garantindo a previsibilidade como acontece nas organizações hospitalares. A tecnologia se converteu em um atributo valioso na época moderna do hospital, e com a aparição e desenvolvimento da revolução científico-tecnológica na medicina, se observa em várias áreas alguma deteriorada como na relação médico cliente, por exemplo, em que ocorre um abandono crescente da entrevista, do exame físico e do conhecimento clínico, assim como, uma utilização e dependência irracional, excessiva pelo uso da tecnologia na prescrição dos exames de laboratório, de imagem, ultra-som e ressonância magnética. Fato representado por um grande número de médicos, que configuram um verdadeiro fetichismo da tecnologia. Tudo isso se tornou importante e sensível, com implicações éticas na prática médica, observando-se a utilização irracional da tecnologia médica aplicada ao diagnóstico e tratamento. Por exemplo, Bernard Lown, um destacado cardiologista norte-americano e premio Nobel, em 1995 referiu que "o sangue do paciente era encaminhado ao laboratório antes de terminar de falar com ele e muito antes de tocá-lo” (WEATHERALL, 1997).

O domínio da tecnologia sobre as ações do homem e, do homem como servidor da tecnologia, tem uma elevada conotação ética. Fato que foi citado e analisado por Marx já em 1979, referindo-se às questões relativas à alienação do homem e do trabalho chamando-o de "fetichismo da mercadoria" - dois conceitos básicos da economia, da filosofia e da sociologia marxistas. Marx (1979) viveu na época do capitalismo de livre concorrência, quando se 
assistia a um aumento na produção de todo tipo de mercadorias nunca antes vivenciado pela humanidade. Esta independência relativa dos produtos na forma de mercadoria mascarava, em milhões de pessoas, sua origem no trabalho humano, conferindo-lhe um valor intrínseco, irreal e convertendo-as, ao dizer de Marx, em objeto de uma adoração quase religiosa, um fetiche. A tecnologia passou a ter um poder importante no hospital.

\section{2,3 Características de orientação burocrática nos hospitais}

Os hospitais são instituições eminentemente técnicas. Por uma parte, é privilegiado o grau de competência específico e, por outra, requer relações estruturadas hierarquizadas, decisões previsíveis, bem determinados e uma "meritocracia“. É uma entidade altamente padronizada identificada dentro do modelo burocrático de Weber.

A evidência da orientação burocrática, dos hospitais gerais da cidade do México do Distrito Federal, permite deduzir o seu ajuste dentro das características do modelo weberiano, que é analisado com base nas considerações de Chiavenato (2006): a regulamentação considera que a organização está baseada em normas e regulamentos previamente estabelecidos por escrito, buscam cobrir todas as áreas da organização, prever todas as situações possíveis e enquadrá-las dentro de um esquema previamente definido.

Algumas características se descrevem segundo Weber (1998) que considera as comunicações, onde as regras, as decisões e as ações administrativas formuladas devem ser registradas, favorecendo a interpretação unívoca das mesmas. A divisão do trabalho em que cada participante desempenha um cargo e funções específicas em um campo de competência e responsabilidade específica. No que se refere às relações interpessoais, considera-se a igualdade de tratamento para todos os empregados de acordo com seu papel e assim, cada cargo inferior deve estar sob o controle e supervisão de um superior, sendo que, nenhum cargo fica sem controle ou supervisão. Aponta para os procedimentos, em que a organização fixa regras e normas técnicas para o desempenho de cada cargo. As regras e normas técnicas 
regulam a conduta de quem ocupa cada cargo. As competências técnicas determinam a seleção das pessoas que se baseia no mérito e não em preferências pessoais. E, com isso a admissão, transferência e promoção de funcionários, é baseada em critérios de avaliação e classificação válidos para toda a organização. Entende-se por propriedade de maneira separada à administração. O dirigente é um profissional especializado em administração; cada funcionário da organização tem características de especialista, recebe uma remuneração determinada e ocupa um cargo. Acontece a previsão do comportamento frente à distribuição de atividades desenvolvidas em termos de cargos e funções, e não das pessoas envolvidas. Quando surge alguma possibilidade de mudança dentro da organização, ela representa perigo para a segurança e tranqüilidade. A mudança é indesejável.

O atendimento ao cliente e ao público, é realizado de maneira padronizada, de acordo com os regulamentos e rotinas internas. Isso faz com que o cliente fique irritado com a pouca atenção prestada e com a falta de sensibilidade com a qual, refere ser tratado quando expõem seus problemas particulares e pessoais. As decisões são previsíveis e o processo decisório, ao ser impessoal exclui sentimentos irracionais como amor, ira e preferências pessoais, elimina a discriminação pessoal. Quem toma as decisões é aquele que possui a mais elevada categoria hierárquica, independentemente de seu conhecimento.

As organizações hospitalares são orientadas, principalmente, ao cumprimento das tarefas. Johansen (1996) refere que, as ações, se ajustam a padrões, normas, manuais, regras, procedimentos e regulamentos é um ambiente que altera os pontos de referencia dos trabalhadores que se vêem privados de identidade chama Durkheim anomia dos trabalhadores.

A orientação dos hospitais gerais, da cidade de México, Distrito Federal ao modelo burocrático, assemelha-se este fato. Os críticos costumam se referir a duas características principais da burocracia: o caráter inadaptável que favorece a estabilidade, tenacidade e previsibilidade, a limitada espontaneidade, a liberdade e a realização pessoal. Estas duas 
críticas centram-se na rigidez e na disciplina. Perrow (1998) considera uma terceira critica: o mecanismo, tanto nas sociedades capitalistas como não-capitalistas, com a função de centralizar o poder na sociedade, e de legitimação ou de disfarce desta centralização. A burocracia é uma ferramenta social que legitima o controle de muitos por poucos, apesar do aparelho formal de democracia e este controle tem gerado um poder social não regulamentado, nem percebido. Este poder implica muito mais que o simples controle dos trabalhadores.

\subsection{A ENFERMAGEM NO MÉXICO}

A Enfermagem é uma profissão. A palavra profissão vem do latim professio que significa professar, exercer uma ciência ou uma arte, escolhida com inclinação voluntária. Este significado é bem colocado na Enfermagem: cuidar de pessoas sadias ou doentes.

No México é uma profissão de grande importância para a sociedade, pela sua capacidade demonstrada, no cuidado e na solução de problemas de saúde com ênfase humanística, no cuidado de pessoas sadias ou doentes, dentro do ambiente hospitalar, nos centros de saúde, no domicílio, nas escolas, nos ambulatórios, asilos, fábricas, entre outros campos de ação, onde a Enfermagem se desenvolve.

O papel da Enfermagem tem uma importante contribuição no SNS, nos programas de saúde nacionais, estaduais e institucionais, e além as profissionais da enfermagem estão presentes em alto porcentagem nas organizações de saúde onde cumprem funções assistenciais, docentes, administrativas e de investigação. Com as grandes demandas da população, tecnológicas e complexo atendimento à saúde, o grupo de enfermagem tem requerido desenvolvimento profissional. Especializações se tornaram necessárias em diferentes ramos da medicina moderna e, como educadora de saúde, na orientação, informação e contribuição com hábitos saudáveis para a vida. 
O profissional de enfermagem tem destacando como administrador de serviços de enfermagem nas instituições do SNS. No entanto, seus aportes na investigação ainda são incipientes, mas têm trabalhado na sistematização do conhecimento, desenvolvendo conceitos, critérios, padrões e juízos técnicos em prol do avanço da Enfermagem, propriamente dita, e das ciências de saúde, sempre em benefício da humanidade. A Enfermagem está evoluindo graças à influência intrínseca de seu próprio processo de maturidade como disciplina científica, isto é, encontra-se em constante evolução como conseqüência de mudanças de paradigmas. Os desafios que enfrenta a profissão são inumeráveis. A seguir apresenta-se uma breve descrição da formação, evolução e prática social da Enfermagem.

\subsubsection{A formação em Enfermagem}

A criação da enfermagem como profissão, no México, respondeu à necessidade do cuidado hospitalar dos pacientes, como resultado de dois fatores principais: a expulsão das ordens religiosas, que culminou em 1874, com a saída das Irmãs de Caridade e com o desenvolvimento da medicina científica nos grandes hospitais que foram fundados durante o século XX.

No México, os médicos identificaram a necessidade de formar um grupo de trabalhadores que se encarregassem das ações do cuidado direto com o paciente, surgindo, em 1907, a primeira Escola de Enfermagem (BERMEO; GUZMÁN, 1995), tendo como sede, o Hospital Geral do México. Foi regulamentado que a faculdade seria cursada em dois anos. As funções que desempenhavam as enfermeiras nos serviços incluíam os cuidados aprendidos, entre eles, atividades de caráter administrativo, por exemplo, controle de material e equipamento, tarefa que consumia o tempo do começo ao fim do período de trabalho do dia (PÉREZ LOREDO, 1986). 
Do exposto anteriormente, se desprendem as características que marcaram a origem da profissão de Enfermagem: exclusiva para mulheres, auxiliar do médico, com formação rígida, disciplinar, eminentemente técnica, centrada na doença e, com programas acadêmicos elaborados por médicos, os quais orientaram à carreira ao saber "básico" e ajudar ao médico a fim de exercer um eficiente cuidado dos pacientes (BECERRIL, 2005, p. 65).

“[...] Os programas deste primeiro plano de estudos universitários, elaborados por médicos, definiram o papel da enfermeira e os conhecimentos que deviam adquirir. O doutor. Lamicq, professor da escola desde a sua inauguração no Hospital Geral e autor de um dos primeiros manuais sobre enfermagem, assinalava nesse texto: é absolutamente necessário que perceba bem (a enfermeira) qual é seu papel, que não é outro senão o de ajuda ao médico, aplicando estrita e sabiamente, suas prescrições e pondo, ademais, de si o quanto possa para fazer menos sacrificante a doença ao paciente, evitando ou impedindo tudo o que possa ser prejudicial a ele $[\ldots]$...

Com relação ao currículo, em 1946, se destaca o aumento do tempo de estudo para três anos, incorporando-se novas disciplinas. Em 1947, foi estabelecida uma reforma ao projeto educativo de Enfermagem, dando-se ênfase ao desenvolvimento da base científica da medicina, ao conteúdo humanista, práticas avançadas como enfermagem cirúrgica e fisioterapia. Assim, também, se estabelecem os primeiros laboratórios e, na especialização de obstetrícia, se ampliam as práticas de maternidade. É também incorporada ao currículo a disciplina de Medicina Preventiva (PÉREZ LOREDO, 1986).

Outra reorganização curricular surge entre 1949 e 1950, promovendo-se uma ampliação de conteúdos para reforçar o conhecimento das doenças infecciosas e patologias emergentes. Fortalece-se a idéia da enfermagem rural e se desenvolve a capacidade educadora.

A escola de enfermagem logra relativa autonomia acadêmica, começando a ser dirigida e liderada, pelas próprias enfermeiras, que começam a se destacar como professoras nas escolas, participando como palestrantes em eventos acadêmicos, destacando-se também, como administradoras, tanto no campo educativo quanto nos serviços. Já, como professoras ou como parte da direção organizacional, as enfermeiras promoveram a resolução das 
necessidades do nível universitário, dessa forma, em 1967 foi incluído e aprovado o currículo para a Licenciatura em Enfermagem e Obstetrícia, iniciado em 1968 (NAJERA, 1990).

Simultaneamente, surge um novo paradigma, com necessidades sócio-médicas e são criados alguns cursos de pós-Técnicos (se denomina pós-técnico ao estudo que se faze depois de estudar uma carreira técnica em um período de dez a doze meses) como, a especialização em Cardiologia, Pediatria, Saúde Pública, Administração e Supervisão dos Serviços de Enfermagem, Docência e outros (GARCÍA; MONROY, 2004).

A Enfermagem teve um processo lento de desenvolvimento, durante 100 anos (19072007), enfrentou crises referentes a sua natureza de arte e ciência do cuidado à vida. O processo de reconhecimento da necessidade de sua formação, como nível superior foi longo, mas, é recente sua parcial autonomia acadêmica e como escola da enfermagem em os últimos vinte anos, mas os hospitales segue sendo uma profissão dependente das médicas.

Em relação ao desenvolvimento das escolas, Espino et al. (1997) realizaram um estudo de avaliação da educação de enfermagem no México, destacando que as escolas se diferenciam fundamentalmente em dois grupos: públicas e privadas. Nas escolas públicas se encontram agrupadas nas universidades federais e estatais com autonomia acadêmica. As escolas privadas estavam também incorporadas às universidades autônomas ou estatais, os dois grupos são reconhecidas oficialmente pela SEP. As escolas apresentam variedades na formação como nível superior licenciatura, nível médio superior (enfermagem com estudo simultânea ao bacharelado) e enfermagem básica depois da educação fundamental.

A Federação Mexicana de Escolas e Faculdades de Enfermagem relatam que existem no país 600 escolas registradas com as variedades mencionadas e heterogeneidade de currículo. Ainda há escolas que dependem dos hospitais: como as escolas privadas.

García e Monroy (2004) referem que, a partir da inserção das enfermeiras no âmbito universitário, para os profissionais têm uma grande oportunidade, com melhor perspectiva 
dentro da profissão e, portanto, em beneficio da sociedade, pois o atendimento de enfermagem se projeta melhor, a organização e funcionamento do corpo de enfermagem, que passou a ser dirigido por profissionais de enfermagem. As enfermeiras com licenciatura tinham a oportunidade de ingressar a estudos de pós-graduação de outras disciplinas como de: administração, educação, sociologia voltadas a humanidades. Não existia o curso de mestrado de enfermagem e o interesse estava voltado à especialização no cuidado dos indivíduos, família e comunidade. Na década de oitenta, com a declaração de Alma-Ata, se introduziu um novo paradigma para a formação de enfermagem: "saúde para todos" o que deveria ser cumprido mediante a estratégia de Atendimento Primário de Saúde (APS), iniciando-se o curso de mestrado em Ciências da Enfermagem. E na década de noventa, se inicia o planejamento do grau de doutor.

$\mathrm{Na}$ atualidade, embora, todos os esforços de agrupação das escolas de enfermagem, ainda não existe um planejamento curricular nacional, visando a ser produto da unificação de critérios para estabelecer um processo de padronização nacional, de como se deve formar ao profissional de enfermagem em seus distintos níveis acadêmicos, com adaptações a diferentes cenários, segundo a região do país. Permitindo, assim, estabelecer os perfis profissionais e paralelamente, apoiar-se nos órgãos "colegiados", por meio de legislação do exercício profissional. Por não ter isso processos padronização têm uma diversidade na formação acadêmica de enfermagem: licenciatura (programa universitário), nível técnico (programa de três anos de formação), técnicas com especialidade (programas de pós-técnicos de 10 meses) e Auxiliar de enfermagem (Programas de capacitação de seis meses a um ano). Esta diversidade da formação se projeta na prática profissional, onde o favorecido é o mercado de trabalho, pois não há diferença nas funções, sobretudo nos afazeres da licenciada e técnica, pois na prática realizam as mesmas atividades e recebem o mesmo salário. 


\subsubsection{Evolução da Enfermagem do México}

No México, a Enfermagem tem passado por várias etapas, sofrendo maiores mudanças no século XX, acompanhando o cenário sócio - econômico e político do país, que vai se desenvolvendo pelos modos de produção. Em cada modo de produção sempre, com uma característica distinta, como grupo de trabalhadores necessários para oferecer serviços no processo da saúde-doença em todos os espaços envolvidos (NÁJERA, 1990).

Para conhecer a evolução da Enfermagem, deve-se compreender o processo saúdedoença, caracterizado e destacado nos aspectos de saúde e educação, determinantes para explicar a situação específica da profissão, o marco de sua formação, sua prática, sua produtividade técnico-científica e sua capacidade de formar grupos.

Becerril et al., (2004) referem que, no contexto sócio - econômico e político, a enfermagem é produto de diversos fatores que tem influenciado na sua origem e desenvolvimento, três heranças recebidas por tradição: religiosa, feminina e militar.

A herança religiosa: está relacionada ao nascimento do cristianismo. É um trabalho realizado pela igreja nascente (diáconos e religiosas) e associado ao conceito de caridade cristã. No México, o exercício das atividades de enfermagem, por três séculos, foi responsabilidade de religiosas, vistas como a doação do serviço do cuidador ao cuidado. A enfermagem se impregnou de valores e rituais. Seu cuidado é entendido como um serviço ao próximo, uma vocação pessoal, mística e de manifesto público da caridade cristã aos cidadãos e/ou pacientes, concebido como uma pessoa feita à imagem e semelhança de Deus.

A herança feminina. A Enfermagem é considerada como uma profissão feminina conforme referem Frank; Elizondo (1987), ou seja, ocupações relacionadas a mulher, não só para atuar como trabalhadora, mas também, uma expressão da riqueza de seu gênero: mãe, esposa, filha e irmã. México (1999a) chama a atenção a esta designação, pois 95,8 \% do total de pessoal de enfermagem, no México, são mulheres, o que sugere a necessidade de uma 
conscientização e esclarecimento atual sobre a profissão de enfermagem e, assim, o crescimento de seu próprio campo de ação.

A herança militar. Teve efeito na introjeção de valores que promoveram uma forte hierarquização entre o pessoal, com firmação nos valores herdados da influência militar e especialmente do conceito de disciplina que implica cumprir ordens sem discussão, com imposição, por meio da vigilância, buscando governar, controlar e canalizar as potencialidades dos indivíduos, para alcançar a produtividade no cuidado da saúde. Becerril et al., (2004) consideram que os aspectos econômicos e políticos caracterizaram o século XX até o início do século XXI e teve um caráter decisivo tanto na formação quanto no exercício profissional de enfermagem. As políticas educativas e de saúde têm representado as diretrizes do processo educativo, assim como, da inserção no mercado de trabalho. Assim, durante os primeiros 80 anos do século $\mathrm{XX}$, foi privilegiada a formação para os atendimentos curativos, individuais e com modelo clínico. Entretanto, é importante entender que o estado de saúde não depende unicamente dos fatores biológicos que afetam a cada indivíduo, de maneira mais ampla, é o produto de um processo sujeito às determinantes dadas pela relação do homem com a natureza. Isto não significa que o processo saúde-doença não seja um fenômeno biológico, senão também, um processo social e histórico.

\subsubsection{A prática social da enfermagem.}

Martínez et al., (1998), referem que, em relação à prática, são observados três áreas de atuação claramente diferenciadas: parteira, sanitarista e enfermeira hospitalar.

A parteira. Há existência de documentos com registros de ações que formam parte da cultura autóctone relatando algumas funções desenvolvidas pela mulher no que se refere ao atendimento da saúde da população, de maneira especial na participação e atendimento dos partos. Flores (1994) refere que os partos nas cidades de interior eram atendidos por mulheres, reconhecidas pela população como parteiras, $20 \%$ eram atendidos por médicos e $2 \%$ no meio 
rural, cenário que acompanhou as grandes transformações no atendimento de médico desde 1920 até os dias de hoje.

Depois da Revolução Mexicana (1910), se construíram várias maternidades e o atendimento era oferecido por integrantes da população, que contavam com o reconhecimento social como parteiras profissionais. Além do atendimento no momento do parto, eram encarregadas do controle da gravidez e do atendimento do recém nascido. Na década de 40 o IMSS e no ISSSTE iniciaram a substituição do atendimento das parteiras, pelo atendimento médico. Dessa forma, foi requerido como situação ideal, no momento do parto, um atendimento dentro de uma maternidade e por um parteiro especializando (RABAGO, 1954).

$\mathrm{O}$ auge das atividades da enfermeira parteira foi no século $\mathrm{XX}$, particularmente no período compreendido entre 1933 a 1943. Najera (1992) refere que a característica mais relevante desta prática esteve relacionada à acessibilidade sócio - econômica e cultural dos usuários. $\mathrm{O}$ atendimento materno-infantil era realizado no contexto familiar e domiciliar por um custo aceitável, oferecendo-se o atendimento de forma humana e de caráter integral por mulheres parteiras, e por outras mulheres. A prática da parteira foi perdendo campo de ação, à medida que surgiam os médicos especialistas e o atendimento do parto foi se institucionalizando.

A enfermeira sanitarista. É outra vertente no desenvolvimento da prática de enfermagem no México. Representado pela enfermeira em saúde pública ou sanitarista. O grupo de enfermeiras sanitaristas, desenvolvimento de uma obra importante a partir da revolução de 1910, representando uma das páginas mais importantes da história da saúde no México.

Martinez et al., (1998) referem que a enfermagem sanitária, iniciou em 1921, tardiamente em relação ao início do atendimento hospitalar e das parteiras. Seu papel na sociedade era, entre outros, controlar as epidemias e prevenir doenças mediante vacinação. 
Cumpria papel de visitadoras, saindo à comunidade para visitar as famílias, para fazer atividades de prevenção e promoção da saúde à comunidade, práticas e cuidados de higiêne para as crianças e mulheres grávidas. Em 1921, o Departamento de Salubridade iniciou campanhas de controle de doenças com atividades de com 19 sanitaristas e, em 1982, aumento a 17.764 (MEXICO, 1982). O aumento de trabalhadores e a multiplicidade das atividades desenvolvidas tornaram necessária a realização de diversas reformas administrativas. Foi criada a direção de Enfermeiras em todas as áreas e locais onde se contava com serviço da enfermagem. Assim, foram estabelecendo-se as direções estaduais e a sessão de enfermagem na Direção Geral de Serviços Coordenados. No IMSS e no ISSSTE estabeleceram-se departamentos responsáveis por medicina preventiva para beneficio dos usuários com atenção de enfermagem.

Em meados da década de 60, se inicia o declínio da "enfermeira sanitarista", passando a ser destituída dos postos e, substituídas pelos médicos.

A enfermeira hospitalar. Surge no início do século XX. Com o avanço científico, tecnológico e o desenvolvimento da medicina moderna foi requerida a presença da enfermagem. O desempenho da enfermagem dentro do hospital iniciou com grandes deficiências nas condições de trabalho, pouca valorização, exploração marcada, e condições insalubres de trabalho. Eram contratadas em período integral, sem direito a dias de descanso, ou seja, em regime de internato. Em 1933, no Hospital Geral do México foram estabelecidas algumas condições de trabalho para a melhoria do trabalho hospitalar. A "Senhorita Gómez Sigler", diretora de enfermagem conseguiu a supressão do regime de internato e a redução da jornada de trabalho (12 horas diárias), além de triplicar o número de profissionais. No ano 1939, foi estabelecida a jornada diária de oito horas e o direito a um descanso semanal. Não existia, de forma oficial, a preparação de enfermeiras especialistas, razão pela quais as 
diversas funções desempenhadas lhe outorgavam certo reconhecimento de especialidade prática. (MARTINEZ et al., 1998).

Na década de 40, surgem os grandes hospitais especializados: Nutrição, Cardiologia, Infantil, entre outros. Com o crescimento da força produtiva do setor industrial nasce a seguro social para os trabalhadores: o IMSS, o ISSSTE, a PEMEX, a SEDENA, a SEMARNA, formalizando a institucionalização profissional das enfermeiras.

O ano 1954 marca uma nova época no desenvolvimento da Enfermagem, tanto hospitalar quanto sanitarista. Na cidade Zimapán, foi realizado um seminário, organizado pela Secretaria de Saúde, a Organização Pan-americana da Saúde e a Universidade Nacional Autônoma do México. O objetivo foi realizar uma revisão dos problemas existentes no desempenho da profissão e propor soluções com importantes repercussões. Assim, foi conhecido que, dentro dos hospitais, mais da metade dos postos de trabalho estavam ocupados por enfermeiros, que a maior parte dos serviços hospitalares estavam relacionados, com a enfermagem, a enfermeira era o profissional que passava mais tempo do lado do doente, não era contemplado no número de enfermeiros necessários nos hospitais. Por exemplo, o Hospital Geral do México, que comporta 1800 leitos, contava com 500 enfermeiros, dos quais unicamente 50 eram profissionais (LEIJA, 1954). A autora relata quatro fatores que desestimulavam os jovens a seguir esta profissão: a falta de reconhecimento do nível profissional da enfermagem, a carência de uma compensação adequada para suas extenuantes jornadas, a ausência de estímulos profissionais, a situação deficiente e antiquada dos hospitais e dos centros de trabalho de enfermagem. Da falta de diferenciação, legal e profissional, entre a enfermeira titulada e a auxiliar ou empírica. As falhas das organizações hospitalares, sem dúvida, se refletiam na qualidade do trabalho da enfermeira.

Quinze anos depois do seminário de Zimapán, a enfermagem hospitalar cresceu em número, melhorou sua preparação e, como grupo, melhorou sua organização. Em 1958, foi 
criada a Direção Geral para Enfermagem no país, organismo que permitiu que as enfermeiras tivessem certo nível de decisão em suas competências.

A profissão de enfermagem de hoje, pela sua prática cotidiana, dirige seu trabalho ao individuo, à família, à comunidade, aos trabalhadores, aos escolares e aos idosos, entre outros, e em diferentes cenários, seja esse social, político, assistencial e/ou gerencial (CASASA, 2001). Nessa mudança na prática de enfermagem, as transformações no panorama sóciopolítico e econômico do México têm influído notavelmente, além de fatores como:

a) O avanço da saúde pública e sua contribuição ao desenvolvimento da saúde gerando novos modelos interdisciplinares de intervenção do fenômeno saúde-doença entre os grupos;

b) A nova concepção da saúde, que é vista como um fenômeno multi-fatorial relacionado com aspectos biológicos, culturais e sociais. O que implica para a prática de enfermagem visualizar o cuidado à saúde em diferentes âmbitos e não só ao cuidado dos pacientes;

c) Os desenvolvimentos teórico, conceitual e prático, da profissão de enfermagem, têm mostrado a capacidade necessária para entrar em cenários diversos, onde a saúde e a doença se expressam como fenômenos sociais humanos, vinculados com os diversos modelos de desenvolvimento social;

d) As políticas internacionais e nacionais em matéria de saúde, particularmente a estratégia de Atendimento Primário em Saúde, permitiu à comunidade valorizar e reconhecer práticas em enfermagem como modelos de atendimento em saúde (crianças, idosos, maternoinfantil), a conformação de grupos de risco e sua participação nos programas de saúde que contribuem na ampliação da cobertura.

Pelo exposto e, baseada na experiência acumulada na profissão de enfermagem, é possível dizer que, hoje se reconhece a necessidade de um papel ampliado da prática da enfermagem em diversos âmbitos, entre os que se destacam: a saúde escolar, a saúde no 
trabalho, a mobilização das comunidades na busca de melhores condições de saúde, a saúde ambiental, entre outros, onde a liderança está presente.

Nos últimos vinte anos se iniciou um forte movimento caracterizado pelo seu interesse nas ações de profissionalização da enfermagem, a partir de um controle sobre o sistema de educação, o recrutamento e capacitação do pessoal nas diferentes instituições do setor saúde para enfrentar o déficit de enfermeiras e a qualidade de sua prática.

Quanto ao número de enfermeiras, o Sistema de Administração de Recursos Humanos em Enfermagem (SIARHE) (MÉXICO, 1999a) mostra que em 1999, nos serviços de saúde, trabalhavam 152.157 pessoas de enfermagem, dos quais $61,5 \%$ correspondiam ao pessoal profissional. O maior número de enfermeiras $52 \%$ se encontra trabalhando no IMSS, $28,3 \%$ na Secretaria de Saúde, 9,8\% no ISSSTE e o restante $(9,9 \%)$ distribuídas entre outras instituições, públicas e privadas. Segundo dados da Entidade Federativa, no Distrito Federal concentram-se $22,5 \%$ do pessoal de enfermagem, 6,5\% no Estado do México, 5,7\% em Veracruz, 5,6\% em Nuevo León e 5\% em Jalisco.

Por outro lado, segundo o SIARHE, a maior porcentagem de enfermeiras $(55,2 \%)$ trabalha em instituições hospitalares de nível secundário de atendimento, 23\% se encontra em instituições hospitalares de nível terciário e 21,8\% no nível primário de atendimento.

A sociedade tem permitido redefinir a prática de enfermagem a partir do reconhecimento e do valor social que ela dá a tal atividade profissional. O papel da enfermeira está mudando e sendo influenciado pelo desenvolvimento científico e pela regulamentação do exercício profissional. Alem disso, existem outros elementos que tem influenciado, a partir da sociedade, na mudança do papel da enfermagem atual, como o consentimento informado, os direitos do paciente, a padronização da prática, o desenvolvimento da investigação, da docência e dos projetos de avaliação da qualidade, entre outros. Soma-se a estas mudanças uma transformação qualitativa da prática da enfermagem que diz respeito a maior habilidade 
para a valorização, planejamento, execução e avaliação das intervenções, maior autonomia profissional e melhores níveis de formação, mas ainda é insuficiente o número de enfermeiras para cobrir as demandas da população.

A Secretaria de Saúde do México caracteriza as tendências da prática de enfermagem como um serviço científico-social próprio, centralizado no conceito integral do homem e em preposições de caráter científico derivadas da proposta teórico-científica dos cuidados e de uma identidade profissional e disciplinar. O desenvolvimento da profissão, nas instituições de saúde, a partir da oferta de estudos de pós-graduação de nível de especialidade, mestrado e doutorado possibilitam o pensamento de que a Enfermagem mexicana está avançando para cumprir com o objetivo principal da profissão: o cuidado da vida e integridade do homem na saúde e na doença.

\section{Enfermagem no hospital geral.}

Estes profissionais são os responsáveis pelo cuidado “de enfermagem”, intra ou extrahopitalar, e na parte administrativa, está organizado por um Diretor do Departamento de Enfermagem cuja dependência hierárquica, na maioria dos casos, é da direção ou subdireção médica, conforme o caso. A supervisão dos profissionais de enfermagem está a cargo da direção da enfermagem.

A equipe de trabalho está integrada em $60 \%$ por enfermeiros e $40 \%$ por auxiliares de enfermagem, distribuídos em quatro períodos de trabalho: a) 35\% diurno, b) 25\% vespertino e c) noturno, o qual está subdividido em dois períodos (A e B) com $20 \%$ e $20 \%$ cada noite.

As enfermeiras estão distribuídas nas áreas de hospitalização, consulta externa, cuidados intensivos, central material, sala de cirurgia, recuperação, nas quatro especialidades básicas (ginecologia-obstetrícia, medicina interna, cirurgia e pediatria). Para o oferecimento do atendimento de enfermagem, o hospital conta com normas, manuais e regulamentos que 
servem de guia, tanto para a realização do cuidado, quanto para garantir os procedimentos administrativos e médicos.

Com a intenção de especificar o nível de desempenho e funções do pessoal de enfermagem, os hospitais contam com catálogos de postos e diagramas profissionais, estes documentos não oferecem uma clara diferenciação, entre as responsabilidades que devem ser assumidas pelo profissional e o não profissional. As atribuições têm respondido às necessidades de cobrir a falta de enfermeiras ou a compromissos trabalhistas, não sendo considerado prioritário o atendimento qualificado de enfermagem. Isto torna evidente a necessidade de definir os perfis que delimitam as funções, ações e responsabilidades de integrante da equipe e que motivem o desenvolvimento do potencial da equipe de enfermagem.

Para cumprir com este propósito, diferenciar o trabalho profissional do não-profissional, atualmente se conta com cinco perfis, dados pela Coordenação Interinstitucional de Enfermagem, (MÉXICO, 2002). Seguindo uma ordem de maior ou menor preparação acadêmica, cada nível contém uma descrição geral, requisitos de formação acadêmica e aptidões que definem sua participação no atendimento dos indivíduos, sãos ou doentes, em um hospital. As funções desempenhadas são classificadas em: assistenciais que compreendem ações relacionadas com o atendimento direto aos usuários dos serviços de enfermagem; administrativas que correspondem ao papel de gestor de recursos necessários e complementares para a conquista dos objetivos dos usuários, da organização e dos prestadores dos serviços; docentes dedicadas principalmente às atividades de educação para a saúde e para as relacionadas com a educação continuada ou para a formação dos novos recursos; e de investigação que descreve as habilidades para aplicar a metodologia científica da investigação, dos conhecimentos práticos que delas se derivam, assim como, das ações que permitem contribuir com a definição ou desenvolvimento do exercício profissional. 
De acordo com o grau de responsabilidade, da tomada de decisões ou autonomia se denominam como: a) Dependentes: atividades realizadas geralmente por não-profissionais ou em formação e se realizam sob supervisão do profissional de enfermagem ou por prescrição de outro profissional da área da saúde; b) Interdependentes: atividades realizadas por profissionais de enfermagem e em coordenação com outros profissionais da área da saúde; e c) Independentes: atividades realizadas pelos enfermeiros sob seu próprio juízo profissional e são assumidas exclusivamente por profissionais. As atividades são ações específicas que se realizam para operacionalizar uma intervenção, portanto, cada atividade de enfermagem se converte em uma ação concreta, necessária para levar à prática uma intervenção, por meio de uma série de atividades.

Com relação à operacionalização, o pessoal é selecionado e classificado segundo seu perfil, são conduzidos ao posto, colocados conforme as necessidades do hospital, avaliados cada mês em relação ao seu desempenho, pontualidade, assistência e, com base em resultados, são estimulados economicamente, contribuindo em sua avaliação a qualificação. Assim também, participa de processos seletivos para cargos de direção, supervisão de enfermagem e de programas dirigidos ao desenvolvimento dos membros da equipe por meio de programas de educação continuada (MEXICO, 2001b).

É necessário legitimar o exercício profissional da Enfermagem, entendendo que seu potencial de desenvolvimento enfatiza a possibilidade de realizar funções de assistência, gerência, docência e investigação, nos diferentes papéis como provedor, coordenador e auditor das funções genéricas e nos cenários que incluem os três níveis de atendimento à saúde, com um grau de autonomia congruente a sua formação ética e profissional (MEXICO, 1999a).

Neste sentido existe a necessidade de institucionalizar as tarefas da enfermeira profissional e a sua liderança no atendimento aos pacientes, de maneira especial, as funções 
potenciais as quais se encontra em condições de realizar, de maneira a apoiar a estratégia de atenção primária. Para tanto, é importante que, o profissional de enfermagem, reconheça os problemas de saúde, as reformas nos sistemas de serviço e o avanço das ciências biomédicas, que exigem uma mudança de paradigma na prática da enfermagem profissional. Esta breve descrição do panorama torna evidente a necessidade de uma re-concepção da prática, distinguir o tipo de relação com as competências da enfermeira e nível de participação, responsabilidade, autonomia e interação com outros profissionais ou técnicos da saúde, a partir das quais se possam caracterizar as funções de um enfermeiro profissional.

\subsection{A LIDERANÇA EM ENFERMAGEM}

A Enfermagem tem experimentado a necessidade de incrementar sua participação na gestão das organizações de saúde, ultrapassando seu papel meramente operacional que, em forma atávica, lhe foi socialmente designado. Para poder escalar, de forma definitiva, este degrau na hierarquia organizacional, percebe-se a importância de aprofundar no estudo da teoria e da prática da liderança, em sua contextualização nas organizações de saúde mexicanas e em sua relação com seu comportamento em um processo dialético sujeito-objeto, por ser, a liderança, um fenômeno subjetivo. No México, se observa uma liderança complexa, razão pela qual, é de nosso interesse identificar a percepção de liderança entre as enfermeiras que ocupam cargos diretivos nas organizações de saúde.

O propósito de uma organização é permitir que seres humanos comuns façam coisas pouco comuns. Drucker (2000) refere que nem todas as organizações conseguem alcançar este propósito, pois depende, em certa forma, da existência de pessoas que desempenham liderança nos postos de direção, desde que estas propiciem a motivação e o trabalho em equipe e membros, conhecidos como seguidores. Como conseqüência se espera maior eficiência e eficácia. 
Moreno (2003) refere que o registro mais antigo que se conhece de um sistema de "administração" é o Código de Hammurabi, compilado aproximadamente 2000 anos aC, na Bíblia e Papiros egípcios que datam do ano de 1300 aC. Naquela época, sobressaia a organização e administração da burocracia pública no antigo Egito. Os personagens que administravam eram considerados líderes. Referências semelhantes são encontradas na Mesopotâmia, Assíria, Grécia, Peru, México, Equador, Bolívia e Chile (GEORGE, 1987).

À medida que mudam as condições e as pessoas, mudam os estilos de liderança. Atualmente as pessoas buscam novos tipos de líderes que ajudem a alcançar as metas. Historicamente se menciona que existiram cinco períodos da liderança e atualmente estamos em um período de transição direcionado para o sexto período da liderança de conquista, comercial, organizacional, liderança de inovação e de informação como os descreve Gaytan (2005):

-Período da liderança de conquista. Durante este período a principal ameaça era a conquista. As pessoas buscavam um chefe onipotente; mandatário despótico e dominante que prometesse a elas segurança em troca de sua lealdade e de seus impostos.

-Período da liderança comercial. Ao princípio da idade industrial, a segurança já não era a função principal de liderança e, as pessoas, buscavam líderes que os ajudassem na melhora do nível de vida.

-Período da liderança de organização. Elevaram-se os padrões de vida e tornaram-se fáceis de alcançar. As pessoas iniciaram a busca de um lugar ao qual "pertencer". A medida da liderança se converteu na capacidade de organizar-se.

-Período da liderança e inovação. À medida que a inovação se incrementava, com freqüência, os produtos e métodos se tornam obsoletos antes de sair da lista de planejamento. Os líderes do momento eram extremamente inovadores e podiam administrar os problemas da crescente evolução e da obsolescência. 
-Período da liderança da informação. Os três últimos períodos se desenvolveram extremamente rápido (iniciando na década de 20). Fez-se evidente que nenhuma empresa pode sobreviver sem líderes que entendam ou saibam como se maneja a informação. O líder moderno, da informação, é aquele que melhor processa, interpreta e utiliza de maneira criativa a informação.

Liderança no "Novo período" (século XXI). Continuou o estilo de liderança situacional com ênfase na honestidade. As habilidades especiais e necessárias para os líderes do futuro não podem ser previstas. Somente podemos fazer conjeturas prováveis. Os líderes necessitam saber como utilizar as novas tecnologias e como pensar para poder analisar e sintetizar eficazmente a informação que estão recebendo. Apesar da nova tecnologia, sua dedicação deve seguir enfocada no indivíduo. O líder deve ser ciente de que dirige pessoas e não objetos, números ou projetos, têm que desenvolver sua capacidade de escuta com a finalidade de descrever o que as pessoas desejam, e deverá desenvolver sua capacidade de projetar, a longo e curto prazo, segurança, confiança, energia e empenho, assim, conservando uma margem de competência que permita garantir sua liderança frente aos seguidores conscientes, preparados e informados (GAYTAN, 2005).

\subsubsection{Conceito de liderança}

São múltiplas as investigações que se realizaram na última década e muitos os pesquisadores que se interessam a oferecer resultados de estudos do fenômeno: liderança. De Gortari (2000) refere que a palavra líder vem do termo inglês leader, que significa guia. Conforme o Dicionário da Real Academia Espanhola, líder é a "pessoa que por sua conduta pretende modificar o comportamento e disposição de outras pessoas".

Hersey; Blanchard; Johnson (2001) referem que o estudo do fenômeno de liderança considera três atores: o líder, os seguidores e o ambiente organizacional. Moreno (2003) considera que o líder trabalha para ser aceito pelo seu carisma e pelo seu serviço em uma 
equipe que requer ajuda e orientação para cumprir com as metas que foram negociadas e prefixadas. O líder representa o apoio ou guia da equipe, e estimula seus seguidores para que desenvolvam suas inquietudes, iniciativas e criatividade. Fomenta a responsabilidade, o espírito de equipe, o desenvolvimento pessoal e, especialmente, deve ser assertivo na criação de um espírito de "pertença" que une os colaboradores na decisão das medidas a serem tomadas. O ambiente é determinante tanto para o líder quanto para os seguidores. Hersey e Blanchard (1988) definem liderança como “o processo de influência sobre as atividades do individuo ou grupo de indivíduos para a consecução de um objetivo comum em uma determinada situação". Os autores ressaltam que não se pode pensar que a relação líder/liderado, sempre, se trata de uma relação hierárquica do tipo superior/subordinado. Sempre que uma pessoa procura influenciar o comportamento de outra, a primeira é o líder potencial e a segunda o liderado potencial, não importando se esta última é o diretivo, subordinado, colega, amigo ou parente (HERSEY; BLANCHARD, 1988).

Chiavenato (2005) acrescenta que a liderança é “o processo de persuasão e exemplo pelo qual um indivíduo, ou equipe de trabalho, induz a um grupo na busca de objetivos definidos pelo líder". Ademais, torna-se necessária em todos os tipos de organizações humanas, adquirindo grande importância nas funções do diretor, já que, esse necessita saber conduzir as pessoas.

Segundo os autores da Teoria das Relações Humanas, a liderança pode ser vista em três perspectivas (TANNENBAUM, 1970):

a. Liderança como fenômeno de influência interpessoal. Considera-se que "a liderança é a influência interpessoal exercida em uma situação, orientada à consecução de um ou de vários objetivos específicos mediante o processo de comunicação humana" 
b. Liderança como processo de redução da incerteza de um grupo. O grau de qualidades de liderança, demonstrada por um indivíduo, depende, não só, de suas próprias características, como também, das características da situação em que se encontra.

c. Liderança como relação funcional entre líder e subordinados. A liderança está em função de certas necessidades em determinadas situações, e representa a relação entre um indivíduo e um grupo de indivíduos. A relação entre líder e seguidor fundamenta em três generalizações: 1) A vida de cada pessoa pode ver-se como uma luta contínua por satisfazer necessidades, aliviar tensões e manter o equilíbrio; 2) Em nossa cultura, a maior parte das necessidades individuais são satisfeitas por meio das relações com outras pessoas e grupos sociais; e 3) Para qualquer pessoa, o processo de relação com outras pessoas é um processo ativo de satisfação de necessidades.

As pessoas não esperam encontrar uma relação capaz de proporcionar-lhe os meios para satisfazer uma necessidade que surja de maneira natural, estão em busca as relações adequadas para consegui-lo e utiliza as relações, já existentes, com o fim de satisfazer suas necessidades pessoais. Na relação funcional, o grupo percebe o líder como a pessoa capaz de controlar os meios para satisfazer suas necessidades. Por essa razão, para o grupo, segui-lo pode constituir em aumento da satisfação de suas necessidades ou de evitar sua diminuição de satisfação. Em conseqüência, o líder é um estrategista que orienta o rumo da organização, e ela está entendida como a inter-relação das pessoas.

d. A liderança como processo em função do líder, dos seguidores e das variáveis de situação. A liderança representa o processo de exercer influência sobre uma pessoa ou um grupo de pessoas que se esforçam por alcançar seu objetivo em situações determinadas. A liderança depende de três variáveis: a. O líder (1); b. Os seguidores (s); e c. da situação (v). Da qual se deriva a seguinte equação: $L=f(l, s, v)$. A liderança se apresenta em função das necessidades existentes em determinada situação, isto é, das características pessoais do líder, 
dos subordinados e da situação em que se encontram. É um enfoque situacional. O líder conjuga e adapta todas estas características. Portanto, não existe um único tipo de líder e exclusivo para cada situação (HERSEY; BLANCHARD, 1988).

Ao longo da história se viu que as pessoas que são líderes não precisam aplicar o mesmo estilo em todos os momentos e circunstâncias, ser líder não deve ter uma conotação permanente e vitalícia, ao usar a denominação: exercer a liderança. Uma pessoa pode ser líder em uma faceta determinada de sua vida, por exemplo, em sua vida profissional, porque tem um grupo de seguidores e não ser em outras facetas, como em sua vida familiar, ou pode exercer a liderança com autoridade em um grupo determinado e ser seguidor em outro grupo.

Senge (1990) refere que autoridade está representada pelo poder, mas dentro de uma organização, o poder está concentrado nos cargos diretivos e, por conseqüência na pessoa que ocupa o cargo. Neste ponto de vista, autoridade seria sinônimo de direção. A liderança requer de poder, e quando exercida, se converte em influência. Embora, todos os líderes tenham poder, nem sempre todas as pessoas com poder exercem a liderança.

A diferença entre os termos direção e liderança, mostra que nem sempre o líder que ocupa um cargo de direção, pode ser o líder que encontre-se entre os subordinados, o que pode originar uma liderança informal. Apesar disto, em toda organização com tendência burocrática, se busca que seja a pessoa que ocupa um posto de direção de enfermagem quem exerça a liderança, de forma que a estrutura formal e a informal da organização coincidam. Esta coincidência favorece a orientação dos membros de enfermagem da organização para um mesmo caminho e em uma mesma direção. Este é o conceito usado neste estudo pelo qual se considerou importante mencionar alguns enfoques e teorias de investigadores que nos oferecem sua experiência e corpo de conhecimentos. 


\subsubsection{Enfoques e teorias de liderança}

Ao longo de todos estes anos se construíram enfoques e grande número de teorias e modelos sobre a liderança. Moreno (2003) refere que os enfoques se concebem como um conjunto de visões e aproximações à explicação de um tema determinado, neste caso da liderança. Gaytan (2005) descreve os três enfoques mais estudados como:

a. O enfoque que agrupa as teorias das características

Este enfoque pretende encontrar as características sociais, físicas, intelectuais ou de personalidade que possuem os líderes e, que os distingue do resto da população. As características de um líder eram consideradas inatas à pessoa e, atualmente, se consideram como um conjunto de características que podem ser aprendidas.

\section{b. O enfoque que agrupa as Teorias das condutas.}

Este enfoque agrupa um conjunto de teorias que considera a liderança como a conseqüência de uma série de condutas do líder e não das características que esse possui. Isto permite o pensamento de que é possível treinar as pessoas para serem líderes.

c. O enfoque de teorias de contingência.

Com este enfoque permite olhar a liderança como um fenômeno dinâmico e transformador. Kast e Ronsenzweig (1994) consideram que o enfoque das teorias de contingência agrupa teorias dirigidas aos fatores situacionais. Não basta que o líder apresente características ou condutas determinadas, é necessário olhar para outros fatores, como, as características dos seguidores, as circunstâncias ambientais, entre outros. No presente estudo, pretende-se conhecer a liderança concebida com este enfoque descrito no modelo de Hersey e Blanchard (1988).

Chiavenato (2005) refere que da Teoria de contingência se derivam três estilos de liderança: transacional, visionário e situacional. É, a teoria situacional, a base do presente estudo. 
A teoria da liderança situacional concebe que não existe um único tipo de liderança que seja eficaz em todas as situações, e sim, que cada um dos tipos de liderança, definidos pelos autores (os definem em função de ser alta ou baixa a importância concedida à tarefa e à relação com os demais) é eficaz em uma situação determinada.

Cada líder tem um tipo de liderança determinado, porém, um bom líder deve saber utilizar os distintos tipos de liderança, e ainda deve saber utilizá-los em função do grau de maturidade em que se encontra a equipe. Quando a equipe mostra um baixo grau de maturidade, o líder assume a direção e a tomada de decisões referentes ao grupo. Com o aumento do grau de maturidade da equipe, surge a necessidade de que o líder exerça um tipo de liderança “menor”, já que o grupo se mostrará mais autônomo, assumindo suas decisões. O líder participa como membro do grupo, exercendo representatividade ao exterior do mesmo.

\subsubsection{A teoria de Liderança Situacional de Hersey e Blanchard}

A importância do diagnóstico da habilidade de um líder foi expressa por Schein (1982): “O administrador de êxito deve ser capaz de diagnosticar e avaliar o espírito de investigação. As habilidades dos seguidores do líder variam; não obstante, os administradores devem ter a sensibilidade e a habilidade de diagnosticá-las para poder perceber e apreciar as diferenças”. Em outras palavras, os gerentes devem ser capazes de identificar senais em um determinado ambiente, e com isso devem expressar habilidades para diagnosticar. A efetividade do líder dependerá da adoção de estilos de liderança adequados às demandas do ambiente.

Os líderes devem mostrar flexibilidade no trato pessoal, e habilidades para variar seu comportamento, em função das necessidades e motivos de seus seguidores. A atitude dos seguidores varia, os lideres ou diretivos devem tratá-los de forma diferente. Por essa razão, Hersey e Blanchard (1988) desenvolveram um modelo de liderança prático, com o objetivo de que pudesse ser aplicados por gerentes, vendedores, professores, no processo de tomada de 
decisões com o objetivo influenciar outras pessoas. O resultado é a liderança situacional que usa, como dados básicos, as percepções e observações dos gerentes, supervisores ou pais de família no cotidiano de seu ambiente.

O modelo de liderança situacional foi desenvolvido por Hersey e Blanchard (1988) no Centro de Estudos de Liderança, no final da década de 60, continuando, até 1982, em procura da melhora do modelo. Posteriormente, Blanchard e Zogarmi (1985) e colaboradores no Blanchard Training Development (BTD) modificaram o modelo original de liderança situacional e desenvolveram modelos de diagnóstico e materiais de treinamento como seminários.

\section{Liderança Situacional}

A liderança situacional se baseia na interação do comportamento do líder e do comportamento dos seguidores, com a finalidade de determinar qual é o estilo de liderança mais efetivo frente a um determinado grau de habilidade e disposição dos seguidores. Então, todas as variáveis situacionais, como o líder, seguidores, os associados, as organizações, as demandas trabalhistas e o tempo são importantes. Para Stanford (1950) apresenta que a ênfase na liderança situacional está no comportamento de um líder em relação ao comportamento dos seguidores "como o fator mais crucial em todo evento de liderança". Hersey e Blanchard (1988) referem que os seguidores são vitais em toda situação, não somente porque tornam legítima a ação do líder, mas porque, os seguidores constituem a maior fonte de poder que o líder pode ter.

O modelo de liderança situacional, de acordo com seus autores, não é uma teoria. A diferença entre uma teoria e um modelo, é que a primeira tenta explicar as causas dos acontecimentos e o modelo é um padrão para recriar ditos acontecimentos. O modelo de liderança situacional é um guia para alcançar o êxito do líder em sua tarefa de influir sobre seus seguidores, sem importar o papel ou hierarquia que ocupe na organização. É, portanto, 
útil para quem tente influir no comportamento dos demais, sejam eles, empregados, associados, amigos, parentes ou família. De acordo com o modelo de liderança situacional não há uma forma ótima para influir sobre as pessoas. O estilo de liderança, que uma pessoa utiliza para influenciar outro indivíduo ou grupo de indivíduos, depende do grau de maturidade (habilidade e disposição) das pessoas.

\section{As dimensões do comportamento do líder}

O modelo de liderança situacional contempla dois grandes temas: “o estilo do líder” e "a maturidade dos seguidores". O estilo do líder, por sua vez, está dividido em dois componentes: o comportamento orientado às tarefas e o comportamento orientado às relações humanas, e a maturidade dos seguidores pelos componentes: a habilidade para desempenhar uma tarefa específica e a disposição para realizá-la.

O estilo de liderança, orientado às tarefas ou às relações, é definido como o comportamento do líder percebido pelos seguidores. Hersey e Blanchard (1988) definem o comportamento à tarefa "como a tendência do líder a se referir aos deveres e responsabilidades de um indivíduo ou grupo de indivíduos. Isso é manifesto quando delega responsabilidade e diz o que deve, como deve, quando deve, onde deve e quem deve realizálo”. A orientação às relações interpessoais é definida como a tendência do líder para uma comunicação bidirecional. Essa é manifesta quando o líder escuta, facilita e apóia. A orientação às tarefas e a orientação às relações constituem as duas dimensões do modelo. Ambas representam as duas variáveis principais de um plano coordenado. O comportamento do líder, frente às tarefas, se encontra no eixo horizontal e, o comportamento às relações, está situado no eixo vertical, do plano coordenado.

Se utilizarmos uma escala dicotômica (alto e baixo), para qualificar o grau de comportamento de cada variável, se obtém quatro quadrantes que permitem identificar os quatro estilos básicos de liderança. (FIGURA 1). 


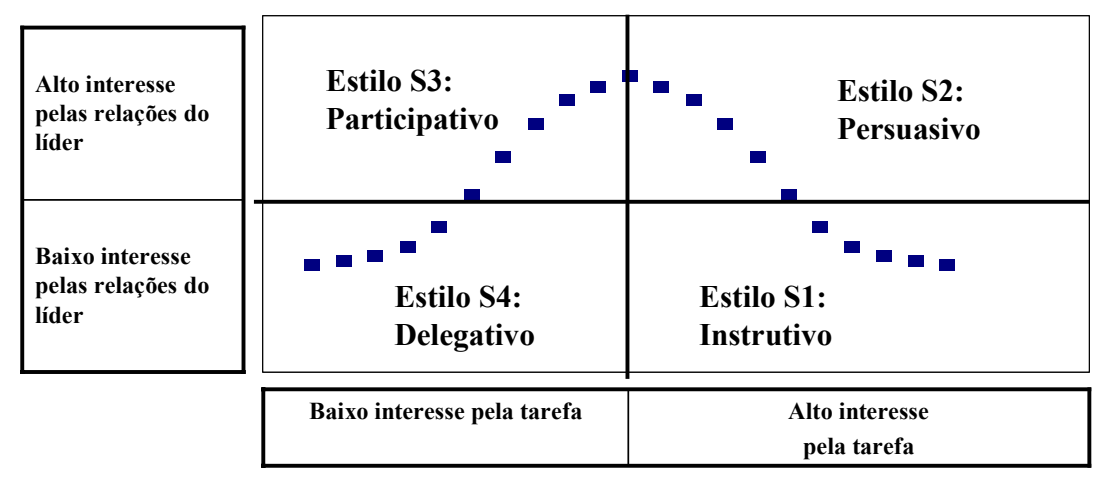

\begin{tabular}{|c|c|c|c|c|}
\cline { 2 - 5 } \multicolumn{1}{c|}{} & \multicolumn{1}{c|}{ Alto } & \multicolumn{2}{c|}{ Moderado } & Baixo \\
\cline { 2 - 6 } & \multicolumn{1}{c|}{ R4 } & \multicolumn{1}{c|}{ R3 } & \multicolumn{1}{c|}{ R2 } & R1 \\
\hline $\begin{array}{c}\text { Maturidade } \\
\text { dos } \\
\text { seguidores }\end{array}$ & $\begin{array}{l}\text { Alta habilidade } \\
\text { e alta } \\
\text { disposição }\end{array}$ & $\begin{array}{l}\text { Baixa } \\
\text { habilidade e alta } \\
\text { disposição }\end{array}$ & $\begin{array}{l}\text { Alta habilidade } \\
\text { e baixa } \\
\text { disposição }\end{array}$ & $\begin{array}{l}\text { Baixa } \\
\text { habilidade e } \\
\text { baixa } \\
\text { disposição }\end{array}$ \\
\hline Interativo & Próativo & \multicolumn{1}{c|}{ Reativo } & Inativo \\
\hline
\end{tabular}

Fuente: Hersey, P., Blanchard, K. H., Jonson, D. E. Management of organizacional behavior. 8a. Ed. Prentice Hall. New Jersey. 2001. P. 182.

Figura 1 - Relação entre os estilos de liderança e maturidade dos seguidores

\section{Os quatro estilos de liderança}

Estilo 1: Instrutivo (S1)- Estilo de liderança caracterizado por um alto comportamento direcionado às tarefas e baixo comportamento às relações.

Estilo 2: Persuasivo (S2)- Estilo de liderança caracterizado por alta orientação às tarefas e alta orientação às relações.

Estilo3: Participativo (S3)- Estilo de liderança caracterizado pela alta tendência às relações e baixa tendência às tarefas.

Estilo 4: Delegativo (4)- Estilo de liderança caracterizado por baixa tendência às tarefas e baixa orientação às relações.

\section{A situação}

A situação na qual o líder tenta exercer sua influência é um complexo de fatores que se afetam de maneira interativa. Entre os principais fatores encontram-se: o líder, os seguidores, os supervisores, as associações dominantes, a organização, a estrutura, as demandas do meio ambiente e as decisões. Estes fatores não operam isoladamente mas de forma interativa. O 
líder deve adotar um estilo de liderança que acompanhe a situação, por exemplo, o estilo S1 freqüentemente se relaciona com situações de crises. Em relação ao tipo de organização, na qual o líder exerce sua influência, por exemplo, ao se tratar de uma organização altamente burocrática, dado o grau de impessoalidade e mecanicismo que impera nesse tipo de organizações, o líder deverá responder com um estilo S1, ou seja, altamente orientado às tarefas e em menor grau às relações.

É importante ressaltar que o líder deve responder, as diferentes situações, com um tipo de estilo que melhor se ajuste, mas não lhe corresponde criar a situação, ou seja, deve responder com um estilo S1 ante uma situação de crise, mas não deve criar a crise. Se o líder trata a uma organização como se estivesse em crise, pode tornar real a crise. Se ele trata aos seguidores como se fossem crianças, é provável que eles se comportem como crianças. Este é um dos mais importantes princípios no campo das ciências do comportamento, denominada por Merton (1996) como a "profecia autocumprida".

O líder deve elaborar suposições positivas, referentes ao potencial dos seguidores, sem perder a perspectiva para o diagnóstico da realidade e da situação em que se encontra envolvido. O pensamento positivo supõe que não há situação não-manipulável e sempre haverá um estilo de liderança apropriado para obter o melhor resultado.

\section{Os seguidores}

O líder deve ser consciente de que, a relação entre o líder e os seguidores, é a variável crucial em toda situação de liderança. Se os seguidores decidem não seguir o líder, o pensamento e as demandas do supervisor ou a hierarquia passam a ter pouca importância. Não há líder sem que ninguém que os siga.

Para maximizar a relação líder-seguidor, primeiramente o líder deve estabelecer os resultados das tarefas específicas que os seguidores devem alcançar como indivíduos e como grupo. Sem a determinação clara dos resultados como objetivos, metas, padrões, e outro, o 
líder não tem base para examinar a maturidade (habilidade e disposição ou intencionalidade) dos seguidores. As tarefas, seus objetivos e metas intermediárias são o meio de contraste para que o líder decifre o comportamento dos seguidores e o estilo de liderança com melhores probabilidades de êxito.

\section{Maturidade dos seguidores}

A maturidade dos seguidores, em uma situação de liderança, se define como o grau de habilidade e disposição ou intencionalidade que os seguidores demonstrem no alcance de uma tarefa específica, dependendo da tarefa e da forma em que lhe solicita que a façam.

A maturidade não é uma característica pessoal, não é uma característica para avaliar personalidade, valores, idade, entre outros. A maturidade é a forma como uma pessoa realiza uma tarefa particular. Este conceito de maturidade tem lugar em determinadas situações não é uma forma permanente de ser. Todas as pessoas têm diferentes graus combinados de habilidade e disposição segundo as circunstâncias e tipo de tarefa que deva realizar. Ninguém tem um padrão constante de maturidade para realizar todo tipo de atividade, por exemplo, um vendedor pode mostrar alto grau de maturidade para garantir uma nova venda, mas no referente à elaboração dos papéis necessários para fechar a venda, pode não ser tão maduro. $\mathrm{O}$ líder deverá adotar um estilo apropriado em cada tarefa: durante o processo de venda, deixar o vendedor sozinho e quanto à elaboração dos documentos, supervisá-lo mais diretamente até que o vendedor demonstre um alto grau de maturidade nesta tarefa também.

\section{Componentes da maturidade dos seguidores}

Os dois maiores componentes da maturidade são a habilidade e a disposição. O diagnóstico de habilidade e disposição dos seguidores se faz com base em uma tarefa específica, considerando seus indicadores. 


\section{A habilidade}

É o conhecimento, a experiência e a destreza que um indivíduo ou grupo de indivíduos têm em uma tarefa ou atividade particular.

Os principais indicadores da habilidade são: o conhecimento é mostrado mediante o entendimento de uma tarefa e a experiência, que diz respeito a destreza é demonstrada mediante a eficiência com que se executa uma tarefa e a experiência é demonstrada mediante a segurança com que se desenvolve a tarefa.

\section{A disposição}

Disposição é o grau de intencionalidade que um indivíduo ou um grupo tem de desenvolver uma tarefa e alcançar um determinado objetivo. Os principais indicadores da disposição dos seguidores são: a confiança demonstrada mediante a segurança com que se faz uma tarefa; o compromisso, que se demonstra com o cumprimento dos deveres e a motivação demonstrada pele entusiasmo em se ao desenvolver uma tarefa.

A disposição ou intencionalidade se mede em uma escala baixa e alta. Uma baixa disposição não significa necessariamente, que os seguidores em uma situação se comportem indispostos ou não intencionais. Pode ocorrer que a pessoa nunca antes tenha desempenhado uma determinada tarefa e, portanto, pode-se mostrar insegura e assustada. Em geral quando não se sente segurança, o termo indisposição pode ser mais apropriado quando por alguma razão o indivíduo falha ou perde seu compromisso e motivação.

Não obstante, os conceitos de habilidade e disposição se constituem em um sistema de influência interativa. Isto significa que uma mudança significativa da habilidade implica uma mudança significativa na disposição. O nível de conhecimento, de experiência, e de destreza freqüentemente afeta o grau de confiança, de compromisso e de motivação. Os graus combinados de habilidade e disposição que as pessoas têm em uma tarefa se reapresentam em quatro níveis de maturidade (Quadro 1). 
Quadro 1- Graus de maturidade e situação de seus componentes

\begin{tabular}{|l|l|l|}
\hline Graus de maturidade & Habilidade & $\begin{array}{l}\text { Disposição o } \\
\text { intencionalidade }\end{array}$ \\
\hline Inativo R1 & Não hábil & Indisposto \\
Reativo R2 & Não hábil & Disposto \\
Pró ativo R3 & Hábil & Indisposto \\
Interativo R4 & Hábil & Disposto \\
\hline
\end{tabular}

Campbell (1995), refere Hersey; Blanchard; Johnson (2001) do Centro de Estudos de Liderança, expandiu o nível da maturidade dos seguidores para incluir os indicadores dos quatro graus de maturidade. Cada situação de maturidade reapresenta uma combinação diferente de habilidade e disposição ou de confiança dos seguidores. No Quadro 1, é possível observar os indicadores de uma pessoa tipo R1 em uma tarefa específica ou seja: desempenho inaceitável e atitude insegura.

Dada a importância da avaliação do grau de disposição e habilidade de uma pessoa Campbel (1995) refinou ainda mais as características que deveria ter o comportamento R1, $\mathrm{R} 2, \mathrm{R} 3$ e R4.

Para Inativos R1, não hábil e indisposto: defensivo, contestatório ou queixoso; finalização tardia das tarefas; responde somente a uma solicitação muito específica; intensa frustração; não desempenha a tarefa em um grau aceitável; é intimidado pela tarefa; é confuso em sua orientação; desprovido de habilidade e intenção; não finaliza as tarefas; pergunta reiteradamente sobre a tarefa; evita a tarefa ou a passa a outro; atitude defensiva ou incômoda; sofre bloqueios por stress; conflitua-se no trabalho; conformista e apático; desinteressado em processo; linguagem pessoal incômoda: depressão, ombros caídos, encurvado; comportamento confuso e perturbado; não participa em tomada de decisões; temor a falhar;

Os seguintes pontos apresentam os indicadores de maturidade para Reativos R2 não hábil, mas disposto (intencionado) ou confidente: Fala com rapidez e intensidade; fala com clarezas; afirma com a cabeça, faz "Sim, eu sei”, como um autômato; escuta cuidadosamente; responde às perguntas em forma superficial; aceita as tarefas; atua com rapidez; ansioso ou 
excitado, apreensivo intimidado; interessado em seu beneficio pessoal; demonstra habilidade moderada; receptivo às sugestões; atento a tomada de decisões; entusiasta e expositor; inexperto nas novas tarefas; preocupado mais pelos resultados que pelos passos intermediários; evita os conflitos;

Para Pró ativos R3: Os indicadores de comportamento hábil, mas indisposto (não intencionado): duvidoso ou incapaz; abrumado ou sobrecarregado; busca reforço; entende o desempenho como uma forma de castigo; demonstra conhecimento e habilidade; mostra-se impaciente por terminar ou por dar o seguinte passo; assustado, abrumado, confuso, intimidado; renitente a trabalhar sozinho; solicita freqüente realimentação; questiona sua própria habilidade; enfoca-se em problemas potenciais; falta da auto-estima; compromete emocionalmente como líder; dificuldades em equipe;

Para os Interativos R4 hábil e disposto (intencionado): mantém ao chefe bem informado sobre o progresso das tarefas; faz uso eficiente dos recursos em seu desempenho; é responsável e orientado aos resultados; inteligente: compartilha livremente informação sobre as operações da tarefa; tem disposição para ajudar aos demais a tomar decisões; compartilha idéias criativas; executa tarefas; termina a tempo e às vezes antes; pode trabalhar com autonomia e segurança; orientado aos resultados; compartilha as boas e as mas notícias; decide corretamente em função da tarefa; tem alto padrão de desempenho; está dotado de maturidade; cumpre totalmente seus deveres; supera situações estressantes; nunca transgride uma regra ou instrução; supre deficiências alheias.

\section{Relação entre os estilos de liderança e a maturidade dos seguidores}

Na medida em que os seguidores se movem de um grau baixo a um grau alto de maturidade, a combinação apropriada de estilos de liderança entre orientação à tarefa e a relação também muda. A curva desenhada sobre os quatro estilos de liderança na Figura 1 reapresenta uma alta probabilidade de combinação entre o comportamento do líder e o 
comportamento dos seguidores. Para a utilização do modelo se identifica um ponto sobre a linha que mostra o comportamento dos seguidores em uma determinada tarefa. Logo se traça uma linha vertical desde esse ponto até encontrar a curva de estilos de liderança. Este ponto indica o comportamento do líder mais apropriado entre sua orientação às tarefas e sua orientação às relações, nesta situação específica. Note-se que a curva (figura 1) não vai com direção ao angulo (esquina) inferior tanto do quadrante esquerdo como do quadrante direito. A curva se porta como uma "assíntota" à esquerda e a direita.

Para selecionar a combinação entre o comportamento direcionado às tarefas e às relações com alta probabilidade de êxito não tem que ser exato. Dever-se-á buscar o estilo de liderança mais próximo ao grau de maturidade, tendo em vista que quanto maior a distancia entre o grau de maturidade e o estilo de liderança, menor será a probabilidade de êxito do líder de influir nos demais.

\section{Elegendo o estilo apropriado}

Para um grupo de seguidores, representados no grau R1 de maturidade em uma tarefa específica é apropriado prover-lhe uma boa quantidade de direção, mas baixo suporte. Uma palavra que descreve este estilo específico de liderança é "comunicativa" porque comunica aos seguidores o que fazer e como fazer. Este estilo é apropriado quando um indivíduo ou grupo está baixo em habilidades e disposição (R1) e necessita de direção. Outras palavras para descrever este estilo de liderança são "guiando", "dirigindo" ou “estruturando".

\section{Harmonizando um Inativo R1 com um Instrutivo S1}

O Quadro 2 resume o estilo Instrutivo (S1) e apresenta a descrição das ações eficientes e ineficientes deste estilo diante de um grau de maturidade (R1). 
Quadro 2- Estilo de liderança Instrutivo (S1)

\begin{tabular}{|l|l|l|}
\hline Ações do estilo instrutivo & Efetividade & Inefetividade \\
\hline Especifica que, quem, quando, onde e como. & Comunicando. & Solicitando. \\
Definição de rol. & Guiando. & Degradando. \\
Comunicação unidirecional predominante. & Dirigindo. & Doando \\
Decisões do líder. & Estabelecendo & Atacando. \\
Estreita supervisão e responsabilidade. & & \\
Abundantes instruções. & & \\
Simplifica e especifica as coisas. & & \\
\hline
\end{tabular}

\section{Harmonizando um Reativo R2 com um Persuasivo S2}

Este estilo de liderança facilita o diálogo e a explicação para ajudar às pessoas a compreender o que o líder quer. Se um líder simplesmente diz: "fica na porta e observa as pessoas que entram" está “comunicando". Este estilo não deixa opção ao seguidor de pedir explicações sobre o que deve fazer. Se o líder lhe diz: "Eu apreciaria muito se você ficasse na porta para guiar as pessoas à sala de aula, pois que elas podem estar desorientadas" isto seria um exemplo de "diálogo bidirecional". Este estilo permite ao seguidor solicitar esclarecimentos sobre sua tarefa.

A orientação às tarefas descreve o comportamento que explica o que, como, quando, onde e quem. O porquê não está incluído porque ele é uma ponte entre o comportamento direcionado as tarefas e às relações. Uma das diferenças entre "dizendo" e "instruindo" é a resposta ao "por que". Outras palavras para o estilo Persuasivo S2 incluem "explicação, persuasão e esclarecimentos" a Figura 1, resume o estilo "persuasivo" e apresenta a descrição do estilo efetivo e inefetivo frente a uma maturidade de grau (R2).

Na Quadro 3 se resume o estilo persuasivo (S2) e se apresenta a descrição das ações eficientes e ineficientes deste estilo ante um grau de maturidade (R2). 
Quadro 3- Estilo de liderança Persuasivo (S2)

\begin{tabular}{|l|l|l|}
\hline Ações do estilo persuasivo & Efetividade & Inefetividade \\
\hline Estável como, que, quando, onde e por que. & Comunicando. & Manipulando. \\
Explica as decisões e dá oportunidade de pedir & Explicando. & Predicando. \\
explicações. & Detalhando. & Defendendo. \\
Diálogo bidirecional. & Persuadindo. & Racionalizando. \\
Decide. & & \\
Explica o rol de seus seguidores. & & \\
Diagnostica o grau de habilidade dos seguidores. & & \\
Reforça os baixos resultados. & & \\
\hline
\end{tabular}

\section{Harmonizando S3 com R3}

A maturidade de grau R3 inclui pessoa ou grupo que tem capacidade e disposição, mas por alguma razão sua motivação é baixa. Isto se pode dever a um supervisor ineficiente que esgotado ao seguidor com seu comportamento e o torna apático. O estilo apropriado de liderança é aquele que oferece uma comunicação em ambos os sentidos e um apoio moderado aos seguidores. Quando o grupo já está demonstrando capacidade para desempenhar a tarefa não é necessário redundar sobre o que fazer, onde fazer ou como fazer. A discussão, o apoio e facilitação pode ser o estilo mais apropriado para resolver os problemas e abater a apreensão dos seguidores. Outras descrições deste estilo de liderança incluem "colaborando, facilitando, e comunicando". Cada um destes termos implica alta orientação às relações e baixa orientação às tarefas. Na Figura 1, se resume o estilo participativo e apresenta uma palavra para o efetivo ou inefetivo enfoque da maturidade tipo R3.

Na Quadro 4 se resume o estilo participativo (S3) e se apresenta a descrição das ações eficientes e ineficientes de este estilo ante um grau de maturidade (R3).

Quadro 4- Estilo de liderança participativo (S3)

\begin{tabular}{|l|l|l|}
\hline Ações do estilo participativo & Efetividade & Inefetividade \\
\hline Apóia ao começo. & Participando. & Patrocinando. \\
Escuta ativamente. & Animando. & Moderando. \\
Os seguidores decidem. & Apoiando. & Condescendendo \\
Comunicação bidirecional e compromisso do & Dando poder. & Pacificando. \\
líder. & Delega poder & \\
Apóia a assunção de riscos. & & \\
Elogia o desempenho. & & \\
Alaga e fomenta confiança. & & \\
\hline
\end{tabular}




\section{Harmonizando Interativo S4 e Delegatório R4}

O indivíduo ou grupo se caracterizam por ser hábeis e dispostos, têm suficiente oportunidade de praticar e se sentem confortáveis sem a direção do líder.

Não é necessário prover-lhes direção sobre onde, quando ou como e porque os seguidores já têm a habilidade. Tampouco é necessária a ênfase em animar ou apoiar ao grupo dado que tem confiança, estão comprometidos e motivados. O estilo apropriado é deixar-lhes trabalhar livremente com um objetivo claro. Este estilo se chama "delegando". Outras palavras para este estilo de liderança são "observando e monitorando".

$\mathrm{Na}$ quadro 5 se resume o estilo delegatório (S4) e se apresenta a descrição das ações eficientes e ineficientes deste estilo ante um grau de maturidade (R4).

Quadro 5- Estilo de liderança Delegatório (S4)

\begin{tabular}{|c|l|l|}
\hline Ações do estilo delegatório & Efetividade & Inefetividade \\
\hline Delega tarefas & Delega & Abandona \\
Instruções gerais & Observa & Descuida \\
Seguidores tomadores de decisão & Confia & Evita \\
Supervisão relativamente suave & Designa & Retira \\
Seguimento de atividades & & \\
Reforça os resultados & & \\
Permanece acessível & & \\
\hline
\end{tabular}

\section{Resumo de graus de maturidade e estilos de liderança}

Na Quadro 6, se apresenta uma síntese dos graus de maturidade dos seguidores e os estilos de liderança apropriados em cada situação.

Quadro- 6. Estilos de liderança apropriados aos graus de maturidade.

\begin{tabular}{|l|l|}
\hline Grau de maturidade & Estilo de liderança apropriado \\
\hline R1: Baixa maturidade & S1: Comunicador \\
Inábil e indisposto ou inseguro & Alta orientação às tarefas e baixas relações \\
\hline R2: Baixa ou moderada maturidade & S2: Persuasivo \\
Inábil, mas disposto ou seguro. & Alta orientação às tarefas e às relações \\
\hline R3: Moderada ou alta maturidade & $\begin{array}{l}\text { S3: Participativo } \\
\text { Alta orientação às relações e baixa orientação às } \\
\text { Hábil mas indisposto ou inseguro }\end{array}$ \\
\hline R4: Alta maturidade & $\begin{array}{l}\text { S4: Delegatório } \\
\text { Hábil e disposto ou seguro }\end{array}$ \\
\hline
\end{tabular}


A liderança situacional não somente sugere o estilo mais provável de liderança para os diferentes graus de maturidade, como indica a probabilidade de êxito de outros estilos se o líder é incapaz de usar o estilo sugerido.

A probabilidade de êxito de cada um dos quatro estilos para os quatro graus de maturidade, depende de qual longe esteja eleito o estilo de maior probabilidade ao largo da curva de estilos de liderança no modelo (Figura 1).

O grau de maturidade dos seguidores varia desde R1 até R4. Cada um destes graus requer um estilo de liderança apropriado. Não obstante, o líder pode aplicar outros estilos, mas terá menores probabilidades de êxito em influir nos seguidores. No Quadro 7 se indica o estilo apropriado e suas opções com probabilidade decrescente de êxito. Por exemplo, R1 requer de S1 como estilo apropriado, mas o líder pode usar como segunda opção um estilo S2 com menor probabilidade de êxito, e assim sucessivamente S3 e S4.

Quadro 7- Grau de maturidade ou probabilidades de êxito dos estilos de liderança

\begin{tabular}{|l|l|l|l|l|}
\hline Seguidores & \multicolumn{4}{|l|}{$\begin{array}{l}\text { Estilos de liderança segundo sua probabilidade de } \\
\text { exito }\end{array}$} \\
\hline Maturidade & $\begin{array}{l}\text { Primeira } \\
\text { opção }\end{array}$ & $\begin{array}{l}\text { Segunda } \\
\text { opção }\end{array}$ & $\begin{array}{l}\text { Terceira } \\
\text { opção }\end{array}$ & $\begin{array}{l}\text { Quarta } \\
\text { opção }\end{array}$ \\
\hline R1 & S1 & S2 & S3 & S4 \\
\hline R2 & S2 & S1 & S3 & S4 \\
\hline R3 & S3 & S2 & S4 & S1 \\
\hline R4 & S4 & S3 & S2 & S1 \\
\hline
\end{tabular}

Desta forma, nos quadros anteriores são apresentadas as características dos quatro estilos de liderança e as ações de êxito e de não-êxito associadas com cada estilo.

Na liderança situacional é o seguidor quem determina o comportamento apropriado do líder. O seguidor pode assumir qualquer tipo de comportamento dependendo de sua maturidade. O comportamento do seguidor determina o comportamento do líder. O modelo de liderança situacional permite aplicar este princípio em casa, no escritório e em qualquer classe de situação interpessoal, por exemplo, quão fácil resultaria a paternidade se as crianças se 
dessem conta que a mãe e o pai não determinam e controlam seu comportamento, mas que eles (as crianças) determinam o comportamento dos pais.

É pertinente perguntar: por que um estilo de liderança, que não é nosso estilo natural, é freqüentemente o mais efetivo? A razão é que nosso estilo natural é aprendido e ainda que aparentemente seja de êxito, é um caso particular e, portanto sua probabilidade é limitada. Isto não significa que não há estilos pessoais de êxito. A história nos oferece muitos exemplos destes casos. Infelizmente a história não conta os fracassos dos casos particulares que, sem dúvida, contribuíram com seu modesto êxito.

Um estilo "médio" arquétipo de comportamento de sucesso em situações gerais está baseado em distribuições normais de êxito em numerosos casos, quem dizer, tem maior probabilidade de dar certo em situações gerais.

A liderança situacional não é uma prescrição de regras duras e breves. Nas ciências do comportamento não há regras. A liderança situacional faz sua melhor contribuição às ciências do comportamento instrumentando a forma de melhorar as probabilidades de êxito dos gerentes, diretivos, chefes, pais, supervisores em sua tarefa de influenciar sobre os demais.

\section{Aplicação da liderança situacional}

Usando o modelo de liderança situacional o líder deve ter clareza que não há uma forma ideal para influenciar sobre os demais. E ainda, todo comportamento de um líder pode ser mais ou menos efetivo dependendo do grau de maturidade da pessoa que ele está tentando influenciar. O modelo sugere seguir o processo de diagnóstico do grau de maturidade, adaptação mediante a seleção de estilos de liderança de alta probabilidade e comunicação destes estilos efetivamente para influir no comportamento.

A liderança situacional supõe que uma direção forte (orientação às tarefas) frente a seguidores com baixa maturidade é apropriada se eles são produtivos. Em forma similar sugere que um incremento na maturidade das pessoas deveria ser valorizado e oferecido o 
incremento de reforço positivo e do apoio sócio-emocional. Finalmente à medida que os seguidores adquiram altos graus de maturidade, o líder deveria responder não só com uma diminuição do controle como também diminuição das relações. As pessoas com alto grau de maturidade não necessitam apoio sócio-emocional na mesma proporção que necessitam maior liberdade. Isto não significa que seja menor a confiança e a amizade entre o líder e o seguidor, aliás, é maior, mas suas manifestações são menores.

Uma forma de manifestar confiança a seguidores com alta maturidade é assumindo um estilo de liderança respeitoso de sua autonomia e a livre determinação.

A liderança situacional é um modelo provado durante muito tempo e em diversas situações e culturas. Sua utilidade não é questionável como instrumento de gestão de eficiência e eficácia das organizações de todo tipo.

\subsubsection{A liderança em Enfermagem}

Estudar liderança e entender seu significado no contexto de Enfermagem é um desafio, entretanto, há muitos investigadores nesta profissão que têm feito valiosos aportes.

Enfermagem como profissão, é uma prática social em que seus membros devem preparar-se formalmente permitindo-lhes a inserção nas normas do órgão jurídico político do Estado. Gransci (1982) considera que, como premissa fundamental, as relações entre educação e sociedade evoluem historicamente, pelas contradições entre os grupos e classes socialmente antagônicas. A educação é um elemento normativo do modo de produção predominante, como tal tem a educação ou a produção tem ingerência na formação dos profissionais da Enfermagem, os quais representam uma profissão resultado das relações sociais que tem evoluído como prática social para oferecer serviço de saúde à população.

García e Monroy (2004) referem-se à liderança como a estratégia inerente, ao reordenamento dos processos de trabalho das diversas equipes, nas organizações onde atua a enfermagem (hospitais, centros de saúde, escolas de enfermagem, entre outros) e a sua 
inserção em equipes multi e interdisciplinares. Para tanto, devem contar com conhecimento básico de enfoques e teorias de liderança para poder contribuir nos projetos coerentes e adequados à realidade das organizações que a sociedade requer do campo da saúde, participando na tomada de decisões, impulsionando o trabalho em equipe, cooperação, habilidades de comunicação, dando poder, delegação, participação em todos os sentidos, para o processo de mudança organizacional, para melhorar a atenção do cuidado da saúde para a população, com um paradigma dialético aberto às mudanças, e ao contingente.

A liderança em Enfermagem tem antecedentes sólidos, pois existem valiosas investigações que ajudam a fortalecer o fenômeno para compreendê-lo. Santos (1999) refere que o predomínio do modelo gerencial burocrático e funcional compreendido como autoritário e inflexível, apresenta como conseqüência a insatisfação das pessoas no trabalho, causada pela rotina, opressão da liberdade e da criatividade humana, ressentimento e alta rotatividade do pessoal.

De outro lado, Higa e Trevizan (2005) referem que há evidência da necessidade de transformação, na prática administrativa e na liderança em Enfermagem, do ponto de vista gerencial, assim como, das descrições da realidade e, indicam a importância da aprendizagem da liderança em nosso meio modificando os paradigmas da clássica Administração e, por conseguinte da liderança.

Ferraz (1998) refere que a Enfermagem brasileira, ainda se encontra sob o método funcionalista de organização no atendimento assistencial, predominando o modelo autocrático de liderança, também, identificou que as enfermeiras se fundamentam em teorias administrativas tradicionais nas quais predomina a dominação/subordinação acentuando a divisão técnica e social do trabalho. Ela aponta que situações como estas limitam a superação desta prática. A mesma autora, fazendo uma análise da disciplina de Administração dos cursos de graduação em Enfermagem em São Paulo, evidenciou que a formação ainda está na 
época do perfil funcionalista e mecanicista que aborda alguns conceitos de liderança em seu conteúdo temático.

Simões (2001) descreve alguns fatores relacionados com a situação de liderança do enfermeiro inserido no hospital e observou que o significado de ser líder para este profissional, se relaciona com trabalho e responsabilidade. Dentro das dificuldades encontradas destacam-se as relacionadas aos seus atributos e às relações interpessoais. Mas, também, observou a existência de satisfação com relação ao conhecimento adquirido durante o período acadêmico para o desenvolvimento das funções de líder.

O desenvolvimento da Enfermagem visa nova forma de pensar e de atuar o que nos leva ao interesse de estudar a concepção da liderança. O World Health Organization WHO (1985) fez a primeira avaliação da política de "Saúde para Todos no ano 2000” considerando necessário o papel dos líderes para a implantação de estratégia de Atenção Primária de Saúde criado em 1978 em Alma Ata. Entre os acordos propuseram criar uma comissão com que tivesse a iniciativa do desenvolvimento da liderança, tornando possível a compreensão da meta de "Saúde para Todos". O objetivo da estratégia foi que a massa da população compreendesse este movimento e benefício, e, sobretudo desenvolvesse recursos humanos para dinamizar o processo e tornar possível o avanço com apoio e suporte mediante uma rede mundial, para o alcance dos objetivos, sendo proposta a intervenção do Conselho Internacional de Enfermeira (CIE) por sua maior proximidade social com a população.

O CIE (1985) mediante o Conselho de Representantes Nacionais reunido na cidade de Tel Aviv, Israel propôs que a preparação de administradores de Enfermagem fosse uma das prioridades do quatriênio (1985 a 1989) e recomendou à Junta Diretiva que confiasse a tarefa ao Comitê de Serviços Profissionais (CSP), estes entenderam que a Resolução devia ampliarse e incluir a liderança e a administração de serviços de saúde, no lugar de limitar-se unicamente à Administração de Enfermagem. 
O Conselho Internacional de Enfermeiras CIE (1987), aprovou as propostas do Comitê de Serviços Profissionais (CSP) criando um programa para o Congresso Quadrienal do CIE centralizado na liderança de enfermagem em matéria de planificação e administração de serviços de saúde, assim, considerando a liderança além dos confins da Enfermagem. “...Em 1988, a Junta aprovou o plano, em longo prazo...", o campo de ação para desenvolver a liderança proposta pelo CSP (1987) e, reconhecendo que havia que dar prioridade à Enfermeira Administradora nos sistemas de Saúde (CIE, 1987).

Em 1987 se ocorreu uma reunião de administradores, contando-se com a participação de peritos no exercício e ensino da Administração de Enfermagem. Nesta reunião foi identificada a necessidade de contar com enfermeiras administradoras líderes e realizar mudanças no papel e nas funções da enfermagem como administradora. Em 1989, em Seul, o CIE aprovou a declaração oficial sobre Administração de Enfermagem com ênfase no tópico de liderança (CIE, 1989).

A partir da década de 90 o CIE iniciou a preparação e formação do enfermeiro administrador com ênfase na conceitualização da liderança. O CEI (1990a) considerou como necessidade o fortalecimento da liderança em suas associações nacionais; portanto, elaborou um projeto denominado "Liderança para a mudança", o qual foi desenvolvido nas associações de cada país.

$\mathrm{Na}$ América Latina, também se tem trabalhado com o conceito de liderança em Enfermagem, prestando-se a múltiplas interpretações o que tem levado a confusão e, talvez, atraso e dificuldade para a utilização de estratégias para seu exercício (MANFREDI, 1997).

O CIE (2005) é um organismo que desenvolve estratégias para a preparação e capacitação mediante educação contínua de liderança para ter uma clara noção da perícia e procedimentos necessários com relação ao fenômeno de liderança. Deduzem que as pessoas serão potencialmente aptas para desenvolver sua prática correspondente com a devolução de 
informação sistemática sobre a prestação dos serviços, para o qual recorreriam a projetos administrativos, mentores e pessoal homólogo.

No México este projeto se desenvolveu por vários anos pelo Colégio Nacional de Enfermeiras, mediante oficinas. A percepção que se tem é de insuficiência sem alguma mudança concreta. As mudanças são lentas e, existe na maioria dos casos, pouco apoio das autoridades para aquelas pessoas que desejam aplicar as mudanças no desempenho da liderança.

Becerril (2004) refere que a principal reflexão dos profissionais de enfermagem se fica na debilidade política que gera uma liderança insuficiente e inadequada. Percebe-se uma liderança funcionalista nas organizações de saúde, predominando o estilo de liderança autocrático, na maioria de casos se guiam pelas teorias de administração tradicionais como a taylorianas, fayolistas, entre outras.

No México, para o exercício da profissão, não se conta com a exigência de estar registrado em um colégio de profissionais de enfermagem, como acontece em outros países, correspondendo a um registro voluntário, evidenciando a falta de formação de grupo profissional e por conseqüência de equipe. Também, não se observa o interesse em participação política, sendo a justificativa para tal a excessiva carga de trabalho nas instituições, baixos salários, situações de gênero e compromisso familiar, falta de estímulo por parte dos colégios, poucos ou nulos benefícios quando se participa, feitos que geram um círculo vicioso. Nos próprios colégios acontecem situações, em alguns casos, que os líderes em turno, se apropriam do poder e não permitem a participação de novos líderes. Estas e outras situações geram baixas forças de agremiação de enfermagem. Becerril (2004 ) refere que tudo isto está relacionado ao pouco interesse no alcance de uma reivindicação social e por outro lado, ao trabalho colegiado de baixo impacto. 
No país, existem várias organizações onde se executa a liderança observável, por exemplo, o Colégio Nacional de enfermeiras (CNE); a Federação Mexicana de Associações de Faculdades e Escolas de Enfermagem (FEMAFEE); a Comissão Interinstitucional de Enfermagem (COIE); a Comissão Interinstitucional para a Formação de Recursos Humanos em Saúde (CIFHRS); o Conselho Mexicano Certificação em Enfermagem (COMACE); o Colégio Mexicano de Licenciados em Enfermagem (COMLE); a Conferência Superior Maiores de Religiosas de México (COSMREM); o Colégio Nacional de enfermeiras Militares (CONEM); a Sociedade Mexicana de Saúde Pública; a Associação de Enfermeiras Cirúrgicas do Distrito Federal e Área Metropolitana e Colégios Estatais em cada estado da República Mexicana. Além dos cargos diretivos que a Enfermagem ocupa em cada instituição do Setor Saúde.

Becerril (2005) identificou que a liderança em Enfermagem é um assunto controvertido e que tem se intensificado nos últimos vinte anos. Freqüentemente se afirma que não há líderes em Enfermagem em nosso país. Isto é dito pelas próprias enfermeiras, quem concebem a liderança como um exercício que permite a consecução de objetivos comuns no grupo de enfermagem, com um guia adequada e oportuna para os seguidores. As enfermeiras identificam poder reduzido. As organizações sempre se dão pelo poder, as pessoas sempre trabalharam mais em função da adoração de sua personalidade e de sua pessoa do que da melhoria da Enfermagem. Não criaram uma consciência de grupo, nem buscaram o desenvolvimento grupal.

Algumas enfermeiras consideram que existem números insuficientes de lideres que saibam orientar os grupos em direção correta à prática e a educação da Enfermagem, que desenhem estratégias dentro da estrutura social e motivem às enfermeiras à mudança. Um dos melhores meios para a formação de líderes é a educação, ainda que as oportunidades tenham sido limitadas. 


\subsubsection{A conduta tipo a do líder}

A proposta do presente estudo é estudar a liderança em Enfermagem, mas, é importante entender que a liderança é desenvolvida por pessoas e, as pessoas, cada uma tem sua conduta. Por tal razão se pretende identificar algumas características desenvolvidas pelas pessoas que ocupam cargos de direção nas organizações hospitalares, e desenvolvem um tipo de conduta (FRIEDMAN; ROSENMAN, 1976).

Friedman e Rosenman (1976) referem que a conduta é um conjunto complexo de ações e emoções, que caracterizam os indivíduos, que se encontram comprometidos com uma luta relativamente crônica, para obter um número limitado de coisas do entorno, pobremente definidas, no menor tempo e, se é necessário, contra os efeitos opositores de outras coisas ou pessoas no mesmo meio ambiente.

Queendom (2005) refere que este grupo afirma um comportamento Tipo A. Estes se caracterizam por intensa atitude ao alcance de metas, ou êxito e pela competitividade. Este tipo de conduta manifesta uma persistente necessidade de reconhecimento externo e complacência se envolve em diversas funções que podem levar a sérias restrições de tempo e tende à aceleração física e mental em um estado constante de vigilância e controle.

Simon e Kertsz (2003) mencionam que apesar destas características há o desenvolvimento de muitos profissionais empreendedores, com potencial para grandes realizações. Sendo que a conduta Tipo A deve pagar um alto preço por isso.

Certas características desta conduta podem inibir a qualidade de vida e ainda fragilizar a saúde, por exemplo, suas metas, com freqüência, estão deficientemente definidas, tomandoas difíceis de alcançar, é um caminho para o fracasso o que lhes causa ansiedade. Outra característica é a manifestação do impulso a exigir e a criticar, sempre em busca da perfeição de si mesmo e dos demais. Estes aspectos negativos vão acompanhados de pressão, hostilidade e impaciência que terminam em sensação de culpa, arrependimento e ansiedade. 
Lankton (2004) refere que a conduta tipo A está motivada por fontes externas, tais como a recompensa material e a apreciação de outros. A pessoa tipo A experimenta uma sensação de oposição e apreensão que os mantém em estado de alerta, que em forma constante altera a felicidade e rompe o equilíbrio pessoal. Torres (1995) acrescenta que o comportamento tipo A está altamente ligado com os riscos de doenças cardiovasculares, stress, que parecem reduzir-se quando se modera tal comportamento. Os profissionais que apresentam as características de tipo A, seriam mais felizes e saudáveis, sempre que perfilassem melhor os traços de sua conduta conforme apresenta Moreno (2005). As pessoas com conduta tipo A, podem ter êxito sem sacrificar seu bem-estar emocional, mas é altamente propensa ao stress, pelo qual se chama também personalidade estressante.

Considerando que o estilo de liderança depende, entre outros fatores, da conduta do líder, do ambiente e dos seguidores ou pessoas a cargo, é pertinente a consideração da orientação da personalidade dos diretivos de enfermagem em direção a conduta de tipo A. 


\section{FORMULAÇÃO DAS INTERROGAÇÕES, OBJETIVOS E HIPÓTESES}


O objetivo, do presente estudo, é investigar se há relação entre os estilos de liderança, graus de maturidade do modelo de Hersey e Blanchard (1988) e o traço de Conduta Tipo A, de acordo a Friedman; Rosenman (1976), que exercem os dirigentes de enfermagem dos hospitais gerais da cidade do México. A seguir apresenta-se as questões norteadoras da investigação.

\subsection{Formulação das questões de pesquisa}

Há relação entre os estilos de liderança, os graus de maturidade e o traço de conduta tipo A dos profissionais de enfermagem que desempenham cargos diretivos nos hospitais gerais da secretaria de saúde da cidade do México Distrito Federal?

Quais são os estilos da liderança percebidos pelos profissionais de enfermagem que desempenham cargos diretivos nos hospitais da Secretaria de Saúde da cidade do México, Distrito Federal?

Quais são os graus de maturidade dos seguidores, percebido pelos enfermeiros diretivos dos hospitais da Secretaria de Saúde da cidade do México, Distrito Federal?

Qual são os traços de conduta Tipo A percebidos em seu comportamento, pelos enfermeiros diretivos dos hospitais da Secretaria de Saúde da cidade do México, Distrito Federal? 


\subsection{Objetivos}

\subsubsection{Objetivo Geral}

Analisar e relacionar a opinião dos dirigentes de enfermagem, sobre os estilos de liderança, a maturidade dos seguidores e o Traço da Conduta Tipo A, segundo o modelo de Hersey e Blanchard (1988) e a teoria de Friedman e Rosenman (1976), nos hospitales generais da cidade de México, Distrito Federal.

\subsubsection{Objetivos específicos}

- Identificar os estilos de liderança, segundo o modelo de Hersey e Blanchard (1988), de acordo com a opinião dos dirigentes de enfermagem dos hospitais gerais da Secretaria de Saúde da Cidade de México, Distrito Federal.

- Identificar a opinião dos dirigentes de enfermagem sobre os graus de maturidade de seus colaboradores, segundo o modelo de Hersey e Blanchard (1988).

- Identificar a opinião dos dirigentes sobre o Traço de Conduta Tipo A dos dirigentes de enfermagem dos hospitais gerais da Secretaria de Saúde da Cidade de México, Distrito Federal. 


\subsection{Hipótese geral}

Foram considerados quatro tipos de hipóteses para correlacionar cada um dos estilos da liderança: Instrutiva (S1), Persuasiva (S2), Participativa (S3) e Delegativa (S4); com a maturidade dos seguidores: Inativo (R1), Reativo (R2), Pró-ativo (R3), Interativo (R4) e o Traço de Conduta Tipo A (C) dos profissionais de enfermagem que exercem cargos de dirigentes.

\section{HIPOTESE GERAL $(\mathrm{Ha}): \quad \mathrm{L}=\mathrm{f}(\mathrm{C}, \mathrm{R})$}

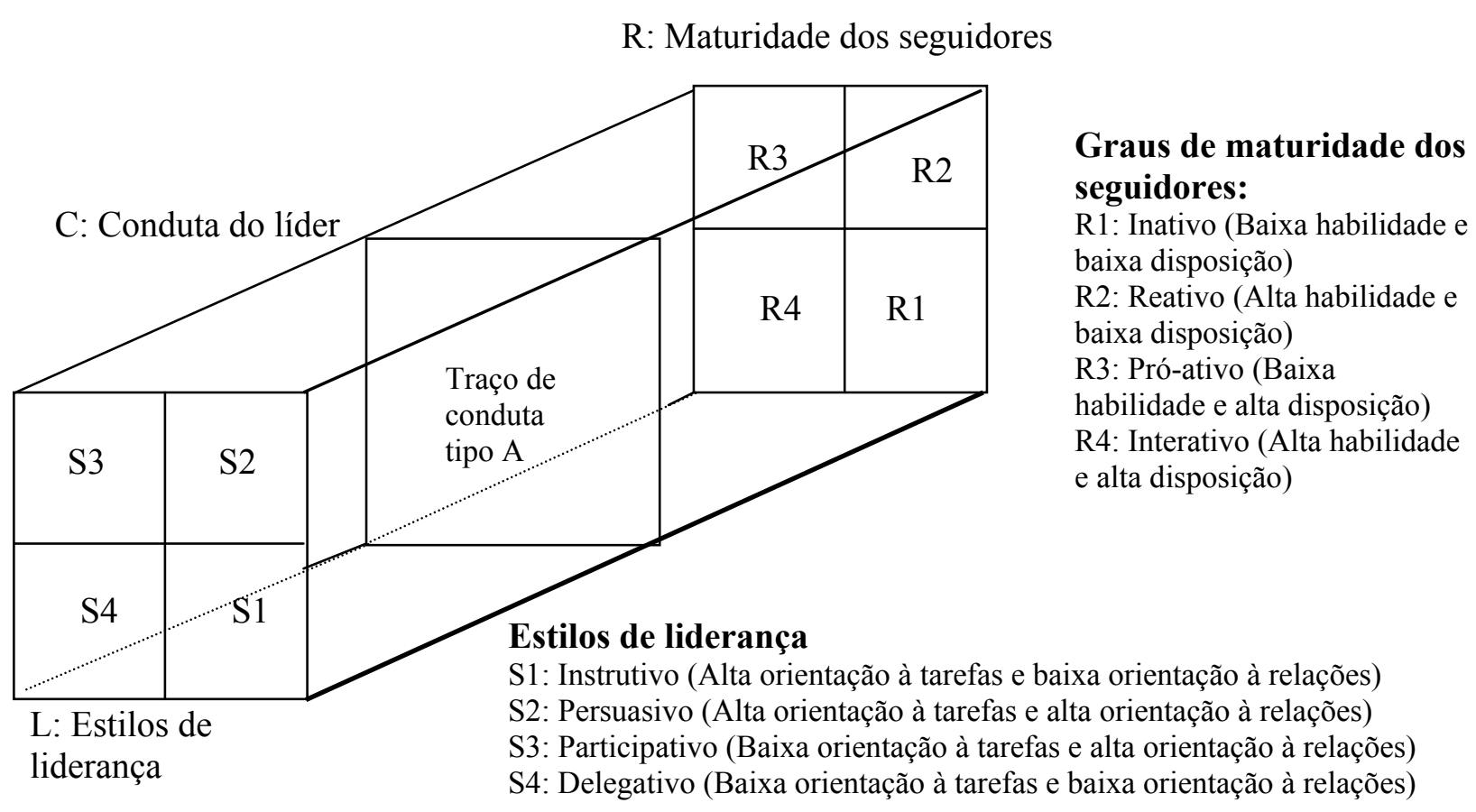

Figura 2 - Hipótese Geral

Grupo no 1 - Correlação dos estilos de liderança S1, S2, S3 e S4 com os graus de maturidade dos seguidores R1, R2, R3, R4 e o traço de conduta Tipo A (C) dos profissionais de enfermagem que ocupam cargos de dirigente. 
Hipótese:

$$
\begin{aligned}
& H\left(a_{11}\right): S 1=f(R 1, R 2, R 3, R 4, C) \\
& H\left(a_{12}\right): S 2=f(R 1, R 2, R 3, R 4, C) \\
& H\left(a_{13}\right): S 3=f(R 1, R 2, R 3, R 4, C) \\
& H\left(a_{14}\right): S 4=f(R 1, R 2, R 3, R 4, C)
\end{aligned}
$$

Grupo no 2 - Correlação dos estilos de liderança S1, S2, S3 e S4 com os graus de maturidade dos seguidores R1, R2, R3 e R4.

Hipótese:

$$
\begin{aligned}
& H\left(a_{21}\right): S 1=f(R 1, R 2, R 3, R 4) \\
& H\left(a_{22}\right): S 2=f(R 1, R 2, R 3, R 4) \\
& H\left(a_{23}\right): S 3=f(R 1, R 2, R 3, R 4) \\
& H\left(a_{24}\right): S 4=f(R 1, R 2, R 3, R 4)
\end{aligned}
$$

Grupo no 3 - Correlação dos estilos de liderança S1, S2, S3 e S4 com o Traço de Conduta Tipo A (C).

Hipótese:

$$
\begin{aligned}
& H\left(a_{31}\right): S 1=f(C) \\
& H\left(a_{32}\right): S 2=f(C) \\
& H\left(a_{33}\right): S 3=f(C) \\
& H\left(a_{34}\right): S 4=f(C)
\end{aligned}
$$

Grupo $\mathbf{n}^{\mathbf{0}} \mathbf{4}$ - Correlação segundo pares os estilos de liderança e o grau de maturidade dos seguidores: S1 e R1, S2 e R2, S3 e R3, S4 e R4:

\section{Hipótese:}

$$
\begin{aligned}
& H\left(a_{41}\right): S 1=f(R 1) \\
& H\left(a_{42}\right): S 2=f(R 2) \\
& H\left(a_{43}\right): S 3=f(R 3) \\
& H\left(a_{44}\right): S 4=f(R 4)
\end{aligned}
$$


Formulação das Interrogações, Objetivos e Hipóteses 
3. TRAJETÓRIA METODOLÓGICA 
A trajetória metodológica é uma parte complexa da investigação, na qual se deve ter clareza na exposição de métodos e técnicas que são utilizadas com relação ao marco teórico e o objeto de estudo. Nesta parte do estudo se descrevem o tipo de estudo, campo do estudo, sujeitos do estudo, os critérios de inclusão, considerações bioéticas, etapas para a coleta de dados, da amostra, as estratégias para a coleta de dados no campo empírico, os instrumentos aplicados e procedimentos utilizados na análise dos dados.

Neste estudo se pretende abarcar a socialização dos conhecimentos implícitos que reflitam as opiniões comuns na população analisada, em sua atividade diária, ou seja, é a percepção dos dirigentes de enfermagem sobre os principais aspectos da liderança. A este respeito Miguélez (2004) afirma: “o espírito humano não reflete o mundo, mas o que o traduz por meio de todo um sistema neuro-cerebral". Morin (2001) acrescenta: "nossas idéias não são reapresentações objetivas da realidade, mas traduções da realidade".

\subsection{Tipo de estudo}

É um estudo descritivo correlacional de dados quanti-qualitativa. A pesquisa pretende descrever os fatos e fenômenos de determinada realidade Triviños (1987). Chama-se correlacional porque se estabelecem relações entre variáveis dependentes e independentes, é quantitativo porque se concretizam as correlações entre variáveis dos conceitos investigados mediante respostas numéricas que se expressam em coeficientes de correlações e determinação qualitativas porque se objetivou conhecer a opinião dos dirigentes de enfermagem sobre o estilo de liderança que praticam, assim como o traço de conduta tipo A e, a habilidade e boa vontade de seus seguidores para realizar tarefas e relações.

\subsection{Campo do estudo}

O estudo se desenvolvido na Cidade do México, Distrito Federal. A Cidade de México foi fundada no ano de 1325 pelos astecas ou mexicas, que a denominaram "Tenochtitlan" (lugar de água e ilhas) (PÉREZ, 2003). Naquela época o sacerdote Ténoch, (Chefe religioso e 
político) e o primeiro imperador Acamapichtli não imaginariam que esta cidade, futuramente, seria a capital do país de México. Desde sua fundação até a atualidade a cidade tem crescido em história e população, A cidade de México, junto com a zona metropolitana, constitui a maior concentração humana da República Mexicana. Representa, também, o mais importante centro governamental, industrial, comercial, financeiro e educativo. Conta com 18,5 milhões de habitantes em a região da conturbação, dos quais mais de 8.520.090, segundo México (1999b) pertence ao Distrito Federal (DF) e dispõe de um território de $1.547 \mathrm{Km}^{2}$.

A estrutura do governo no DF está composta por uma área central e 16 delegações políticas com igual hierarquia, cujos governos de as delegações são eleitos democraticamente a cada três anos. O representante do governo no DF é eleito a cada seis anos se mostra um mapa da região (LAURELL, 2004).

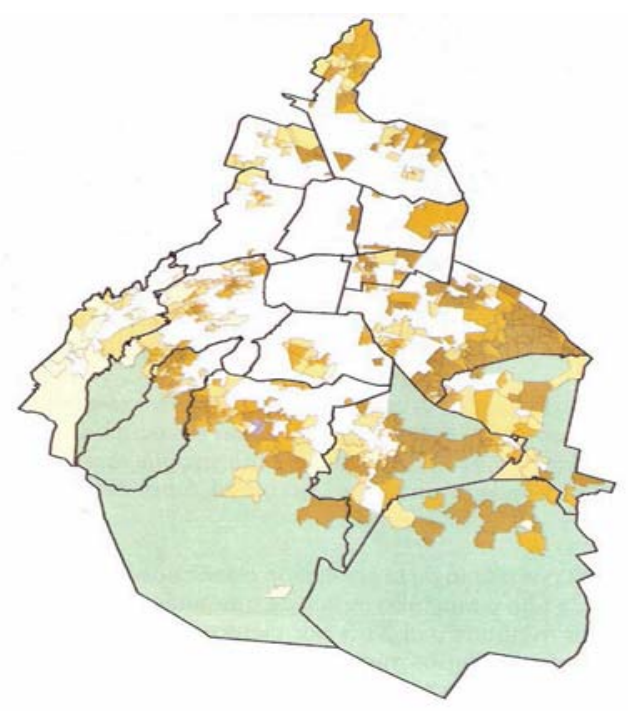

Figura 3 - Delimitação geográfica por delegação política, Distrito Federal.

O Distrito Federal conta com um complexo Sistema de Saúde (descrito no aporte teórico ponto 1.1.5), sua estrutura hospitalar consta de 115 hospitais. O número total de enfermeiras, segundo dados do SSDF, México (1999) corresponde a 30.637, cuja distribuição pode ser observada na Tabela 2, a seguir. 
Tabela 1 - Profissionais de Enfermagem Designados às Organizações do Sistema de Saúde do Distrito Federal (SSDF)

\begin{tabular}{lrrrrrrr}
\hline Pessoal & Total & IMSS & ISSSTE & PEMEX & SSDF & SM & STC \\
\hline Enfermeiros & 30.637 & 17.587 & 6.139 & 751 & 5.861 & 175 & 94 \\
Auxiliares & 11.251 & 6.487 & 2.176 & 291 & 2.170 & 88 & 39 \\
Gerais & 12.902 & 6.926 & 2.441 & 275 & 3.109 & 76 & 45 \\
Especializadas & 5.822 & 3.624 & 1.454 & 146 & 582 & 7 & 9 \\
\hline Outras & 662 & 550 & 68 & 39 & 0 & 4 & 1 \\
\hline Fonte & Mérico
\end{tabular}

Fonte: México, Instituto Nacional de Estatística Geografia e Informática, Anuário estadístico, 2005.

\subsection{Definição do universo empírico}

O universo empírico corresponde a 115 hospitais de os quais 65 são de especialidade y 50 são hospitais gerais. O presente estudo contou com todos os hospitais gerais com a participação de dirigentes de enfermagem de cada hospital geral (cada hospital só tem um dirigente de enfermagem) localizados na Cidade do México. Na tabela 2 mostra-se a distribuição segundo a organização na qual o dirigente do hospital estudado se encontrava inserido.

Tabela 2 - Distribuição dos Hospitais Gerais da Cidade do México, Distrito Federal.

\begin{tabular}{|l|c|c|c|}
\hline \multicolumn{1}{|c|}{ Dependência da organização } & $\begin{array}{c}\text { Número de } \\
\text { hospitais } \\
\text { gerais }\end{array}$ & $\%$ & $\begin{array}{c}\text { Número } \\
\text { de } \\
\text { dirigentes }\end{array}$ \\
\hline Secretaria de Saúde Federal (SS) & 21 & 42 & 21 \\
Secretaria de Saúde do Distrito Federal (SSDF)* & 8 & 16 & 8 \\
Instituto Mexicano de Seguro Social (IMSS) & 13 & 26 & 13 \\
Instituto de Segurança e Serviço Social para os & 8 & 16 & 8 \\
Trabalhadores do Estado (ISSSTE) & \multicolumn{1}{|c|}{50} \\
\hline Total & 50 & 100 & 50 \\
\hline
\end{tabular}

Fonte: México. Secretaria de Saúde Governo Distrito Federal. Anuário estadístico, 2006b

\subsection{Sujeitos do estudo}

Os sujeitos do estudo foram enfermeiros que ocupavam cargos dirigentes de enfermagem. Para tanto, contou-se com a participação de $100 \%$ dos dirigentes de enfermagem dos hospitais gerais do DF. Do total de 50 dirigentes, participaram 42 que pertencem às organizações SS, IMSS e ISSSTE respondendo a três questionários (Apêndice A, B e C) e, oito diretivos de enfermagem do SSDF*, que participaram de uma entrevista semi-estruturada 
(Apêndice D). A seleção de os oito dirigentes se considera o critério de ser de uma mesma dependência do governo do SSDF. Para a participação de todos contou-se, previamente, com a aceitação voluntária dos diretivos de enfermagem e o consentimento livre e esclarecido, assinado pelos entrevistados e pelas autoridades dos hospitais participantes.

\section{Critérios de inclusão}

As enfermeiras diretivas incluídas no presente estudo deveriam cumprir os seguintes requisitos: a) Independente da idade, desempenhar um cargo diretivo em algum hospital geral da Cidade de México, D. F.; b) Ter mais de seis meses no cargo; c) Ser enfermeiras de nacionalidade mexicana; d) Aceitar participar do estudo de maneira voluntária; e e) Contar com o consentimento e autorização oficial de seus diretores.

\subsection{Considerações Bioéticas}

O presente estudo seguiu a disposição do Ministério do Saúde, no Regulamento da Lei Geral de Saúde em Matéria de Investigação para a Saúde do México (MEXICO, 1987). Com base no Capítulo I Considerações Comuns:

Artigo 14 - Se ajustará aos princípios científicos e éticos que a justifiquem. Fração V Contará com o consentimento informado e por escrito dos participantes da investigação. Fração VI - O estudo será realizado por um profissional da saúde com conhecimento e experiência para cuidar a integridade do ser humano. Fração VII - O estudo deverá contar com o ditame favorável da comissão de investigação e Ética, neste caso, da Faculdade de Enfermagem de Celaya e da Universidade de Guanajuato. Apresenta-se, no Anexo, a apreciação do Comitê de Bioética, da Faculdade de Enfermagem e Obstetrícia da Universidade de Guanajuato do México.

Fração VIII - O estudo iniciará suas atividades (entrevistas) após a autorização dos diretivos das instituições. Foi autorizado por Ministro de Saúde do México e dos diretivos de cada 
hospital. Artigo 16 - A privacidade dos participantes deverá ser mantida em sigilo, podendo ser identificados unicamente quando os resultados o requeiram e os participantes o autorizem. Artigo 17 - O estudo é considerado sem risco, já que, carece de intervenção ou intenção de modificação, intencionada nas variáveis, nos instrumentos e/ou nas entrevistas semiestruturadas e não se trata de aspectos sensitivos da conduta dos participantes.

$\mathrm{Na}$ realização do estudo, foram respeitados os Princípios Éticos Básicos, segundo estabelecidos pelo Código de Bioética para os profissionais de saúde (MEXICO, 2002).

\subsection{Etapas para a coleta dos dados}

Para a coleta de dados foram percorridas as seguintes etapas:

Primeira etapa - Foram aplicados três questionários: a) questionário de estilo de liderança, b) questionário de maturidade dos seguidores e c) questionário traços de conduta tipo A do diretivo (Apêndices $\mathrm{A}, \mathrm{B}$ e $\mathrm{C}$, respectivamente). Esses questionários, já foram validados no México pela Faculdade de Administração da Universidade Nacional Autônoma de México. Para sua utilização, no presente estudo, os questionários, foram adaptados e direcionados para serem aplicados nos dirigentes de enfermagem, e os itens foram submetidos a uma análise semântica.

O objetivo da análise semântica foi verificar se todos os itens eram compreensíveis para todos os membros da população à qual o instrumento se destina (PASQUALI, 1999). O questionário sobre os estilos de liderança, publicado por Chung (1990) e baseado na proposta de Hersey, Blanchard e Johnson (2001) sofreu uma adaptação relacionada ao formato e semântica dos itens. No formato foram incluídos sete itens (dados pessoais e laborais). Ademais se mudaram termos como: diretivo por enfermagem ou enfermeira e empregado por paciente. O questionário sobre maturidade dos seguidores é uma adaptação baseada no modelo de liderança situacional de Hersey; Blanchard e Johnson (2001) e no questionário 
sobre os Traços da Conduta Tipo A, dos diretivos (adaptação de Moreno, 2005) não se considerou necessária a realização de alguma mudança.

Para fazer o pré-teste de os questionários $\mathrm{A}, \mathrm{B}$, e $\mathrm{C}$ se tomo uma amostra de conveniência composta por sete dirigentes de enfermagem, de sete hospitais de especialidades que não formaram parte da amostra do estudo. Para a seleção dos participantes desta etapa seguiram-se os critérios de inclusão propostos no estudo, assim, foram escolhido três dirigentes do Hospital da Secretaria de Saúde, dois do Instituto Mexicano de Seguridade Social, três do Hospital Instituto de Segurança e Serviço Social para os Trabalhadores do Estado, dois do Hospital da cidade do México. Os resultados mostram facilidade na compreensão dos questionários, porém, foi sugerida a mudança da palavra "supervisora" por "sub-chefe". Esta mudança não foi realizada por não ser manifesta pelas demais dirigentes e por não ser uso comum em todas as instituições.

Após a analise semântica, considerou-se os questionários aptos para sua aplicação na amostra selecionada.

Segunda etapa: foram convidados os dirigentes de enfermagem dos oito hospitais gerais de SSDF para fazer uma entrevista semi-estruturada (Apêndice D). Os potenciais participantes receberam um convite formal de participação no estudo, informação relacionada com os objetivos do estudo e, após leitura, foi pedida a assinatura do termo de consentimento livre e esclarecido (Apêndice E). Ademais, os participantes foram informados de que as entrevistas se garantindo o anonimato e caráter confidencial das informações que fossem dadas seriam gravadas em fitas cassete.

A informação obtida por meio das entrevistas semi-estruturadas (Apêndice F idioma espanhol) foi utilizada como meio de apoio para as convergências e divergências das informações obtidas por meio dos questionários $\mathrm{A}, \mathrm{B}$ e C. 
Na entrevista semi-estruturada (Apêndice D) foi considerado o referencial de Spradley (1979) e Triviños (1987) utilizados para a analises de dados qualitativos, nas etapas prévias da investigação. Foi organizada uma reunião com cada um dos oito diretivos para exposição dos objetivos da pesquisa e o registro do dia e horário das entrevistas. As entrevistas se desenvolveram no ambiente de trabalho, dos entrevistados, respeitando seu tempo de trabalho, assim, facilitando o diálogo e a interação entre o entrevistado e o investigador, assim como, foi considerada a importância da realização da entrevista em um clima de simpatia, de confiança e harmonia entre os mesmos. Foram organizadas e aplicadas as perguntas norteadoras de tipo descritivas e seguidamente realizada a transcrição das entrevistas pela pesquisadora (item 4.5). Triviños (1987) refere que, a consideração das recomendações, referidas anteriormente, e o amplo domínio do pesquisador, no enfoque no estudo e na realização de entrevistas semi-estruturadas, permite a obtenção de resultados mais fidedignos.

\subsection{Análises dos dados}

Os passos seguidos para o tratamento dos dados, obtidos por meio dos questionários, foram: captura de dados, construção de base de dados e processamentos ou analises dos dados. Os dados foram submetidos a um tratamento estatístico descritivo e tratamento inferencial utilizando a análise de regressão múltipla, para conhecer a correlações entre as variáveis dependentes: estilos de liderança (Instrutivo, Persuasivo, Participativo e Interativo) e as variáveis independentes: graus de maturidade (Inativo, reativo, pró-ativo e interativo) e o traço de conduta tipo A, mediante os coeficientes de correlação e coeficientes de determinação. Os dados da entrevista semi-estruturada se apresentam integramente e, finalmente, foi elaborado um quadro de coincidentes das quatro perguntas norteadoras.

Construiu-se uma base de dados para cada questionário (A, B e C). Obtiveram-se as análises de freqüências e medidas de tendência central; histogramas; verificação de hipóteses, dos quatro grupos, aplicando-se uma regressão lineal múltipla, a qual permitiu conhecer a 
relação entre duas ou mais variáveis independentes e, portanto, permitiu o ajuste de modelos de regressão; a obtenção de coeficientes de correlação e de determinação entre as variáveis.

\subsubsection{Processamentos dos dados}

Para a análise dos dados foi utilizado o programa estatístico SPSS (Statistical Pakage for Social Sciences 15.0). Para a verificação das hipóteses foi realizado o delineamento e aplicação de um modelo matemático geral, para cada um dos quatro grupos de hipóteses. Mediante a análise de regressão linear múltipla se obtiveram os coeficientes do modelo de correlação das variáveis (estilos de liderança, maturidade dos seguidores e Conduta Tipo A) dos modelos matemáticos: F de Snedecor, para obtenção de Coeficiente de determinação $\mathrm{R}^{2,}$; apresentados nas figuras do item 4.2. Para a interpretação do valor relativo, dos coeficientes de correlação, se elaboro a Tabela 3 que mostra a ponderação, com o propósito de conhecer o grau de incidência entre variáveis preditoras (estimação realizada de valores conhecidos, de outras variáveis, que estão relacionadas como o estilo de liderança, grau de maturidade e Conduta Tipo A).

A análise, propostas se mostram suficientes, para a comprovação das hipóteses nulas (aceitação ou rejeição), assim como, para analisar a incidência da maturidade dos seguidores e Traços Tipo A, nos estilos de liderança e o grau de explicação de cada estilo de liderança.

Finalmente, se realizou a descrição e análises dos dados obtidos por meio das entrevistas semi-estruturadas. O objetivo dessa análise foi encontrar as possíveis relações entre as variáveis do estudo dos dirigentes da SSDF, realizando-se uma descrição de cada uma das entrevistas. No Quadro 10, apresentam-se as coincidências entre os relatos orais, dos dirigentes entrevistados, e os resultados obtidos por meio da aplicação dos questionários. 


\section{ANÁLISE DOS RESULTADOS E DISCUSSÃO}


Esta etapa do estudo tem como finalidade estabelecer uma relação entre os objetivos propostos e os dados coletados. Relação que permita verificar as hipóteses propostas, assim como, ter uma idéia das características pessoais e laborais dos dirigentes.

A liderança situacional referida por Hersey, Blanchard (1988) pode ser representada pelo modelo referido no ponto 4.2.1

$\begin{array}{ll}5 & 5 \\ \mathrm{Si}= & \mathrm{f}(\mathrm{Ri}, \mathrm{C}) \\ \mathrm{i}=1 & \mathrm{i}=1\end{array}$

As características pessoais e laborais dos dirigentes estão representadas por médio das variáveis incluídas no questionário de estilos de liderança (seção de dados pessoais), descritos no Apêndice A e mostrado no ponto 4.4.

\section{Tratamento estatístico dos dados}

Os conceitos do modelo da liderança situacional estão descritos pelas seguintes variáveis:

S: Os estilos de liderança: S1: o estilo instrutivo; S2: o estilo persuasivo; S3: o estilo participativo; S4: o estilo delegatorio

R: Os graus de maturidade dos seguidores: R1: grau de maturidade inativo; R1: grau de maturidade reativo; R1: grau de maturidade pró-ativo; R1: grau de maturidade interativo

C: O traço Tipo A dos dirigentes

As variáveis, acima descritas, se classificam em dependentes e independentes.

As variáveis dependentes se classificam em: S1, S2, S3 e S4.

As variáveis Independentes são: R1, R2, R3, R4 e C

Com estas variáveis se construíram quatro grupos de hipóteses. Cada grupo esta composto por quatro hipóteses, as quais são descritas no ponto 2.3. Cada grupo tem um modelo matemático geral, por exemplo, o descrito no ponto 4.1.1. No mesmo ponto (4.1.1), se descrevem os parâmetro do modelo matemático, geral, utilizados para a proposta das 
hipóteses nulas e alternas em cada grupo. Para a verificação das hipóteses se testaram as hipóteses nulas e as hipóteses alternativas em dois passos:

- Solução do modelo matemático para obter os parâmetros: se os parâmetros propostos fossem diferentes de zero - não se compre a hipótese nula $\left(\mathrm{H}_{\mathrm{o}}: \mathrm{Bi}=0\right)$.

- Aplicação da regra de decisão para recusar, ou não, a hipótese nula para o grupo um, dois, três e quatro, respectivamente, são descritos nos subitens 4.1.1; 4.1.2; 4.1.3 e 4.1.4.

Realizou-se um resumo dos cálculos matemáticos da verificação das hipóteses, os quais são apresentados graficamente no subitem 4.2

\subsection{Comprovação da hipótese}

A verificação das hipóteses formuladas foi realizada mediante o delineamento e aplicação de um modelo matemático geral para cada um dos quatro grupos de hipótese.

\subsubsection{Modelo matemático geral para as hipóteses do Grupo 1.}

O modelo matemático geral para relacionar os estilos de liderança com a maturidade dos seguidores e a conduta tipo A do líder foi:

$$
\begin{array}{ll}
5 & 5 \\
\mathrm{Si}=1 & \mathrm{f}(\mathrm{Ri}, \mathrm{C}) \\
\mathrm{i}=1
\end{array}
$$

Si - Representa os estilos de liderança (S1, S2, S3, S4) conforme o modelo de Hersey e Blanchard.

$R i$ - Representa os graus de maturidade (R1, R2, R3, R4) dos seguidores conforme o modelo de Hersey e Blanchard.

$C$ - Representa o traço Tipo A dos dirigentes.

Os parâmetros do modelo matemático geral para resolver as hipóteses do Grupo 1, foram os seguintes:

$$
\begin{aligned}
& 5 \\
& \mathrm{Si}=\beta \mathrm{o}+\beta_{1} \mathrm{R}_{1}+\beta_{2} \mathrm{R}_{2}+\beta_{3} \mathrm{R}_{3}+\beta_{4} \mathrm{R}_{4}+\beta_{5} \mathrm{C} \\
& i=1
\end{aligned}
$$




\section{Onde:}

Si - Representa os quatro estilos de liderança S1, S2, S3 e S4 conforme o modelo de Hersey e Blanchard.

$C$ - Representa as características de conduta tipo A das enfermeiras diretivas.

$\beta o$ - Representa a constante do modelo

$\beta(1-5)$ - Representa o coeficiente das variáveis independentes e parâmetros simultâneos para provar as hipóteses.

R1 a R4 - representam os graus de maturidade (habilidade e disposição) dos seguidores.

\section{Hipóteses estatísticas do grupo 1}

Com os parâmetros do modelo matemático se formularam tanto a hipótese nula quanto a hipótese alternativa.

Hipótese nula (Ho): $\begin{aligned} & 5 \\ & \beta \mathrm{i}=0 \\ & \mathrm{i}=1\end{aligned}$

Enunciado: "Não há relação entre a maturidade dos seguidores e a conduta do líder e os estilos de liderança conforme o modelo de Hersey e Blanchard".

Hipótese alternativa (Ha): $\quad \beta_{1} \neq 0$, ó, $\beta_{2} \neq 0$, ó, $\beta_{3} \neq 0$, ó, $\beta_{4} \neq 0$, ó, $\beta_{5} \neq 0$.

Enunciado: "Há relação entre a maturidade dos seguidores e a conduta do líder e os estilos de liderança conforme o modelo de Hersey e Blanchard".

Trata-se de provar a hipótese nula (Ho): $\beta_{1}=\beta_{2}=\beta_{3}=\beta_{4}=\beta_{5}=\mathbf{0}$, contra a hipótese alternativa (Ha): $\boldsymbol{\beta}_{1} \neq \mathbf{0}$, ó, $\boldsymbol{\beta}_{2} \neq \mathbf{0}$, ó, $\boldsymbol{\beta}_{3} \neq \mathbf{0}$, ó, $\boldsymbol{\beta}_{\mathbf{4}} \neq \mathbf{0}, \mathbf{o}, \beta_{5} \neq \mathbf{0}$.

Solução do modelo matemático para o estilo de liderança S1

Mediante a análise de regressão múltipla se obtiveram os coeficientes do modelo de

correlação de S1 com Ri e C, como indicado a continuação:

$$
\mathrm{S} 1=-0,09+0,47 \mathrm{R}_{1}+0,15 \mathrm{R}_{2}+0,55 \mathrm{R}_{3}+0,50 \mathrm{R}_{4}-0,04 \mathrm{C}
$$


Todos os coeficientes (parâmetros do modelo) das variáveis explicativas são diferentes de zero, pelo qual não se cumpre a hipótese nula. Não obstante, para rejeitar a hipótese nula é necessário recorrer à regra de decisão mediante a determinação do valor calculado e o valor crítico da estatística F de Snedecor. O valor observado ${ }^{1}$ de $\mathrm{F}$ é 1,25 . O valor crítico $^{2}$ de $\mathrm{F}$ é 2,39 .

\section{Regra de decisão}

A regra de decisão ${ }^{3}$ diz que se o valor observado de $\mathrm{F}$ é maior que o valor crítico de $\mathrm{F}$, se rejeita a hipótese nula $\left(\mathrm{H}_{\mathrm{o}}\right)^{4}$.

O valor observado de F é 1,25 e o valor crítico de F é 2,39. Portanto, aplicando a regra de decisão, se rejeita a hipótese nula (Ho). Em outras palavras, a maturidade dos seguidores (R1, R2, R3 e R4) e as características de conduta tipo A do líder (C), não explicam o estilo de liderança S1: alta orientação às tarefas e baixa orientação às relações interpessoais. Esta hipótese com base os resultados de a regra de decisão é nula significa que não há correlação entre as variáveis (o estilo de liderança instrutivo com graus de maturidade inativo, reativo, pró-ativo, interativo e traços da conduta tipo A ).

\section{Solução do modelo matemático para o estilo de liderança S2}

\footnotetext{
${ }^{1}$ o valor calculado de $\mathrm{F}$ se obtém mediante a seguinte fórmula:

$\mathrm{F}=(\mathrm{SCR} / \mathrm{V} 1) /(\mathrm{SCE} / \mathrm{v} 2)=\mathrm{CMR} / \mathrm{CME}$

Onde:

$\mathrm{SCR}=\Sigma(\mathrm{Yc}-\mathrm{Yp})^{2}$

$\mathrm{SCE}=\Sigma(\mathrm{Y}-\mathrm{Yc})^{2}$

Yc: Y calculado; Yp: Y médio; Y: Y original.

V1:Número de parâmetros $\beta$ no modelo menos um.

V2:Número de observações (n) menos o número de parâmetros $\beta$ no modelo

Substituindo os valores na fórmula se obtém o valor calculado de $\mathrm{F}$.

$\mathrm{F}=(0,26 / 5) /(0,159 / 36)=0,005 / 0,004=1,25$

${ }^{2} \mathrm{O}$ valor crítico se obtém da tabela de distribuição $\mathrm{F}$ com base nos seguintes valores

$\mathrm{n}$ : Número de observações $(\mathrm{n}=42)$.

$\mathrm{V}_{1}=$ Número de parâmetros do modelo menos um $(6-1=5)$

$\mathrm{V}_{2}=$ Número de observações ou número de parâmetro do modelo matemático $(42-6=36)$

$\alpha=$ probabilidade aceita de cometer erro de tipo I, ao rejeitar a hipótese nula $(\alpha=0,05)$.

$\mathrm{F}(\mathrm{v} 1=5, \mathrm{v} 2=36, \alpha=0,05)=2,39$.

${ }^{3}$ Mendenhall, W. y Reinmuth, J. E. Estadística para Administración y Economía. California, USA: Wadsworth Internacional/Iberoamérica, 1981. P. 366.

${ }^{4}$ Ibid. P. 376.
} 
Mediante a análise de regressão múltipla se obtiveram os coeficientes do modelo de correlação de S2, assim descrito:

$$
S 2=-0,03-0,03 R_{1}+0,6 R_{2}+0,01 R_{3}-0,50 R_{4}+0,53 C
$$

Todos os coeficientes (parâmetros) das variáveis são diferentes de zero, portanto, não se cumpre a hipótese nula. Não obstante, para rejeitá-la é necessário recorrer à regra de decisão mediante a determinação do valor calculado e do valor crítico da estatística $F$ de Snedecor. O valor observado ${ }^{5}$ de F é 10,15 . O valor crítico ${ }^{6}$ de F é 2,39.

\section{Regra de decisão}

Seguindo a regra de decisão e sendo o valor observado de F:10,15 e o valor crítico de F: 2,39 se cumpre a regra de decisão e rejeitada a hipótese nula $\left(\mathrm{H}_{0}\right)$. Em outras palavras, a maturidade dos seguidores (R1, R2, R3 e R4) e as características de conduta tipo A do líder, sim explicam o estilo de liderança S2: alta orientação às tarefas e alta orientação às relações interpessoais. É uma hipótese alterna e há relação entre as variáveis (o estilo de liderança persuasivo com graus de maturidade inativo, reativo, pró ativo, interativo e traços da conduta tipo A ).

\section{Solução do modelo matemático para o estilo de liderança S3}

Mediante a análise de regressão múltipla se obtiveram os coeficientes do modelo de correlação de S3 como indicado a seguir:

$$
\mathrm{S} 3=-0,09+0,39 \mathrm{R}_{1}+0,31 \mathrm{R}_{2}+0,36 \mathrm{R}_{3}+0,64 \mathrm{R}_{4}-0,29 \mathrm{C}
$$

\footnotetext{
${ }^{5} \mathrm{O}$ valor calculado de $\mathrm{F}$ se obtém mediante a seguinte fórmula: $\mathrm{F}=(\mathrm{SCR} / \mathrm{V} 1) /(\mathrm{SCE} / \mathrm{v} 2)=\mathrm{CMR} / \mathrm{CME}$

Onde:

$\mathrm{SCR}=\Sigma(\mathrm{Yc}-\mathrm{Yp})^{2}$

$\mathrm{SCE}=\Sigma(\mathrm{Y}-\mathrm{Yc})^{2}$

Yc: Y calculado; Yc: Y médio; Y: Y original.

V1: Número de parâmetros $\beta$ no modelo menos um (6-1=5).

V2: Número de observações (n) menos o número de parâmetros $\beta$ no modelo (42-6=36).

Substituindo os valores na fórmula se obtém o valor calculado de $\mathrm{F}$.

$\mathrm{F}=(0,3 / 5) /(0,212 / 36)=0,06 / 0,006=10,15$

${ }^{6} \mathrm{O}$ valor crítico se obtém da tabela de distribuição $\mathrm{F}$ com base nos seguintes valores $\mathrm{F}(\mathrm{V} 1=5, \mathrm{~V} 2=36, \alpha=0,05)$

V1 y V1 vistos antes. $\alpha=$ probabilidade aceita de cometer erro de tipo I, ao rejeitar a hipótese nula $(\alpha=0,05)$. $\mathrm{F}(\mathrm{v} 1=5, \mathrm{v} 2=36, \alpha=0,05)=2,39$.
} 
Todos os coeficientes (parâmetros) das variáveis são diferentes de zero. Portanto não se cumpre a hipótese nula. Não obstante, para a rejeição se recorre à regra de decisão adotada. O valor observado ${ }^{7}$ de F é 2,7. O valor crítico $^{8}$ de F é 2,39.

\section{Regra de decisão}

Seguindo a regra de decisão, sendo o valor observado de F: 2,7 e o valor crítico de F: 2,39, rejeita-se a hipótese nula $\left(\mathrm{H}_{0}\right)$. Em outras palavras, a maturidade dos seguidores $\mathrm{R} 1, \mathrm{R} 2$, R3 e R4 e as características de conduta tipo A do líder, explicam o estilo de liderança S3: baixa orientação às tarefas e alta orientação às relações interpessoais. Esta hipótese é alterna há correlação entre as variáveis (o estilo de liderança participativo com graus de maturidade inativo, reativo, pró ativo, interativo e traços da conduta tipo A ).

\section{Solução do modelo matemático para o estilo de liderança S4}

Mediante a análise de regressão múltipla se obtiveram os coeficientes do modelo de correlação de S4 como se indica a continuação:

$$
\mathrm{S} 4=0,5-0,17 \mathrm{R}_{1}-0,31 \mathrm{R}_{2}-0,27 \mathrm{R}_{3}-0,07 \mathrm{R}_{4}-0,27 \mathrm{C}
$$

Todos os coeficientes (parâmetros) das variáveis são diferentes de zero. Portanto não se cumpre a hipótese nula. Não obstante, para rejeitá-la é necessário recorrer à regra de decisão adotada. O valor observado ${ }^{9}$ de $\mathrm{F}$ é 1,93 . O valor crítico ${ }^{10}$ de $\mathrm{F}$ é $2,39$.

\footnotetext{
${ }^{7}$ o valor calculado de $\mathrm{F}$ se obtém mediante a seguinte fórmula:

$\mathrm{F}=(\mathrm{SCR} / \mathrm{V} 1) /(\mathrm{SCE} / \mathrm{v} 2)=\mathrm{CMR} / \mathrm{CME}$

Onde:

$\mathrm{SCR}=\Sigma(\mathrm{Yc}-\mathrm{Yp})^{2}$

$\mathrm{SCE}=\Sigma(\mathrm{Y}-\mathrm{Yc})^{2}$

Yc: Y calculado; Yc: Y médio; Y: Y original.

V1: Número de parâmetros $\beta$ no modelo menos um.

V2: Número de observações (n) menos o número de parâmetros $\beta$ no modelo

Substituindo os valores na fórmula se obtém o valor calculado de $\mathrm{F}$.

$\mathrm{F}=(335,32 / 5) / 896,01 / 36)=67,06 / 24,89=2,7$

${ }^{8} \mathrm{O}$ valor crítico se obtém da tabela de distribuição $\mathrm{F}$ com base nos seguintes valores

$\mathrm{F}(\mathrm{v} 1=5, \mathrm{v} 2=36, \alpha=0,05)$

V1 y V2 vistos antes y $\alpha=$ probabilidade aceita de cometer erro de tipo I, ao rejeitar a hipótese nula $(\alpha=0,05)$.

$\mathrm{F}(\mathrm{v} 1=5, \mathrm{v} 2=36, \alpha=0,05)=2,39$.

${ }^{9} \mathrm{o}$ valor calculado de $\mathrm{F}$ se obtém mediante a seguinte fórmula:

$\mathrm{F}=(\mathrm{SCR} / \mathrm{V} 1) /(\mathrm{SCE} / \mathrm{v} 2)=\mathrm{CMR} / \mathrm{CME}$
} 


\section{Regra de decisão}

Seguindo a regra de decisão, sendo o valor observado de F: 1,93 e o valor crítico de F: 2,39, não se rejeita a hipótese nula $\left(\mathrm{H}_{0}\right)$. Em outras palavras, a maturidade dos seguidores $(\mathrm{R} 1$, R2, R3 e R4) e as características de conduta tipo A do líder, não explicam o estilo de liderança S4: baixa orientação às tarefas e baixa orientação às relações interpessoais. É uma hipótese nula não há correlação entre variáveis (o estilo de liderança delegatório com graus de maturidade inativo, reativo, pró ativo, interativo e traços da conduta tipo A ).

\subsubsection{Modelo matemático geral para as hipóteses do Grupo 2}

O modelo matemático geral para relacionar os estilos de liderança com a maturidade dos seguidores é o seguinte:

Onde:

$$
\begin{array}{ll}
4 & 4 \\
\mathrm{Si}=1 & \mathrm{f}(\mathrm{Ri}) \\
\mathrm{i}=1
\end{array}
$$

$\mathrm{Si}$ - Representa os quatro estilos (S1, S2, S3 e S4) de liderança conforme o modelo de Hersey e Blanchard.

$\mathrm{Ri}$ - Representa os quatro grados da maturidade (R1, R2, R3 e R4) dos seguidores conforme o modelo de Hersey e Blanchard (1988).

Os parâmetros do modelo matemático geral para formular as hipóteses do Grupo 2 são os seguintes:

$$
\mathrm{Si}=\beta \mathrm{o}+\beta_{1} \mathrm{R}_{1}+\beta_{2} \mathrm{R}_{2}+\beta_{3} \mathrm{R}_{3}+\beta_{4} \mathrm{R}_{4}
$$

Onde:

$\mathrm{SCR}=\Sigma(\mathrm{Yc}-\mathrm{Yp})^{2}$

$\mathrm{SCE}=\Sigma(\mathrm{Y}-\mathrm{Yc})^{2}$

Yc: Y calculado; Yc: Y médio; Y: Y original.

V1: Número de parâmetros $\beta$ no modelo menos um.

V2: Número de observações (n) menos o número de parâmetros $\beta$ no modelo

Substituindo os valores na fórmula se obtém o valor calculado de $\mathrm{F}$.

$\mathrm{F}=(284,62 / 5) /(1060,45 / 36)=56,93 / 29,46=1,93$

${ }^{10} \mathrm{O}$ valor crítico se obtém da tabela de distribuição $\mathrm{F}$ com base nos seguintes valores:

$\mathrm{F}(\mathrm{v} 1=5, \mathrm{v} 2=36, \alpha=0,05)$

V1 y V2 vistos antes e $\alpha=$ probabilidade aceita de cometer erro de tipo I, ao rejeitar a hipótese nula $(\alpha=0,05)$.

$\mathrm{F}(\mathrm{v} 1=5, \mathrm{v} 2=36, \alpha=0,05)=2,39$. 


\section{Onde:}

ßo - Representa a constante do modelo

$\beta_{1-4}$ - São os coeficientes das variáveis independentes e ao mesmo tempo os parâmetros para provar as hipóteses.

\section{Hipótese estatística geral para o Grupo 2}

$\begin{array}{ll}\text { Hipótese nula }\left(\mathrm{H}_{0}\right): & \begin{array}{l}4 \\ \beta \mathrm{i}=0\end{array} \\ \mathrm{i}=1\end{array}$

Enunciado: "Não há relação entre os estilos de liderança S1, S2, S3 e S4 e a maturidade dos seguidores R1, R2, R3 e R4 conforme o modelo de Hersey e Blanchard". Hipótese alternativa $\mathrm{H}_{\mathrm{a}}: \quad \beta_{1} \neq 0, \mathrm{o}, \beta_{2} \neq 0, \mathrm{o}, \beta_{3} \neq 0, \mathrm{o}, \beta_{4} \neq 0$.

Enunciado: "Há relação entre os estilos de liderança S1, S2, S3 e S4 e o grau de maturidade dos seguidores R1, R2, R3 e R4 conforme o modelo de Hersey e Blanchard (1988)".

\section{Prova de hipótese}

Trata-se de provar a hipótese nula $\left(\mathrm{H}_{\mathrm{o}}\right)$ : $\beta_{1}=\beta_{2}=\beta_{3}=\beta_{4}=\mathbf{0}$, contra a hipótese alternativa $\left(\mathrm{H}_{\mathrm{a}}\right): \beta_{1} \neq \mathbf{0}, \mathbf{o}, \beta_{2} \neq \mathbf{0}, \mathbf{o}, \beta_{3} \neq \mathbf{0}, \mathbf{o}, \beta_{4} \neq \mathbf{0}$.

\section{Solução do modelo matemático para o estilo de liderança S1}

Mediante a análise de regressão múltipla se obteve os coeficientes do modelo de correlação de S1 como indicado a continuação:

$$
S 1=-0,12+0,47 R_{1}+0,14 R_{2}+0,56 R_{3}+0,5 R_{4} .
$$

Todos os coeficientes das variáveis (parâmetros do modelo) são diferentes de zero. Portanto não se cumpre a hipótese nula. Não obstante, para rejeitá-la é necessário recorrer à regra de decisão adotada. O valor observado ${ }^{11}$ de $\mathrm{F}$ é 1,15 . O valor crítico ${ }^{12}$ de $\mathrm{F}$ é 2,6.

\footnotetext{
${ }^{11}$ o valor calculado de F se obtém mediante a seguinte fórmula:
} 


\section{Regra de decisão}

Seguindo a regra de decisão, sendo o valor observado de F: 1,15 e o valor crítico de F: 2,696, não rejeita-se a hipótese nula $\left(\mathrm{H}_{0}\right)$. Em outras palavras, a maturidade dos seguidores (R1, R2, R3 e R4) não explica o estilo de liderança S1: alta orientação às tarefas e baixa orientação às relações interpessoais. É uma hipótese nula não há correlação entre variáveis (graus de maturidade inativo, reativo, pró-ativo e interativo com o estilo de liderança instrutivo).

\section{Solução do modelo matemático para o estilo de liderança S2}

Mediante a análise de regressão múltipla se obtiveram os coeficientes do modelo de correlação de S2 como se indica a continuação:

$$
\mathrm{S} 2=+0,41+0,004 \mathrm{R}_{1}+0,77 \mathrm{R}_{2}-0,14 \mathrm{R}_{3}-0,45 \mathrm{R}_{4}
$$

Todos os coeficientes (parâmetros) das variáveis são diferentes de zero. Portanto não se cumpre a hipótese nula. Não obstante, para rejeitá-la é necessário recorrer à regra de decisão adotada. O valor observado ${ }^{13}$ de $\mathrm{F}$ é 9,7 . O valor crítico ${ }^{14}$ de F é 2,634.

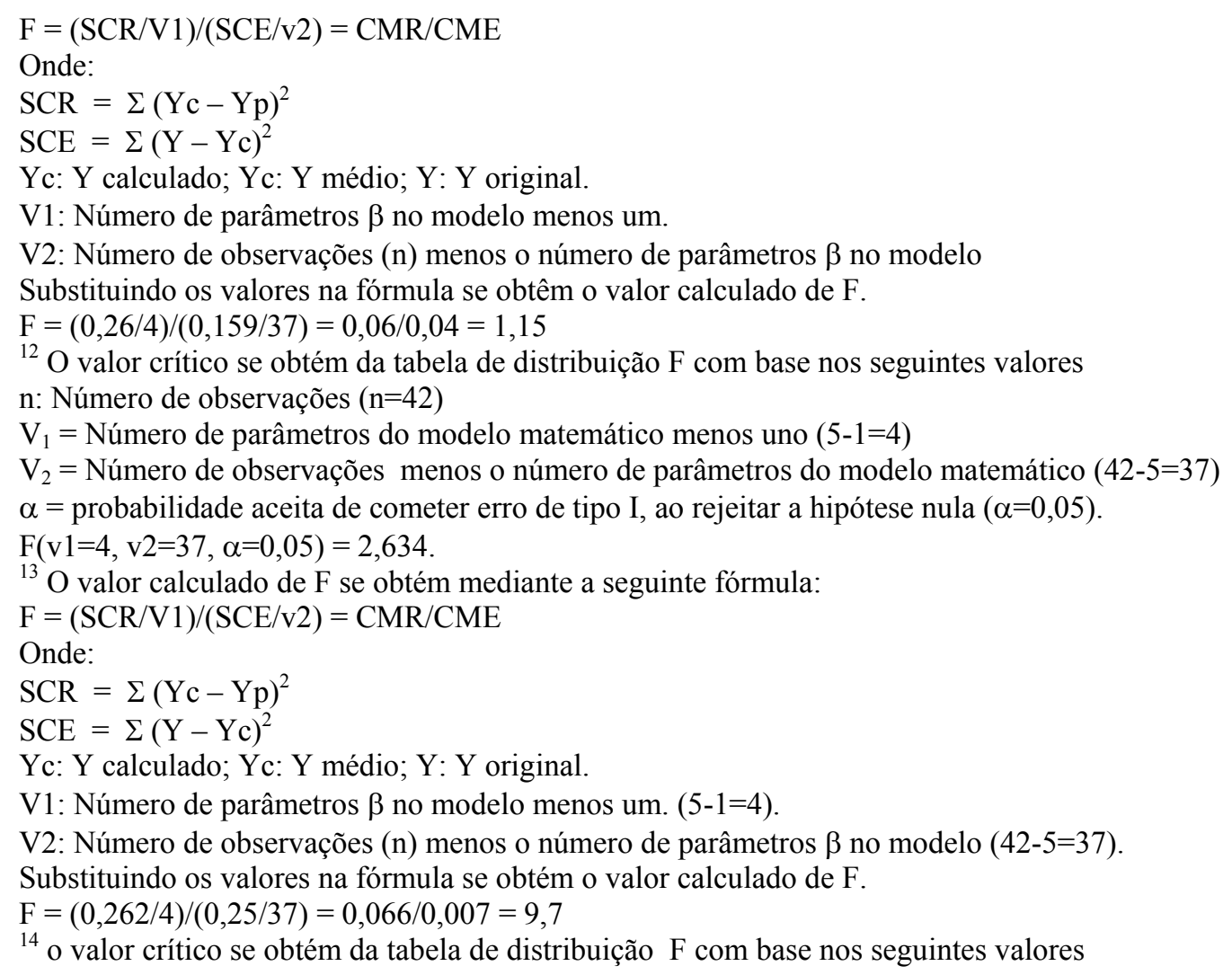




\section{Regra de decisão}

Seguindo a regra de decisão, sendo o valor observado de F: 9,7 e o valor crítico de F: 2,6, se rejeita a hipótese nula $\left(\mathrm{H}_{0}\right)$. Em outras palavras, a maturidade dos seguidores $(\mathrm{R} 1, \mathrm{R} 2$, R3 e R4) sim explicam o estilo de liderança S2 (alta orientação às tarefas e alta orientação às relações interpessoais). É uma hipótese alterna há correlação entre as variáveis (graus de maturidade inativo, reativo, pró-ativo e interativo com o estilo de liderança persuasivo).

\section{Solução do modelo matemático para o estilo de liderança S3}

Mediante a análise de regressão múltipla se obtiveram os coeficientes do modelo de correlação de S3 como se indica a continuação:

$$
\mathrm{S} 3=-0,29+0,41 \mathrm{R}_{1}+0,21 \mathrm{R}_{2}+0,44 \mathrm{R}_{3}+0,62 \mathrm{R}_{4}
$$

Todos os coeficientes (parâmetros) das variáveis são diferentes de zero. Portanto não se cumpre a hipótese nula. Não obstante, para rejeitá-la é necessário recorrer à regra de decisão adotada. $\mathrm{O}$ valor observado ${ }^{15}$ de $\mathrm{F}$ é 2,05. O valor crítico ${ }^{16}$ de $\mathrm{F}$ é 2,63.

\section{Regra de decisão}

Seguindo a regra de decisão e sendo o valor observado de F maior que o valor crítico de $\mathrm{F}$, se rejeita a hipótese nula $\left(\mathrm{H}_{0}\right)^{17}$. O valor observado de $\mathrm{F}$ é 2,05 e o valor crítico de $\mathrm{F}$ é

\footnotetext{
V1 y V2 vistos antes y, $\alpha=$ probabilidade aceitada de cometer erro de tipo I, ao rejeitar a hipótese nula $(\alpha=0,05)$. $\mathrm{F}(\mathrm{v} 1=4, \mathrm{v} 2=37, \alpha=0,05)=2,634$.

${ }^{15} \mathrm{O}$ valor calculado de $\mathrm{F}$ se obtém mediante a seguinte fórmula:

$\mathrm{F}=(\mathrm{SCR} / \mathrm{V} 1) /(\mathrm{SCE} / \mathrm{v} 2)=\mathrm{CMR} / \mathrm{CME}$

Onde:

$\mathrm{SCR}=\Sigma(\mathrm{Yc}-\mathrm{Yc})^{2}$

$\mathrm{SCE}=\Sigma(\mathrm{Y}-\mathrm{Yc})^{2}$

Yc: Y calculado; Yc: Y médio; Y: Y original.

V1: Número de parâmetros $\beta$ no modelo menos um.

V2: Número de observações (n) menos o número de parâmetros $\beta$ no modelo

Substituindo os valores na fórmula se obtém o valor calculado de $\mathrm{F}$.

$\mathrm{F}=(223,42 / 4) /(1007,91 / 37)=55,86 / 27.24=2,05$

${ }^{16} \mathrm{O}$ valor crítico se obtém da tabela de distribuição $\mathrm{F}$ com base nos seguintes valores

n: Número de observações $(n=42)$

$\mathrm{k}$ : Número de parâmetros $\beta$ no modelo $(\mathrm{k}=6)$

$\mathrm{V}_{1}=\mathrm{k}-1(5-1)=4 ; \mathrm{V}_{2}=\mathrm{n}-\mathrm{k}(42-5)=37$.

$\alpha=$ probabilidade aceita de cometer erro de tipo I, ao rejeitar a hipótese nula $(\alpha=0,05)$.

$\mathrm{F}(\mathrm{v} 1=5, \mathrm{v} 2=36, \alpha=0,05)=2,63$
} 
2,63. Portanto, aplicando a regra de decisão, não se rejeita a hipótese nula $\left(\mathrm{H}_{0}\right)$. Em outras palavras, a maturidade dos seguidores (R1, R2, R3 e R4) não explicam o estilo de liderança S3: baixa orientação às tarefas e alta orientação às relações interpessoais. É uma hipótese nula não há correlação entre variáveis (graus de maturidade inativo, reativo, pró-ativo e interativo com o estilo de liderança participativo).

\section{Solução do modelo matemático para o estilo de liderança S4}

Mediante a análise de regressão múltipla se obtiveram os coeficientes do modelo de correlação de S4 como se indica a continuação:

$$
\mathrm{S} 4=0,31-0,16 \mathrm{R}_{1}-0,39 \mathrm{R}_{2}-0,19 \mathrm{R}_{3}-0,09 \mathrm{R}_{4}
$$

Todos os coeficientes (parâmetros) das variáveis são diferentes de zero. Portanto não se cumpre a hipótese nula. Não obstante, para rejeitá-la é necessário recorrer à regra de decisão adotada. O valor observado ${ }^{18}$ de $\mathrm{F}$ é 1,52. O valor crítico ${ }^{19}$ de $\mathrm{F}$ é 2,63.

\section{Regra de decisão}

Seguindo a regra de decisão, sendo o valor observado de F:é 1,52 e o valor crítico de $F$ 2,63, portanto, aplicando a regra de decisão, não se rejeita a hipótese nula (Ho). Em outras

\footnotetext{
${ }^{17}$ Ibid. P. 376.

${ }^{18} \mathrm{O}$ valor calculado de $\mathrm{F}$ se obtém mediante a seguinte fórmula:

$\mathrm{F}=(\mathrm{SCR} / \mathrm{V} 1) /(\mathrm{SCE} / \mathrm{v} 2)=\mathrm{CMR} / \mathrm{CME}$

Onde:

$\mathrm{SCR}=\Sigma(\mathrm{Yc}-\mathrm{Yp})^{2}$

$\mathrm{SCE}=\Sigma(\mathrm{Y}-\mathrm{Yc})^{2}$

Yc: Y calculado; Yc: Y médio; Y: Y original.

V1: Número de parâmetros $\beta$ no modelo menos um.

V2: Número de observações (n) menos o número de parâmetros $\beta$ no modelo

Substituindo os valores na fórmula se obtém o valor calculado de $\mathrm{F}$.

$\mathrm{F}=(189,28 / 4) /(1155,79 / 37)=47,32 / 31,24=1,52$

${ }^{19}$ o valor crítico se obtém da tabela de distribuição $\mathrm{F}$ com base nos seguintes valores

$\mathrm{n}$ : Número de observações $(\mathrm{n}=42)$

$\mathrm{k}$ : Número de parâmetros $\beta$ no modelo $(\mathrm{k}=5)$

$\mathrm{V}_{1}=\mathrm{k}-1(5-1)=4$

$\mathrm{V}_{2}=\mathrm{n}-\mathrm{k}(42-5)=37$

$\alpha=$ probabilidade aceita de cometer erro de tipo I, ao rejeitar a hipótese nula $(\alpha=0,05)$.

$\mathrm{F}(\mathrm{v} 1=5, \mathrm{v} 2=36, \alpha=0,05)=2,634$.
} 
palavras, os graus de maturidade dos seguidores R1, R2, R3 e R4 não explicam o estilo de liderança S4: baixa orientação às tarefas e baixa orientação às relações interpessoais. É uma hipótese nula não há correlação entre variáveis (graus de maturidade inativo, reativo, próativo e interativo com o estilo de liderança delegativo).

\subsubsection{Modelo matemático geral para as hipóteses do Grupo 3}

O modelo matemático geral para relacionar os estilos de liderança com a maturidade dos seguidores é o seguinte:

$$
\underset{i=1}{\mathrm{Si}=} \mathrm{f}(\mathrm{C})
$$

Onde:

$S i$ - São os quatro estilos de liderança conforme o modelo de Hersey e Blanchard (1988).

$C$-É o Traço Tipo A dos dirigentes, conforme Friedman e Rosenmann (1976).

O parâmetro para formular as hipóteses do Grupo 3 é o seguinte:

\section{Onde:}

$$
\mathrm{Si}=\beta \mathrm{o}+\beta_{1}(\mathrm{C})
$$

ßo - É a constante do modelo.

$\beta_{1} \quad$ Representa o parâmetro para a formulação de hipótese

\section{Hipótese estatística geral para o Grupo 3}

Hipótese nula (Ho): $\beta_{1}=0$

Enunciado: "Não há relação entre os estilos do líder S1, S2, S3 e S4 e as características de conduta tipo A".

Hipótese alternativa Ha: $\beta_{1} \neq 0$.

Enunciado: "Há relação entre os estilos de liderança e as características de conduta tipo A".

\section{Prova de hipótese}

Trata-se de provar a hipótese nula (Ho): $\boldsymbol{\beta}_{\mathbf{1}}=\mathbf{0}$, contra a hipótese alternativa $(\mathrm{Ha}): \boldsymbol{\beta}_{\mathbf{1}} \neq \mathbf{0}$. 


\section{Solução do modelo matemático para o estilo de liderança S1}

Mediante a análise de regressão linear se obteve o coeficiente do modelo de correlação de S1:

$$
\mathrm{S} 1=0,43-0,2 \mathrm{C} .
$$

O coeficiente (parâmetro) da variável é diferente de zero, portanto não se cumpre a hipótese nula. Não obstante, para rejeitá-la é necessário recorrer à regra de decisão adotada. $\mathrm{O}$ valor observado $^{20}$ de F é 1,6. O valor crítico $^{21}$ de F é 4,08.

\section{Regra de decisão}

Seguindo a regra de decisão, sendo o valor observado de F: 1,6 e o valor crítico de F: 4,08, não se rejeita a hipótese nula (Ho). Em outras palavras, as características da conduta tipo A das enfermeiras que exercem cargos de direção, não explica o estilo de liderança S1: alta orientação às tarefas e baixa orientação às relações interpessoais. É uma hipótese nula não há correlação entre variáveis (o estilo de liderança instrutivo entre os traços de conduta tipo A).

\section{Solução do modelo matemático para o estilo de liderança S2}

Mediante a análise de regressão linear se obteve o coeficiente do modelo de correlação de S2:

$$
\mathrm{S} 2=-0,06+0,78 \mathrm{C}
$$

O coeficiente (parâmetro) da variável é diferente de zero, portanto não se cumpre a hipótese nula. Não obstante, para rejeitá-la é necessário recorrer à regra de decisão adotada. $\mathrm{O}$ valor observado $^{22}$ de F é 10,96. O valor crítico ${ }^{23}$ de F é 4,08.

\footnotetext{
${ }^{20} \mathrm{O}$ valor calculado de $\mathrm{F}=(\mathrm{SCR} / \mathrm{V} 1) /(\mathrm{SCE} / \mathrm{V} 2)=(0,007 / 1) /(0,177 / 40)=0,007 / 0,004=1,6$ Onde:

$\mathrm{SCR}=\Sigma(\mathrm{Yc}-\mathrm{Yp})^{2}$

$\mathrm{SCE}=\Sigma(\mathrm{Y}-\mathrm{Yc})^{2}$

Yc: Y calculado; Yc: Y médio; Y: Y original.

V1; Número de parâmetros $\beta$ no modelo menos um $(2-1=1)$.

V2: Número de observações (n) menos o número de parâmetros $\beta$ no modelo ( $42-2=40)$.

${ }^{21} \mathrm{O}$ valor crítico de $\mathrm{F}$ se obtém da tabela de distribuição com base nos seguintes valores

$\mathrm{V} 1=1 ; \mathrm{v} 2=40 ; \alpha=0,05$ $\mathrm{F}(1,40,0,05)=4,08$.

${ }_{22} \mathrm{O}$ valor calculado de $\mathrm{F}=(\mathrm{SCR} / \mathrm{V} 1) /(\mathrm{SCE} / \mathrm{V} 2)=(0,11 / 1) /(0,402 / 40)=0,11 / 0,01=10,96$ Onde:
} 


\section{Regra de decisão}

Seguindo a regra de decisão, sendo o valor observado de F: 10,96 e o valor crítico de F: 4,08 se rejeita a hipótese nula (Ho). Em outras palavras, as características da conduta tipo A das enfermeiras que exercem cargos de direção sim explicam o estilo de liderança S2: alta orientação às tarefas e alta orientação às relações interpessoais. É uma hipótese alterna há correlação entre variáveis (o estilo de liderança persuasivo com os traços de conduta tipo A).

\section{Solução do modelo matemático para o estilo de liderança S3}

Mediante a análise de regressão linear se obteve o coeficiente do modelo de correlação de S3:

$$
\mathrm{S} 3=0,32-0,29 \mathrm{C}
$$

O coeficiente (parâmetro) da variável é diferente de zero, portanto não se cumpre a hipótese nula. Não obstante, para rejeitá-la é necessário recorrer à regra de decisão adotada. O valor observado $^{24}$ de F é 5,59. O valor crítico ${ }^{25}$ de F é 4,08.

\section{Regra de decisão}

Seguindo a regra de decisão, sendo o valor observado de F 5,59 e o valor crítico de F 4,08 se rejeita a hipótese nula (Ho) se explicam que as características da conduta tipo A das enfermeiras que exercem cargos de direção sim explicam o estilo de liderança S3: baixa

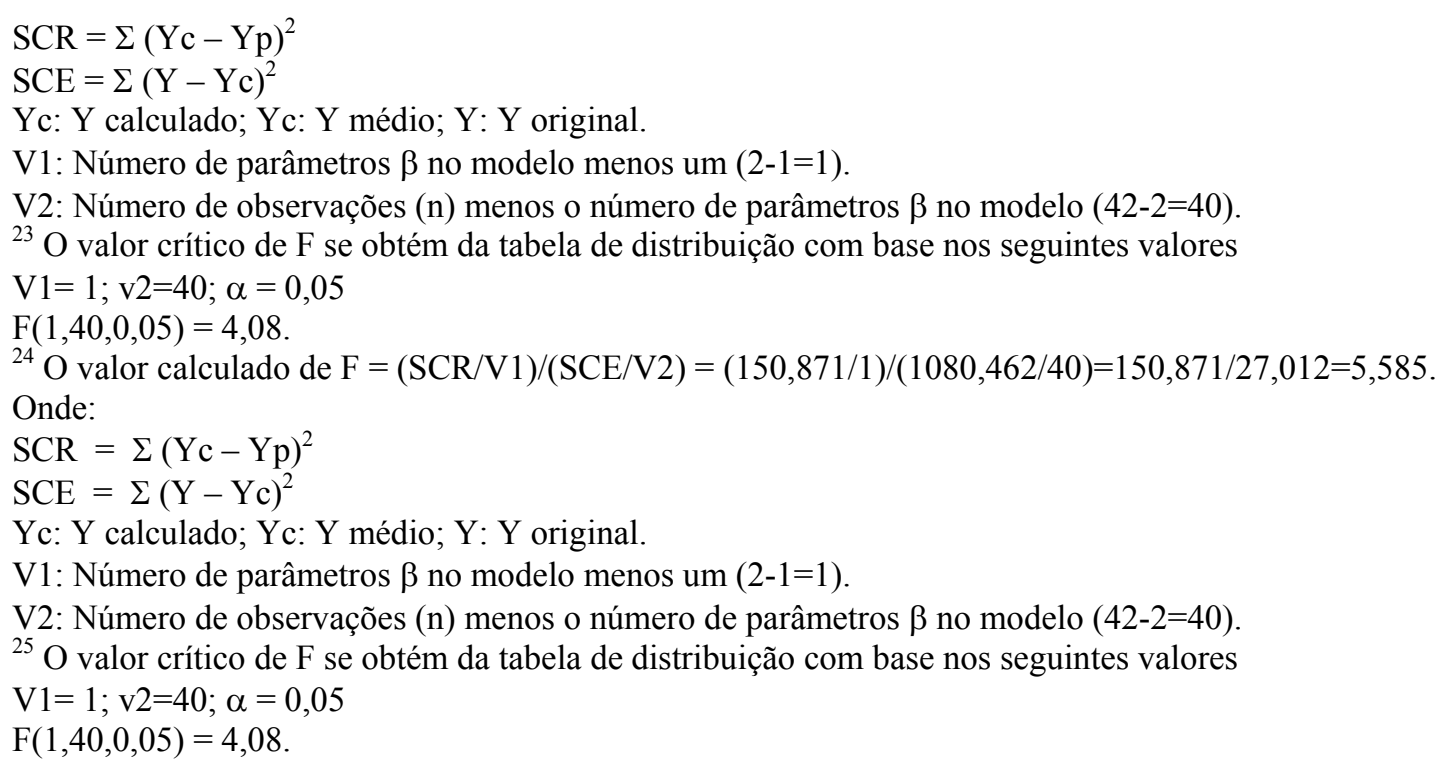


orientação às tarefas e alta orientação às relações interpessoais. É uma hipótese alterna há correlações entre variáveis (o estilo de liderança participativo com os traços de conduta tipo A).

\section{Solução do modelo matemático para o estilo de liderança S4}

Mediante a análise de regressão linear se obteve o coeficiente do modelo de correlação de S4:

$$
\mathrm{S} 4=0,31-0,29 \mathrm{C}
$$

O coeficiente (parâmetro) da variável é diferente de zero, portanto não se cumpre a hipótese nula. Não obstante, para rejeitá-la é necessário recorrer à regra de decisão adotada. $\mathrm{O}$ valor observado ${ }^{26}$ de F é 5,31. O valor crítico ${ }^{27}$ de F é 4,08.

\section{Regra de decisão}

Seguindo a regra de decisão, sendo o valor observado de F: 5,31 e o valor crítico de F: 4,08 , isto indica que a hipótese nula (Ho) deve ser rejeitada. Isto é, as características da conduta tipo A das enfermeiras que exercem cargos de direção explicam o estilo de liderança S4: baixa orientação às tarefas e baixa orientação às relações interpessoais. É uma hipótese alterna há correlações entre variáveis (o estilo de liderança delegativo com os traços de conduta tipo A).

\subsubsection{Modelo matemático geral para as hipóteses do Grupo 4}

O modelo geral para relacionar os estilos de liderança com a maturidade dos seguidores foi o seguinte:

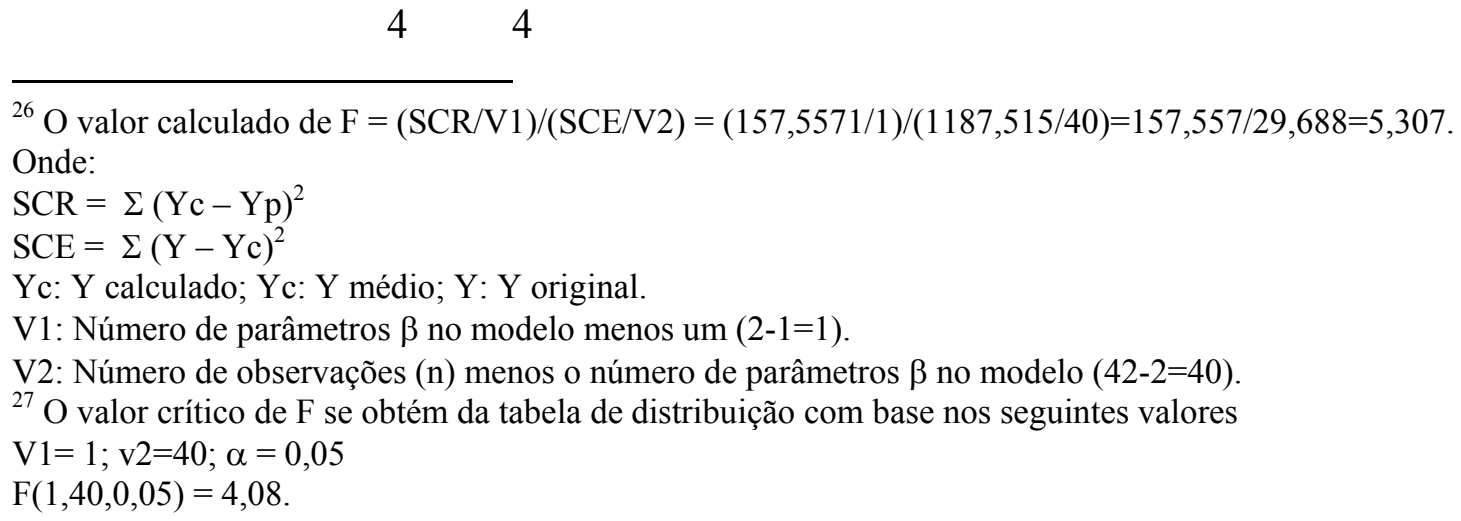


Onde:

$$
\begin{array}{ll}
\mathrm{Si}= & \mathrm{f}(\mathrm{Ri}) \\
\mathrm{i}=1 & \mathrm{i}=1
\end{array}
$$

Si - Representa os estilos (S1, S2, S3 e S4) de liderança conforme o modelo de Hersey e Blanchard.

$R i$ - Representa os graus de maturidade (R1, R2, R3 e R4) dos seguidores conforme o modelo de Hersey e Blanchard.

Os parâmetros do modelo matemático geral do Grupo 4, para a formulação de hipótese são os seguintes:

\section{Onde:}

$$
\begin{aligned}
& 44 \\
& \mathrm{Si}=\quad \beta o+\beta_{1}(\mathrm{Ri}) \\
& \mathbf{i}=1 \quad \mathbf{i}=1
\end{aligned}
$$

ßo - Representa constante do modelo.

$\beta_{1-4}-$ Representa os parâmetros para formulação de hipótese.

\section{Hipóteses estatísticas gerais para o Grupo 4}

Hipótese nula (Ho): $\beta_{1-4}=0$, "Não há relação entre os estilos do líder (S1, S2, S3 e S4) e os graus de maturidade R1, R2, R3 e R4 dos seguidores conforme o modelo de Hersey e Blanchard".

Hipótese alternativa Ha: $\beta_{1-4} \neq 0$, “Há relação entre os estilos de liderança S1, S2, S3 e S4 e os graus de maturidade R1, R2, R3 e R4 dos seguidores conforme o modelo de Hersey e Blanchard".

\section{Solução do modelo matemático para o estilo de liderança S1}

Mediante a análise de regressão linear se obteve o coeficiente do modelo de correlação de S1:

$$
\mathrm{S} 1=0,27+0,03 \mathrm{R} 1
$$


O coeficiente (parâmetro) da variável é diferente de zero, portanto não se cumpre a hipótese nula. Não obstante, para rejeitá-la é necessário recorrer à regra de decisão adotada. $\mathrm{O}$ valor observado $^{28}$ de F é 0,09 . O valor crítico ${ }^{29}$ de F é 4,08.

\section{Regra de decisão}

Seguindo a regra de decisão, sendo o valor observado de F 0,09 e o valor crítico de F 4,08 não se rejeita a hipótese nula (Ho), indicando que, os seguidores R1 que apresentam alto grau de habilidade e baixo grau de disposição ao cumprimento das tarefas não influem no estilo de liderança S1 caracterizado por sua alta tendência às tarefas e baixa tendência às relações interpessoais. É uma hipótese nula não há correlações entre variáveis (estilo de liderança instrutivo com grau de maturidade inativo).

\section{Solução do modelo matemático para o estilo de liderança S2}

Mediante a análise de regressão linear se obteve o coeficiente do modelo de correlação de S2:

$$
\mathrm{S} 2=0,22+0,98 \mathrm{R} 2
$$

Considerando-se os parâmetros predeterminados para a tomada de decisão de rejeitar a hipótese nula seria determinado pelo valor calculado e o valor crítico da estatística $\mathrm{F}$ de Snedecor. Assim, o valor observado ${ }^{30}$ de F 29,33 e o valor crítico ${ }^{31}$ de F 4,08.

\footnotetext{
${ }^{28} \mathrm{O}$ valor calculado de $\mathrm{F}=(\mathrm{SCR} / \mathrm{V} 1) /(\mathrm{SCE} / \mathrm{V} 2)=(0,00044 / 1) /(0,184 / 40)=0,00044 / 0,005=0,088$ Onde:

$\mathrm{SCR}=\Sigma(\mathrm{Yc}-\mathrm{Yp})^{2}$

$\mathrm{SCE}=\Sigma(\mathrm{Y}-\mathrm{Yc})^{2}$

Yc: Y calculado; Yc: Y médio; Y: Y original.

V1: Número de parâmetros $\beta$ no modelo menos um $(2-1=1)$.

V2: Número de observações (n) menos o número de parâmetros $\beta$ no modelo $(42-2=40)$.

${ }^{29} \mathrm{O}$ valor crítico de $\mathrm{F}$ se obtém da tabela de distribuição com base nos seguintes valores

$\mathrm{V} 1=1 ; \mathrm{v} 2=40 ; \alpha=0,05$

$\mathrm{F}(1,40,0,05)=4,08$.

${ }^{30} \mathrm{O}$ valor calculado de $\mathrm{F}=(\mathrm{SCR} / \mathrm{V} 1) /(\mathrm{SCE} / \mathrm{V} 2)=(0,217 / 1) /(0,295 / 40)=0,217 / 0,007=29,33$

Onde:

$\mathrm{SCR}=\Sigma(\mathrm{Yc}-\mathrm{Yc})^{2}$

$\mathrm{SCE}=\Sigma(\mathrm{Y}-\mathrm{Yc})^{2}$

Yc: Y calculado; Yc: Y médio; Y: Y original.

V1: Número de parâmetros $\beta$ no modelo menos um (2-1=1).

V2: Número de observações (n) menos o número de parâmetros $\beta$ no modelo $(42-2=40)$.
} 


\section{Regra de decisão}

Seguindo a regra de decisão, sendo o valor observado de F: 29,33 e o valor crítico de F: 4,08, se rejeita a hipótese nula (Ho). Isto é, na população analisada, os seguidores R2 que apresentam alto grau de habilidade e alta disposição ao cumprimento das tarefas sim influem no estilo de liderança S2 caracterizado por sua alta tendência às tarefas e alta tendência às relações interpessoais. É uma hipótese alterna há correlações entre variáveis (estilo de liderança persuasivo com grau de maturidade reativo).

\section{Solução do modelo matemático para o estilo de liderança S3}

Mediante a análise de regressão linear se obteve o coeficiente do modelo de correlação de S3:

$$
\mathrm{S} 3=0,1+0,02(\mathrm{R} 3)
$$

Considerando-se os parâmetros predeterminados para a tomada de decisão, de rejeição da hipótese nula, esta seria determinada pelo valor calculado e o valor crítico da estatística $\mathrm{F}$ de Snedecor. Assim sendo, o valor observado ${ }^{32}$ de F 0,04 e o valor crítico $^{33}$ de F 4,08.

\section{Regra de decisão}

Seguindo a regra de decisão ${ }^{34}$, e sendo o valor observado de F: 0,04 e o valor crítico de F: 4,08, não se rejeita a hipótese nula (Ho). Em outras palavras, na população analisada, os

\footnotetext{
${ }^{31} \mathrm{O}$ valor crítico de $\mathrm{F}$ se obtém da tabela de distribuição com base nos seguintes valores $\mathrm{V} 1=1 ; \mathrm{v} 2=40 ; \alpha=0,05$ 
seguidores R3 que apresentam baixa habilidade e alta disposição ao cumprimento das tarefas não influem no estilo de liderança S3 caracterizado por sua baixa tendência às tarefas e alta tendência às relações interpessoais. É uma hipótese nula não há correlações entre variáveis (estilo de liderança participativo com grau de maturidade pró-ativo).

\section{Solução do modelo matemático para o estilo de liderança S4}

Mediante a análise de regressão linear se obteve o coeficiente do modelo de correlação de S4:

$$
\mathrm{S} 4=0,05+0,17(\mathrm{R} 4)
$$

Considerando-se os parâmetros predeterminados para a tomada de decisão, de rejeitar a hipótese nula, esta seria determinada pelo valor calculado e o valor crítico da estatística $\mathrm{F}$ de Snedecor. Assim sendo, o valor observado ${ }^{35}$ de F 2,27 e o valor crítico ${ }^{36}$ de F 4,08.

\section{Regra de decisão}

Seguindo a regra de decisão, sendo o valor observado de F: 2,27 e o valor crítico de F: 4,08, não se rejeita a hipótese nula (Ho). Isto indica que, na população analisada, os seguidores R4 que apresentam baixa habilidade e baixa disposição para o cumprimento das tarefas não influem no estilo de liderança S4 caracterizado por sua baixa tendência às tarefas e baixa tendência às relações interpessoais. É uma hipótese nula não há correlações entre variáveis (o estilo de liderança delegatório com grau de maturidade interativo).

\subsection{Resume de verificação das hipóteses}

\footnotetext{
${ }^{34}$ Ibidem P. 364.

${ }^{35} \mathrm{O}$ valor calculado de $\mathrm{F}=(\mathrm{SCR} / \mathrm{V} 1) /(\mathrm{SCE} / \mathrm{V} 2)=(0,007 / 1) /(0,127 / 40)=0,003 /=2,27$

Onde:

$\mathrm{SCR}=\Sigma(\mathrm{Yc}-\mathrm{Yp})^{2}$

$\mathrm{SCE}=\Sigma(\mathrm{Y}-\mathrm{Yc})^{2}$

Yc: Y calculado; Yc: Y médio; Y: Y original.

V1: Número de parâmetros $\beta$ no modelo menos um $(2-1=1)$.

V2: Número de observações (n) menos o número de parâmetros $\beta$ no modelo (42-2=40).

${ }^{36} \mathrm{O}$ valor crítico de $\mathrm{F}$ se obtém da tabela de distribuição com base nos seguintes valores

$\mathrm{V} 1=1 ; \mathrm{v} 2=40 ; \alpha=0,05$

$\mathrm{F}(1,40,0,05)=4,08$.
} 
Nas seguintes figuras se mostra os resultados da solução dos modelos matemáticos de cada uma das hipóteses nos quatro grupos, acima citados.

$\mathrm{Na}$ figura 4 observa-se que o único estilo de liderança explicado por médio de coeficiente de determinação significativo, foi o persuasivo (S2).

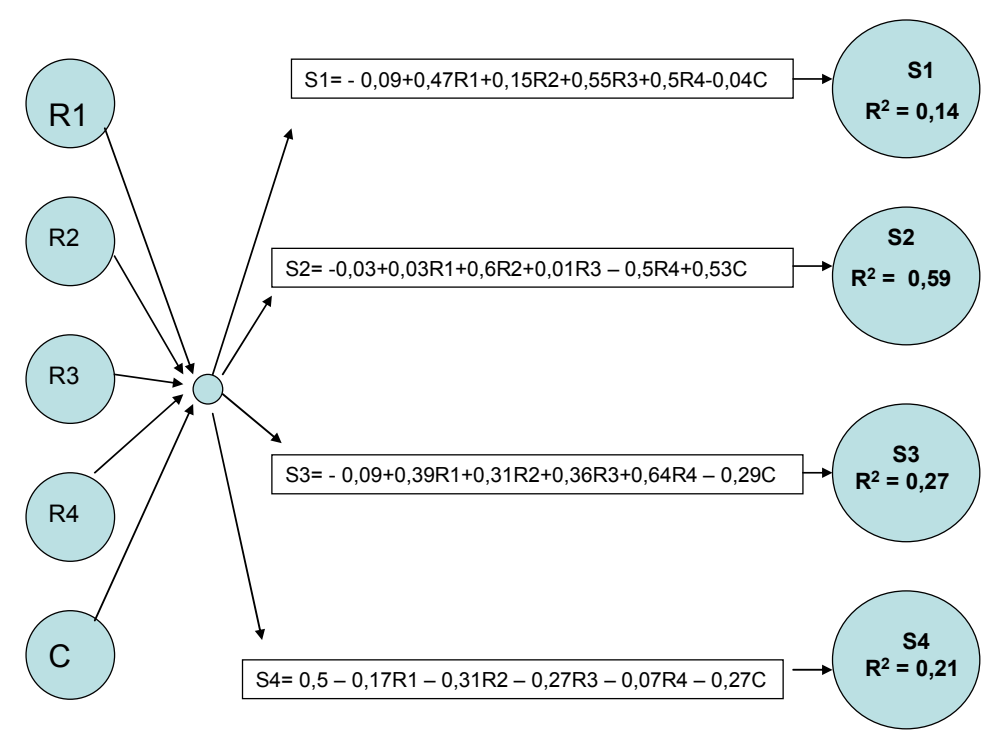

Figura 4 - Resultados verificação de hipóteses do Grupo 1

As dirigentes com estilo de liderança S2 têm como característica uma alta orientação às tarefas e alta orientação às relações. Hersey e Blanchard (1987) referem que o estilo persuasivo (S2) é indicado para seguidores que não têm capacidade, mas sentem disposição para assumir responsabilidades. Sua maturidade pode ser classificada entre baixa e moderada (R2). Os gerentes de enfermagem, com este estilo, oferecem um estilo dirigente (persuasivo) devido à falta de capacidade, no entanto, oferecem apoio para reforçar a disposição e o entusiasmo dos seus seguidores. Para tanto, definem o desenvolvimento dos papéis e tarefas dos profissionais de enfermeiras, tendo como base de apoio os protocolos, as regras entre outros. Ademais consideram importante a opinião, idéias e sugestões dos seguidores, ou seja, dos profissionais de enfermagem sob sua responsabilidade. 
As decisões são fatos inerentes do líder, mas, a comunicação é um atributo que facilita o relacionamento entre os diferentes cargos e/ou hierarquias. Os seguidores precisam de explicações para realizar o trabalho, já, o líder precisa procurar estratégias para estimular seus seguidores e contribuir com o aumento da auto-estima deles. O líder procura conseguir que o seguidor acredite e adote os comportamentos desejados. Galvão (1995) encontrou o estilo de liderança persuasivo, entre um grupo de enfermeiros e auxiliares de enfermagem de um hospital escola. Seguidos dos estilos: instrutivo, participativo e delegativo.

Na Figura 5, observa-se o estilo de liderança persuasivo (S2) e o grau de maturidade reativo (R2) como a única relação explicada de maneira significativa.

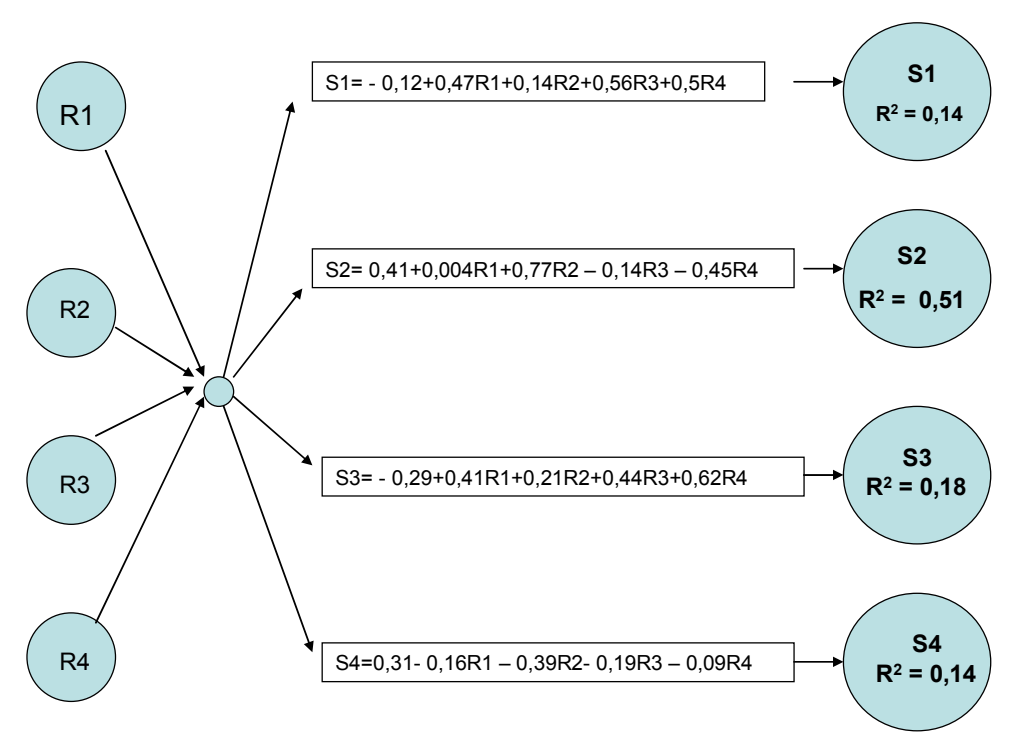

Figura 5 - Resultados de verificação de hipóteses do Grupo 2.

Desta combinação, de líderes e seguidores, se infere que o líder, por suas características, tem que trabalhar acreditando em suas decisões visando a motivar seus seguidores que apresentam uma baixa disposição e alta habilidade.

Na Figura 6 observa-se os resultados da correlação dos estilos de liderança com as características de traços de conduta tipo A, é possível apreciar que nenhum dos estilos de 
liderança foram explicados, significativamente, pelos traços de conduta tipo A. As relações de S1, S2, S3 e S4 com C não são satisfatórias.

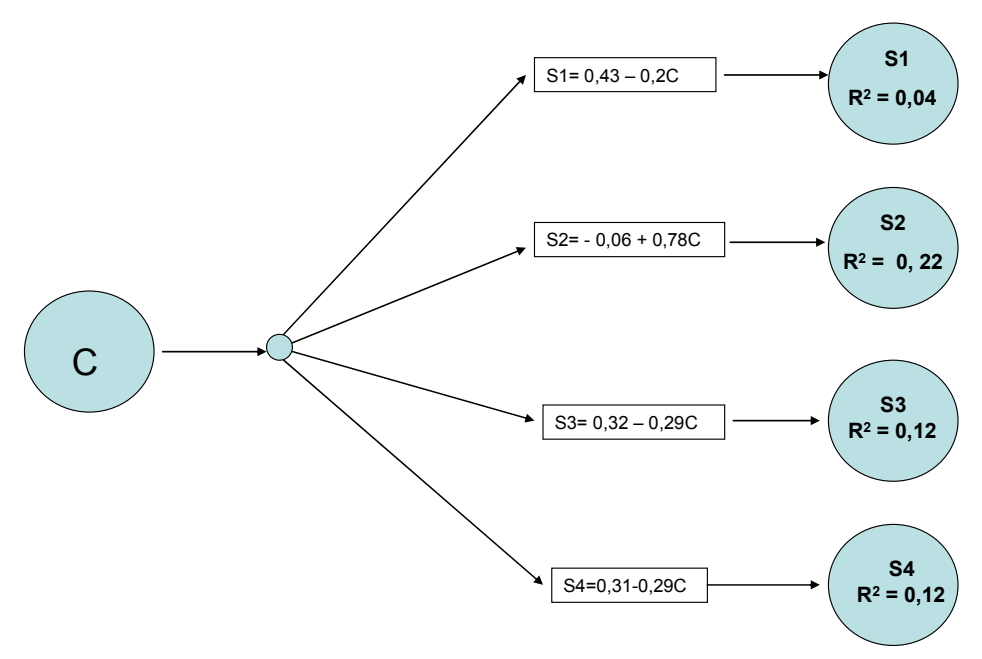

Figura 6 -. Resultados de verificação de hipóteses do Grupo 3

Os resultados mostram rações variadas que poderia estar relacionada com o tipo de entrevista utilizada (estruturada) que, pela sua natureza, apresentam limitações, no estudo de fenômenos sociais, pela complexa quantificação dos dados.

Com o propósito de ter maior certeza, em os resultados analisados se passou a procura de uma relação pareada entre estilos e graus de maturidade S1 com R1, S2 com R2, S3 com R3 e S4 com R4

Na Figura 7 se observa que a força de associação entre R2 e S2 é alta (R2: 0.98) e explica $63 \%$ das variações do estilo persuasivo (S2). A relação S4 e R4 é baixa, e as demais insignificantes. 


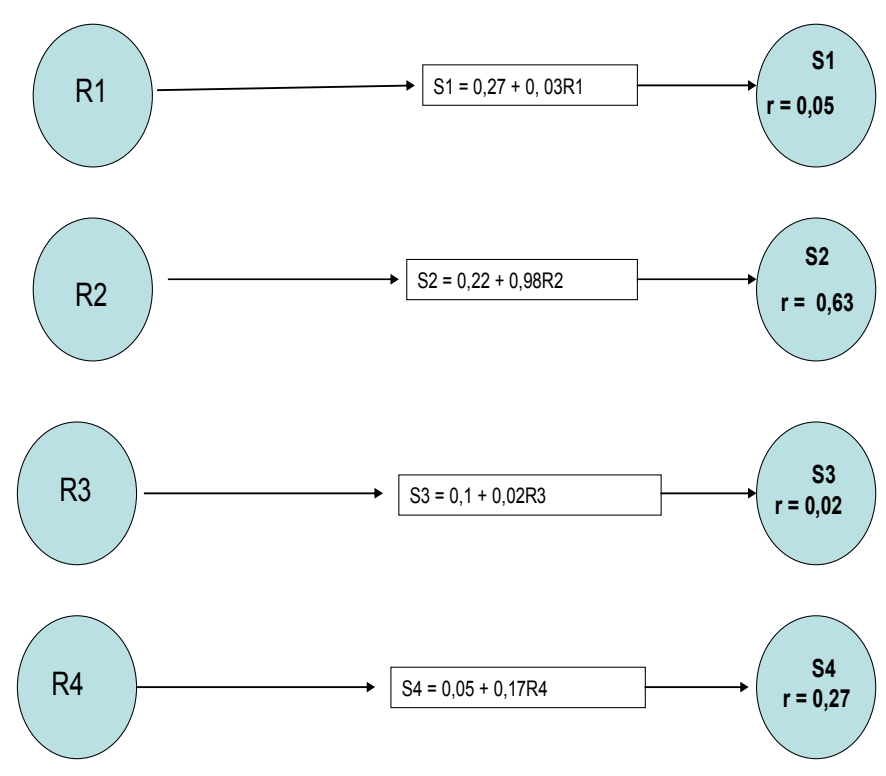

Figura 7. - Resultados de verificação de hipóteses do Grupo 4

Os resultados confirmam uma situação de diagnóstico da liderança de enfermagem, nos hospitais estudados, contemplados no referencial teórico do modelo de Hersey e Blanchard (1988). Para esta situação, os autores, propõem uma harmonizando entre um seguidor Reativo (R2) e o estilo Persuasivo (S2).

A proposta de harmonização visa a facilitar o diálogo e compreensão das ações do líder. A orientação às tarefas, por parte do líder, descreve o comportamento para a execução das tarefas (quê, como, quando, onde e quem?). O porquê, não está incluído, já que, este representa uma ponte entre o comportamento direcionado às tarefas e às relações. Em outras palavras, o estilo Persuasivo S2 inclui “explicação, persuasão e esclarecimento”.

Com base no Modelo Teórico de Hersey; Blanchard (1988), no Quadro 3, se apresenta uma harmonização entre um Estilo S2 e o grau de Maturidade R2

A seguir, apresentam-se, de maneira resumida, os resultados da verificação das hipóteses. 
Quadro 8 - Resultados da verificação das hipóteses

\begin{tabular}{|c|c|c|c|c|}
\hline Grupo & Hipótese & $\begin{array}{l}\mathrm{F} \\
\text { Observad } \\
\mathrm{o}\end{array}$ & $\begin{array}{l}\text { F } \\
\text { Critico }\end{array}$ & Se rejeita a hipótese nula \\
\hline \multirow[t]{4}{*}{ I } & $S 1=\beta o+\beta_{1} R_{1}+\beta_{2} R_{2}+\beta_{3} R_{3}+\beta_{4} R_{4}+\beta_{5} C$ & 1,25 & 2,39 & Não \\
\hline & $S 2=\beta o+\beta_{1} R_{1}+\beta_{2} R_{2}+\beta_{3} R_{3}+\beta_{4} R_{4}+\beta_{5} C$ & 10,15 & 2,39 & Sem \\
\hline & $\mathrm{S} 3=\beta \mathrm{o}+\beta_{1} \mathrm{R}_{1}+\beta_{2} \mathrm{R}_{2}+\beta_{3} \mathrm{R}_{3}+\beta_{4} \mathrm{R}_{4}+\beta_{5} \mathrm{C}$ & 2,7 & 2,39 & Sem \\
\hline & $\mathrm{S} 4=\beta \mathrm{o}+\beta_{1} \mathrm{R}_{1}+\beta_{2} \mathrm{R}_{2}+\beta_{3} \mathrm{R}_{3}+\beta_{4} \mathrm{R}_{4}+\beta_{5} \mathrm{C}$ & 1,93 & 2,39 & Não \\
\hline \multirow[t]{4}{*}{ II } & $\mathrm{S} 1=\beta \mathrm{o}+\beta_{1} \mathrm{R}_{1}+\beta_{2} \mathrm{R}_{2}+\beta_{3} \mathrm{R}_{3}+\beta_{4} \mathrm{R}_{4}$ & 1,15 & 2,60 & Não \\
\hline & $\mathrm{S} 2=\beta \mathrm{o}+\beta_{1} \mathrm{R}_{1}+\beta_{2} \mathrm{R}_{2}+\beta_{3} \mathrm{R}_{3}+\beta_{4} \mathrm{R}_{4}$ & 9,70 & 2,63 & Sem \\
\hline & $\mathrm{S} 3=\beta \mathrm{o}+\beta_{1} \mathrm{R}_{1}+\beta_{2} \mathrm{R}_{2}+\beta_{3} \mathrm{R}_{3}+\beta_{4} \mathrm{R}_{4}$ & 2,05 & 2,63 & Não \\
\hline & $\mathrm{S} 4=\beta \mathrm{o}+\beta_{1} \mathrm{R}_{1}+\beta_{2} \mathrm{R}_{2}+\beta_{3} \mathrm{R}_{3}+\beta_{4} \mathrm{R}_{4}$ & 1,52 & 2,63 & Não \\
\hline \multirow[t]{4}{*}{ III } & $\mathrm{S} 1=\beta \mathrm{o}+\beta_{1} \mathrm{C}$ & 1,60 & 4,08 & Não \\
\hline & $\mathrm{S} 2=\beta \mathrm{o}+\beta_{1} \mathrm{C}$ & 10,96 & 4,08 & Sem \\
\hline & $\mathrm{S} 3=\beta \mathrm{o}+\beta_{1} \mathrm{C}$ & 5,59 & 4,08 & Sem \\
\hline & $\mathrm{S} 4=\beta \mathrm{o}+\beta_{1} \mathrm{C}$ & 5,31 & 4,08 & Sem \\
\hline \multirow[t]{4}{*}{ IV } & $\mathrm{S} 1=\beta \mathrm{o}+\beta_{1} \mathrm{R}_{1}$ & 0,09 & 4,08 & Não \\
\hline & $\mathrm{S} 2=\beta \mathrm{o}+\beta_{1} \mathrm{R}_{2}$ & 29,33 & 4,08 & Sem \\
\hline & $\mathrm{S} 3=\beta \mathrm{o}+\beta_{1} \mathrm{R}_{3}$ & 0,04 & 4,08 & Não \\
\hline & $S 4=\beta \mathrm{o}+\beta_{1} R_{4}$ & 2.27 & 4,08 & Não \\
\hline
\end{tabular}

\subsection{Análise dos resultados das correlações verificadas dos estilos da liderança}

As correlações verificadas, entre o estilo de liderança, o grau de maturidade dos seguidores e o traço de conduta tipo A dos dirigentes, nos quatro grupos, apresentam-se no Quadro a seguir.

Quadro 9 - Hipóteses alternativas aceitas

\begin{tabular}{|c|c|c|c|c|}
\hline Grupo & Hipótese & $\begin{array}{l}\mathrm{F} \\
\text { Observado }\end{array}$ & $\begin{array}{l}\begin{array}{l}\text { F } \\
\text { critico }\end{array} \\
\end{array}$ & Observações \\
\hline \multirow[t]{2}{*}{ I } & $\mathrm{S} 2=\beta \mathrm{o}+\beta_{1} \mathrm{R}_{1}+\beta_{2} \mathrm{R}_{2}+\beta_{3} \mathrm{R}_{3}+\beta_{4} \mathrm{R}_{4}+\beta_{5} \mathrm{C}$ & 10,15 & 2,39 & \multirow{7}{*}{$\begin{array}{l}\text { Com base, na regra } \\
\text { da decisão, estas são } \\
\text { as correlações } \\
\text { verificadas, entre o } \\
\text { estilo de liderança, o } \\
\text { grau de maturidade } \\
\text { dos seguidores e o } \\
\text { traço de Conduta } \\
\text { Tipo A dos } \\
\text { dirigentes. }\end{array}$} \\
\hline & $\mathrm{S} 3=\beta \mathrm{o}+\beta_{1} \mathrm{R}_{1}+\beta_{2} \mathrm{R}_{2}+\beta_{3} \mathrm{R}_{3}+\beta_{4} \mathrm{R}_{4}+\beta_{5} \mathrm{C}$ & 2,70 & 2,39 & \\
\hline II & $\mathrm{S} 2=\beta \mathrm{o}+\beta_{1} \mathrm{R}_{1}+\beta_{2} \mathrm{R}_{2}+\beta_{3} \mathrm{R}_{3}+\beta_{4} \mathrm{R}_{4}$ & 9,70 & 2,63 & \\
\hline \multirow[t]{3}{*}{ III } & $\mathrm{S} 2=\beta \mathrm{o}+\beta_{1} \mathrm{C}$ & 10,96 & 4,08 & \\
\hline & $\mathrm{S} 3=\beta \mathrm{o}+\beta_{1} \mathrm{C}$ & 5,59 & 4,08 & \\
\hline & $\mathrm{S} 4=\beta \mathrm{o}+\beta_{1} \mathrm{C}$ & 5,31 & 4,08 & \\
\hline IV & $\mathrm{S} 2=\beta \mathrm{o}+\beta_{1} \mathrm{R}_{2}$ & 29,33 & 4,08 & \\
\hline
\end{tabular}


No grupo 1, se explicam os estilos de liderança S2 e S3 e R1, R2, R3, R4 e C; no grupo 2, se explica S2 e R1, R2, R3, R4; no grupo 3, se explicam S2, S3 e S4 e C e, no grupo 4, se explicam S2 com R2.

A seguir são analisadas essas relações, ou seja, a incidência dos graus de maturidade e o Traço de Conduta Tipo A dos dirigentes sobre os estilos de liderança.

Os coeficientes encontrados, das correlações nos quatro grupos de hipóteses, foram submetidos a uma valoração por meio de uma escala de ponderação dos coeficientes (Tabela 3). Isto permitiu conhecer o valor relativo da incidência de cada grupo de hipóteses com suas variáveis e classificações (baixa, mediana e alta correlação), apresentadas na tabela a seguir.

Tabela 3 - Escala de ponderação dos coeficientes.

\begin{tabular}{l|l|l}
\hline Limite inferior & Limite superior & Classificação \\
\hline 0,001 & 0,33 & Baixo \\
\hline 0,331 & 0,66 & Médio \\
\hline 0,661 & 1.00 & Alto \\
\hline
\end{tabular}

Este estilo se denomina "Persuasivo" por estar altamente orientado ao cumprimento das tarefas e altamente orientado às relações interpessoais.

\subsubsection{Explicações dos estilos de liderança do Grupo 1}

\section{Estilo de liderança persuasiva (S2).}

O resultado da correlação do estilo de liderança S2 com a maturidade (habilidade e disposição), dos seguidores cujos graus são R1 (inativo: baixa habilidade e baixa disposição), R2 (reativo: alta habilidade e baixa disposição), R3 (pró-ativo: baixa habilidade e alta disposição) e R4 (interativo: alta habilidade e alta disposição) e as características de conduta tipo A das enfermeiras com cargos dirigentes (C) foram analisados por meio da seguinte equação:

$$
\mathrm{S} 2=0,03+0,3 \mathrm{R} 1+0,6 \mathrm{R} 2+0,01 \mathrm{R} 3-0,5 \mathrm{R} 4+0,53 \mathrm{C}
$$


A correlação dos seguidores (inativos) cujo grau de maturidade é R1 (baixa competência e baixa disposição para as tarefas) sobre o estilo de liderança S2 (alta orientação às tarefas e alta orientação às relações interpessoais) é considerada baixa (R1 é 0,03), entre os seguidores (reativos) cujo grau de maturidade é R2 (alta habilidade e baixa disposição para as tarefas) sobre o estilo de liderança S2, foi media (R2 é 0,6), entre os seguidores (pró-ativos) cujo grau de maturidade é R3 (baixa habilidade e alta disposição para as tarefas) sobre o estilo de liderança S2 foi baixa (R3 é 0,01 ), entre os seguidores (interativos) cujo grau de maturidade é R4 (grande habilidade e boa disposição para as tarefas) sobre o estilo de liderança S2 foi negativa (R4 é -0,5) e entre as características de conduta tipo A dos dirigentes de enfermagem sobre o estilo de liderança S2 foi media (C é 0,53$)$.

Pode-se pensar que as variáveis influem no estilo de liderança S2, por tanto seus coeficientes som diferentes de zero. No obstante, a influência positiva, mais significativa é provindo das variáveis C e R2. A influência negativa da variável R4.

No presente estudo, o coeficiente de determinação $\left(\mathrm{R}^{2}=0,59\right)$ indica que o $59 \%$ das variáveis R1, R2, R3, R4 e C é relativamente alta. Em outras palavras, o ambiente e a maturidade dos seguidores favorecem a aparição do estilo de liderança persuasivo dos enfermeiros dirigentes dos hospitais da cidade de México.

\section{Estilo de liderança Participativo (S3)}

Este estilo se denomina "Participativo" por estar altamente orientado às relações interpessoais e pouco inclinado às tarefas. O resultado da correlação do estilo de liderança S3 (alta tendência às relações interpessoais e baixa tendência às tarefas) com a maturidade (habilidade e disposição) dos seguidores cujos graus são R1 (inativo), R2 (reativo), R3 (próativo) e R4 (interativo) e as características de conduta tipo A das enfermeiras com cargos dirigentes (C) é apresentada na seguinte equação.

$$
\mathrm{S} 3=-0,09+0,39 \mathrm{R} 1+0,31 \mathrm{R} 2+0,36 \mathrm{R} 3+0,64 \mathrm{R} 4-0,29 \mathrm{C}
$$


A correlação dos seguidores (inativos) cujo grau de maturidade é R1 (baixa competência e baixa disposição para as tarefas) sobre o estilo de liderança S3 (baixa orientação às tarefas e alta orientação às relações interpessoais) foi media (R1 é 0,39), entre os seguidores (reativos) cujo grau de maturidade é R2 (alta habilidade e baixa disposição para as tarefas) e o estilo de liderança S3 foi baixa (R2 é 0,31), para os seguidores (pró-ativos) cujo grau de maturidade é R3 (baixa habilidade e alta disposição para as tarefas) sobre o estilo de liderança S3 foi média (R3 é 0,36), entre os seguidores (interativos) cujo grau de maturidade é R4 (grande habilidade e boa disposição para as tarefas) e o estilo de liderança S3, é media (R4 é 0,64$)$ e entre as características de conduta tipo A das diretivas de enfermagem e o estilo de liderança S3 foi negativa (C é -0,29).

Todas as variáveis predictoras (R1, R2, R3, R4 e C) influem sobre o estilo de liderança S3, mas merece especial atenção a influencia que exerce a variável R4. Por tanto, os seguidores que mostram alta habilidade e boa disposição para o cumprimento das tarefas, geram um estilo de liderança S3 de seus chefes, isto é, estão bastante orientados às relações interpessoais e pouco à supervisão estrita das tarefas.

O estresse e traços de conduta Tipo A dos chefes são contraproducentes para o estilo de liderança S3.

O coeficiente de determinação $\left(\mathrm{R}^{2}=0,27\right)$ indica que somente o $27 \%$ das variações do estilo de liderança S3 é explicado pelas variáveis R1, R2, R3, R4 e C, indicado uma variação baixa. O restante (73\%) das variações de S2 está explicado por variáveis não identificadas, no presente estudo.

\subsubsection{Explicação dos resultados da análise de correlação do Grupo 2}

\section{Estilo de liderança Persuasivo (S2)}

Os resultados das correlações do estilo de liderança S2 com os graus de maturidade 
R1, R2, R3 e R4 foram obtidos por meio da seguinte equação.

$$
\mathrm{S} 2=0,41+0,004 \mathrm{R} 1+0,77 \mathrm{R} 2-0,14 \mathrm{R} 3-0,45 \mathrm{R} 4
$$

A correlação de R1 sobre S2 foi nula (R1: 0,00$)$, para R2 sobre S2 foi alta (R2: 0,77$)$, entre R3 e S2 foi negativa (R3:- 0,14$)$ e entre R4 e S2 foi negativa (R4: $-0,45)$.

O coeficiente de determinação $\left(\mathrm{R}^{2}=0,51\right)$ indica que $51 \%$ das variações do estilo de liderança S2 são explicadas pelas variáveis R1, R2, R3, R4, o que indica uma explicação de nível baixo. O restante 49\% das variações de S1 estariam sendo explicadas por variáveis não contempladas neste estudo.

\subsubsection{Explicação dos resultados da análise de correlação do Grupo 3}

\section{Estilo de liderança Persuasivo (S2)}

Os resultados da correlação do estilo de liderança S2 com as características dos traços de conduta tipo $\mathrm{A}(\mathrm{C})$ dos dirigentes de enfermagem foram obtidos com a seguinte equação.

$$
\mathrm{S} 2=0,06+0,78 \mathrm{C}
$$

Pode-se interpretar que a influência de $\mathrm{C}$ sobre S2 foi alta (C: 0,78$)$. O coeficiente de determinação $\left(\mathrm{R}^{2}=0,22\right)$ indica que o $22 \%$ das variações do estilo de liderança S2 são explicadas pela variável C. Isto é, a explicação é de nível baixo. O restante $78 \%$ das variações de S2 estaria sendo explicada por variáveis não contempladas no estudo.

\section{Estilo de liderança Participativo (S3)}

Os resultados da correlação do estilo de liderança S3 com as características dos traços de conduta tipo $\mathrm{A}(\mathrm{C})$ dos dirigentes de enfermagem foram obtidos com a seguinte equação:

$$
\mathrm{S} 3=0,32-0,29 \mathrm{C}
$$

A influência de $C$ sobre S3 é negativa (C: -0,29). O coeficiente de determinação $\left(R^{2}=\right.$ 0,12) indica que o $12 \%$ das variações do estilo de liderança S3 são explicadas pela variável C. Isto é, a explicação é de nível baixo. O restante $88 \%$ das variações de $\mathrm{S} 3$ estariam poderiam estar sendo explicadas por variáveis não contempladas neste estudo. 


\section{Estilo de liderança Delegativo (S4)}

Os resultados da correlação do estilo de liderança S4 com as características dos traços de conduta tipo A (C) dos diretivas de enfermagem foram obtidos com a seguinte equação:

$\mathrm{S} 4=0,31-0,29 \mathrm{C}$

Observa-se que a influência de C sobre S4 é negativa (C:- 0,29). O coeficiente de determinação $\left(\mathrm{R}^{2}=0,12\right)$ indica que o $12 \%$ das variações do estilo de liderança S4 são explicadas pela variável C. Isto é, a explicação é baixa. O restante $88 \%$ das variações de S4 estariam poderiam estar sendo explicadas por variáveis não contempladas neste estudo.

\subsubsection{Explicações dos resultados da análise de correlação do Grupo 4}

\section{Estilo de liderança Persuasivo (S2)}

O resultado da correlação do estilo de liderança S2 com o grau de maturidade dos seguidores R2 foram obtidos através da seguinte equação.

$$
\mathrm{S} 2=0,22+0,98 \mathrm{R} 2
$$

Observa-se uma alta influencia de R2 sobre S2, isto significa que os seguidores (R2) estão mais capacitados e possuem uma excelente atitude para o desempenho de tarefas, determinam com alta probabilidade uma resposta das enfermeiras diretivas, orientadas especialmente para os resultados e em menor grau para as relaciones interperssoais.

O Coeficiente de Correlação entre S2 e R2 $\left(R^{2}=0,63\right)$ indica uma alta relação entre as duas variáveis. Ou seja, a maturidade R2 dos seguidores influencia notavelmente sobre o estilo de liderança S2 das enfermeiras diretivas dos hospitales da cidade de México D.F.

\subsection{Análises dos dados de identidade}

O questionário "estilos de liderança" (Apêndice A) está dividido em duas partes: a primeira parte contempla os dados de identidade e a segunda os itens referentes aos estilos de liderança. 
Os resultados referentes aos dados de identidade são:

1) Cargo que ocupa: $100 \%$ foram dirigentes de enfermagem. Estes dados mostram a evidencia da necessidade da criação de cargos gerenciais, entre os profissionais da enfermagem, para exercer a gestão dentro do hospital. No passado, o cargo gerencial, não oferecia, à enfermagem, reconhecimento como dirigente (MEXICO, 1999a).

2) Direção e liderança são diferentes na prática?: os resultados indicam que $72 \%$ dos dirigentes consideraram que há diferença entre direção e liderança, ou seja, que depois de dar as diretrizes, é necessário captar a boa vontade e cooperação dos seguidores. Já o $28 \%$ dos dirigentes consideraram que direção e liderança têm o mesmo significado. Kotter (1990) refere que há diferença na maneira de executar. A direção planifica e formaliza estratégias, gerenciais e execução para alcançar os objetivos da organização. A liderança influencia e aporta com a dinamização das pessoas visando a alcançar as metas e os objetivos da organização. Em outras palavras, a direção define o marco de referência para a operacionalização da liderança. O ideal seria que o dirigente integre ambos os conceitos, assim, obter eficiência e eficácia em sua gestão.

3) Sexo: considera-se importante conhecer a participação do gênero dos dirigentes, já que, a enfermagem passou de ser uma profissão predominantemente feminina, a uma profissão com inclusão de profissionais do sexo masculino. Os resultados do presente estudo mostram que $100 \%$ dos participantes foram do sexo feminino. No México o $95 \%$ dos profissionais de enfermagem são do sexo feminino (México, 1999a).

4) Número de anos no cargo. A estabilidade do dirigente gera experiência, a qual é resultado do aprendizado no cargo. Quando há alta rotatividade no cargo, o líder se centraliza na etapa inicial da curva de aprendizagem: "sempre começando". Este fato desfavorece a maturidade da relação entre o líder e seus seguidores. Os resultados indicam que $81 \%$ dos dirigentes permanecem no cargo de um a dez anos. Isto significa que deixam o cargo na etapa 
de maior desenvolvimento de suas capacidade (BURELL; MORGAN, 2001). O investimento da organização, na formação de seus dirigentes, é perdido no momento em que o dirigente se afasta do cargo da organização. Nas entrevistas, aos dirigentes, com menos de 10 anos no cargo, manifestaram sentir estresse, angustia e muita pressão no cumprimento de suas tarefas. De outro lado, 2\% dos dirigentes com mais de 31 anos mostraram segurança e domínio em suas funções. Na figura seguinte verifica-se as porcentagens quanto a período da permanência no cargo dos dirigentes.

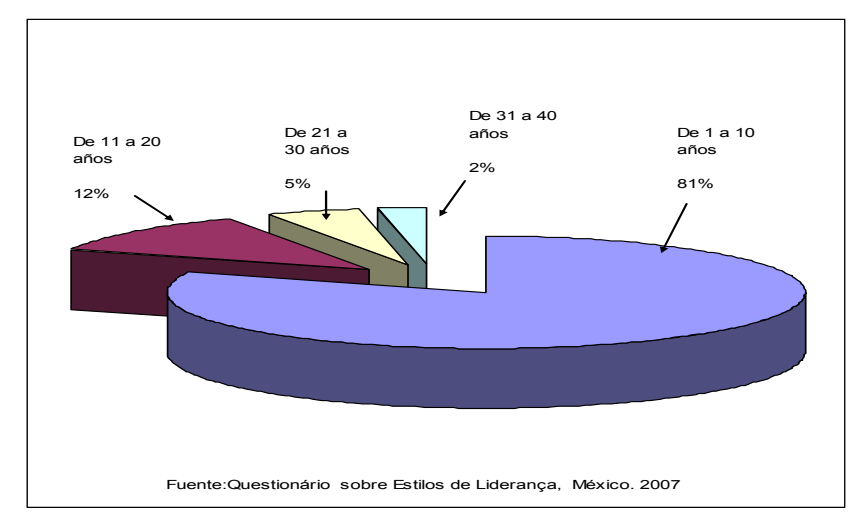

Figura 8 - Gráfico do período de permanência no cargo dirigente de Enfermagem nos hospitais gerais da cidade do México, D.F.

5) Horas diárias que seu cargo requer

Com esta pergunta buscou-se comprovar as informações obtidas com a pergunta anterior, já que o pessoal que têm menor experiência, no cargo, requer maiores horas de trabalho para cumprir suas funções. Já um dirigente com experiência alcança seus objetivos em menor tempo. Nos resultado se observou que $81 \%$ dos dirigentes requerem que mais de oito horas de trabalho. Fato observado, na experiência de trabalho da investigadora (25 anos), deste estudo, como dirigente e assessora das organizações hospitalares e desenvolvimento da comunidade. Burell e Morgan (2001) refere a importância do pesquisador como ator na investigação de fenômenos sociais, ou seja, na compreensão dos processos internos e intangíveis do pensamento humano. Assim, sendo valida a compreensão interpretativa da realidade por parte do investigador. 
Os hospitais são organizações complexas (MINTZBERG, 2004), razão pela qual, se requer de mais tempo na gerencia dos quatro períodos de trabalho da enfermagem. Também são organizações com tendência burocrática (WEBER, 1965), o que, torna complicado o manejo de documentação e a tomada de decisão, que é centralizada, e que contribuem com a necessidade de mais de oito horas de trabalho.

Na Figura 9 pode-se observar a distribuição de dirigentes que dedicam mais de oito horas diárias de trabalho no desempenho do cargo.

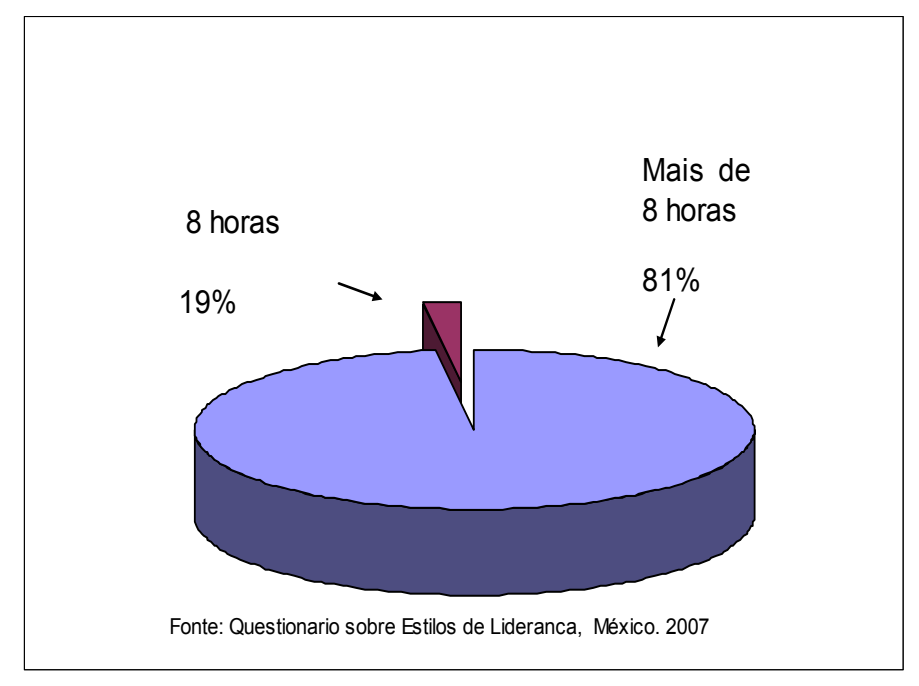

Figura 9 - Gráfico de distribuição segunda jornada de trabalho diária no desempenho do cargo

6) Número de enfermeiras sob sua direção. Os hospitais são organizações burocráticas, e os dirigentes devem tomar decisões centralizadas. Embora, não existam indicadores-padrão para o controle ótimo, sem duvida, o maior número de pessoas corresponde maior complexidade no processo de decisão. No presente estudo, $64 \%$ dos dirigentes têm sob sua responsabilidade entre 401 a 500 profissionais.

$\mathrm{Na}$ figura, abaixo, pode-se apreciar a distribuição do número de enfermeiros sob a responsabilidade do dirigente. 


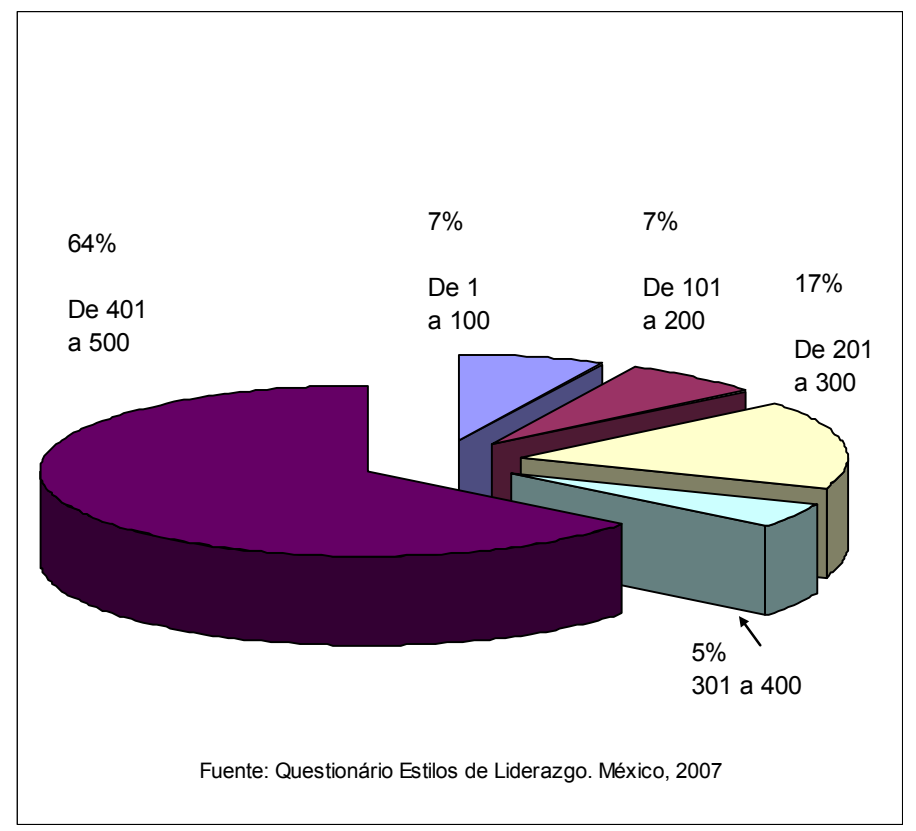

Figura 10 - Gráfico de distribuição do número de enfermeiros sob a responsabilidade do dirigente.

Os hospitais, estudados, são gerais e considerados de grande porte (PAGANINI, 1999). Somando-se o perfil burocrático, onde a tomada de decisões é centralizada, pode-se entender a complexidade do cargo dos dirigentes (THOMPSOM, 2002). Nas entrevistas, realizadas no presente estudo, os dirigentes referem excessivo trabalho e um ambiente estressante.

7) Grau de escolaridade. Os resultados referentes ao grau de preparação são favoráveis, $86 \%$ esta representado pelo nível universitário, o qual mostra que, a enfermagem mexicana, acompanha o desenvolvimento e avanços histórico-sociais. Fato que se torna importante na tomada de decisão e das ações da enfermagem. México (1999a) refere que, a preparação dos dirigentes, acompanhou o desenvolvimento da profissão. Os cargos dirigentes deixaram de ser ocupados pelo nível técnico e passaram a ser ocupados pelo nível universitário (MÉXICO, 1999a).

$\mathrm{Na}$ figura, abaixo, mostra o grau de preparação acadêmica dos dirigentes de enfermagem. 




Figura 11 - Gráfico de distribuição do grau de escolaridade dos enfermeiros, dos hospitais gerais de México, D.F.

\subsection{Descrição das respostas da entrevista semi-estruturada}

As respostas das entrevistas são integralmente apresentadas com caráter descritivo, o tempo de gravação foi de oito horas aproximadamente. Cumprem o papel de referentes nas coincidências e divergências ao considerar os resultados estatísticos.

Com base no objetivo proposto na entrevista semi-estructurada, buscou-se identificar a percepção dos dirigentes, em relação aos estilos de liderança, a maturidade de seus seguidores e ambiente de trabalho como parte das organizações hospitalares de saúde onde exercem seu trabalho. As entrevistas foram desenvolvidas com oito enfermeiros dirigentes de oito hospitais gerais da cidade de México, D. F. correspondentes à organização da Secretaria de Saúde do D. F.

Com base nos objetivos da pesquisa, de aprofundar no estudo do fenômeno de liderança, na entrevista se teve a necessidade de conhecer as opiniões dos dirigentes em relação à definição de liderança, estilos de liderança, maturidade de seus seguidores e o ambiente de trabalho, para tanto, foram respondidas quatro perguntas norteadoras: 


\section{1) Como você define liderança?}

Entrevistada (a) "a liderança a considero como um serviço, é a capacidade de servir...ajudar a conduzir grupos, mas de maneira especial com um elevado compromisso de serviço";

Entrevistada (b) “...liderança é a pessoa que lidera um grupo de companheiros de enfermagem...”.

Entrevistada (c) "há dois tipos de liderança, nata e a exercida através do cargo. Também, é liderança quando alguém lidera um grupo de companheiros de enfermagem";

Entrevistada (d) "a liderança é, dependendo de cada situação e de cada situação particular com os subordinados, há diferentes tipos de liderança, depende da organização institucional e das pessoas com as que se convive". problemas".

Entrevistada (e) "é a maneira de atuar frente a determinadas situações que se apresentam e resolver

Entrevistada $(f)$ "é uma parte importante da administração de qualquer organização onde deve ter um líder, com essa liderança se pode dirigir e organizar todos os serviços desde os dirigentes, todas temos algo de líder...temos que fazer uso para todos os serviços e em todos os períodos. A liderança é a base do êxito da organização de enfermagem".

Entrevistada (g) "é um conjunto de atributos que têm algumas pessoas e com isso convence a um grupo de pessoas que de convertem em líderes e o grupo es seus seguidores para conseguir um objetivo comum".

Entrevistada (h) "eu olho, como a capacidade das pessoas o de uma instituição de poder estar na frente, representar a cabeça do grupo ou de todo o hospital, sim eu acredito, que de forma geral, é o privilégio de ter esse guia, guia de maneira que pudesse ser natural sem usar o papel de autoridade que exerça algumas pessoas na instituição".

\section{2) Na sua percepção, que estilo de liderança oferece melhor êxito para você?}

Entrevistada (a) "depende do tipo de grupo com o que a gente enfrenta, porque se manejam grupos muito heterogêneos e cada grupo tem diferentes necessidades, um precisa se direcionar para as necessidades do grupo e de cada pessoa, ou seja, de maneira individual, não todas são iguais e as pessoas vão mudando de atitude para cada grupo ou para conduzir. A liderança que melhor êxito meu deu resultados foi aquele que considera o trato com o ser humano porque trato de ajudá-los. Considero que a parte emocional do trabalhador se projeta no rendimento. A liderança que mais satisfações me deu é a situacional, sempre que não seja autoritária, pois primeiro não me identifico com ela, e segundo não funciona com a gente. Entretanto, as vezes a aplico porque há pessoas difíceis e unicamente entendem quando recebem alguma ordem, coincidindo com o instrutivo".

Entrevistada (b) "o estilo de liderança que me satisfaz é quando misturo diferentes estilos segundo seja o caso de cada pessoa ou grupo, onde as decisões são tomadas em função do trabalho para benefício dos pacientes".

Entrevistada (c) "considero que é democrata já que todas as pessoas participam".

Entrevistada (d) "a situacional precisamente porque depende do tipo de gente que se relacione, é o grau que se exerce. A liderança definitivamente é definida conforme a situação vivida e a necessidade de manejar a equipe de trabalho".

Entrevistada (e) "pois eu digo que o democrático é positivo, muita gente poderia pensar que é autoritário. Acredito que todas as autoridades tentamos ser democratas. Esta forma de tratar aos trabalhadores tem funcionado, há problemas mas acredito que em nenhuma organizações termina, são parte da vida e da dinâmica da sociedade".

Entrevistada (f) "Bom aqui no hospital considero a mi critério que desenvolvemos, estilos combinados, os combinados porque para diferentes pessoas se usam diferentes estilos de liderança para lograr 
persuadi-lo, a vezes se precisa de um estilo de liderança mas não pode ser exercido, por que a lei interna do hospital determina o tipo de liderança e a gente tem que fazê-lo, assim exige o regulamento.... é difícil para a gente neste hospital, houve mudanças de política com os que não estávamos acostumados a trabalhar, tem sido difícil para todas essas mudanças e a criação e aplicação de normas. Eu digo, vamos a conhecer desde a norma ' mais simples'... mas, eu neste hospital uso diferentes tipos de liderança de acordo com a personalidade das enfermeiras, de acordo com o momento".

Entrevistada (g) "al liderança, a que exerço no momento, a considero democrática, porque no final obtenho bons resultados, , pois eu não gosto de ser impositiva, há coisas nas que a gente precisa decidir ...será feito isso porque deve ser assim, mas tem outras nas que eu solicito a opinião tanto da supervisão quanto dos dirigentes de serviço, para finalmente chegar a um acordo e todas estamos comprometidas... porque a vezes..não há compromisso... porque se é dito como uma ordem...não se comprometem. Então, meu estilo é democrático".

Entrevistada (h) "a liderança situacional, pois a gente precisa se adaptar aos estilos segundo seja a pessoa ou o grupo que está sendo dirigido...cada ser humano é único e diferente, logo eu não posso ser de igual estilo para todos".

\section{3) Na sua perspectiva, que conceito você tem dos membros da sua equipe em relação a suas fortalezas e debilidades no desempenho?}

Entrevistada (a) "minha equipe de trabalho é profissional, comprometido, disciplinado e com muitos desejos de superação, não somente pelo incentivo econômico senão pelo desenvolvimento profissional, procuram seguir estudando, fazer estudos de pós-graduação, o que é muito gratificante. São crítico e consultivos, as debilidades que percebo em alguns, é que as vezes se comportam com certa imaturidade, por exemplo, comentam...porque ele e eu não, há conflitos por interesse pessoais. Outra debilidade é a intolerância por não saber estabelecer um dialogo, há ressentimento e rancor. Há pessoas que são expertas em alguma coisa mas não o fazem por própria iniciativa".

Entrevistada (b) "O pessoal é responsável no trabalho...fazem bom uso dos recursos de capacitação para seu desempenho, isto ocorre na maioria dos casos porque há, também, pessoas que têm muita iniciativa e querem as coisas mas não sabem como...então acho que a capacitação é importante...básica para a operacionalizar o trabalho. Suas debilidades entre outras, é a freqüente aparição de conflitos,...emocionais e nem tanto cerebrais (lógicos). Outra debilidade é a dificuldade da comunicação que repercute nas relações humanas, pode-se observar várias enfermeiras que trabalham de maneira individual, não gostam de trabalhar em equipe, isto acredito, que em algum momento quebra as intenções, az vezes por situações que não foram esclarecidas e fazem que se isolem. Também se observa este fenômeno nos diferentes departamentos, a pouca comunicação. A falta de pessoal causa conflito e más relações humanas tendo um ambiente estressante. Existe também, falta de material e equipo o que causa tensão com todo o relacionado com prestação de serviços".

Entrevistada (c) "o pessoal intranqüilo, com desejos de superação, são pessoas esforçadas,... Existe conflito entre elas e nunca ficam em acordo se põem em acordo como grupo. A Antigüidade, torna alguns enfermeiros, conformistas, com pouco interesse pelos acontecimentos internos do hospital...referem que não é de interesse pois não tem relação com o seu serviço, alguns não gostam de assistir a cursos de treinamento, mencionam que se o salário aumentasse, então sim estariam interessadas, mas como não é possível, então não assistem".

Entrevistada (d) "eles têm pontos fortes e outros fracos. Os fortes ...têm ilusões, é um grupo pequeno com desejos de trabalhar, alguns desejam aprender novas coisas, para ascender, gostam de assistir a cursos programados no hospital, gostam de participar de atividades do hospital de tipo sócio político, entre outros. Os pontos fracos são entre outros, que são pessoas cansadas, pouco interessadas nos acontecimentos do hospital, embora têm muita experiência, não desejam colaborar mais. Realizam o mínimo entre suas funções, existem conflitos originados pela pouca comunicação entre eles, procuram seu benefício e pressionam o supervisor para obtê-lo, alguns ameaçam com faltar ao trabalho nos dias de maior necessidade".

Entrevistada (e) "é gente responsável, conhece suas funções, não precisamos estar supervisionando a ninguém...sabem trabalhar em equipe. Gosta de superação, estar atualizados nos avances de tratamento e técnicas avançadas, gostam de reuniões religiosas ou sociais ... como todo grupo humano, tem altas e baixas, az vezes surgem conflitos internos e é necessária a nossa intervenção. Grande parte do grupo de trabalho está cumprindo o tempo necessário da aposentadoria, isto contribui com que alguns se mostrem pouco satisfeitos com suas funções e não é de seu interesse continuar se preparando...”. 
Entrevistada (f) "acredito que há pessoas o bastante responsáveis que não requerem de um chefe...conhecem o que deve ser feito, são experientes...outras são jovens e mostram interesse em saber fazer... e solicitam cursos de aperfeiçoamento. Representam a base do hospital. Suas debilidades estariam representadas pela constante exigência de maiores direitos e menos obrigações, o que é complicado, pois não todo pode ser dado, se sentem descontentes e causam desconforto dentro do ambiente de trabalho. Existe resistência, por parte de algumas enfermeira para continuar se aperfeiçoando e não se interessam por assistir a curso recebendo o mesmo salário, não percebem que é necessário, pois vivemos na cultura da qualidade, onde o melhor permanece".

Entrevistada (g) “os membros da equipe de enfermagem são bastante trabalhadores, responsáveis, conhecem seu trabalho, têm muita experiência, muitos não requerem de supervisão, unicamente me procuram se avaliar algo sério e que somente eu possa resolver. Dentro de suas debilidades os membros do grupo mostramse bastante cansado ... e já não querem atualizá-se...e o atendimento médico avança dia a dia o que requer que estejam preparados. Az vezes a comunicação não é muito fluida tendo como conseqüência más interpretações que causam conflitos internos, a falta de trabalhadores o que aumenta a carga de trabalho ...originando, freqüentemente estresse".

Entrevistada (h) "é muito difícil qualificar da mesma maneira a todos, há pessoas muito responsáveis, mas outras requerem de supervisão constante...em uma organização a vários tipos de pessoas, há os que gostam de fazer as coisas, mas não sabem como, e outras que não desejam, mas sabem como fazer. Em uma organização como o hospital é muito complexo o comportamento das pessoas".

\section{4) Na sua percepção, como o ambiente de trabalho das organizações hospitalares da Secretaria de Saúde do Distrito Federal repercute em você?}

Entrevistada (a) "o ambiente tem uma combinação de várias atitudes, há um ambiente altamente normativo e não pode-se sair dele, isso causa angustia...devo ter sempre presente não fugir das normas para evitar conflitos com os dirigentes e com o sindicato de trabalhadores, ou seja, cuidar o regulamento em todos os sentidos... meus chefes são gente aberta, em constante superação, isso torna o ambiente de trabalho um pouco mais tranqüilo pode-se dialogar.Sem embargo, eles estão em uma estrutura hegemônica...médica...independente dos progressos dentro da enfermagem ainda estamos sujeitos à hegemonia médica...são eles os que ditam as políticas, diretrizes e isso torna o ambiente estressante...as vez os problemas de enfermagem não são tanto como dos médicos...exemplo disso é que à enfermeira não requer de ser lembrada constantemente o que deve fazer o paciente..conhece seu trabalho. Já, os médicos precisam ser lembrados e até procurados para que realizem as anotações médicas... algumas vezes não atendem por própria iniciativa, precisam ser lembrados.... Eu acho muito interessante o papel do líder, nesta profissão, me da muita satisfação o que faço, gosto a pesar de todo o estresse que a gente vive, pode-se colaborar com os colegas de trabalho, sinto-me realizada com a profissão"

Entrevistada (b) "o ambiente de trabalho esta rodeado de muitas regras como conseqüência do preenchimento de documentos, isto é mais importantes que as ações...isto faz com que a instituição diminua sua imagem por falta de atendimento...como chefe sinto-me impossibilitada de muitas coisas dentro do hospital, pois não depende de mim, sinto-me frustrada, pelo que desejo fazer e não tenho como. Mas eu faço o que posso, em função disso, é que eu venho trabalhando. Este tipo de ambiente me deixa sentimento de incompetência, frustração, sinto-me altamente estressada por ver os problemas e não poder dar solução. Outra parte que causa estresse, também é o centralismo tão marcado...pedem informação com muita freqüência, com determinados critérios a cumprir e com um tempo curto. $\mathrm{O}$ espaço físico, onde trabalho, não reúne as condições mínimas de higiene e segurança. A desculpa é a escassez de recursos financeiros. Isto me deprime, ainda mais. Existe a promessa de passar ao local próprio, já que este é improvisado e por essa razão não reúne as mínimas condições, esperarei com paciência esse dia".

Entrevistada (c) "no hospital se devem cumprir passo a passo todas as instruções normalizadas e improvisar equipes para o atendimento de enfermagem, pois a maior parte das áreas hospitalares crescem de forma elementar (medicamentos, roupa, material, entre outros), isso me preocupa todos os dias e cada vez chegam mais pacientes e não sabemos como serão atendidos. O diretor estabelece as relações públicas externas, mas são atendidos em nível central, que no momento deve-se trabalhar com o hospital conta...Devemos esperar um pouco. Este período me causa estresse e angustia, sinto-me frustrada pelo que acontece em meu hospital, sem poder fazer quase nada, em parte é responsabilidade política”. 
Entrevistada (d) "a cobertura dos serviços cada vez é maior e a oferta do hospital é menor, isto causa angustia, ademais os problemas de saúde cada vez são mais complexos e não se conta com os recursos para satisfazer todas as necessidades da população, isso origina problemas de relações humanas, pouca satisfação no trabalho, o ambiente é pesado. E em particular, me sinto muito comprometida com o serviço de enfermagem e percebo o estresse dos trabalhados... É impossível que seja temporária...".

Entrevistada (e) "o ambiente de trabalho é bom, há respeito e confiança entre os colegas e em toda a organização hospitalar. Observam-se algumas dificuldades como a falta de recursos humanos, materiais e tecnológicos. Eu vivo com tranqüilidade e tenho as mesmas preocupações dos chefes pela falta de recursos e a demanda de trabalho, mas nada ganho com estar angustiada, se eu não posso resolver, a gente faz o que pode".

Entrevistada (f) "o ambiente de um hospital, sempre é estressante, pois se trabalha com a vida e a morte. No hospital faltam recursos, como sou responsável de administrar, me causa uma sensação de impotência, pois não há condições de oferecer todo à equipe de trabalho. Ademais, vivemos em uma administração centralizada, o que gera constantes pedidos de informação, com a qual muitas vezes não contamos, cumprindo-se assim outras exigências. $O$ ambiente é altamente burocrático, isso causa intranqüilidade".

Entrevistada (g) “é um ambiente sob muitas normas, razão pela qual sempre deve-se ter presente as normas e regulamentos para o bom funcionamento do hospital. A avaliação é a constante. Isso causa freqüente angustia, para o cumprimento das metas, as tarefas. Causa forte pressão, sempre há presa para tudo, o dia termina com muito cansaço".

Entrevistada (h) "o ambiente de um hospital é complexo pela variedade de serviços e especialidades, isto o torna único e sinto-me confortável, mas não deixo de sentir estresse todos os dias, para que todo seja corretamente realizado, já que não depende unicamente do meu cuidado, também de outras circunstâncias do ambiente".

As expressões dos participantes coincidem em que o ambiente hospitalar funciona sob normas estritas, com regulamentos, técnicas bem definidas e rotinas. É um ambiente altamente padronizado, dados que coincidem com as características descritas no modelo burocrático de Weber (1998). Essas organizações são orientadas ao cumprimento de tarefas, o qual é relacionado ao estilo de liderança persuasiva, que é caracterizado por oferecer uma liderança diretiva, com apoio para reforçar a disposição e entusiasmo dos seguidores. Essas condições são apropriadas para os traços da Conduta Tipo A, dos dirigentes de enfermagem, aqui há uma contradição. Estatisticamente os resultados, não são significantes, porém, os dirigentes, nas entrevistas, expressam a existência da percepção de traços de Conduta Tipo A. Com essas descrições se concretiza a apreciação dos elementos coincidentes entre as opiniões dos sujeitos entrevistados.

Depois da transcrição das respostas dos sujeitos entrevistados apresentadas integramente foi elaborado o Quadro 10 que contempla as coincidências e controvérsias dos oito sujeitos entrevistados em relação com as quatro perguntas feitas nas entrevistas. As 
quatro perguntas aparecem no quadro com as essências de cada uma das respostas dos entrevistados.

Quadro 10 - Apresentação dos elementos coincidentes em relação com as respostas dos Sujeitos Entrevistados

\begin{tabular}{|c|c|c|c|c|c|}
\hline \multirow{2}{*}{$\searrow_{\text {Sujeitos }}^{\text {Pergun }}$} & \multirow[t]{2}{*}{$\begin{array}{l}\text { Definição de } \\
\text { Liderança }\end{array}$} & \multirow[t]{2}{*}{$\begin{array}{l}\text { Estilo que lhe } \\
\text { oferece êxito }\end{array}$} & \multicolumn{2}{|c|}{$\begin{array}{l}\text { Percepção dos dirigentes em relação aos } \\
\text { seus seguidores }\end{array}$} & \multirow[t]{2}{*}{$\begin{array}{l}\text { Como percebe o } \\
\text { ambiente de trabalho }\end{array}$} \\
\hline & & & Fortalezas & Debilidades & \\
\hline A & $\begin{array}{l}\text { Conduzir } \\
\text { grupos, } \\
\text { serviço }\end{array}$ & $\begin{array}{l}\text { Situacional } \\
\text { comunicação }\end{array}$ & $\begin{array}{l}\text { Profissionais } \\
\text { comprometidos, } \\
\text { desejos } \\
\text { superação, } \\
\text { disciplinado }\end{array}$ & $\begin{array}{l}\text { Certo grau de } \\
\text { imaturidade, } \\
\text { intolerância, } \\
\text { pouca iniciativa }\end{array}$ & $\begin{array}{l}\text { Normativo, } \\
\text { hegemonia do } \\
\text { médico, excesso de } \\
\text { regulamentação, } \\
\text { rigidez, estresse, } \\
\text { obediência de ordens } \\
\text { do centralismo }\end{array}$ \\
\hline B & $\begin{array}{l}\text { Liderar a um } \\
\text { grupo, trata-se } \\
\text { de satisfazer a } \\
\text { todas } \\
\text { pessoas }\end{array}$ & $\begin{array}{l}\text { Combinação } \\
\text { de estilos de } \\
\text { liderança }\end{array}$ & $\begin{array}{l}\text { Responsável e com } \\
\text { iniciativa }\end{array}$ & $\begin{array}{l}\text { Pouca } \\
\text { comunicação, } \\
\text { conflitos }\end{array}$ & $\begin{array}{l}\text { Sentimento de } \\
\text { limitação, } \\
\text { frustração, estresse, } \\
\text { muitas orientações } \\
\text { centralizadas }\end{array}$ \\
\hline $\mathrm{C}$ & $\begin{array}{l}\text { Exercida } \\
\text { através do } \\
\text { cargo }\end{array}$ & Democrático & $\begin{array}{lr}\text { Pessoas } & \text { inquietas, } \\
\text { desejos } & \text { de } \\
\text { superação } & \end{array}$ & $\begin{array}{l}\text { Pessoas } \\
\text { cansadas, } \\
\text { conflitos }\end{array}$ & $\begin{array}{l}\text { Escassez de recursos } \\
\text { para o cuidado } \\
\text { preocupa, } \\
\text { mudança de governo } \\
\text { causa estresse e } \\
\text { angustia }\end{array}$ \\
\hline $\mathrm{D}$ & $\begin{array}{lr}\text { Depende } & \text { da } \\
\text { instituição } & \text { e } \\
\text { situação } & \end{array}$ & Situacional & $\begin{array}{l}\text { Desejos } \\
\text { superação }\end{array}$ & $\begin{array}{l}\text { Pessoas } \\
\text { cansadas, pouca } \\
\text { comunicação, } \\
\text { conflitos }\end{array}$ & $\begin{array}{l}\text { A oferta de serviços } \\
\text { é baixa, comparada } \\
\text { com a demanda, } \\
\text { causa angustia, } \\
\text { pouca satisfação }\end{array}$ \\
\hline $\mathrm{E}$ & $\begin{array}{l}\text { É a forma de } \\
\text { atuar frente } \mathrm{a} \\
\text { situações } \\
\text { resolver } \\
\text { problemas }\end{array}$ & Democrático & $\begin{array}{l}\text { Pessoas amáveis, } \\
\text { responsáveis, } \\
\text { trabalha em equipe, } \\
\text { gostam da } \\
\text { convivência }\end{array}$ & $\begin{array}{l}\text { Algumas } \\
\text { pessoas } \\
\text { cansadas, pouco } \\
\text { satisfeitas, } \\
\text { conflitos } \\
\text { internos }\end{array}$ & $\begin{array}{l}\text { Há respeito } \\
\text { confiança entre os } \\
\text { colegas, } \\
\text { tranqüilidade }\end{array}$ \\
\hline $\mathrm{F}$ & $\begin{array}{l}\dot{E} \text { uma parte } \\
\text { importante da } \\
\text { administração }\end{array}$ & $\begin{array}{l}\text { Combinação } \\
\text { de estilo e } \\
\text { mais } \\
\text { persuasivo }\end{array}$ & $\begin{array}{l}\text { São responsáveis e } \\
\text { com muita } \\
\text { experiência }\end{array}$ & $\begin{array}{l}\text { Algumas } \\
\text { pessoas com } \\
\text { pouca } \\
\text { disposição para } \\
\text { a superação }\end{array}$ & $\begin{array}{l}\text { O ambiente } \\
\text { hospitalar } \\
\text { estressante, } \\
\text { escassez de recursos } \\
\text { causa impotência, é } \\
\text { burocratizado }\end{array}$ \\
\hline G & $\begin{array}{l}\text { Conjunto de } \\
\text { atributos de } \\
\text { uma pessoa, } \\
\text { convencem o } \\
\text { grupo }\end{array}$ & Democrático & $\begin{array}{l}\text { Responsável com } \\
\text { experiência }\end{array}$ & $\begin{array}{l}\text { Pouca } \\
\text { comunicação, } \\
\text { algumas pessoas } \\
\text { muito cansadas }\end{array}$ & $\begin{array}{lr}\text { Ambiente } & \text { com } \\
\text { bastantes normas, a } \\
\text { avaliação constante } \\
\text { causa angustia, } \\
\text { pressão e cansaço }\end{array}$ \\
\hline $\mathrm{H}$ & $\begin{array}{l}\text { Capacidade de } \\
\text { uma pessoa de } \\
\text { ser a "cabeça" } \\
\text { do grupo, guia }\end{array}$ & Situacional & $\begin{array}{l}\text { Pessoa muito } \\
\text { responsável }\end{array}$ & $\begin{array}{l}\text { Algumas } \\
\text { requerem } \\
\text { supervisão } \\
\text { constante }\end{array}$ & $\begin{array}{l}\text { O ambiente é } \\
\text { complexo, sente-se } \\
\text { angustia todos os } \\
\text { dias }\end{array}$ \\
\hline
\end{tabular}


As respostas das quatro perguntas norteadoras permitem observar o panorama da percepção dos dirigentes sobre o fenômeno de liderança. Chama nossa atenção, a primeira resposta, na sua definição de liderança aprecia pouca relação com o que é concebido por Hersey e Blanchard (1988): liderança situacional "é o processo de influenciar nas atividades dos seguidores ou grupos para o alcance de um fim comum".

Na segunda resposta, em relação aos estilos de liderança, Hersey e Blanchard (1988) referem que "o estilo é o padrão de comportamento, que a líder manifesta, quando procura influenciar nas atividades das outras pessoas, e como isso é visto por essas pessoas”. Este conceito desenvolve uma combinação de dois tipos de comportamento, tarefa e relacionamento. Nesta resposta existem vários estilos de liderança que deu êxito, predominando o democrático. Nos resultados estatísticos (Figura 9) observa-se a presença dos quatro estilos de liderança, com explicação significativa do estilo persuasivo com um resultado do estilo de liderança persuasivo $\mathrm{S} 2$ com um coeficiente de determinação de $\mathrm{R}^{2}$ 0,51 .

$\mathrm{Na}$ terceira resposta, onde se procurou conhecer a percepção da maturidade dos seguidores, Hersey e Blanchard (1988) a define como "a capacidade e a disposição das pessoas em assumir a responsabilidade de dirigir seu próprio comportamento”. Os autores incluem, neste conceito, a maturidade em duas dimensões: maturidade no trabalho (capacidade) e maturidade psicológica (disposição). No Quadro 10 se descrevem as percepções dos seguidores, relacionando essas percepções com os resultados estatísticos na Figura 5. Observa-se a relação entre estilos de liderança com os tipos de maturidade. Também, observa-se na Figura 7, a associação entre os quatro estilos e quatro graus de maturidade, ressaltando seu significado na duplicidade. O estilo S2 e a maturidade R2 foram explicados em 63\%. Observa-se uma relação entre o percebido, e há uma combinação de maturidade. 
Na quarta resposta, como é percebido o ambiente de trabalho do hospital. No Quadro 10 observa-se uma tendência de organizações burocráticas, com descrição de atributos mencionados no marco teórico, tendo como conseqüência um ambiente estressante, ambiente propício para a o desenvolvimento de traços de conduta tipo A. Nos resultados estatísticos, chama a atenção, Figura 6 esta relação, já que os valores não são significantes, entretanto, estão presentes na realidade dos sujeitos entrevistados. Esses resultados requerem de ser estudados em profundidades por representarem uma preocupação, como assim descrito por Friedman e Rosenman (1976); Torres (1995); Simon, Hertsz (2003); Lankton (2004) e Moreno (2005), entre outros, e descrito no marco teórico. Este fenômeno influencia na saúde dos dirigentes.

Para completar o processo de análises, entre os resultados estatísticos e as entrevistas foram observadas as características pessoais e de trabalho dos enfermeiros dirigentes, descritos nas Figuras 8, 9, 10 e 11, dados que permitem uma melhor observação dos sujeitos.

Jornada de trabalho Figura 9, o $81 \%$ dos enfermeiros dirigentes têm uma jornada de trabalho superior a oito horas. As possíveis causam são: sobrecarga de trabalho, omissões dos trabalhadores subordinados, baixa produtividade dos subordinados, mudanças nos programas de políticas centrais, excesso de procedimentos burocráticos (documentação), mecanicismo, indolência e anonimato nas funções, de tendência funcionalista por dedução do ambiente burocrático percebido pelos sujeitos do estudo. Estas considerações têm semelhança com as encontradas por Trevizan (1988), que 74\% das funções administrativas, realizadas pelos enfermeiros estão fundamentadas no modelo burocrático de Weber, indicando uma tendência para um serviço rotineiro e impessoal e, portanto, uma vinculação mais acentuada a normas préestabelecidas. (LEONARDI, 2004) refere é importante considerar que o estudo realizado compreendeu um período de estudo de treze anos Trevizan (1988).

As opiniões dos dirigentes de enfermagem confirmam, em parte, a burocracia weberiana: "é uma tentativa de formalizar e coordenar o comportamento humano por meio do exercício da 
autoridade racional-legal, para o alcance dos objetivos das organizações gerais" (MOTTA; VASCONCELOS, 2002).

$\mathrm{Na}$ Figura 10, observa-se que $64 \%$ encarregam-se de 401 a 500 seguidores de enfermagem. Em organizações com perfil burocrático, onde a autoridade e tomada de decisões devem ser realizadas pelos superiores, por tanto representa uma forte carga de trabalho. Ao respeito Mintzberg (2004) refere que em organizações burocráticas a direção é assumida diretamente pelos cargos superiores, requerendo poucos assessores, mandos intermediários e mecanismos de controle.

No que se refere ao período de desempenho nos cargos dirigentes Figura 8 verifica-se que o $81 \%$ tem de um a dez anos. Há uma alta rotatividade, o que poderia estar relacionado com a busca de um melhor ambiente de trabalho ou por estar submetido à obediência de dirigentes da organização que frente à desobediência dispensam os seus serviços (BECERRIL, 2005).

Em relação aos níveis de preparação Figura 11, observa-se que 62 \% licenciatura e 24\% pós-graduação e só $14 \%$ nível técnico. A escolaridade mostra uma alta dinâmica da superação. A preparação está relacionada com os cargos dirigentes. No México, os cargos dirigentes têm melhor nível de preparação, já que há dez anos a maior parte dos dirigentes estava representada pelo nível técnico (MÉXICO, 1999a) atualmente o maior número corresponde a enfermeiros com licenciatura e com tendência à pós-graduação.

Com esses resultados cumpriram-se os objetivos traçados na investigação e é comprovada a hipóteses da existência de correlações entre os estilos de liderança, maturidade e dos indícios de traços de conduta tipo A, nos dirigentes de enfermagem dos hospitais gerais da cidade do México, Distrito Federal. 
O tema sobre o conhecimento do fenômeno de liderança, no México, tem sido pouco estudado e a necessidade de seu estudo é evidenciada no cotidiano da prática profissional. Com a proposta, deste estudo, foi possível conhecer os seguintes aspectos de liderança em enfermagem nos hospitais gerais da cidade do México, Distrito Federal:

a. A maior parte dos dirigentes são relativamente jovens devido à alta rotatividade do cargo;

b. Os dirigentes mexicanos estudados têm alta orientação para a Conduta de Tipo A;

c. Há uma significante correlação entre o estilo de liderança persuasivo e a conduta reativa dos seguidores;

d. Os dirigentes referem que seus cargos são estressantes e que, embora, tenham uma qualificada formação acadêmica e desempenhem as mesmas funções de outros dirigentes, que não da área de enfermagem, não recebem um trato eqüitativo;

O estudo da liderança e conhecimento do ambiente de trabalho do líder, dentro SNS, permitiu a identificação de percepções de tensão no trabalho, tendência à perda da hierarquia, perda de valores, esforços não reconhecidos e a frustração do desejo de trabalho estável, gratificante e socialmente reconhecido. Situações como essas, aumentam a distância entre os objetivos pessoais e institucionais, do SNS, concluindo em uma prestação de serviços pouco humanizada.

A importância do presente estudo, para os dirigentes dos hospitais, concentra-se na evidencia da orientação para a Conduta de Tipo A. O conhecimento, por parte dos dirigentes, das características e conseqüências, deste tipo de conduta, se torna importante, já que contribui com a eficácia de sua liderança.

A presença dos Traços de Conduta Tipo A, nos sujeitos estudados, tanto na análise estatística, quanto nas entrevistas, são percebidos com clareza. Entendemos que seja necessário o estudo, em maior profundidade, do fenômeno. É necessário contar com o apoio de grupos 
interdisciplinares, para a busca da prevenção da Conduta Tipo A. Assim, os diretivos/líderes poderão desenvolver suas habilidades com saúde e qualidade de vida desejada.

As instituições, formadoras de enfermeiros, têm a responsabilidade de dar ênfase nos aspectos funcionais da profissão. No entanto, os princípios de administração, liderança e organização, representam o suporte para o acesso a cargos diretivos em condições competitivas.

A liderança em enfermagem requer grandes mudanças na formação e na gestão. Deve inter-relacionar e fortalecer-se com a formação nas escolas de enfermagem, as quais devem fazer uma revisão dos conteúdos curriculares relacionados com a liderança e direção, de maneira que possam propor estratégias que modifiquem e viabilizem o processo de ensino-aprendizagem sobre diferentes cenários da liderança.

O enfoque de gestão acontecerá pela educação continuada, com programas de atualização que visem à concepção da liderança e direção como um binômio proposital. Consideração prosposta por outros investigadores como Villalobos (1988); Blais, Farris (1988); Méndes (1994); Becerril (2004) e CIE (2005), entre outros. Assim, deve-se proporcionar discussão do fenômeno de liderança por meio de fórum, seminários, entre outros, com a participação de peritos, e as novas gerações de enfermagem para despertar o interesse de líderes potencialmente críticos e reflexivos.

Outro aspecto importante, é que o enfermeiro que ocupa cargos diretivos atue como líder, que propicie caminhos para o desenvolvimento e aperfeiçoamento dos estilos de liderança e se inter-relacione com os profissionais de enfermagem, incentivando o espírito de trabalho em equipe, com articulação e representando no SNS. 
Enfermagem como profissão tem grandes desafios, pois se desenvolve em organizações com perfil de tendência burocrático-funcionalista, razão pela qual, precisam procurar estratégias viáveis para a mudança, que se adaptem à realidade com conhecimento, perseverança e assertividade. Não esquecendo que a mudança se inicia na pessoa e depois se socializa.

O presente estudo põe em evidencia a relação entre o estilo de liderança e o grau de maturidade dos seguidores. O modelo de liderança situacional esta contida dentro da teoria de liderança, que ressalta a capacidade de condicionamento do estilo do líder, frente às atitudes de seus seguidores. Assim também, no estudo, foi observado o comportamento reativo dos seguidores (bom grau de preparação e baixo grau de cooperação). Isto não significa que os seguidores sejam permanentemente reativos e que o líder, também, seja permanentemente persuasivo. Os seguidores podem mudar de atitude, desde a inatividade ou passividade até a iniciativa ou cooperação, sendo que, o estilo de liderança, também pode ser flexível, acompanhando a mudança de atitude de seus seguidores, mudando de estilo diretivo até o estilo delegatorio.

Características como essa, permitem, aos dirigentes, enfrentar o desafio de formar seguidores dentro de um ambiente de decisões restritas, devido à orientação burocrática hospitalar, sem a necessidade de resolver as deficiências dos seguidores por méio de jornadas extensas de trabalho.

O resultado do estudo, sobre a opinião dos dirigentes de enfermagem, põe de manifesto conhecimentos sobre seu cargo, dos trabalhadores e da instituição. Isto pode ser comparado com a de outros dirigentes, visando à melhora do entendimento da realidade em que se encontra.

Relacionado ao conhecimento de liderança, este estudo contribui na verificação do modelo de liderança situacional, no contexto das organizações de serviços de saúde e na compreensão, deste fenômeno social, mediante técnicas quantitativas e qualitativas. 
De outro lado, a investigação oferece suporte para a realização de outras investigações que tenham como objetivos: estudar a semelhança entre os estilos de liderança nas instituições, a correlação entre os estilos de liderança e os graus de maturidade dos seguidores, nas instituições do SNS, e conhecer os fatores (variáveis) que devem ser incluídos na investigação para melhorar a adaptação do modelo de Hersey e blanchard (1988) para ser aplicado no SNS do México.

A criação de uma linha de investigação para o estudo de liderança em enfermagem, no México, permitiria a ampliação do conhecimento de aspectos ontológicos (como, realismo e nominalismo), epistemológicos (como, positivismo e antipositivismo), metodologia (ideográfica e nomotêtica) e sociológicos (como, status quo e mudança radical) entre outros (BURELL; MORGAN, 2001)

Investigações futuras podem estar orientadas ao estudo da alta rotatividade dos dirigentes e a formas de apoio que forneçam maior autonomia nas decisões, visando a ampliar o campo de desempenho. Assim, os resultados poderiam contribuir na diminuição do estresse dos dirigentes e na melhora da formação de seguidores e, como conseqüência, a melhora da qualidade dos serviços prestados aos usuários.

Espera-se, que a presente pesquisa, possa oferecer o desenvolvimento de linha de investigação que vise à continuidade do estudo do fenômeno de liderança de enfermagem no México, de forma que permita encontrar caminhos apropriados para o exercício de uma liderança proposital, em benefício da profissão para o campo da saúde, com impacto direto na sociedade mexicana.

Finalmente, esta investigação representa uma base de apoio metodológico para investigadores orientados ao estudo do fenômeno "Liderança em Enfermagem". 
6. REFERÊNCIAS 
ABBAGNANO, N. Diccionario de filosofía. 2 ed. México: Fondo de Cultura Económica, 1974.

ACKOFF, R. Rediseñando el futuro. México: Limusa, 1993.

ALARCÓN, G. N. La profesionalización en enfermería y su impacto social. México: Colegio Nacional de Enfermeras, 1998.

ANTUNES, A. V.; TREVIZAN, M. A. Gerenciamento da qualidade: utilização no serviço de enfermagem. Revista Latino-americana. Enfermagem, Ribeirão Preto, v.8, n.1, p. 35-44, Janeiro, 2000.

ARIAS, M. M. La triangulación metodológica: sus principios, alcances y limitaciones. Antología. México: Iberoamericana, 2002.

BECERRIL, C. L. et al. Educación y práctica de enfermería en México. Revista Nursing, México, v.4, p. 56-162, mayo, 2004.

BECERRIL, C. L. La profesionalización de la enfermería en México: un análisis desde la sociología de las profesiones. México: Pomares, 2005.

BERMEO, M. F. et al. Poblanas en la salud pública de México. Historias de vida y semblanza, H. México: Ayuntamiento de Puebla, 2002.

BERMEO, M. F.; GUZMAN, V. I. et al. Enfermería disciplina científica: Una aproximación epistemológica. México: Universidad Autónoma de San Luís Potosí, 1995.

BLAIS, K. K.; FARRIS, L. Models for leadership development. International Nursing. Review, v. 35, n. 6, p. 172-174, 1988.

BLAKE, R. R.; MOUTON, J.S. O Grid Gerencial III. 4 ed. Trad. Luiza Elza Massena. São Paulo: Pioneira, 1997.

BLANCHARD, K.; ZIGARMI. Liderazgo y el minuto del directivo. New York: William Monrrow, 1985.

BURRELL, G.; MORGAN G. Sociological paradigms and organisational analysis. England: Ashgate, 2001.

CAMPBELL J.P. On the nature of organizational effectiveness. San Francisco. USA: Jossey - Bass, 1977.

CAMPBELL, R. Leadership studies. USA: Upper Saddle River, 1995.

CASASA , G. P. Aspectos ideológicos y socioeconómicos que inciden en la formación del profesional de enfermería. Revista Enfermeras, IMSS, v. 38, n. 3. p. 7-9, mayo-junio, 2001.

CHIAVENATO, I. Introducción a la teoría general de la administración. 5. ed. México: Mc Graw Hill, 2000. 

$\overline{\text { Hill, } 2005 .}$

*. Introducción a la teoría general de la administración. 6. ed. México: Mc Graw

*. Introducción a la teoría general de la administración. 7. Ed. México: Mc Graw $\overline{\text { Hill, } 2006 .}$

CHUNG, K. Study guide experimental exercises. Massachussets: Lussier. Allyn and Bacon, 1990.

CONSEJO INTERNACIONAL DE ENFERMERAS (CIE). Preparación de la enfermera administradora y la enfermera en la administración general de salud. Ginebra Suiza: Informe, 1985.

*. Declaración oficial sobre los contenidos del programa de administración para enfermería. Pautas para asociaciones nacionales de enfermeras y de más interesados. Informe Ginebra Suiza: CIE, 1987.

*. Proyecto de reglamentación. II Taller. Tlaxcala, México: Memorias, 1989.

*. Pautas para asociaciones nacionales de enfermeras y de más interesados: Preparación de la enfermera administradora y la enfermera en la administración general de salud. Ginebra Suiza: Informe, 1990a.

*. Pautas para los programas de liderazgo y administración en enfermería para asociaciones nacionales de enfermeras. Ginebra Suiza Informe, 2005.

CORDERA, A.; BOBENRIETH, M. Administración de sistemas de salud. México: Cordera y Bobenrieth, 1992 Tomo 1 y 2.

DE GORTARI, E. Diccionario de la lógica. México: Plaza y Valdes, 2000.

DÍAZ MÉRIGO, A. Eı Dirigente. 2. ed. México: Mc GrawHill. 1982.

DRUCKER, T. Las organizaciones Postcapitalistas. México: Mc GrawHill, 2000.

ELIZONDO, T. Historia de enfermería México: Prensa Médica Mexicana, 1998.

ESPINO, V. M. E. et al. Avances en el currículo de enfermería In: Jornada científica cultural del aniversario, 7 Centro Médico Nacional siglo XXI. México: Instituto Mexicano del Seguro Social, 1997.

FAYOL, H. Administración industrial y general. México: Herrero Hnos, 1997.

FERRAZ, G. A. A transfiguração da administração em enfermagem: da gerência científica a gerência sensível. 1998. 248. Dissertação (Doutorado em Enfermagem) - Escola de Enfermagem de Ribeirão Preto, Universidade de São Paulo, Brasil, 1998.

FIEDLER, F. A theory of leadership effectiveness. New York: Mc Graw Hill, 1967. 
FLORES, S. E. Ausencia de órganos normativos para enfermería. ¿Qué factores lo han determinado?. 1994. 168 p. Disertación (Maestria en enfermería) -. Escuela Nacional de Enfermería y Obstetricia, Universidad Nacional Autónoma de México, México, 1994.

FOUCAULT, M. Microfísica do poder. 2 ed. Brasil: Graal, 1981.

FRANK, C. M.; ELIZONDO, T. Desarrollo histórico de la enfermería. México: Prensa Médica Mexicana, 1987.

FREIDSON, E. La profesión médica: un estudio de sociología del conocimiento aplicado. Barcelona: Península, 1978.

FRENK, M, J. Seguro popular de salud, forma parte de la reforma democrática. México: Periódico, 15 octubre, 2003. Economía.

*. Seguro Popular de Salud en México. Periodismo de Ciencia y Tecnología. México: Investigación y desarrollo, 2001.

FRIEDMAN M.; ROSENMAN R. H. Conducta tipo A y su corazón. España: Grijalbo, 1976.

GALVÃO, M. C. Liderança situacional: uma contribuição ao trabalho do enfermeirolíder no contexto hospitalar. 1995. Tese (Doutorado em Enfermagem)- Escola de Enfermagem, Ribeirão Preto, Universidade de São Paulo, 1995.

GARCIA. J. M. A. et al. Identificación de la conducta de los directivos de enfermería según la teoría de Friedman y Rosenman. In: X Coloquio panamericano de investigación en enfermería: Buenos Aires, Argentina, 2005.

GARCÍA, J. M. A.; MONROY, R. A.; MORENO, F. G. Administración-Enfermería en las organizaciones hospitalarias. México: Asociación de Escuelas de Enfermería del DF, 2004.

GAYTAN, T. Liderazgo en la teoría, en la ética y en la mujer. España: Comunidad virtual, 2005.

GEORGE, C. Historia del pensamiento administrativo. México: Prentice Hall, 1987.

GIL, M. V. Los procesos de salud-enfermedad en el contexto actual de la medicina en México, Vinculando, 58, 3 noviembre, 1997.

GOMES, R.; SOUZA, E. R. EI desafió de la triangulación. Evaluación por triangulación de métodos. Rio de Janeiro: Campus, 2005.

GRANSCI, A. Os intelectuais e a organização da cultura. 4. ed. São Paulo: Civilização Brasileira, 1982.

HERSEY P. BLANCHARD, K. Management of organizational behavior. USA: Prentice Hall, 1988. 
* ; JOHNSON, D. E. Management of organizational behavior. Leading human recurces. 8 ed. USA: Upper Saddle River, 2001.

HIGA, E. F. R.\& TREVIZAN, M. A.; O estilos de liderança idealizados pelos enfermeiros. Revista Latino-americana, Enfermagem, Ribeirão Preto, v.13, n.1, p. 59-64, janeirofevereiro, 2005.

HINICH, H. Triunfos y fracasos de la medicina en los Estados Unidos Americanos: Gaceta Médica, Mexicana, v.12, p.72-76, 1990.

JOHANSEN, B. O. Anatomía de la empresa. México: LIMUSA, 1996.

KAST, F.; ROSENZWEIG, J. Administración en las organizaciones: enfoque de sistemas y contingencias. 4. ed. México: Mc Graw Hill, 1994.

KNICKERBOCKER, I. Liderança: um conceito e algumas implicações. Rio de Janeiro: Fundação Getulio Vargas, 1967.

KOTTER, J. A. Force for change: How leadership differs from management. New York: Free Press, 1990

LANDGRAVE, C. G.; TETELBOING C. La trayectoria del papel del estado en el área de la salud, desde 1917 hasta nuestros días. Revista Medicina Social, México, v, 2, n 5, p. 234246, 2006.

LANKTON, C. H. Transforming type A personality. How to tell Who has A Type personality A. Texas: Heart Institute Journal, 2004.

LAURELL, A. C. Mexicanos en defensa de la salud y la seguridad social. Cómo garantizar y ampliar tus conquistas históricas. México: Planeta Mexicana, 2004.

LAURELL, A. C. et al. Reducción de la exclusión en salud removiendo el obstáculo económico. La experiencia del gobierno del Distrito Federal. México: SSDF, 2005.

LEAL, G. La política publica de salud y seguridad social en México y el mundo (19962000). México: UAM, 2004. Serie Académicos CBS, 48.

LEDDY, S. PEPPER, M. Bases conceptuales de la enfermería profesional. Washington D. C: OPS, 1989.

LEIJA, P. O. E. La labor social de la enfermera. México: Convención Nacional de Enfermeras. Hospital Juárez., 1954.

LEONARDI, M. Contribuição das teorias administrativas na produção do conhecimento sobre administração em enfermagem: Análise de um periódico (Mestre em Enfermagem)Escola de Enfermagem, Universidade de São, Paulo, 2004.

LOURENÇO, M. R., Desenvolvimento da competência em liderança na efectividade de organizações de saúde dirigidas por enfermeiros-gerentes. 2004. Dissertação (Doutorado em enfermagem) - Escola de Enfermagem, Universidade de São Paulo, São Paulo, 2004. 
LOURENÇO, M. R., Líderes da enfermagem brasileira sua visão sobre a temática da liderança e sua percepção a respeito da relação liderança enfermagem. Revista Latinoamericana. Enfermagem, Ribeirão Preto, v.9, n. 3, p. 14-19, maio, 2001.

LUHMANN, N. y DE GIORGIO, R. Teoría de la sociedad. México: Triana, 1998.

LUIZ, M. V. A Enfermagem e o conhecimento dos conceitos de liderança, motivação, comunicação, e mudança. Acta Paul. Enfermagem, v. 2, n. 4, Brasil, 1989.

MANFREDI, M. La profesionalización de enfermería y la calidad de educación de enfermería. Memorias. In: Jornadas científicas cultural de aniversario, Centro Médico Nacional Siglo XXI. IMSS, 1997.

MARTÍNEZ, B. M. et al. Sociología de una profesión: el caso de enfermería. México: Nuevomar, 1998.

MARX, C. Contribução para a critica da economía política. 2 ed. Lisboa: Estampa, 1979.

MENDES, I. A. C. Convivendo e enfrentando situações de stress profissional. Revista Latino-americana. Enfermagem, Ribeirão Preto, v.9, n. 2, p. 1-5, março-abril, 2001.

MENDES, I. A.C. Enfoque humanístico à comunicação em enfermagem. São Paulo, Sarvier, 1994.

MENDENHALL, W; REINMUTH, J. E. Estadística para administración y economía. Califórnia: Wadsworth. International/Iberoamericana, 1981.

MERTON, K. R. On social structure and science. USA: University of Chicago Press, 1996.

MEXICO. SECRETARIA DE SALUD. Reglamento de la Ley General de Salud en Materia de Investigación para la salud, 1987.

*. Sistema Nacional de Salud. Cámara de Senadores, Informe, 1992.

*. SIARHE. Informe de la situación de enfermería en México, 1999a.

*. Plan Nacional de Salud 2001-2006, 2000a.

*. Coordinación General de los Institutos Nacionales de Salud, Diario Oficial, 2000b.

*. Programa Nacional de Salud. 2001-2006, 2001a.

*. Catalogo de Beneficios Médicos (CABEME) Diario Oficial, 2003a.

*.Programa del Seguro Popular, 2006a. No.17, 2003b.

*. Comisión Interinstitucional de Enfermería (COIE). Minuta de la reunión ordinaria *. Plan rector de enfermería 2001 - 2006, 2001 b. 
*. Código de Bioética para el personal de salud, 2002.

MÉXICO. SECRETARÍA DE SALUD DISTRITO FEDERAL, (SSDF) Ley de salud, $2001 \mathrm{c}$.

*. Gobierno Distrito Federal, Anuario Estadístico 2006b

MÉXICO. INSTITUTO NACIONAL DE ESTADISTICA GEOGRAFIA E INFORMATICA (INEGI). Anuario Estadístico, 1998a.

*.Anuario Estadístico, 1999b.

*. Gobierno del Distrito Federal Anuario Estadístico, 1998b.

MINAYO, M: C. O desafio do conhecimento: Pesquisa qualitativa em saúde. 7. ed. Rio de Janeiro: Hucitec-Abrasco, 2000.

MINAYO, M: C. et al. Pesquisa social. Teoria, método e criatividade. 23. ed. Petrópolis: Vozes, 1994.

MIGUÉLEZ, M. M. Ciência y arte em la metodologia cualitativa. México: Trillas, 2004.

MINTZBERG, M. C. El proceso de la planificación estratégica. México: Mc Graw-hil, 2004.

MORENO F. G. Diseño y verificación de un modelo de sistemas para diagnosticar el equilibrio interno de las organizaciones. 2003. Disertación (doctorado en administración de las organizaciones). Facultad de Contaduría y Administración, Universidad Nacional Autónoma de México, Ciudad de México, Distrito Federal, 2003.

MORENO F. G. Conducta tipo A y la efectividad en las organizaciones. Trabajo para examen de oposición. Facultad de Contaduría y Administración. México: UNAM, 2005.

MORIN, E. El método 6 ed. Madrid, España: Cátedra, 2001.

MOTTA, P. R. Gestão contemporânea: A ciência e a arte de ser dirigente 9 ed. São Paulo: Record, 1998.

MOTA, P. R.; VASCONCELOS, I. F. G. Teoria geral da administração. São Paulo: Pioneira Thonson Learning, 2002.

MOUZELIS, N. P.; WEBER, M. As políticas sociology en organization and bureaucracy. Chicago: Aldene publishing Co, 1968.

NAJERA, N. R.M. et al. Situación de las escuelas de enfermería: tendencias de la investigación sobre la práctica en enfermería en México, México: UAM Xochimilco, 1988.

*. Recomendaciones de operación de campos clínicos para el desarrollo de actividades de enseñanza-aprendizaje de enfermería México: SS, 1990. 
*.Tendencias de la investigación sobre la práctica en enfermería en México. México: UAM-Xochimilco, 1992a.

* Estudio diacrónico, sincronico y prospectivo de la enfermería en México. México: UAM Xochimilco, $1992 b$.

NOGUEZ, A. ¿Cobertura para todos?. México: BBC Mundo, Periódico, 2006.

NIGHTINGALE, F. Notas sobre enfermería. Barcelona: Salvat, 1990.

OMS. Estrategia mundial de la salud para todos en el año 2000. Ginebra, 1981. Serie salud para todos No. 3 .

PAGANINI, P. La garantía de calidad, Acreditación de hospitales para América Latina y el Caribe. Ginebra: OPS/OMS, HSD/SILOS-13, 1999.

PASQUALI, L. Instrumentos Psicológicos: Manual prático de elaboração. Brasília: LabPAM, 1999.

PÉREZ LOREDO, P. L. Efemérides de enfermería. 1900-1985. México: Porrúa, 1986.

PÉREZ, M. J. Ciudad más grande del mundo, Historia de la Ciudad de México: Purrua, 2003.

PERROW, C. Sociología de las organizaciones.3 ed. España: Mc Graw Hill, 1998.

PETERS, T. La esencia liderazgo. Inspira libera consigue. Madrid: Pearson Prentice Hall, 2005.

QUEENDOM, H. Test Developer by Queendom. 2005. Disponible en: www.queendom.com/articles. htm. accesado en: 3 mayo, 2005.

RABAGO, J. Papel de la partera en los hospitales públicos. En Seminario de educación en enfermería. Hidalgo, México, 1954.

RUIZ DE ESPARZA. J. Niveles de atención médica. México: La Prensa Médica Mexicana, 1984.

SANTOS, N. M. F. Clima organizacional; pesquisa e diagnóstico. São Paulo: Stiliano, 1999.

SCHEIN, E. Aprendizaje organizacional. Madrid: Pearson Prentice Hall, 1982.

SENGE, P. La quinta disciplina. El arte y la práctica de la organización abierta al aprendizaje. México: Granica, 1990.

SIMÓN L. D. y KERTSZ, R. Organizaciones estresadas. España: Diario 5 días, 2003 
SIMÕES, A. L. A. Desenvolver o potencial de liderança: um desafio para o enfermeiro. 2001. Dissertação (Doutorado em enfermagem). Escola de Enfermagem, Ribeirão Preto, Universidade de São Paulo, São Paulo, 2001.

SIMÕES, A. L. \& FÁVERO, A. L. A., Aprendizagem da liderança: Opinião de enfermeiros sobre a formação acadêmica. Revista Latino-americana. Enfermagem, Ribeirão Preto, v. 8, n. 3, p. 91-96, julho, 2000.

SOBERÓN, A. G. Hacia un Sistema Nacional de Salud. México: Comisión de salud y seguridad social, 1983a.

*. Planteamientos iniciales para la consolidación de un Sistema Nacional de Salud. México: Acta Constitutiva Instalación de Gabinete de Salud. 1983b.

STANFORD, H. D. Authoritarism and leadership. Philadelphia: Institute for research in human relation, 1950.

TANNENBAUM, I. et al. Liderança e organização. São Paulo: ATLAS, 1970.

TAYLOR, F. Princípios de administración. México: Herrero Hermanos, 2000.

THOMPSON.V. Moderna organização. Rio de janeiro: Freitas Bastos, 2002.

TORRES S. J. R. y MARTÍNEZ, G.; J, V. The Entrepreneurs and the conduct type "A". Magazine Enterprising. México: UNAM, 1999.

TORRES S. J. R. El estilo de dirección y la conducta tipo A en el directivo mexicano del sector financiero. XXX Asamblea. São Paulo: CLADEA, 1995.

TRIVIÑOS, A. N.S, Introdução à pesquisa em ciências sociais: A pesquisa qualitativa em educação. São Paulo: Atlas, 1987.

TREVIZAN M. A. Enfermagem hospitalar. Administração burocracia. Brasília: Universidade de Brasília, 1988.

TREVIZAN M. A. et al. Liderança e comunicação no cenário da gestão em enfermagem Revevista Latino- americana. Enfermagem, Ribeirão Preto, v. 6, n. 5, p. 77-82, dezembro, 1998.

VILLALOBOS, M. M. D. El desarrollo del liderazgo y la educación en enfermería. Revista Educación Medica y Salud, Washington, v. 22, n. 2, p. 191-199, 1988.

WEBER, M. Os três aspectos da autoridade de legítima. Organizaciones complejas en Amitai Etzioni, Sao Paulo: Atlas, 1965.

WEBER, M. El político y el científico. México: Pórrua, 1998.

¿Qué es la burocracia? México: Coyoacan, 2005. 
WEATHERALL, J. Crisis de comunicación. The lost of healing. Brasil: Latino Americana, 1997.

WORLD HEALTH ORGANIZATION, Reunion. Health for all leadership initiative. Geneva: The Report of WHO/HLD/87.2, 1987.

*. Health for all Leadership Initiative. A Report of activities implemented during Geneva: Reunion 1985- 1986. WHO/HLD/87.3, 1987.

*. Forty- first World Health Assembly. Health for all Leadership Initiative. Geneva: A Report of the technical Discussions: Main Recommendations and conclusions, 1988.

WHEATLEY, M. Liderazgo y nueva ciencia. Argentina: Barret, Koheler Publishers, Inc, 1992.

YANEZ, E. Diseño médico arquitetônico de hospitales. México: Siglo XXI, 2003. 


\section{APENDICE A}

UNIVERSIDADE DE SÃO PAULO

ESCOLA DE ENFERMAGEM DE RIBEIRÃO PRETO, BRASIL

\section{QUESTIONÁRIO DE ESTILOS DE LIDERANÇA}

Este questionário permitirá identificar as percepções que você tem sob os estilos de liderança que se exerce em sua organização.

Observações: os dados que você manifeste são anônimos e confidenciais e só serão utilizados pela pesquisadora com fines acadêmicos.

\section{A. DADOS PESSOAIS}

Por favor, nas seguintes situações escolha uma opção fazendo um círculo na letra correspondente.

\begin{tabular}{|ll|}
\hline 1. Cargo que ocupa & a. Coordenadora \\
& b. Diretora \\
& c. Sub diretora \\
& d. Diretora \\
& e. Supervisora \\
\hline
\end{tabular}

\begin{tabular}{|c|c|}
\hline 2. ¿Direção e lide & \\
\hline são diferentes na & a. $\mathrm{Sim}$ \\
\hline prática? & b. Não \\
\hline
\end{tabular}

\begin{tabular}{|l|l|}
\hline 3. Sexo & $\begin{array}{l}\text { a. F } \\
\text { b. M }\end{array}$ \\
\hline
\end{tabular}

\begin{tabular}{|l|c|}
\hline 4. Tempo no cargo & Anos \\
\hline
\end{tabular}

5. Horas diárias que o seu cargo requere

6. Número de enfermeiras que sob sua direção

\begin{tabular}{|l|l|l|}
\hline 7. Escolaridade & a. Ensino fundamental & \\
& b. Técnico em & \\
enfermagem & c. Universitário & \\
& d. Pós-graduação & \\
\hline
\end{tabular}




\section{B. ALTERNATIVAS DE DECISÃO}

Por favor, nas seguintes situações escolha uma opção fazendo um círculo na letra correspondente.

1. Se lhe consta que o pessoal de enfermagem está cumprindo satisfatoriamente com seus deveres:

\begin{tabular}{|l|l|}
\hline A & Interviria somente se algo extraordinário acontecesse. \\
\hline B & Faria controles periódicos para ter garantia de que tudo corre bem. \\
\hline C & Procuraria ter a garantia de que tudo corre bem intensificando os controles. \\
\hline D & Delegaria à equipe a função de controle do que é realizado. \\
\hline
\end{tabular}

2. Se você designa um paciente a uma enfermaria e lhe explica claramente o cuidado a ser realizado, mas o paciente se queixa do atendimento recebido:

\begin{tabular}{|l|l|}
\hline A & $\begin{array}{l}\text { Escutaria a explicação da enfermeira, mas lhe pediria para que isso não volte } \\
\text { acontecer. }\end{array}$ \\
\hline B & Pediria à enfermeira fazer novamente sua tarefa, mas sob sua supervisão. \\
\hline C & $\begin{array}{l}\text { Comentaria com a enfermeira o acontecido e recomendaria mais cuidado em ações } \\
\text { futuras. }\end{array}$ \\
\hline D & $\begin{array}{l}\text { Falaria com a enfermeira para, de maneira que, ambas procurem uma solução ao } \\
\text { problema. }\end{array}$ \\
\hline
\end{tabular}

3. O grupo de trabalhadores sob sua responsabilidade trabalharia com espírito de equipe, até cobriria voluntariamente às ausências e atrasos dos seus companheiros. Devido a problemas de tráfego, a autoridade iniciou horários flexíveis, isto é, entrar cedo e sair cedo ou entrar tarde e sair tarde:

\begin{tabular}{|l|l|}
\hline A & $\begin{array}{l}\text { Permitiria que as enfermeiras adotassem essa conduta sempre que isso não interferisse } \\
\text { no trabalho. }\end{array}$ \\
\hline B & Decidiria quem pode usar o horário flexível. \\
\hline C & $\begin{array}{l}\text { Faria uma reunião para discutir, com as enfermeiras, o que seria mais conveniente em } \\
\text { relação ao horário. }\end{array}$ \\
\hline D & $\begin{array}{l}\text { Enviaria uma circular ao pessoal de enfermagem notificando-lhe que não haverá } \\
\text { flexibilidade de horário. }\end{array}$ \\
\hline
\end{tabular}

4. Há um mês que você recebeu uma nova supervisora e ela não está fazendo o trabalho como você esperava que fosse realizado após um mês de treinamento:

\begin{tabular}{|l|l|}
\hline A & Explicaria claramente o que ela deveria fazer e observaria a sua forma de trabalhar. \\
\hline B & Dir-lhe-ia que seu treinamento estava concluído e que deveria ter maior iniciativa. \\
\hline C & A animaria a ter mais confiança em suas ações e suas capacidades. \\
\hline D & Supervisionaria diretamente o trabalho da supervisora. \\
\hline
\end{tabular}


5. Uma chefe de especialidade com um excelente rendimento durante os dois últimos anos, recentemente, teve um problema familiar e diminuiu a qualidade e o rendimento do seu trabalho.

\begin{tabular}{|l|l|}
\hline A & Falaria com ela tentando que voltasse ao seu anterior estado de eficiência. \\
\hline B & A ajudaria a compreender que o seu problema pessoal está afetando seu trabalho. \\
\hline C & $\begin{array}{l}\text { Conversaria com a chefe de especialidade para animá-la a superar o problema pelos } \\
\text { seus próprios meios. }\end{array}$ \\
\hline D & Recomendar-lhe-ia uma solução a chefe de andar e se asseguraria que a cumprisse. \\
\hline
\end{tabular}

6. Sua organização não permite fumar em certas áreas. Você viu a uma supervisora fumando em uma dessas áreas restringidas. Ela está na organização há 10 anos e durante todo esse tempo tem se mostrado muito responsável e nunca foi surpreendida fumando.

\begin{tabular}{|l|l|}
\hline A & Você conversaria com ela sobre o que estava fazendo e a deixaria ir. \\
\hline B & Perguntar-lhe-ia porque estava fumando e como pretendia remediar o acontecido. \\
\hline C & Dar-lhe-ia uma nova instrução sobre a proibição de fumar e a observaria no futuro. \\
\hline D & Exporia claramente o incidente, observaria a sua atitude e a observaria no futuro. \\
\hline
\end{tabular}

7. A equipe de trabalho do seu departamento usualmente trabalha bem em grupo, unidos e com pouca supervisão, mas recentemente houve um problema entre duas enfermeiras.

\begin{tabular}{|l|l|}
\hline A & $\begin{array}{l}\text { Chamaria às envolvidas para fazer-lhes entender que o seu conflito está afetando a } \\
\text { equipe e que estaria observando o comportamento delas. }\end{array}$ \\
\hline B & $\begin{array}{l}\text { Teria a necessidade de conhecer a origem do problema e pediria para que este fosse } \\
\text { resolvido. }\end{array}$ \\
\hline C & $\begin{array}{l}\text { Pediria para compreender que essa atitude poderia danificar a tranqüilidade do } \\
\text { ambiente de trabalho que sempre prevaleceu. }\end{array}$ \\
\hline D & $\begin{array}{l}\text { Faria uma reunião com as duas enfermeiras para que chegassem a uma solução e } \\
\text { realizaria uma supervisão mais de perto. }\end{array}$ \\
\hline
\end{tabular}

8. Uma das supervisoras ultimamente tem enxaqueca e ocasionalmente dor nas costas o qual a impede de fazer todo o seu trabalho, seus companheiros protestam porque sentem-se sobrecarregados assumindo o trabalho:

\begin{tabular}{|l|l|}
\hline A & Analisaria o problema e de acordo com a supervisora buscaria a solução. \\
\hline B & Incentivaria a supervisora a procurar ajuda especializada. \\
\hline C & $\begin{array}{l}\text { Diria à supervisora que esta causando constrangimento com os demais e que deve } \\
\text { resolver o problema. }\end{array}$ \\
\hline D & $\begin{array}{l}\text { Designaria à supervisora uma tarefa independente dos outros para que possa faltar } \\
\text { quando esta adoeça. }\end{array}$ \\
\hline
\end{tabular}


9. A enfermeira mais experiente e eficiente da sua equipe lhe trouxe uma proposta detalhada sobre a forma em que se poderia incrementar a produtividade de certas tarefas. Você acha que é uma excelente idéia:

\begin{tabular}{|l|l|}
\hline A & Analisaria com ela a forma de pôr em prática sua idéia. \\
\hline B & Daria alternativa para que a enfermeira possa implementar a sua proposta. \\
\hline C & $\begin{array}{l}\text { Dir-lhe-ia enfermeira para que continuasse com a sua proposta e que a mantivesse } \\
\text { informada. }\end{array}$ \\
\hline D & Solicitaria à enfermeira informá-la permanentemente sobre os avanços. \\
\hline
\end{tabular}

10. Sua chefe imediata lhe pediu um relatório especial. A supervisora de enfermagem administrativa tem todas as habilidades para desempenhar o trabalho, mas se irrita porque nunca fez um relatório deste tipo:

\begin{tabular}{|l|l|}
\hline a & $\begin{array}{l}\text { Diria à supervisora que ela tem as habilidades para esse trabalho e lhe ofereceria } \\
\text { indicações e supervisão. }\end{array}$ \\
\hline b & Daria à supervisora metodologia para elaborar o relatório. \\
\hline c & $\begin{array}{l}\text { Descreveria à supervisora os benefícios de fazer este trabalho, lhe daria idéias sobre a } \\
\text { forma de fazê-lo e verificaria o seu progresso. }\end{array}$ \\
\hline d & $\begin{array}{l}\text { Conversaria com a supervisora sobre as possíveis maneiras de fazer o relatório e a } \\
\text { apoiaria e estimularia. }\end{array}$ \\
\hline
\end{tabular}

11. Uma das melhores diretoras de seu departamento está encaminhando o relatório mensal com retraso e com erros. Você fica surpresa porque ela sempre foi muito eficiente:

\begin{tabular}{|l|l|}
\hline a & Examinaria seus relatórios passados e lhe explicaria claramente o que se espera de ela. \\
\hline b & $\begin{array}{l}\text { Programaria uma reunião mensal com ela para revisar o seu próximo relatório e fazer } \\
\text { as observações pertinentes. }\end{array}$ \\
\hline c & $\begin{array}{l}\text { Você lhe pediria para que o seu próximo relatório esteja pronto no tempo requerido e } \\
\text { sem erros. }\end{array}$ \\
\hline d & Analisaria com ela a razão do atraso e dos erros e juntas procurariam uma solução. \\
\hline
\end{tabular}

12. Seus trabalhadores são realmente efetivos e gostam de participar nas decisões. Um enfermeiro muito experiente foi contratado para implantar um novo método de trabalho:

\begin{tabular}{|l|l|}
\hline a & $\begin{array}{l}\text { Falaria com o grupo sobre o método do enfermeiro experiente e explicaria em que } \\
\text { consiste. }\end{array}$ \\
\hline b & Aplicaria o novo método e supervisaria de perto seu cumprimento. \\
\hline c & $\begin{array}{l}\text { Explicaria ao grupo o porquê da importância do novo método e explicaria os seus } \\
\text { benefícios. }\end{array}$ \\
\hline d & Nomearia um comitê para o estudo do método e o informara deste. \\
\hline
\end{tabular}


13. Uma das melhores chefes de andar lhe disse que está interessada em ser supervisora, você lhe disse que a ajudaria a preparar-se para uma promoção, mas que não garantia a sua promoção.

\begin{tabular}{|l|l|}
\hline $\mathrm{a}$ & Delegar-lhe-ia funções administrativas e supervisaria a seu trabalho. \\
\hline $\mathrm{b}$ & Permitir-lhe-ia escolher suas próprias funções administrativas. \\
\hline c & Apoiaria seus esforços em quanto supervisionaria a sua atuação. \\
\hline d & $\begin{array}{l}\text { Conversaria com ela sobre suas próximas funções administrativas e a forma de } \\
\text { executá-las. }\end{array}$ \\
\hline
\end{tabular}

14. Você somente convida a expertos para expor temas relacionados com o trabalho da sua equipe e ultimamente alguns membros da sua equipe tem aparecido sem serem convidados.

\begin{tabular}{|l|l|}
\hline a & $\begin{array}{l}\text { Dirigiria formalmente a reunião e deixaria que além dos convidados as não } \\
\text { convidados opinassem livremente sobre a tema. }\end{array}$ \\
\hline b & Permitiria ao grupo organizar as intervenções na reunião. \\
\hline c & $\begin{array}{l}\text { Solicitaria ao grupo que apresentasse suas intervenções antecipadamente para decidir } \\
\text { quais seriam aceitos. }\end{array}$ \\
\hline d & Faria uma reunião para entrar em acordo sobre as regras das reuniões. \\
\hline
\end{tabular}

15. A direção do departamento de enfermagem cumpre normalmente com o seu dever, mas neste mês, eles têm um problema de atraso.

\begin{tabular}{|l|l|}
\hline a & $\begin{array}{l}\text { Conversaria com o grupo e faria sugestões sobre al forma de melhorar o ritmo de } \\
\text { produção. }\end{array}$ \\
\hline b & Reprogramaria o trabalho tentando incorporar as ideais do grupo. \\
\hline c & $\begin{array}{l}\text { Lembraria ao grupo que estas atuados e seria necessário a reprogração do } \\
\text { cumprimento das tarefas. }\end{array}$ \\
\hline d & $\begin{array}{l}\text { Supervisionaria restritamente o desempenho do grupo para garantir o cumprimento das } \\
\text { tarefas. }\end{array}$ \\
\hline
\end{tabular}

16. O melhor chefe do andar recentemente cometeu certos erros no seu trabalho.

\begin{tabular}{|l|l|}
\hline a & Analisaria a problema com a diretora do andar e lhe permitiria resolver seu problema. \\
\hline b & Pediria ao diretor do andar que encontrasse a forma de não cometer mais erros. \\
\hline c & Não faria nada e diria ao diretor do andar suficiente tempo para melhorar seu trabalho. \\
\hline d & Falaria com ela sobre as cousas do problema e sua solução. \\
\hline
\end{tabular}

FUENTE: CHUNG, H. K.; SCHMIESING, M. O.; LUSSIES, N. R. Management critical succes factors. Study guide with experimental exercises. Allyn an Bacon Inc. Boston, 1987. 


\section{APENDICE B}

UNIVERSIDADE DE SÃO PAULO

ESCOLA DE ENFERMAGEM DE RIBEIRÃO PRETO, BRASIL

\section{QUESTIONÁRIO DE MATURIDADE DOS SEGUIDORES}

Este instrumento permite identificar a opinião do líder em relação à maturidade de seus seguidores.

Por favor, nos seguintes pontos escolha uma opção e marque com um círculo a letra que corresponda a sua eleição.

\section{Quando a equipe realiza alguma tarefa:}

a. É responsável e está orientado para os resultados.

b. Preocupa-se mais com o resultado final que com os logros obtidos no processo.

c. Finaliza o trabalho com demora.

d. Entende a tarefa como uma forma de castigo.

\section{Quando a equipe realiza suas tarefas:}

a. Mostra habilidade moderada, mas pouca disposição.

b. Não desenvolve a tarefa de maneira aceitável.

c. Utiliza os recursos eficientemente..

d. Interpreta a tarefa como exigência.

3. Quando a equipe se enfrenta a novas tarefas:

a. Periodicamente informa ao chefe sobre o progresso das tarefas.

b. Escuta atenciosamente as instruções.

c. Mostram conhecimento, mas pouca disposição.

d. Evita realizar a tarefa transferindo-a a outro membro da equipe.

\section{Quando a equipe aprende novos procedimentos:}
a. Responde automaticamente "sim eu sei".
b. Comparte ideáis creativas.
c. Pergunta constantemente sobre a tarefa, mostrando interesse.
d. Freqüentemente solicita maiores informações.

\section{Quando a equipe se enfrenta a tarefas difíceis:}
a. Sofre bloqueios por estresse.
b. Sente-se cansado ou sobrecarregado.
c. Supera as situações estressantes.
d. Mostra-se ansioso ou excitado.

\section{Quando a equipe é requerida para uma tarefa adicional:}
a. É cuidadoso com o cumprimento das regras e das instruções.
b. Sente-se indispensável.
c. É receptivo às sugestões, mas demora para captá-las.
d. Sente intensa sobre carga de trabalho. 
7. Durante a realização de uma tarefa a equipe:
a. Limita-se a realizar o estritamente necessário.
b. Mostra disposição para ajudar aos demais integrante na tomada de decisões.
c. Compromete emocionalmente ao líder.
d. É conflituoso no cumprimento da tarefa.

8. Quando é realizado trabalho em equipo os integrantes do grupo:
a. Mostram dificuldade para ajudar aos demais.
b. Mostram-se à defensiva e queixoso.
c. Suprem as deficiências aleijas.
d. Mostram-se conformista e apático.

9. Quando os membros a equipe executa uma tarefa mostram-se:
a. Com necessidade de reatroalimentação das informações.
b. Interessado em seu beneficio pessoal.
c. Orientado aos resultados.
d. Desinteressado pelos resultados.

10. Quando a equipe trabalha somente mostra-se:
a. Confuso e desorientado.
b. Responsável e orientado para os resultados.
c. Sem experiência e inseguro.
d. Impaciente por terminar e dar o seguinte passo.

11. Quando a equipe se prepara para realizar uma tarefa:
a. O comportamento é confuso.
b. Questiona sua própria habilidade.
c. Aceita as tarefas sem suficiente informação.
d. Decide corretamente em função da tarefa.

12. Quando a equipe realiza uma tarefa especial:
a. Trabalha com autonomia e segurança.
b. Sua expressão corporal é depressiva e submissa.
c. Atua com rapidez.
d. Procura ajuda/apoio.

13. Quando é solicitado trabalhar em equipe:
a. Comparte livremente informação sobre a tarefa.
b. Mostra atitude defensiva.
c. Fala com rapidez e intensidade.
d. Cala frente ao erro.

14. Quando é pedida uma opinião à equipe de trabalho sobre uma tarefa:
a. Mostra-se entusiasta expositor.
b. Focaliza problemas potenciais.
c. Mostra-se intimidado.
d. Comparte as boas e más noticias. 
15. Quando a equipe erra em alguma tarefa:
a. Justificam-se de forma enérgica.
b. Responde às perguntas de maneira superficial.
c. É assertivo em suas explicações.
d. Oferece explicações não solicitadas.

16. Os membros da equipe realizam melhor sua tarefa quando:
a. Trabalha em equipe.
b. Recebe apoio dos companheiros.
c. Pede apoio aos demais.
d. Sente-se acompanhado.

FUENTE: HERSEY, P. and BLANCHARD, K. Lead self Instrument and the directions for self Scoring and Analysis. Copyright, 1973. Center for Leadership studies. p. 259. 


\section{APÊNDICE C}

UNIVERSIDADE DE SÃO PAULO

ESCOLA DE ENFERMAGEM DE RIBEIRÃO PRETO, BRASIL

\section{QUESTIONARIO TRAÇOS DE CONDUTA TIPO A DO DIRETIVO}

Instrumento para identificação características de conduta, segundo a teoria de Friedman e Rosenman, dos diretivos de enfermagem.

Instrução: As seguintes declarações descrevem um comportamento. Por favor avalie e escolha a resposta que mais se ajuste a seu forma de ser, e marque com uma $\mathrm{X}$ a resposta na coluna respectiva.

\begin{tabular}{|c|c|c|c|c|c|}
\hline & DECLARAÇÃO & $\begin{array}{c}1 \\
\text { Nunca }\end{array}$ & $\begin{array}{c}2 \\
\text { Raras } \\
\text { vezes }\end{array}$ & \begin{tabular}{|c|} 
\\
\\
Quase \\
sempre
\end{tabular} & $\begin{array}{c}4 \\
\text { Sempre }\end{array}$ \\
\hline 1 & $\begin{array}{l}\text { Acha que o dia não tem suficientes horas para todas as } \\
\text { coisas que precisa fazer. }\end{array}$ & & & & \\
\hline 2 & Mobiliza-se, caminha ou come com rapidez. & & & & \\
\hline 3 & $\begin{array}{l}\text { Sente-se impaciente em relação ao ritmo lento em que } \\
\text { se desenvolvem os acontecimentos. }\end{array}$ & & & & \\
\hline 4 & $\begin{array}{l}\text { Costuma interromper o seu interlocutor quando lhe } \\
\text { parece que está falando demais. }\end{array}$ & & & & \\
\hline 5 & Tende a terminar as frases de outras pessoas. & & & & \\
\hline 6 & $\begin{array}{l}\text { Sente-se exageradamente irritado (a) quando o carro } \\
\text { que vai a sua frente, no seu conceito, vai a baixa } \\
\text { velocidade. }\end{array}$ & & & & \\
\hline 7 & $\begin{array}{l}\text { Considera angustiante a necessidade de fazer fila ou } \\
\text { esperar sua vez para conseguir uma mesa em um } \\
\text { restaurante ou ser atendido no banco. }\end{array}$ & & & & \\
\hline 8 & $\begin{array}{l}\text { Encontra intolerável observar como outras pessoas } \\
\text { realizam tarefas que você acredita fazer com maior } \\
\text { rapidez. }\end{array}$ & & & & \\
\hline 9 & $\begin{array}{l}\text { Fica impaciente quando tem a obrigação de realizar } \\
\text { tarefas repetidas. }\end{array}$ & & & & \\
\hline 10 & $\begin{array}{l}\text { Você é das pessoas que tentam sempre conseguir } \\
\text { resumos de obras que lhe interessam. }\end{array}$ & & & & \\
\hline 11 & $\begin{array}{l}\text { Esforça-se por pensar ou fazer duas ou mais coisas ao } \\
\text { mesmo tempo. }\end{array}$ & & & & \\
\hline 12 & $\begin{array}{l}\text { Durante seus momentos de descanso, continua } \\
\text { pensando em seus problemas profissionais, domésticos } \\
\text { ou de trabalho. }\end{array}$ & & & & \\
\hline
\end{tabular}




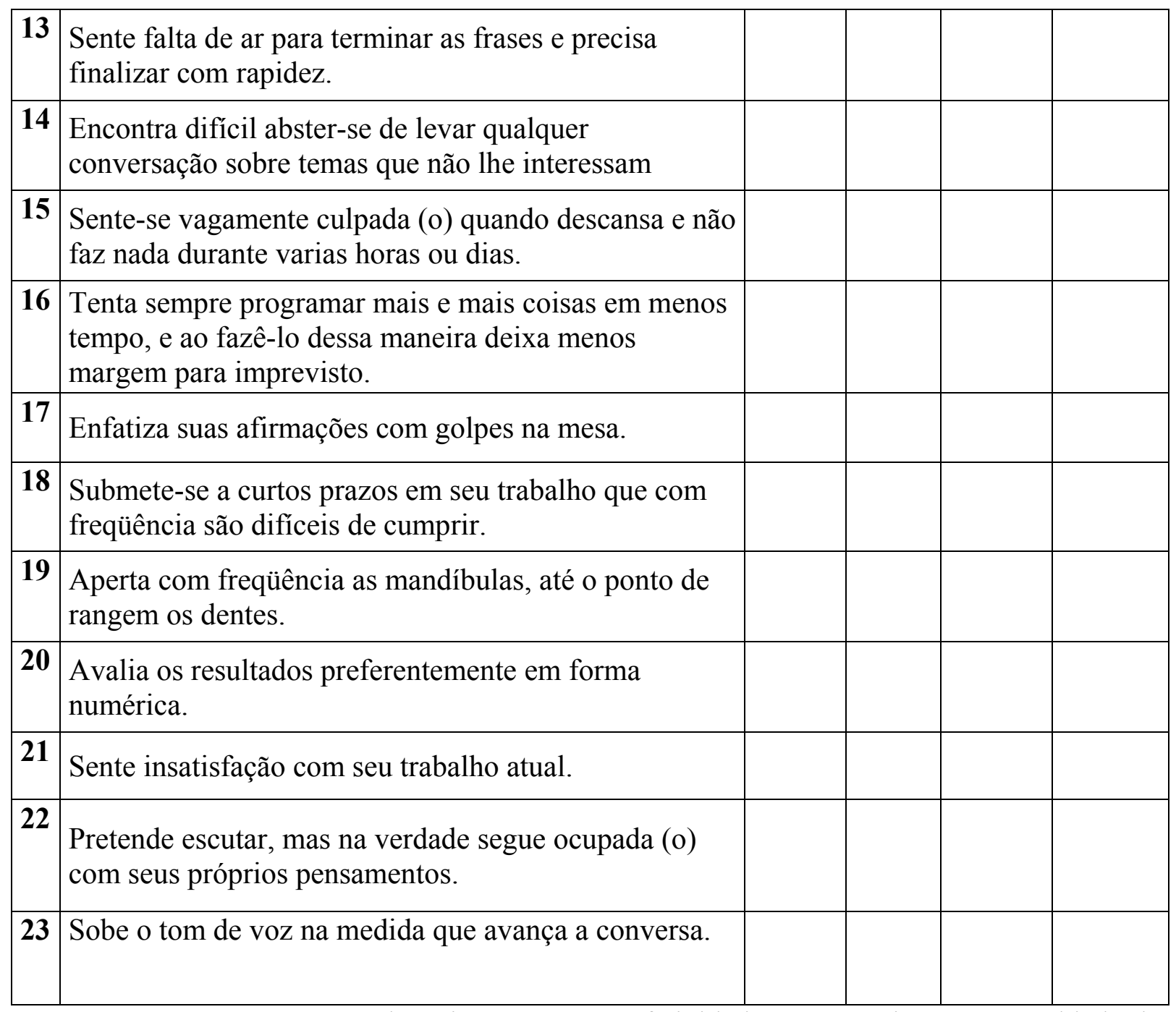

Fonte: MORENO, F. G. Conduta tipo A e B e a efetividade nas organizações. Faculdade de Contabilidade e Administração. UNAM, México, 2005. 


\section{APENDICE D}

UNIVERSIDADE DE SÃO PAULO

ESCOLA DE ENFERMAGEM DE RIBEIRÃO PRETO, BRASIL

\section{ENTREVISTA SEMI-ESTRUTURADA}

Os dados solicitados são importantes para possibilitar a análise das diferentes percepções do ambiente de trabalho onde desempenha as funções como dirigente.

\section{Dados de Identificação}

1). Nível de escolaridade

2). Estado civil

3). Sexo

4). Tempo de permanência no posto atual

5). Número de camas que tem este hospital

6). Número de membros da equipe de enfermagem a seu cargo

7). Nome do cargo do qual você depende

8). Horas diárias exigidas para o cumprimento do cargo

\section{PERGUNTAS NORTEADORAS}

Objetivo: Identificar a percepção que tem o diretivo com relação ao estilo de liderança, cumprimento de tarefas de seus seguidores e ambiente de trabalho nas organizações de saúde onde exerce seu trabalho.

1). Como você define a liderança?

2). Na sua percepção, que estilo de liderança oferece melhor êxito para você?

3). Na sua perspectiva, que conceito você tem dos membros da sua equipe em relação a suas fortalezas e debilidades no desempenho?

4). Na sua percepção, como o ambiente de trabalho das organizações hospitalares da Secretaria de Saúde do Distrito Federal repercute em você? 


\section{APENCIDE E TERMO DE CONSENTIMENTO LIVRE E ESCLARECIDO}

Estamos desenvolvendo um estudo intitulado: "Liderança da enfermagem nas organizações de saúde da cidade de México, Distrito Federal".

Os objetivos da pesquisa são:

a). Identificar os estilos de liderança: instrutivo (S1), persuasivo (S2), participativo (S3) e delegativo (S4), segundo o modelo de Hersey e Blanchard, percebido pelos enfermeiros com cargos diretivos dos hospitais da Secretaria de saúde, localizados na Cidade de México, Distrito Federal.

b). Identificar, segundo o modelo de Hersey e Blanchard, a percepção dos diretivos de enfermagem em relação aos graus de maturidade (inativo - R1, reativo - R2, préativo - R3 e interativo -R4) de seus colaboradores.

c). Identificar os traços de conduta tipo A (C) dos diretivos de enfermagem dos hospitais gerais da Secretaria de Saúde, localizados na cidade de México, Distrito Federal.

Por esta razão, desejamos conhecer, com base em sua experiência, sua percepção em relação à liderança que você exerce nesta organização hospitalar, onde você exerce um cargo diretivo.

Será realizada uma entrevista com horário marcado e em acordo com sua agenda de trabalho. Você poderá decidir o dia e a hora da entrevista, cuja duração não será superior a uma hora. Para tanto, lhe informamos que será necessário gravar a entrevista em fita cassete. A entrevista será realizada no seu local de trabalho, no lugar onde você se sinta mais cômoda (o) e serão respondidas todas suas dúvidas relacionadas com o estudo.

O presente estudo conta com a avaliação e aprovação do Comitê de Bioética da Faculdade de Enfermagem e Obstetrícia da Universidade de Guanjuato, México e as atividades, no seu local de trabalho serão iniciadas após receber a autorizado dos diretivos de esta instituição.

Sua identificação será mantida em sigilo, pode sentir-se livre de expressar suas opiniões com liberdade, os dados serão manejados com confidencialidade e manipulados unicamente pela investigadora. Sua participação será anônima.

Pelo exposto, ACEITO participar no estudo. Tenho conhecimento da minha participação e responsabilidade e dou meu consentimento para ser entrevistada por Maria Alberta García Jiménez, aluna do Programa de Pós-Graduação em Enfermagem Fundamental do departamento de Enfermagem Geral e Especializada da Escola de Enfermagem de Ribeirão Preto, Universidade de São Paulo - Brasil. 


\section{ACEITO}

Participante

Nome:

Pesquisadora:

María Alberta García Jiménez

Domicilio: Periférico sur 7666 casa 518 Col. Rinconada Villa Coapa, Delegación Tlalpan D. F. México. Teléfono: 55946591 Casa, oficina 54837233
Assinatura

Assinatura: 


\section{APENDICE F}

\section{RESPUESTAS SE ENTREVISTA SEMI-ESTRUCTURADA}

\section{PREGUNTAS NORTEADORAS}

Objetivo: Identificar la opinión que tiene el directivo en relación al estilo de liderazgo, cumplimiento de tareas de sus seguidores y ambiente laboral en las organizaciones de salud donde ejerce su trabajo.

\section{1). ¿Cómo define usted el liderazgo?}

a) El liderazgo lo considero que es servicio, es la capacidad de servir t también de ayudar a conducir a grupos pero sobre todo es un alto compromiso de servicio.

b) El liderazgo yo lo percibo muy paternalista se trata de satisfacer a todas las personas sin medir las consecuencias de prestaciones, que repercuten al final de todo en el trabajo.

c) Bueno pues hay dos tipos de liderazgo el nato y el que se ejerce a través del cargo que se tiene. El liderazgo puede ser la persona que lidera a un grupo de compañeras de enfermería en este caso.

d) El liderazgo es dependiendo de cada institución y de cada situación particular con el personal que se ejerce, hay diferentes tipos de liderazgo estos liderazgos van dependiendo de la organización institucional y del personal con el que uno esta conviviendo.

e) Es la manera de actuar ante ciertas situaciones que se presentan y resolver problemas. Es el privilegio que tiene una persona de saber mandar y hacerse obedecer y que tiene poder para hacerlo.

f) El liderazgo para mi es una parte importante de la administración de cualquier organización donde debe haber un líder, con ese liderazgo se puede dirigir, organizar todos los servicios desde la jefatura, todas tenemos algo de líder tenemos que usarlo para todos los servicios y en todos los turno. El liderazgo es la base del éxito de la organización de enfermería.

g) El liderazgo es un conjunto de atributos que tienen algunas personas y con ellos convences a un grupo de personar que se convierte en sus líderes y el grupo en sus seguidores para lograr un fin común.

h) El liderazgo yo concibo, como esa capacidad de las personas o de una institución de poder llevar la delantera, ser cabeza de grupo o de todo un hospital, si yo creo que la forma amplia es tener la facultad de ser ese guía, esa guía de manera pudiera ser natural que ejerza alguna persona a una institución. 


\section{2). ¿En su percepción que estilo de liderazgo le ofrece mejor éxito a usted?}

a) Depende al tipo de grupo con el que se enfrenta uno, porque se manejan grupos muy heterogéneos y cada grupo tiene diferentes necesidades, uno se tiene que ubicar a las necesidades del grupo y de persona por persona o sea de manera individual y no todas son iguales y uno va cambiando de actitud para cada grupo o persona para manejar o no perdón, de conducir, yo creo que el líder tiene que adaptarse a las circunstancias del grupo que en ese omento esta conduciendo, ese es el liderazgo que mejor éxito he tenido. El tipo de liderazgo que más me satisface es el trato con el ser humano porque puedo tratar a las personas como seres humanos los trato de ayudar como individuos más que como trabajadores de la institución las personas no son mías por lo que las trato con respeto, porque yo soy una trabajadora más de la institución que estamos atendiendo para el cuidado del paciente, los programas que existen van encaminados al ambiente laboral que deben ser percibidos desde el aspecto humano del trabajador, desde como llegan, a mi me gusta platicar mucho con ellos de repente te das cuenta que alguien esta faltando mucho tu solo ves el resultado pero no sabes el porque de su conducta, cuando exploras sabes que tiene un hijo enfermo, la mamá enferma, el papá que esta enfermo que se esta muriendo todo esto se proyecta en el ambiente laboral y entonces yo trato de ir con ellos platicar y poderlos ayudar en la medida de lo posible incluso con descansos, de vacaciones etc. para que ellos se sientan mejor. Considero que la parte emocional del trabajador se va a proyectar en su rendimiento. El liderazgo que mas me ha dado satisfacción es el rotativo (situacional) siempre y cuando no sea el autoritario pues primero no va con mi persona y segundo no me funciona con la gente, sin embargo a veces lo aplico porque hay personas muy dificiles y solo entienden cuando se les ordenan las cosas, no les puedes consultar algo. Porque siempre te van a contestar con evasivas o pedir cosas, algunos actúan como niños porque el hombre por naturaleza es insatisfecho de manera general. El liderazgo rotativo o delegatorio coincido totalmente así como el instructor.

b) El estilo de liderazgo que me satisface es cuando mezclo diferentes estilos según sea el caso de cada persona o grupo, en donde las decisiones se toman en función del trabajo para beneficio de los pacientes.

c) El nato puesto que ya tengo 23 años de ser jefe y eso ya dice algo. Considero que es demócrata ya que todas las personas participan.

d) El liderazgo situacional precisamente porque depende del tipo de gente que se trate, es el grado que se ejerce. El liderazgo definitivamente como lo mencione anteriormente se define más que nada de acuerdo a la situación que se esta viviendo y se requiere para manejar al personal.

e) Pues yo digo que es el democrático es positivo, mucha gente podría pensar que fuera autoritario. Creo que aquí todas las autoridades tratamos de ser demócratas. Esta forma de tratar al personal me ha funcionado, hay problemas pero creo que en ninguna organización se acaban, son parte de la vida y de la dinámica de la sociedad.

f) Bueno aqui en el hospital yo considero a mi criterio que desarrollamos, estilos combinados, los combinados por que para diferentes personas se usa diferentes estilos de liderazgo para lograr persuadirlo. A veces quieres un tipo de liderazgo pero no puedes hacerlo, por que la ley interna del hospital nos marca el tipo de liderazgo y tienes que hacerlo por que así nos marca el reglamento y lo tienes que hacer. Si es dificil para la gente. 
Hubo cambios de política de lo que no estábamos acostumbrados a trabajar, ha sido dificil para todos estos cambios y la creación de normas. Yo les digo vamos a conocer desde la norma más sencilla entre comillas por que no hay nada sencillo. Pero yo en ese hospital combino los diferentes tipos de liderazgo de acuerdo a la personalidad de las enfermeras, de acuerdo al momento.

g) El liderazgo, el que yo ejerzo en este momento, yo lo considero democrático, por que finalmente me da buenos resultados, pues no me gusta ser impositiva, hay cosas en las que si uno tiene que decidir se hace esto por esta situación pero hay otras en las que yo solicito la opinión tanto de supervisión como de jefes de servicio, para que finalmente lleguemos a un acuerdo y todas estamos comprometidas por que a veces es eso que no ha compromiso, por no tomarlas en cuenta, por que si uno se los dice como una indicación o una orden no nos comprometemos. Entonces mi estilo es democrático.

h) El liderazgo situacional, pues uno tiene que adaptar los estilos según sea la persona o el grupo que se dirige pues cada ser humano es único diferente luego no puedo ser de igual estilo para todos.

\section{3). ¿Desde su perspectiva que concepto tiene de su personal profesional en relación a sus fortaleza y debilidades?}

a) Las fortalezas de mi personal es en general profesional, comprometido disciplinado y que tiene muchos deseos de superación, no solamente por el incentivo económico sino por el desarrollo profesional, buscan seguir estudiando, hacer post grados esto es muy gratificante. Son críticos y consultivos. Además tengo muchos egresados de la UAM Xochimilco. Las debilidades que detecto en algunos, es que a veces se comportan con cierta inmadurez como ejemplo comentan que porque él si y yo no, hay conflictos por interese personales, otra debilidad es la intolerancia por no saber establecer un dialogo, hay resentimiento y rencor. Hay personas que son expertas en algo pero no lo quieren hacer nada por iniciativa propia.

b) Las fortalezas están en que son responsables en su trabajo, trabajo que ellos tienen asignado hacen buen uso de los cursos de capacitación para su desempeño, esto ocurre en la mayoría de los casos porque hay también personas que tienen mucha iniciativa y quieren hacer las cosas pero no saben como, ahi veo que la capacitación es muy importante, la capacitación es básica para la operación del trabajo. Entre las debilidades entre otras, es la frecuente aparición de conflictos estos son más viscerales (emocionales) que cerebrales (lógicos), otra debilidad es la dificultad de la comunicación que repercute en las relaciones humanas, se puede observar que varias enfermeras trabajan de manera individual no les gusta trabajar en equipo, esto creo que en algún momento se rompieron las buenas intenciones, a veces por situaciones que no fueron aclaradas y hacen que se aislen. También se observa este fenómeno en los diferentes departamentos, la escasa comunicación. La escasez de personal causa conflicto y malas relaciones humanas teniendo un ambiente estresante. Existe también escasez de material y equipo ocasiona tensión por todo lo que repercute al brindar servicios.

c) En cuanto ha las fortalezas, es un personal inquieto, con deseos de superación, son personas trabajadoras, bien uniformadas. En cuanto a las debilidades existen conflicto entre ellas y nunca se ponen de acuerdo para llegar a los acuerdos de grupo. La antigüedad para algunas enfermeras las ha hecho conformistas, poco se interesan por lo que pasa en el 
interior del hospital dicen que no les interesa pues no tiene nada que ver con su servicio, algunas colegas no les gusta asistir a cursos de capacitación mencionan que si se les va a aumentar el sueldo si les interesaría pero eso no puede ser, por lo mismo no asisten.

d) El personal tiene puntos fuerte y otros débiles. Los fuertes es que son seres humanos con ilusiones, un grupo pequeño tiene deseos de trabajar algunos desean aprender muevas cosas, para ascender, les gusta asistir a cursos programados en el hospital, les gusta participar en actividades del hospital de tipo social político, religioso entre otros. Los puntos débiles son entre otros que hay personas cansadas, poco interesado en los acontecimientos del hospital aunque tienen mucha experiencia ya no quieren colaborar más. Hacen lo mínimo en sus funciones, existen conflictos originadas por la escasa comunicación entre ellos, quieren sacar todas las prestaciones a su favor y presionan al jefe para lograrlo, a veces amenazan con faltar a su trabajo en los días más complicados de trabajo.

e) En relación a las fortalezas es un personal noble, responsable sabe sus funciones no tenemos que estar inspeccionando a nadie por sus responsabilidades saben trabajar en equipo. Les gusta superarse, estar al día de los avances de los tratamientos y técnicas de avanzada, les gusta la convivencia se reúnen para festejos religiosos o sociales. En cuanto a sus debilidades, es como todo grupo humano tienen altas y bajas a veces surgen conflictos internos y hace que intervengamos, un alto porcentaje de personal esta a punto de cumplir los años para jubilarse esto hace que algunos se sientan cansados y poco satisfechos en sus funciones y no les interesa prepararse o progresar. Otros se amparan con las prestaciones del sindicato y esto hace que se duplique el trabajo, hay poca coordinación entre autoridades del sindicato y las del hospital.

f) En cuanto a sus fortalezas creo que hay personas muy responsables que no necesitan jefe, son responsables saben lo que se debe hacer tienen mucha experiencia y se pude aprender de ellas, otras son jóvenes tienen interés en saber hacer bien los cuidados de enfermería y solicitan asistir a cursos de capacitación. Gracias a ese personal el hospital se sostiene. Sus debilidades de algunas trabajadoras es que desean más prestaciones más derechos que obligaciones y eso es complicado porque no se les pude otorgar todo y se molestan y causan conflicto en el ambiente laboral. Existe resistencia de algunas enfermeras para capacitarse y no desean asistir a cursos por el mismo salario, no existe en su mente que es su obligación, pues vivimos en la cultura de la calidad en donde la mejora continua es siempre. Eso por mencionar algunos problemas

g) El personal de enfermería es muy trabajador, responsable conoce su trabajo tiene mucha experiencia muchos no necesitan supervisión solo me buscan cuando se les ofrece algo serio que sólo yo se los puedo tramitar. Dentro de sus debilidades es personal muy cansado en su mayoría y ya no quieren actualizarse, y la atención médica esta avanzando día a día y requiere de que estén preparadas. A veces la comunicación no es muy fluida teniendo como consecuencia malos entendidos lo que causa conflictos internos, hay escasez de personal eso hace que las cargas de trabajo sean mayores ocasionando un estrés frecuente.

h) Es muy dificil irse sobre un calificativo para todos, hay personas muy responsables pero otras requieren de supervisión constante en una organización hay todo tipo de personal, ha quienes desean hacer las cosas pero no saben y otras no quieren y saben. En una organización como el hospital es muy complejo el comportamiento de las personas. 


\section{4). ¿En su percepción como repercute en su persona el ambiente laboral de las organizaciones hospitalarias de la Secretaria de Salud del D. F.?}

a) El ambiente tiene una combinación de varias actitudes, hay un ambiente altamente normativo que no se puede salir de él, eso me causa angustia debo tener siempre presente el no violar las normas para evitar conflictos con los de arriba y con el sindicato de los trabajadores, o sea cuidar el reglamento en todos los sentidos, aunque mis jefes son gente abierta que se esta superando eso lo hace el ambiente laboral un poco tranquilo, y con esta actitud se puede dialogar. Sin embargo ellas están en una estructura administrativa hegemónica que es la médica independientemente del avance de la enfermería todavía estamos sujetos a la hegemonía medica ellos son los que dictan las políticas, directrices y eso hace un ambiente estresante a veces no son tanto los problemas de enfermería como los médicos ejemplo a la enfermera no se le tiene que estar recordando lo que le debe hacer al paciente sabe enfermería su trabajo, en cambio el médico se le tiene que andar persiguiendo para poner las notas medicas, no hay esa parte de compromiso del médico con el paciente ni con el equipo de trabajo lo tienen, a veces ni atienden a los pacientes por iniciativa se les tiene que andar recordando. Otro problema del ambiente es el servicio de limpieza hay poco estimulo para ellos en su trabajo, aunque hay algunos estímulos no los consideran suficientes para estar motivados, esto causa incomodidad en el trabajo. En la noche hay mayor ausentismo que en los demás turnos a pesar de existir teóricamente la planeación hay imponderables que se presentan para que alguien falte, en estos casos la supervisión es benevolente y solo hacen las tareas necesarias. A mi parece muy interesante el papel del líder en esta carrera me llena de satisfacción lo que hago lo disfruto a pesar de todo el estrés que se vive poder colaborar con mis compañeros me siento autorrealizada con la profesión.

b) El ambiente laboral esta rodeado de muchas reglas como consecuencia de llenado de papeles, esto es más importante que las acciones en la operación para el paciente esto hace que la institución baje su imagen por falta de atención, o como jefe me siento imposibilitada en muchas cosas del hospital pues no depende de mi me siento frustrada porque lo quiero hacer pero no hay con que hacerlo. Sin embargo hago lo que puedo en función de eso es como he venido trabajando. Este tipo de ambiente me hace sentirme incompetente, frustrada me siento altamente estresada por ver los problemas y no poder incidir en su solución. La parte que agobia también, es el centralismo tan marcado piden información con mucha frecuencia y con ciertos requisitos y en un tiempo corto. El espacio fisico donde laboro no reúne las condiciones mínimas de higiene y seguridad el argumento es la escasez de recursos financieros. Esto me deprime aún más. Existe la promesa que se pasará a un espacio propio ya que este es improvisado y por lo tanto no reúne las mínimas condiciones, esperaré con paciencia ese día.

c) En el hospital se deben cumplir paso a paso todas las instrucciones normadas $e$ improvisar equipos para dar atención de enfermería pues en la mayoría de las áreas hospitalarias carecen de lo elemental (medicamentos, ropa, material, otros), eso me preocupa todos los días y cada vez llegan más paciente y no sabemos como los vamos a atender el directo establece las relaciones públicas externas, pero le contestan en el nivel central que por el momento se debe trabajar con lo que se tiene. Estamos viviendo el inicio de un sexenio y eso nos causa confusión en la toma de decisiones pera los problemas de salud. Debemos esperar un poco. Este periodo me causa estrés y angustia me siento frustrada por lo que pasa en mi hospital sin poder hacer casi nada todo es en parte política. 
d) La cobertura de servicios cada vez es mayor y la oferta del hospital es menor esto nos angustia, además los problemas de salud cada vez son más complejos y no se tienen los recursos para satisfacer todas las necesidades de la población esto nos causa problemas de relaciones humanas, poca satisfacción en el trabajo el ambiente es pesado. Yo en particular me siento muy comprometida con el servicio de enfermería y percibo al personal estresado por lo antes descrito. Es posible que sea temporal pues estamos en inicio de sexenio y esto repercute en los hospitales ya que son parte del entorno social.

e) El ambiente laboral es bueno, hay respeto y confianza entre los colegas y en toda la organización del hospital, se viven ciertos apuros como la escasez de recursos humanos, materiales tecnológicos. En mi persona vivo con tranquilidad y tengo las mismas apuraciones de los jefes por la escasez de recursos y la demanda de trabajo, pero que gano con angustiarme sola si yo no lo puedo resolver se hace lo que se puede.

f) El ambiente de un hospital siempre es estresante pues se trabaja con la vida la muerte. En el hospital hacen falta recursos como me toca administrarlos me causa una sensación de impotencia porque al personal no se le puede dar todo. Además vivimos una administración centralizada eso hace que nos pidan a cada momento información que muchas veces no se tienen a la mano y se tiene que cumplir y así otras exigencias. El ambiente es altamente burocratizado eso me causa intranquilidad.

g) El ambiente es muy normativo por lo que siempre se tienen que tener presentes las normas los reglamentos para el buen funcionamiento del hospital, la evaluación es la constante esto nos causa frecuente angustia, por cumplir las metas, las tareas. Nos ocasiona frecuente presión, siempre ha prisa por todo, se termina el día con mucho cansancio.

h) El ambiente de un hospital es complejo por la variedad de servicios y especialidades esto lo hace único y yo me siento a gusto pero no dejo de sentir angustia todos los días porque todo salga bien pues no depende sólo de mi cuidado sino de una serie de circunstancias del ambiente. 
Anexo

Parecer do Comitê de Bioética da Faculdade de Enfermagem

e Obstetrícia de Celaya, Guanajuato

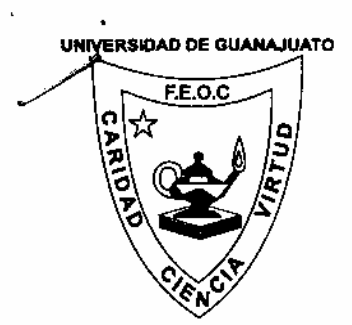

\section{FACULTAD DE ENFERMERLA Y OBSTETRICIA DE CELAYA}

Mutualismo No. 303 Apdo. Postal 91 Celaya, Gto. P/Fax (461) 6153648 y 6153665

Celaya, Gto, 20 de Febrero de 2006

MC. María Alberta García Jiménez

Presente.

Por este conducto, me permito comunicarle que el Comitè de Bicética realizó la primer revisión y evaluación de su protocolo de investigación titulado: "El Liderazgo de Enfermerla en las Organizaciones de Salud de la Ciudad de México, D. F.", el Comité dictaminó que se aprueba

Los miembros del Comité de Bioética la felicitan por la definición y precisión con que ha presentado su proyecto de investigación

Sin otro particular, reciba un cordial sailuḍo

r

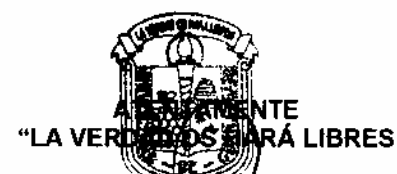

JNERSIDAEIDE GJANAJUATO

Facultad de Entern erif y phot de Celaya

MTRA. ROSAL (AUt II GUERRERO

PRESIDENTA DELI " HE DE BIOÉTICA

FACULTAD DE ENFERMEK AOBSTETRICIA DE CELAYA



PSIC. ELISA GUERBAR RERNANDEZ

SECRETARIA DEL dOMITE DE BIOÉTICA

FACULTAD DE ENFERMERIA Y OBSTETRICIA DE CELAYA

C/2 anexos.

C.c.p. Mtra Maria de Lourdes Garcia Campos_-Coordinadota de Investigación FEOC.

C.c.p. Dra Leticia Cacique Cacique _Coordinadora del Doctorado de la FEOC.

C.c.p. Archivo.

comm. 